\title{
Slovenska znanost
}

Akademska igra

ali adut družbenega napredka?

Franci Demšar

Jasna Kontler - Salamon 

Slovenska znanost 
Znanstvene monografije

Fakultete za management

\section{Glavni urednik}

Matjaž Novak

Uredniški odbor

Ana Arzenšek

Štefan Bojnec

Dubravka Celinšek

Armand Faganel

Viktorija Florjančič

Borut Kodrič

Suzana Laporšek

Mirko Markič

Franko Milost

Matjaž Nahtigal

Mitja Ruzzier

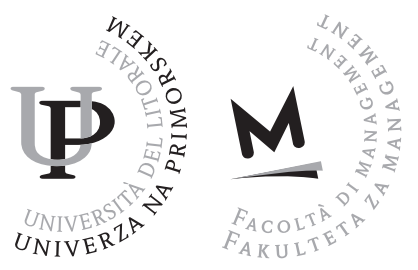

Izid je finančno podprla Fakulteta za management Univerze na Primorskem

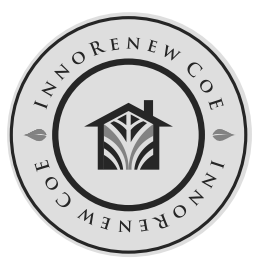

Izid knjige je finančno podprl raziskovalni inštitut InnoRenew Coe Center odličnosti za raziskave in inovacije na področju obnovljivih materialov in zdravega bivanjskega okolja oziroma Okvirni program Evropske Unije, Obzorje 2020 (H 2020 WI DE S P RE A D-2-Teaming; \#739574). 


\section{Slovenska znanost}

Akademska igra ali adut družbenega napredka

Franci Demšar

Jasna Kontler - Salamon 
Slovenska znanost:

akademska igra ali adut družbenega napredka

Franci Demšar

Jasna Kontler - Salamon

Uredila $\cdot$ Julija Uršič

Recenzent · Primož Južnič

Risbe, oblikovanje in tehnična ureditev · Alen Ježovnik

Izdala in založila $\cdot$ Založba Univerze na Primorskem

Titov trg 4, 60oo Koper

www.hippocampus.si

Glavni urednik · Jonatan Vinkler

Vodja založbe · Alen Ježovnik

Koper $\cdot 2020$

(C) 2020 Franci Demšar in Jasna Kontler - Salamon

Elektronska izdaja

http://www.hippocampus.si/ISBN/978-961-7023-27-5.pdf

http://www.hippocampus.si/ISBN/978-961-7023-28-2/index.html

https://doi.org/10.26493/978-961-7023-27-5

(cc) BY-SA

Kataložni zapis o publikaciji (C IP) pripravili

v Narodni in univerzitetni knjižnici v Ljubljani

COBIS S.S I-I $\mathrm{D}=15623683$

IS B N 978-961-7023-27-5 (pdf)

IS B N 978-961-7023-28-2 (html) 


\section{Kazalo}

Seznam slik in preglednic $\cdot 7$

Uvod $\cdot 9$

Glavni mejniki slovenske znanosti do druge svetovne vojne $\cdot 11$

1 Obdobje po drugi svetovni vojni -

kje je bila slovenska znanost leta 1991? $\cdot 23$

Slovenski znanstveniki za mednarodno razumevanje in priznanje Slovenije $\cdot 28$

2 Kateri so glavni mejniki v slovenski znanosti po letu 1991? · 31

$V$ znanosti smo $v$ Evropi $\cdot 41$

3 Vlaganja v raziskave in razvoj $\cdot 43$

Doktorji znanosti gredo drugam $\cdot 43$

Proračuni za znanost $\cdot 46$

Znanost čaka in zbira obljube $\cdot 50$

Poslovni sektor $\cdot 51$

Razvojni vrtičkarji $\cdot 54$

4 Oblike financiranja znanosti $\cdot 57$

Lobiji hočejo svoja "polja» $\cdot 58$

Projekti in tekmovalnost $\cdot 59$

Nepotrjena znanstvena odličnost $\cdot 62$

Programi in stabilnost financiranja $\cdot 63$

Sklepni dan Hevreke: Trideset najodličnejših $\cdot 67$

Mladi raziskovalci $\cdot 68$

Zmagovitega konja se ne brca $\cdot 70$

Raziskovalna oprema in druga področja financiranja $\cdot 72$

Gospodarsko raziskovalno partnerstvo se splača $\cdot 74$

Ocenjevalni postopki $\cdot 75$

Zgrešeno programsko financiranje $\cdot 78$

Spodbujanje sodelovanja z gospodarstvom in drugimi deli družbe $\cdot 81$

Znanost mora tvegati $\cdot 82$

\section{Znanstvena odličnost $\cdot 85$}

Zmagovita enačba? $\cdot 88$ 


\section{Slovenski inovacijski sistem · 91}

Kdaj naš prevod finske pravljice? · 92

Vloga znanstvene in tehnološke politike $\cdot 95$

Lepa nevesta ali dota? $\cdot 98$

Umestitev raziskav in razvoja v širši družbeni kontekst · 99

Cena zapostavljanja družbenih ved $\cdot 101$

\section{Univerze/inštituti $\mathbf{1 0 7}$}

Raziskovalce zdaj menda vabijo tudi tja, kjer jih prej niso marali $\cdot 113$

Mednarodna usmeritev $\cdot 116$

Dvorezna Busquinova zapuščina $\cdot 120$

Transparentnost $\cdot 122$

Tudi $v$ znanosti ni vse javno $\cdot 129$

\section{Avtonomija $\cdot 133$}

Usodno združevanje 137

Enakopravna obravnava vseh in enakopravnost spolov $\cdot 138$

Ženske prihajajo - mar res? 139

Etični standardi in poštenost $\cdot 141$

Pod žarometom: akademik Jože Toporišič $\cdot 142$

Slovenski jezik $\cdot 143$

Kriza temeljnih vrednot $\cdot 145$

\section{Pogled v prihodnost $\cdot 149$}

Bi morala znanost iz EU? 149

Strategije $\cdot 150$

NRRP kot NLP? 152

Kje je Slovenija danes in zakaj bi morale biti znanost in inovacije

bistvo slovenske razvojne strategije $\cdot 155$

Ne dotikaj se moje znanosti $\cdot 156$

Znanost $\cdot 157$

Čas za zmerni optimizem $\cdot 158$

Prenos znanja na študente in $\mathrm{v}$ gospodarstvo $\cdot 160$

Ni modro hujšati možganov, pravijo znanstveniki $\cdot 163$

$\mathrm{V}$ gospodarstvu je še vedno premalo doktorjev znanosti $\cdot 165$

Doktorji znanosti v našem gospodarstvu $\cdot 168$

Zakaj imamo nižji odstotek BDP na prebivalca? $\cdot 170$

Nismo Avstrija. Žal res ne. 170

Zahvale $\cdot 173$

Znanstvena politika od znotraj in s strani

Primož Južnič $\cdot 175$

Pomembnejše okrajšave in kratice $\cdot 185$

Literatura $\cdot 187$ 


\section{Seznam slik in preglednic}

\section{Slike}

3.1 Višina vlaganj v raziskave in razvoj za Slovenijo in E U-28 · 44

3.2 Shematična predstavitev vlaganj v R R pri glavnih deležnikih raziskav in razvoja 44

3.3 Proračunska sredstva, namenjena znanosti (univerzam in inštitutom) za daljše časovno obdobje $\cdot 47$

3.4 Višina vlaganj v raziskave in razvoj v poslovnem sektorju za Slovenijo in E U-28 - 52

3.5 Sredstva, ki jih slovenske univerze in inštituti pridobijo iz gospodarstva $\cdot 54$

4.1 Državna sredstva, namenjena raziskovalnim projektom · 61

4.2 Razmerje med stabilnim in tekmovalnim načinom financiranja za leto $2008 \cdot 66$

4.3 Obseg institucionalnega financiranja v milijonih E U R 67

4.4 Število mladih raziskovalcev po letih od začetka (1985) do leta $2017 \cdot 69$

4.5 Sredstva za raziskovalno opremo v milijonih evrov po petletnih obdobjih $\cdot 73$

5.1 Primerjava citiranosti znanstvenih člankov za Slovenijo in E U-28 iz baze wos $\cdot 86$

5.2 Število najodmevnejših člankov na milijon prebivalcev $\mathrm{V}$ E U in Sloveniji iz baze Scopus $\cdot 86$

5.3 Povprečna citiranost člankov za EU in Slovenijo iz baze WO $\cdot 87$

6.1 Primerjava med B D P na prebivalca in vlaganji v R $\cdot 92$

6.2 Evropski inovacijski indeks (primerjava E U in Slovenije) 95

6.3 Število patentnih prijav (primerjava EU in Slovenije) $\cdot 95$

6.4 Globalni indeks konkurenčnosti (primerjava E U-28 in Slovenije) · 100

6.5 Globalni indeks konkurenčnosti - primerjava tehnološke usposobljenosti v E U-28 in Sloveniji 100

7.1 Razmerje med izdatki za R R v visokošolskem (univerze) in vladnem (inštituti) sektorju v evropskih državah in E U-28 · 109

7.2 Delež financiranja za raziskovanje, namenjen univerzam in raziskovalnim inštitutom $\cdot 111$ 
7.3 Mednarodna sredstva, ki so jih slovenske univerze in inštituti pridobili med letoma 2005 in $2014 \cdot 118$

7.4 Višina pridobljenih sredstev 6. in 7. okvirnega programa glede na vložek države, ki je sorazmeren B D P 119

7.5 Kumulativna rast števila slovenskih člankov v mednarodni bazi WOS 127

9.1 Primerjave vlaganj v znanost in znanstvenih rezultatov, vlaganj poslovnega sektorja $\mathrm{V} R \mathrm{R}$ in rezultatov ter B D P na prebivalca 155

9.2 Delež slovenskih proračunskih izdatkov za znanost glede na E U 158

9.3 Sprememba raziskovalne narave slovenskih univerz z vključitvijo inštitutov v pedagoški proces $\cdot 161$

9.4 Delež slovenskih proračunskih izdatkov za R R v gospodarstvu glede na EU $\cdot 166$

\section{Preglednice}

2.1 Seznam glavnih odločevalcev v slovenski znanosti po letu 1991 · 34

3.1 Predstavitev denarnega toka pri glavnih deležnikih raziskav in razvoja $\cdot 45$

6.1 »Na kaj smo v Sloveniji najbolj ponosni?« Anketni odgovori $\mathrm{v}$ letih 1994, 2003 in $2013 \cdot 101$

8.1 Jezik objavljanja po vedah - primerjava Slovenije in Finske $\cdot 144$ 


\section{Uvod}

Iz kakšnih motivov sva se lotila pisati to knjigo, zakaj naj bi znanosti na ta način pogledala $\mathrm{v}$ obisti?

Franci Demšar: Od nekdaj sem si želel strniti svoje razumevanje delovanja slovenske znanosti in premisliti njegove glavne pomanjkljivosti, hkrati pa predlagati tudi rešitve. Ker je od mojega vodenja ARRS (seznam pomembnejših kratic in okrajšav je na koncu knjige, op. ur.) minilo nekaj let, zdaj to lahko naredim s primerne časovne distance in opozorim tudi na tiste dileme, o katerih v prejšnjih vlogah nisem javno razpravljal, saj sem ocenil, da bi to lahko oviralo njihovo reševanje in zato ne bi bilo konstruktivno. Knjigo torej jemljem kot priložnost, da povem vse, kar bi bilo po mojem mnenju smiselno ukreniti. Ko sem razmišljal o slovenski znanosti, o njenih problemih in izzivih, sem ugotovil, da so pri nekaterih bistvenih stvareh potrebne spremembe, ki se do zdaj še niso zgodile. Te spremembe so večinoma odvisne od odločitev na ministrski ravni.

V knjigi so zajeti mnogi statistični podatki, a ne z namenom, da bi bili predstavljeni celovito. Bralec več podatkov lahko najde v delu Znanstveno raziskovanje $v$ Sloveniji (Sorčan, Demšar in Valenci, 2009), v prispevkih Polone Novak in Stojana Pečlina na spletnih straneh A R S (http: //www.arrs.gov.si) ter na spletnih straneh Eurostata (http://ec.europa .eu/eurostat). Vpogled v izvirne baze podatkov je za primerjavo Slovenije z drugo državo ali skupino držav seveda nujen. Podatke za Slovenijo v knjigi večinoma primerjam s povprečjem E U-28 oziroma jih postavljam v njegov kontekst.

Statistični podatki so zgovorni, a dopuščajo različne interpretacije. Knjiga je zato zasnovana tako, da je najprej predstavljen določen problem, ki ga analiziram jaz, na koncu pa je osvetljen še s komentarji izjemne novinarke Jasne Kontler - Salamon. Njeni komentarji, ki jih je zadnjih 25 let pisala za časopis Delo, se prepletajo s temami posameznih poglavij; širši izbor je naredila avtorica, pri ožjem pa sem sodeloval tudi sam. 
Jasna Kontler - Salamon: Leta 1988 sem prišla v Delovo znanstveno redakcijo in od takrat pa vse do danes (zadnja leta sicer manj intenzivno) spremljam znanstveno dogajanje. Še zlasti me zanimajo vzgibi in akterji slovenske in evropske znanstvene politike. To je bil tudi eden od dveh ključnih razlogov, da sem se odločila za sodelovanje pri tej knjigi. Z navezovanjem na Demšarjev analitični tekst in zaradi časovne distance se iz mojih komentarjev in drugih novinarskih prispevkov namreč lahko izlušči nova sporočilna vrednost.

Drugi razlog za sodelovanje pa je, da dr. Franciju Demšarju zaupam. V letih, ko je kot prvi direktor vodil ARRS, sem pozorno, tudi kritično spremljala delo agencije in s tem tudi Demšarjevo delo. Sicer pa sem ga spoznala že prej, v času kmalu po osamosvojitvi, ko je na resornem ministrstvu delal kot državni sekretar. Dobila sem vtis, da gre za velikega strokovnjaka, ki nikoli ne popušča pritiskom, se prizadevno zavzema za transparentnost in se ne boji spoprijeti z novimi izzivi.

Komentarji Jasne Kontler - Salamon (tudi Jasna Kontler - Venturini in Jasna Kontler), ki so vključeni v knjigo, so bili med 1. februarjem 1991 in 31. majem 2018 objavljeni $v$ dnevniku Delo, večinoma v prilogi Znanost oziroma $v$ njeni predhodnici Znanje za razvoj. V knjigo je poleg njih vključen še apel, prav tako objavljen $v$ Delu, ki ga je minister Peter Tancig naslovil na znanstvenike takoj po osamosvojitvi Slovenije.

Vsi prispevki so objavljeni z dovoljenjem družbe Delo, d. o. o. 


\section{Glavni mejniki slovenske znanosti do druge svetovne vojne}

Knjiga se posveča analizi slovenske znanosti po letu 1991, a preden začnemo z njo, si najprej na kratko poglejmo glavne mejnike, ki so pred tem obeležili razvoj znanosti pri nas. Pregled, ki sledi, je nastal na podlagi knjige Sto slovenskih znanstvenikov Sandija Sitarja (Sitar, 1987) in tako imenovane "srebrne knjige« Science in Slovenia, ki je leta 1994 nastala na pobudo ministra Bohinca, financirala pa jo je Evropska komisija (Zupan idr., 1994). Nekaj podatkov je dopolnjenih s spletnimi informacijami Slovenske biografije (http://www.slovenska-biografija.si/) in Spletnega bibliografskega leksikona znanih Primork in Primorcev (http://www.primorci.si/).

\section{Okoli leta 1000}

- Okoli leta 1000 so nastali Brižinski spomeniki, najstarejši znani zapis v slovenskem jeziku in tudi najstarejši latinični zapis v kakem slovanskem jeziku.

\section{5.-16. stoletje}

Humanizem se je v Sloveniji začel na prelomu 15. stoletja. V prvi polovici 15. stoletja se je pojavila plejada velikih slovenskih mislecev, ki so svoje delo opravljali na evropskih dvorih in univerzah.

- Tomaž Prelokar je bil škof in učitelj mladega Maksimilijana I. Habsburškega (1459-1519), pozneje nemškega kralja in cesarja Svetega rimskega cesarstva.

- Bernard Perger, pedagog, jezikoslovec, pravnik, matematik in astronom ter rektor dunajske univerze in nazadnje kraljevi superintendent na univerzi, je avtor učbenika latinščine z nemškimi komentarji, uspešnice, ki je izšla konec 15. stoletja in doživela trideset izdaj.

- Matija Hvale (Qualle), profesor na dunajski univerzi, je leta 1513 objavil knjigo Commentarii in parvulum philosophiae naturalis - razlago znanosti filozofije, eno temeljnih del takratne filozofije na Dunaju. 
- Andrej Perlah je bil učenjak z enciklopedičnim znanjem, matematik, astronom in zdravnik ter rektor in petkratni dekan dunajske univerze. Med drugim je skonstruiral astronomske inštrumente, ki so mu omogočili opazovanje Merkurja.

- O deželah, ki so bile v prvi polovici 16. stoletja Evropi precej neznane, sta iz prve roke pripovedovala dva diplomata slovenskega porekla. Leta 1531 je Benedikt Kuripečič iz Gornjega grada objavil potopisni dnevnik Potopis potovanja cesarskega poslanstva k turškemu cesarju Sulejmanu leta 1530 o svojem doživetju Turčije. Žiga Herberstein, doma iz Vipave, pa je napisal odmeven potopis o Rusiji Moskovski zapiski (1549), ki je izšel v več izdajah in prevodih.

- Drugi veliki mejnik takratne slovenske znanstvene zgodovine je najdba živega srebra v Idriji leta 1490. Idrijski rudnik se je razvil $\mathrm{v}$ drugi največji rudnik te kovine na svetu, takoj za Almadénom v Španiji. Izkopavanje živega srebra v Idriji, ki je trajalo 500 let, je v Sloveniji pa tudi v Evropi spodbudilo velik razvoj znanosti, medicine in tehnologije. $\mathrm{V}$ prvi polovici 16. stoletja je Idrijo obiskal zdravnik in alkimist Paracelsus. Bil je prvi, ki je začel živo srebro sistematično uporabljati v zdravljenju.

- Santorio Santorio, zdravnik in izumitelj iz Kopra, je konec 16. in na začetku 17. stoletja deloval v Italiji. Uvedel je natančna merjenja v medicini - izumil je tehtnico za merjenje telesne teže in termometer za merjenje telesne temperature, ki ga je izpeljal iz Galilejevega toplomera. Zaradi teorije, ki jo je zasnoval na raziskavah, povezanih z zauživanjem in izločanjem, velja za začetnika moderne fiziologije.

\section{6.-17. stoletje}

Z objavo prvih tiskanih del slovenskih protestantov sredi 16. stoletja (prvo med njimi je bil Katekizem Primoža Trubarja iz leta 1550) se je začelo družbeno, versko in kulturno gibanje, ki mu je kmalu sledila protireformacija.

- Leta 1583 so izobraževanje prevzeli jezuiti. V 17. stoletju so uvedli poglobljen študij teologije, ki mu je na začetku 18. stoletja sledil še študij filozofije in prava. Leta 1688 (ali 1689) je bilo v Ljubljani ustanovljeno prvo znanstveno združenje na slovenskem ozemlju, s čimer se je porodila tudi ideja o ustanovitvi slovenske univerze. 
- Leta 1688 je izšlo monumentalno polihistorsko delo Slava vojvodine kranjske Janeza Vajkarda Valvasorja. Veliki učenjak je v štirih obsežnih in bogato ilustriranih knjigah opisal naravo in življenje večjega dela Slovenije ter okoliških pokrajin in pri tem poskušal zajeti celotno takratno védenje o tem delu Evrope. Njegovo delo, predvsem razlaga delovanja presihajočega Cerkniškega jezera, mu je prineslo članstvo $v$ angleški akademiji znanosti (Royal Society in London).

- Zdravnik Marko Gerbec, pomemben raziskovalec mednarodnega slovesa, je konec 17. stoletja (1693) pripomogel k ustanovitvi prve slovenske znanstvene akademije (Academia Operosorum Labacensium). Cilj akademije je bil, da bi med seboj povezala najustvarjalnejše posameznike v Sloveniji, kar ji je - predvsem na področjih glasbe, arhitekture in umetnosti - tudi uspelo.

\section{8. stoletje}

Ključno vlogo pri napredku slovenske znanosti v času razsvetljenstva je konec 18. stoletja odigral Žiga Zois. Sicer je večina najvidnejših Slovencev v 18. stoletju delovala v tujini.

- Avguštin Hallerstein, matematik, astronom in kartograf iz Mengša, je kot misijonar odšel na Kitajsko in leta 1739 prispel v Peking, kjer je postal predsednik kitajskega matematičnega tribunala, dvorni astronom in mandarin na kitajskem dvoru. Na Kitajskem se je v zgodovino vpisal kot Liu Songling, tako so ga namreč tam poimenovali.

- Žiga Popovič, naravoslovec in jezikoslovec oziroma vsestranski učenjak iz Arclina pri Celju, je veliko potoval, na dunajski univerzi je predaval nemščino in napisal eno temeljnih nemških slovnic, $s$ knjigo Untersuchungen vom Meere (1750) pa oceanografijo utemeljil kot znanstveno panogo.

- Zdravnik Marko Anton Plenčič iz Solkana je deloval na Dunaju in v svojem najpomembnejšem delu Opera medico-physica (1762), ki vsebuje štiri razprave, pravilno domneval, da okužbe lahko povzročajo mikroorganizmi.

- Anton Janša, začetnik modernega čebelarstva, doma z Breznice na Gorenjskem, je študiral na Dunaju in postal prvi cesarsko-kraljevi učitelj čebelarstva. Leta 1771 je objavil knjigo Razprava o rojenju čebel, njegov Popolni nauk o čebelarstvu pa je izšel postumno. Obe de- 
li, ki sta bili prevedeni v več jezikov, sta doživeli številne ponatise.

- Matematik in balistični strokovnjak Jurij Vega, avtor učbenikov za matematiko in fiziko, je eden od utemeljiteljev balistike kot znanstvene discipline. Njegove logaritmične tablice so bile objavljene med letoma 1783 in 1797 in so se kot tehnika računanja uporabljale po vsem svetu vse do uvedbe računalnikov. Po njem je poimenovan udarni krater Vega na Luni.

- Zdravnik in filozof Jožef Peter Alkantara Mislej je z združevanjem matematičnih in filozofskih principov poskušal izdelati matematični model vesolja, ki naj bi poleg snovnih zajemal tudi duhovne kategorije. Njegov univerzalni filozofsko-matematično-teološki sistem je izšel v treh knjigah (1814, 1825 in 1830) na Dunaju.

- Kirurg Vincent Kern, rojen v Gradcu, je deloval v Ljubljani in na Dunaju, kjer je z uvedbo odprtega zdravljenja ran reformiral avstrijsko kirurgijo in vplival na pooperacijsko zdravljenje povsod po Evropi.

- V drugi polovici 18. stoletja sta v Idriji delovala znana zdravnika in naravoslovca Giovanni Antonio Scopoli s Tirolske in Baltazar Hacquet iz Bretanje. Zdravila sta idrijske rudarje, preučevala geološke in ekološke značilnosti rudnika in raziskovala slovenske naravoslovne znamenitosti, svoja spoznanja ter dosežke idrijskega rudnika pa predstavila Evropi.

- S Scopolijem in Hacquetom je sodeloval idrijski zemljemerec, slikar in graditelj Jožef Mrak, znan po klavžah na Idrijci, ki jih je projektiral leta 1772. Mrakove klavže so največje rečne pregrade tako pri nas kot v Evropi, ki so bile namenjene splavljanju lesa in s pomočjo katerih so idrijski rudnik oskrbovali z jamskim podpornim lesom in drvmi. V rudniku je Mrak med drugim izvajal projekt jamomerske in kartografske obdelave, ki ga je zasnoval Franc Anton Steinberg, zemljemerec, kartograf, politehnik, preučevalec Krasa in slikar, doma iz Kalca pri Zagorju na Krasu. Leta 1724 je kot upravitelj idrijskega rudnika začel s temeljitim preučevanjem in posodabljanjem rudnika, kar je rudniku sčasoma prineslo izjemne rezultate in sloves $\mathrm{v}$ Evropi.

- Baron Žiga Zois, naravoslovec, literat, tehnik, podjetnik in osrednja osebnost slovenskega narodnega preporoda, je kot sponzor in izumitelj pomembno vplival na slovensko kulturno, znanstveno in družbeno krajino. Med drugim je bil glavni podpornik pri posku- 
su prvega slovenskega poleta s toplozračnim balonom leta 1784, le pol leta po prvem takšnem poletu na svetu, ki sta ga izvedla brata Montgolfier. Bil je mentor in mecen intelektualcev, ki so se zbirali pri njemu doma (t.i. Zoisov krožek). Leta 1998 so po Zoisu (na pobudo avtorja te knjige) poimenovali tudi najvišjo slovensko nagrado za znanstvene dosežke.

- Jernej Kopitar, raziskovalec slovanskih jezikov in književnosti, ki je izšel iz Zoisovega kroga, je leta 1809 objavil prvo znanstveno slovnico slovenskega jezika (Grammatik des schlavischen Sprache in Krain, Kärnten und Steiermark), ki je obveljala za eno najvplivnejših slovanskih tovrstnih del.

\section{9. stoletje}

Čas Ilirskih provinc (1809-1813), ko je večina slovenskega ozemlja prišla pod francosko jurisdikcijo, Ljubljana pa je postala glavno mesto, je bil prekratek, da bi se lahko izpeljali ambiciozni načrti za reorganizacijo šlstva in ustanovitev univerze. Sledilo je obdobje, v katerem so po vsej Evropi prevladovale reakcionarne tendence.

- Drugi kongres Svete alianse je potekal leta $1821 \mathrm{v}$ Ljubljani, ki je s tem za kratek čas postala center Evrope. Na njem so sklenili zatreti revolucijska vrenja po Evropi.

- Na začetku 19. stoletja je Slovenijo močno zaznamovala uvedba parnih strojev. Leta 1818 je iz Trsta v Benetke izplul prvi parnik v Jadranskem morju, leto pozneje pa so $\mathrm{v}$ Trstu postavili parni mlin, prvi stroj na parni pogon na Slovenskem. Naslednjega zasledimo leta $1835 \mathrm{v}$ Ljubljani, kmalu za tem pa še v rudniku živega srebra v Idriji.

- Josef Ressel, gozdar in izumitelj češko-nemškega rodu, je kot gozdar v Sloveniji, kamor je prišel leta 1817, uvajal napredno gospodarjenje in razvijal idejo ladijskega vijaka. Patentiral ga je leta 1827 in ga dve leti pozneje najprej demonstriral na Seni v Parizu, tu še na ročni pogon, zatem pa istega leta $v$ Trstu še na parni pogon.

- Uporaba strojev na parni pogon je v Sloveniji dosegla višek med letoma 1849 in 1857, ko je bila zgrajena železnica Trst-Ljubljana.

- Med pomembne dogodke prve polovice 19. stoletja se je zapisalo tudi odprtje Kranjskega deželnega muzeja (zdaj Narodni muzej Slovenije) leta 1831. 
- Leta 1842 je Kranjčan Janez Puhar izumil fotografijo na steklu. S svojimi fotografijami je sodeloval na razstavah v Londonu in New Yorku in leta 1852 prejel diplomo "izumitelj fotografije na steklu«, ki mu jo je podelila akademija za poljedelstvo, obrt in trgovino $\mathrm{v}$ Parizu.

- Leta 1830 je Friderik Baraga, misijonar, ki je pozneje postal škof, odšel v Ameriko in začel delati med severnoameriškimi Indijanci (Otava in Očipva). Bil je pomemben etnološki in jezikovni raziskovalec. Leta 1837 je objavil pionirsko etnološko delo, študijo o šegah in načinu življenja severnih Indijancev, leta 1850 slovnico očipvejskega jezika, ki je prva slovnica kakega indijanskega jezika sploh, leta 1853 pa še očipvejsko-angleško-očipvejski slovar.

- Baragovo delo je navdihnilo misijonarja in raziskovalca Ignacija Knobleharja, v Afriki znanega pod imenom Abuna Soliman, ki je leta 1848 prišel v Sudan. Med postavljanjem misijonskih postaj je raziskoval porečja Nila. Bil je prvi belec, ki je na Belem Nilu prišel vse do 3. stopinje severne širine, avtor študij o prebivalcih ob Nilu ter pomemben zbiratelj tamkajšnjega etnološkega, zoološkega in botaničnega gradiva.

- Filolog Fran Miklošič, preučevalec slovanskih jezikov, poliglot in utemeljitelj slovanskega primerjalnega jezikoslovja, je bil rektor dunajske univerze, ustanovitelj dunajske stolice za primerjalno slovansko jezikoslovje in večkratni dekan dunajske filozofske fakultete. Njegova mojstrovina, obsežna primerjalna slovnica slovanskih jezikov, je izhajala v letih $1852-1875$, leta 1886 pa je objavil tudi etimološki slovar slovanskih jezikov.

- Češko-avstrijski speleolog in geograf Adolf Schmidl je na pobudo dunajske akademije znanosti v letih 1850-1854 raziskoval slovenski Kras oziroma kraške jame. Objavil je več speleoloških študij o naših krajih, na podlagi katerih je speleologijo (jamoslovje) uveljavil kot novo znanstveno področje.

- V drugi polovici 19. stoletja je Marko Vincenc Lipold, prvi slovenski geolog, rudarski inženir in paleontolog, podrobno preučil geološko sestavo in zgradbo idrijskega rudnika, v tehnologijo rudarjenja pa vpeljal novejša znanstvenogeološka spoznanja. Njegovo tradicijo je po drugi svetovni vojni nadgrajeval geolog Ivan Mlakar, ki je z natančnimi znanstvenimi postopki podaljšal življenjsko dobo ru- 
dnika, $\mathrm{z}$ raziskovanjem rudonosnih območij pa se je ukvarjal tudi po zaprtju rudnika leta 1977. Mlakar je ob sebi zbral sodelavce, ki so njegovo delo nadaljevali in zasloveli kot »idrijska geološka šola«.

- Jožef Stefan, eden najpomembnejših fizikov 19. stoletja, je bil rektor dunajske univerze, direktor fizikalnega inštituta dunajske univerze, dekan dunajske filozofske fakultete, ustanovitelj dunajske šole teoretične fizike in podpredsednik avstrijske akademije znanosti. Leta 1879 je odkril zakon o sevanju črnega telesa, njegov učenec Boltzmann pa je pet let pozneje zakon tudi teoretično izpeljal. Zakon se zato imenuje Stefan-Boltzmannov zakon in je edini fizikalni zakon, ki se imenuje po kakšnem Slovencu. V zadnjih letih svojega življenja se je Stefan posvetil raziskavam na področju elektrotehnike. Bil je med ustanovitelji prvega avstrijskega elektrotehniškega društva in tudi njegov prvi predsednik. S pomočjo najboljših pripomočkov in sodelavcev je razvijal metode merjenj elektrike in s tem prispeval $\mathrm{k}$ nastanku moderne elektrotehniške merilne tehnike. Po njem je poimenovan udarni krater Stefan na Luni.

- Leta 1881, tri leta po Edisonovem izumu žarnice, je na Kongresnem trgu v Ljubljani zagorela prva žarnica v Sloveniji, dve leti pozneje je žarnice dobil še Maribor.

- Edo Šlajmer, po rodu Hrvat, je utemeljitelj moderne kirurgije na Slovenskem. Medicino je študiral v Gradcu in si z operacijami kmalu pridobil mednarodni ugled. Leta 1891 je prišel v Ljubljano in zaslovel kot najboljši kirurg južno od Dunaja. V zdravstvo na Slovenskem je vpeljal spremembe tako $\mathrm{v}$ diagnostiki kot pri operativnih posegih in v pooperacijski negi.

- Leta 1895 je Ljubljano prizadel uničujoč potres, ki je zavrl rastoči napredek. Potresu je sledila obnova, ki nosi pečat modernega oblikovanja arhitekta Maksa Fabianija.

- Dve leti po potresu je naravoslovec, seizmolog in izumitelj Albin Belar v Ljubljani postavil potresno opazovalnico, ki jo je razvil v prvi moderni evropski seizmološki sistem $v$ Evropi, skupaj z japonskimi pa je bil tudi eden najboljših na svetu. Naprave za merjenje potresov, ki jih je imenoval tremometri, je sam izumljal, med drugim tudi prvi prenosni potresomer na svetu. Ljubljana je zaradi njegove dejavnosti postala svetovno središče seizmološke vede. 


\section{0. stoletje do druge svetovne vojne}

Začetek dvajsetega stoletja je močno zaznamovala prva svetovna vojna, kmalu po njej pa je bila ustanovljena Univerza v Ljubljani. V obdobju do začetka druge svetovne vojne je bil to eden od najpomembnejših dogodkov za razvoj slovenske znanosti.

- Leta 1901 je Ljubljana zgradila električno tramvajsko povezavo in tako vstopila v 20. stoletje.

- Izumitelj baron Anton Codelli, ki se je med drugim posvečal avtomobilizmu, je na začetku 2o. stoletja načrtoval rotacijski eksplozijski motor. Bil je tudi prvi, ki je v Ljubljano pripeljal avtomobil. Najbolj se je uveljavil v radijski telegrafiji. Postal je pionir brezžičnega radijskega povezovanja na daljavo, ki ga je razvijal za avstro-ogrsko mornarico in zatem za Nemčijo. Vzporedno je razvijal mehaničnooptični televizijski sistem (patentirati mu ga je uspelo šele leta 1928), s katerim se je uvrstil tudi med pionirje televizije.

- Franc Wels, slovenski izumitelj in letalski pionir iz Maribora, je razvil letalsko krilo, ki posnema obliko letečega rastlinskega semena (alsomitra macrocarpa). Z njim je poletel leta 1906, kar je bil v tedanji Avstro-Ogrski prvi polet $z$ letalno napravo, težjo od zraka, in prvi polet s takšnim letalom na svetu.

- Brata Edvard in Jože Rusjan sta bila letalska pionirja, ki sta po številu zasnovanih, izdelanih in preizkušenih letal segala v svetovni vrh. Edvard Rusjan je leta 1909 prvič poletel z letalom na motorni pogon, kar je bil prvi tovrstni polet na Slovenskem in tudi prvi polet $\mathrm{z}$ letalom domače izdelave $\mathrm{v}$ tem delu Evrope in na Balkanu.

- Ivan Slokar, gospodarstvenik, zgodovinar, jezikoslovec in letalski izumitelj, avtor enotne svetovne pisave, ki jo je imenoval linguografija, je leta 1911 patentiral izum helikopterskega letala $\mathrm{z}$ dvema rotorjema. Takšen helikopter, ki povsem ustreza Slokarjevemu patentu, so tehnično prvič preizkusili šele 25 let pozneje v Nemčiji.

- Leta 1914 je Julij Nardin, pozneje profesor fizike na ljubljanski medicinski fakulteti, kjer je ustanovil fizikalni inštitut in postal tudi njegov prvi vodja, razvijal zamisel za samokrmiljeni torpedo in delal na patentu dvostopenjske rakete. $V$ vodi bi tak projektil postal torpedo na lasten pogon. Nardin je pri svojem raziskovanju prišel tudi do izdelave releja, ki je deloval kot elektronka, in se zapisal med začetnike moderne kibernetike na Slovenskem. 
- Janez Puh, slovenski izumitelj, mehanik in proizvajalec vozil, se je najprej ukvarjal s kolesi in leta 1889 kot prvi na svetu izdelal bicikel z dvema enako velikima kolesoma. Nadaljeval je z motocikli in avtomobili. Svoj prvi avtomobilski model je izdelal že leta 1901, do leta 1914 pa jih je razvil čez deset in z njimi zalagal avstrijski dvor.

- Leta 1919 je bila ustanovljena Univerza v Ljubljani, ki je slovenskim znanstvenikom omogočila, da se izobražujejo in razvijajo v Sloveniji. Med prvimi univerzitetnimi profesorji ljubljanske univerze so bili mednarodno priznani slovenski znanstveniki. Josip Plemelj, eden najpomembnejših matematikov na začetku 20. stoletja in prvi rektor univerze, je zaslovel $\mathrm{z}$ več dosežki, najvidnejši med njimi je iz leta 1906, ko mu je uspelo rešiti Riemannov problem diferencialnih enačb, za kar so si zaman prizadevali številni drugi matematiki. Kemik Maks Samec, utemeljitelj moderne kemijske znanosti na Slovenskem, se je proslavil s preučevanjem škroba in z drugimi dosežki v koloidni kemiji. Prvi Samčev asistent in zatem redni profesor je postal kemik Marius Rebek, ki se je ukvarjal z organsko kemijo, pozneje pa je kot profesor in predstojnik delal na inštitutu za kemijo in tehnologijo papirja in celuloze v Gradcu. Milan Vidmar, strojni inženir, elektrotehnik in šahovski velemojster, je začetnik znanstveno utemeljene elektrotehnike na Slovenskem. Zaradi dosežkov v elektrotehniki, še posebno na področju transformatorjev, je užival svetovni sloves. Jože Plečnik, najpomembnejši slovenski arhitekt, je mednarodno slavo dosegel z deli na Dunaju, v Pragi in v Sloveniji, še posebno v Ljubljani, ki ji je v poznih dvajsetih letih prejšnjega stoletja vtisnil tak pečat, da jo pogosto imenujemo kar Plečnikova Ljubljana.

- Zdravnik in kemik Friderik Pregl, rojen v Ljubljani, je večino časa preživel v Gradcu, kjer je razvil mikroanalizne postopke za organsko kemijo. Za svoje dosežke je leta 1923 prejel Nobelovo nagrado in s tem postal doslej edini nobelovec slovenskega rodu.

- Ivan Regen, zoofiziolog in začetnik znanstvene bioakustike, je konec 19. in v prvi polovici 20. stoletja raziskoval žuželke in njihovo sporazumevanje, še posebej oglašanje murnov, in si v bližini Dunaja uredil prvo geobiološko postajo v Evropi. Kot pionir na področju bioakustike je razvijal tako izvirne metode dela kot eksperimentalne pripomočke, potrebne za raziskave.

- Leta 1933 je bil v Ljubljani zgrajen Nebotičnik, takrat najvišja sta- 
novanjska stavba v Evropi (tudi najvišja železobetonska stavba v Srednji Evropi in na Balkanu ter najvišja stavba v Kraljevini Jugoslaviji). Trinajstnadstropna zgradba, visoka 70,35 metrov, ki jo je projektiral arhitekt Vladimir Šubic, je bila narejena po principih potresno varne gradnje - statik Stanko Dimnik je pri izračunu statike po kompleksnem japonskem modelu upošteval 35-kratni potresni faktor.

- Fran Jesenko, mednarodno uveljavljeni botanik in rastlinski genetik, aktiven v prvi polovici 2o. stoletja, je bil prvi, ki je uspešno križal pšenico ter rž in vzgojil rodne potomce, in prvi, ki je dokazal, da Mendlov zakon genetike velja tudi za rastlinske hibride.

- V obdobju med letoma 1923 in 1925, ko so se glavni tehnološki preboji dogajali v drugih delih sveta, je pomorec in izumitelj Miroslav Štumberger razvijal raketni motor na tekoče gorivo.

- Pionir raketne in vesoljske tehnike Herman Potočnik Noordung je prvi izračunal osnove za postavitev geostacionarnega komunikacijskega satelita in za bivalno vesoljsko postajo. Zaradi svojih idej in izdelanega načrta za prodor v vesolje, ki ga je leta 1929 objavil v knjigi Problem potovanja po vesolju - raketni motor, velja za enega od utemeljiteljev kozmonavtike.

- Med takratnimi raziskovalci sta bila mednarodno priznana tudi Vladimir Šlebinger, elektroinženir, energetik in hidrolog, ki je v letih 1930-1933 na inštitutu Heinricha Hertza sodeloval pri prilagoditvi katodne cevi za televizijo, in slovenski jedrski fizik Elmer Rebolj, ki je sodeloval z Enricom Fermijem, očetom prvega jedrskega reaktorja.

- Tridesetim letom prejšnjega stoletja je dal velik pečat inženir elektrotehnike in strokovnjak za mehaniko Anton Kuhelj, ki je pred drugo svetovno vojno izdelal več uspešnih letal.

- Leta 1938, tik pred drugo svetovno vojno, je bila v Ljubljani ustanovljena Slovenska akademija znanosti in umetnosti (S A ZU). Večina raziskovalnega dela danes poteka preko njenega raziskovalnega centra, ki je bil leta 1991 sestavljen iz 14 inštitutov. Mnogi od inštitutov so poimenovani po najbolj uveljavljenih strokovnjakih za posamezna področje. Inštitut za slovenski jezik je tako poimenovan po Franu Ramovšu, enem od ključnih slovenskih jezikoslovcev, zgodovinski inštitut po Milku Kosu, ki je posvetil osrednji del svojih raziskav izvoru, migracijam in adaptaciji Slovencev v Sloveni- 
ji, umetnostnozgodovinski inštitut po enemu izmed največjih slovenskih umetnostnih zgodovinarjev Francetu Steletu, geografski inštitut po utemeljitelju sodobne geografije in avtorju prve splošne monografije o Sloveniji Antonu Meliku, paleontološki inštitut nosi ime vsestranskega naravoslovca in svetovno priznanega specialista za ledenodobne sesalce Ivana Rakovca, inštitut za biologijo pa zoologa Jovana Hadžija, znanega predvsem po izvirnih teorijah o evoluciji različnih živalskih skupin. 



\section{Obdobje po drugi svetovni vojni - kje je bila slovenska znanost leta 1991?}

Institut »Jožef Stefan«, ki je leta 1949 nastal iz Fizikalnega instituta pri S AZ U (ustanovljenega leta 1946), se je postopoma razvil v največjo slovensko raziskovalno organizacijo po drugi svetovni vojni. Leta 1991 je zaposloval približno tisoč raziskovalcev in drugega osebja ter sledil svetovnim raziskovalnim trendom na vsaj desetih področjih. Zelo aktiven je bil pri mednarodni izmenjavi znanja in raziskovalcev. Veliko slovenskih raziskovalcev $\mathrm{z}$ inštituta je sodelovalo z uveljavljenimi ustanovami v tujini; imeli so mednarodni sloves, med njimi že ustanovitelj inštituta Anton Peterlin, strokovnjak na področju velemolekul in polimerizacije. Inštitut je vzdrževal stike $z$ bivšimi zaposlenimi, ki so delali v tujini. Raziskovalci oddelka za biokemijo, ki jih je takrat vodil Vito Turk, so ime inštituta uporabili za poimenovanje nove substance - stefin (cistatinski inhibitor) -, ki so jo izolirali iz človeške krvi.

Drugi največji naravoslovni inštitut je bil Kemijski inštitut (takrat poimenovan po Borisu Kidriču), ki ga je ustanovil Maks Samec, sicer član prve ekipe profesorjev na ljubljanski univerzi, najprepoznavnejši raziskovalec inštituta pa je bil Dušan Hadži, svetovno znan po raziskavah vodikove vezi. Na področju kemije je treba omeniti še kemijski center, pridružen ljubljanski univerzi, ki je pridobil status Unescovega centra za kemijske študije, vodila pa ga je Aleksandra Kornhauser.

Med najrazvitejša znanstvena področja v Sloveniji je leta 1991 spadala fizika. Delo Roberta Blinca na področjih fizike trdne snovi, feroelektrikov in jedrske magnetne resonance je bilo v središču raziskovalnih aktivnosti Instituta »Jožef Stefan«. Številni slovenski fiziki pa so se uveljavljali v tujini. Savo Bratož (Pariz) je bil zelo prodoren v raziskavah molekularnega gibanja v tekočinah, Bibijana Čujec (Kanada) in Dušan Povh (Nemčija) sta se pri raziskovanju elementarnih delcev ukvarjala s problemi antimaterije. Dva slovenska znanstvenika sta bila pomembna sodelavca vesoljske agencije N A A: vrhunski fizik nizkih temperatur Dušan Petrič in elektrotehnik Anton Mavretič, ki je delal na elektronskih sistemih za detektorje na vesoljskih sondah. Ciril Pipan (ZDA) je 
najprej delal kot raziskovalec na področju elektrooptike (periskopi za polarne podmornice), potem pa je organiziral raziskovanje laserjev za vesoljski program. Prodornih slovenskih znanstvenikov in intelektualcev je bilo v tujini seveda še več, o čemer ne nazadnje priča tudi delo Jožeta (Josepha) Velikonje Who's Who of Slovene Descent in the United States (Velikonja in Lenček, 1995).

Slovenija je imela leta 1991 tudi odlične raziskovalce na področju kemije, med njimi Davorina Dolarja na področju ionskih izmenjav in polielektrolitov, Miha Tišlerja na področju sinteze novih, pretežno heterocikličnih organskih spojin in Marka Zlokarnika (Nemčija), čigar raziskovanje pri nemškem podjetju Bayer AG je odpiralo znatne možnosti učinkovitih ekoloških rešitev pri čiščenju odpadnih voda.

Širok nabor raziskovalcev je deloval $\mathrm{v}$ tehniških znanostih. Na področju kibernetike je Janez Peklenik razvil koncept decentraliziranih ter visoko avtomatiziranih in fleksibilno povezanih stanovanjskih enot. Raziskovalec na področju elektronike in biokibernetike Lojze Vodovnik je razvil osnovo za učinkovito električno stimulacijo z vrsto aplikacij, posebej uporabnih v medicini. Aleš Strojnik je eden od tistih vrhunskih ekspertov, ki doma niso našli pravih priložnosti in so uspeli v tujini. Strojnik je kot raziskovalec na področju elektronske mikroskopije in $\mathrm{z}$ njo povezane letalske industrije deloval v Z DA.

Na področju raziskav v medicini je Slovenija prav tako dosegala mednarodno priznane rezultate, na primer pri preučevanju prenosa signalov po živcu, kjer sta do pomembnih odkritij prišla Andrej O. Župančič in Miroslav Brzin, oba z Inštituta za patološko fiziologijo v Ljubljani. Najvidnejši slovenski znanstvenik na področju medicine je bil v tem času Joseph Milič - Emili, raziskovalec na področju fiziologije in mehanike dihanja, ki se uvršča med 1000 najbolj citiranih svetovnih raziskovalcev. Znanstveno raziskovanje Marije Us - Krašovec, pri katerem je sodelovala s kolegi v tujini, je pripeljalo do razvoja in široke uporabe nove metode za hitro in nebolečo diagnozo raka. Miro Košak, srčni kirurg in utemeljitelj kardiovaskularne kirurgije v Sloveniji, je prvi na svetu izvedel avtotransplantacijo srca, Marku Godini, specialistu za plastično kirurgijo, pa je leta 1984 prvemu na svetu uspelo ponovno uspešno pritrditi odtrgano roko. Igor Mekjevič je med tistimi znanstveniki, ki so si ugled pridobili najprej v tujini, in sicer v Kanadi, kjer je prišel do zanimivih rezultatov pri študiju učinkov povečanega zračnega pritiska, nato pa je $\mathrm{v}$ domovini vpeljal hiperbarične komore in $\mathrm{s}$ tem pripomogel $\mathrm{k}$ razvoju novega področja medicine. Podoben je primer Berte Jereb, ki je ena od 
začetnic otroške onkologije v svetu in se je po daljšem bivanju v Z DA in na Švedskem vrnila domov.

Pomembne so bile raziskave tudi na drugih področjih, denimo v psihiatriji, kjer se je Lev Milčinski med drugim posvečal problematiki samomorilnosti. Psiholog Anton Trstenjak se je ukvarjal s širokim spektrom psiholoških tematik in raziskoval na področjih tako klinične kot eksperimentalne psihologije ter psihologije ustvarjalnosti. Veliko uveljavljenih raziskovalcev se je posvečalo študijem slovenske literature in jezika, najvidnejši predstavnik tega področja je bil jezikoslovec Jože Toporišič. Na področju zgodovine je Bogo Grafenauer sprožil živahno debato o izvoru Slovanov. V teologiji se je Jože Krašovec usmeril v raziskave etike človeških odločitev. Ekonomist Aleksander Bajt je sodeloval pri raziskovanju ekonomskih predvidevanj in postavil temelje kvantitativni metodi ekonomske analize.

Slovenska znanost po drugi svetovni vojni se je torej pospešeno razvijala, o njenih akterjih pa lahko več izveste, denimo, iz pogovorov z njimi v knjigi Strast po znanju in spoznavanju dr. Edvarda Kobala (Kobal, 2003). Znanstveno dogajanje v obdobju slovenskega osamosvajanja je bilo bogato in živahno, številni slovenski znanstveniki z različnih področij pa prodorni in tudi mednarodno uveljavljeni. Eden od razlogov za to je tudi znatno število znanstvenih ustanov, ki so nastale $\mathrm{v}$ času do leta 1991. Prva, Univerza v Ljubljani, je bila ustanovljena leta 1919, leta 1938 ji je sledila SAZU in leta 1975 Univerza v Mariboru. Po drugi svetovni vojni smo dobili Institut »Jožef Stefan«, Znanstvenoraziskovalni center S AZU in Kemijski inštitut ter leta 1990 Nacionalni inštitut za biologijo, delovalo pa je tudi preko trideset manjših inštitutov. Velik raziskovalni potencial je imel Univerzitetni klinični center v Ljubljani, ki je bil zgrajen leta 1975 .

Šifrant raziskovalnih področij slovenske znanosti iz leta 1991 prikazuje njihovo veliko razvejanost: naravoslovno-matematične vede (matematika, informacijski sistem in programiranje, astronomija, geofizika, kemija, biologija, geologija in mineralogija, fizikalna geografija, fizika), tehniške vede (rudarstvo, črna metalurgija, barvna metalurgija, uporabna geologija in uporabna geofizika, elektrotehnika, elektronika in avtomatika, strojništvo z ladjedelništvom, gradbeništvo, geodezija, arhitektura, živilska tehnologija, tekstilna tehnologija, kemijska tehnologija, transport), medicinske vede (medicina, stomatologija, farmacija), biotehniške vede (poljedelstvo, sadjarstvo, vinogradništvo, gozdarstvo in hortikultura, živinoreja, ribolov, veterinarstvo), družboslovne 
vede (antropologija, ekonomske vede, pravne vede, politične vede, organizacijske vede, sociologija, psihologija, lingvistika, izobraževanje, demografija, družbena geografija), humanistične vede (filozofija, zgodovinske vede, vede o jeziku in književnosti, umetnostne vede, etnologija in etnografija, telesnokulturne vede).

$\mathrm{Ob}$ vsem tem je slovenska znanost premogla kar nekaj velike in zahtevne raziskovalne opreme, kot so reaktor T R I G A, Van de Graaffov pospeševalnik, jedrski magnetnoresonančni (N M R) spektrometri visoke ločljivosti, masni spektrometri visoke ločljivosti, magnetnoresonančni (MR) tomografi, naprave za analizo mikrostrukture in površine, računalniki z veliko zmogljivostjo, CAD sistemi, naprave za študij genetskega inženiringa, molekularne biologije, biokemije in biotehnologije.

Kot kaže slika proračunskega financiranja (slika 3.3 na strani 47), smo v osemdesetih letih prejšnjega stoletja skoraj podvojili proračunska vlaganja v znanost. Glede na odstotke BDP, namenjene znanosti, smo s tem nekaj let pred in nekaj let po 1991 presegali evropsko povprečje vlaganja v znanost. Največ dodatnih sredstev je bilo namenjenih novi obliki financiranja podiplomskega študija - mladim raziskovalcem - ter nabavi raziskovalne opreme in novemu raziskovalnemu področju molekularne biologije. Razmerje med financiranjem inštitutov in univerz je bilo 60 : 40 odstotkov v korist inštitutov. Glavni financer znanosti pred letom 1991 je bila RS s, ki je delovala od leta 1971 (njen predhodnik, Sklad Borisa Kidriča, pa od leta 1953). Financiranje znanosti je potekalo prek dveh instrumentov stabilnega financiranja: Usmerjenega raziskovalnega programa (URP) za temeljne raziskave (70\%) in Posebnih raziskovalnih skupnosti (PORS) za aplikativne raziskave (30\%).

Toda če se ozremo na mednarodno primerljive indikatorje znanstvene odličnosti, ugotovimo, da je bila raven znanstvenih objav skromna, glede na članke, ki jih obravnava wos, je dosegala le polovico evropskega povprečja, glede na mednarodno odmevnost - število citatov na milijon prebivalcev - pa še manj, komaj tretjino evropskega povprečja. Tudi povprečna citiranost del (citati na članek) kaže na njihovo slabo odmevnost, saj smo tudi tu dosegli le polovico evropskega povprečja. $\mathrm{Pa}$ vendar lahko rečemo, da takratna slovenska znanost nikakor ni sodila med neurejena področja, nasprotno, bila je na presenetljivo visoki ravni. Po merilih znanstvene odličnosti je krepko prednjačila pred drugimi novimi kandidatkami za članstvo v E U. Po citiranosti naših člankov smo dosegli dvakrat boljši rezultat kot vzhodnoevropske, res pa tudi polovico slabšega kot sredozemske države. Leta 1992 s polovice slovenskih 
raziskovalnih področij ni bil objavljen niti en članek v zgornji četrtini najkakovostnejših revij $\left(A^{\prime}\right)$ in enako velja tudi za raziskovalne organizacije - polovica med njimi ni imela ene same objave v kategoriji $\mathrm{A}^{\prime}$ (po podatkih Sicrisa, http://www.sicris.si). Imeli smo torej skupine, ki so bile zelo dobre (Institut "Jožef Stefan", skupine na univerzah), hkrati pa ogromno področij, kjer mednarodno primerljive znanstvene kakovosti ni bilo.

Deleža raziskav in razvoja v gospodarstvu ter sodelovanja med gospodarstvom in znanostjo sta, tako kot sama znanost, ob nastanku slovenske države dosegala približno polovico evropskega povprečja; to velja za neposredno spodbujanje razvoja $v$ gospodarstvu $v$ obliki državnih subvencij in za delež, namenjen raziskavam in razvoju v gospodarstvu. R S je s programom PORS vzpostavila sistem, preko katerega je financirala znanost, ki jo je obenem sofinanciralo gospodarstvo; podoben sistem so aplikativni projekti, ki jih je zatem razvilo ministrstvo za znanost in jih danes razpisuje ARRS.

Gospodarstvo je imelo takrat kakovostna razvojna jedra. Tu bi veljalo posebej omeniti Iskro, ki je zaposlovala velik del slovenske tehnične inteligence, vendar sistem žal ni obstal. Izjemen vzpon in potem hiter propad je doživela Iskra Delta, v osemdesetih letih prejšnjega stoletja največji evropski proizvajalec osebnih računalnikov, pomemben izvoznik v Sovjetsko zvezo in investitor na Kitajskem (Škrubej, 2013). Po podatkih iz leta 1993 je bilo v slovenskem gospodarstvu zaposlenih 50 doktorjev znanosti, kar je pomenilo tri odstotke vseh doktorjev znanosti. Sredstva za raziskave in razvoj so v celoti štela 184 milijonov dolarjev, od tega je bilo 45 odstotkov namenjenih vlaganju $\mathrm{v}$ raziskave $\mathrm{v}$ gospodarstvu (Komac, Bavec, Penca, Vrenko, Semolič in Godina, 1994).

$\mathrm{Za}$ mednarodno sodelovanje, ki je prineslo sporazume $\mathrm{z}$ mnogimi državami, je od začetka osemdesetih let skrbela ustanova ZAMTES. Posebej dejavno je bilo sodelovanje $z$ agencijami OZN (UNDP, UNIDO, WHO, UNESCO, IAEA), z nekaterimi mednarodnimi organizacijami (TEMPUS, PHARE, COST, EUREKA), regionalnimi organizacijami (Alpe Jadran, CEI) in mednarodnimi centri (CERN, ICGEB, ICTP), živahno znanstveno sodelovanje je potekalo $\mathrm{z}$ evropskimi državami, kot so Nemčija, Francija, Velika Britanija, Avstrija, pa tudi z neevropskimi, predvsem z Z D A, Japonsko in Avstralijo.

RSS je v znanosti uveljavila visoko stopnjo avtonomije pa tudi transparentnosti, saj je od leta 1954 letno objavljala podrobna finančna poročila o porabi sredstev za znanstveno dejavnost. Delovale so pomemb- 
ne infrastrukturne ustanove, kot sta A R N E S (takrat Yunac), ki je Sloveniji omogočal mednarodne internetne povezave, takrat sicer prisotne le v akademskem svetu, in I ZU M (takrat RCU M), ki je vzpostavil integriran knjižnično-informacijski sistem сов IS S (takrat Jubib) in ga povezal z bibliografijami raziskovalcev. Knjižnice imajo v Sloveniji ugledno tradicijo, posebej Narodna univerzitetna knjižnica ( $\mathrm{NU}$ K), ki se ponaša $\mathrm{z}$ več kot 200-letno tradicijo in je leta 1991 sodila med tristo največjih svetovnih knjižnic. Drugi dve pomembni knjižnici sta bili takrat v Sloveniji še Centralna tehniška knjižnica in Univerzitetna knjižnica Maribor, svoje knjižnice pa so imeli tudi raziskovalni inštituti, med njimi je bila posebej obsežna knjižnica Instituta »Jožef Stefan«.

Do leta 1991 se je v slovenski raziskovalni srenji le malo razpravljalo o enakopravnosti spolov ter o etičnih standardih raziskav in pomenu nacionalnega jezika, vendar tudi v drugih evropskih državah ni bilo bistveno drugače.

\section{Slovenski znanstveniki za mednarodno razumevanje in priznanje Slovenije}

Delo, 3. julij 1991

Dostojanstven in odločen odpor prebivalcev Slovenije proti z ničimer izzvani brutalni vojaški agresiji na našo samostojno in neodvisno državo je izredno odmeval v celotnem svetu. Žal je še vedno tako, da se države rojevajo skoraj izključno z vojno in nasiljem, in zato so se možnosti za dosti hitrejše mednarodno priznanje Slovenije zelo povečale.

Javno mnenje $v$ številnih zahodnih državah nam je zelo naklonjeno, do podobnega premika pa (pre)počasi prihaja tudi v odločujočih političnih krogih. Očitno pa je, da sta $v$ številnih pomembnih tujih okoljih še vedno premalo prisotna znanje in zavedanje, in sicer po eni strani o pravih vzrokih jugoslovanske krize, po drugi pa o žal neuspešnih, številnih in dolgotrajnih slovenskih prizadevanjih za miroljubno in sodobno preurejanje jugoslovanske skupnosti.

Številni slovenski raziskovalci so s strokovnimi in osebnimi vezmi vpeti v mednarodno znanstveno skupnost, ki v sodobnih državah predstavlja pomemben segment javnega mnenja in tudi političnega pritiska. Zato pozivam vse raziskovalce $v$ Sloveniji, da izkoristijo vse dostopne komunikacijske možnosti (faksimile, elektronska pošta, telefon) in $z$ obveščanjem svojih kolegov v tujini omogočajo ustreznejšo obveščanje tujine o stanju $v$ Sloveniji, o okoliščinah pri razreševanju jugoslovanske 
krize in o naših stališčih o dogajanjih, da s tem tudi oni pripomorejo $k$ našemu hitrejšemu mednarodnemu priznanju.

Ob tej priložnosti naj se zahvalim vsem raziskovalcem, ki so v minulih dneh s samoiniciativnim obveščanjem svojih kolegov $v$ številnih tujih državah opravili izredno pomembno delo.

prof. dr. Peter Tancig, minister za znanost in tehnologijo 



\section{Kateri so glavni mejniki v slovenski znanosti po letu 1991?}

Znanost je integralni del širšega področja raziskav in razvoja. Vključena je $\mathrm{v}$ prizadevanja za družbeni napredek, kulturni razvoj in zaščito okolja. Raziskave in razvoj so področje, ki poteka tako na raziskovalnih ustanovah (univerze in inštituti) kot v gospodarstvu.

\section{Financiranje}

Slovenija je po letu 1991 krepko povečala sredstva, namenjena raziskavam in razvoju (pri tem upoštevamo tako raziskovalne ustanove kot gospodarstvo). To velja predvsem za vlaganja v gospodarstvo, ki so po letu 2009 prehitela evropsko povprečje. Prvi razlog za povečanje je spodbudna davčna zakonodaja, sprejeta leta 2007 , ki ponuja davčne olajšave za vlaganja v raziskave in razvoj, drugi razlog je precejšnja državna pomoč gospodarstvu v zadnjem desetletju. Kot lahko sklepamo po podatkih, imajo vlaganja v raziskave in razvoj neposreden vpliv na blagostanje družbe.

Toda povečevanje B DP, izboljševanje konkurenčnosti gospodarstva in skladen razvoj države - vse to je odvisno ne le od vlaganj v raziskave in razvoj, temveč tudi od drugih dejavnikov. V poglavju o financiranju so predstavljena nekatera dejstva, ki podpirajo trditev, da raziskave in razvoj ne spadajo med bistvene razloge, zaradi katerih Slovenija v zadnjih 25 letih ni napredovala toliko, kot bi si želeli.

Proračunsko financiranje slovenske znanosti $\mathrm{v}$ javnih raziskovalnih organizacijah (J RO), ki se je z vpeljavo programa Mladi raziskovalci v osemdesetih letih prejšnjega stoletja krepko povečalo, se v celotnem obdobju samostojne Slovenije žal krepko zmanjšuje. Kljub temu, da so se $\mathrm{v}$ zadnjih desetih letih $\mathrm{v}$ proračunih univerz in inštitutov precej povečala evropska sredstva in sredstva gospodarstva, je celotni obseg financiranja okoli 80 odstotkov evropskega povprečja. Knjiga ponuja možne razlage za take trende.

Kaj pa rezultati znanosti - so bila sredstva porabljena učinkovito? Kakšna je kakovost naše znanosti v okviru mednarodnih primerjav? 
Kako je naša znanost vpeta $\mathrm{v}$ slovensko družbo in koliko je zanjo pomembna?

\section{Oblike financiranja}

Zakon o raziskovalni dejavnosti, ki je bil sprejet leta 1991, je narekoval prehod na projektno financiranje in ministrstvo za znanost določil za osnovnega financerja. Financiranje slovenske znanosti se je $s$ tem približalo evropskemu modelu. Prehod na projektno financiranje je izdatno prevetril slovensko znanost, med drugim zato, ker je bilo treba za ocenjevanje projektov po novem pridobiti ocene tujih recenzentov. $\mathrm{V}$ letih od 1993 do 1995 so bili postopki razpisov zapisani v obliki pravilnikov.

Zgolj projektno financiranje ni zagotavljalo zadostne stabilnosti financiranja, kar je še posebej veljalo za raziskovalne inštitute. Pri izboru je prihajalo do konflikta interesov, saj so ga so opravili nacionalni koordinatorji, v pritožbenem postopku pa minister sam. Financiranje znanosti preko ministrstva torej ni zagotavljalo potrebne avtonomije znanosti. Leta 1998 je bila zato uvedena nova oblika financiranja, stabilno programsko financiranje, ki je projektnega nadgradilo in vpeljalo kombinacijo stabilnega in tekmovalnega načina financiranja, kar poznajo vse evropske države. Nov zakon o raziskovalni in razvojni dejavnosti (2002) je $z$ ustanovitvijo raziskovalne agencije povečal avtonomijo znanosti, z zakonsko ureditvijo programskega financiranja pa ji je omogočil večjo stabilnost. Leta 2005, leto po ustanovitvi raziskovalne agencije, se je pri izboru projektov uvedlo ocenjevalni postopek, pri katerem imajo odločilno vlogo tuji recenzenti in mednarodni paneli.

\section{Odličnost}

Slovenska znanost je v 25 letih dosegla velik napredek v znanstveni kakovosti, ki se še vedno krepi. Mednarodno primerljivi kazalniki znanstvene odličnosti jo danes uvrščajo $\mathrm{v}$ zgornjo tretjino $\mathrm{E} \mathrm{U}$. V tem kratkem času se je število objav v revijah, ki so indeksirane v bazi wo s, z zgolj polovice povzpelo kar na dvakratnik evropskega povprečja, odmevnost znanstvenih člankov oziroma njihova citiranost, ki je imela še slabše izhodišče, pa s tretjine na 150 odstotkov evropskega povprečja. Podobno velja za visokocitirane članke (zgornjih deset odstotkov).

Po citiranosti naših člankov smo bili leta 1992 dvakrat boljši od vzhodnoevropskih in pol slabši od sredozemskih držav. V zadnjem obdobju, po letu 2010, smo pred drugimi vzhodnoevropskimi državami prednost 
še povečali, sredozemske države pa prehiteli. V letu $1992 \mathrm{~s}$ polovice slovenskih raziskovalnih področij ni bil objavljen niti en članek v zgornji četrtini najkakovostnejših revij (A'), leta 2014 je bilo takih področij le še desetina. Enako statistiko so beležile tudi raziskovalne organizacije (po podatkih Sicrisa, http://www.sicris.si).

\section{Inovacijski sistem}

Sodelovanje gospodarstva $\mathrm{z}$ univerzami in inštituti je v Sloveniji primerljivo z evropskim povprečjem, drugi mednarodno primerljivi podatki pa so slabši kot pri znanstveni odličnosti. Število slovenskih mednarodnih patentov je od leta 1991 do danes naraslo s tretjine na polovico evropskega povprečja. Evropski inovacijski indeks je bil pred desetimi leti podoben kot pri citiranosti slovenskih publikacij, vendar danes še ni dosegel evropskega povprečja.

Slovenija je v 25 letih uvedla številne učinkovite ukrepe za večjo vključenost znanosti v druge družbene podsisteme. Med možnostmi, ki omogočajo financiranje, je treba omeniti aplikativne projekte, ciljne raziskovalne projekte, kompetenčne centre, spodbude ministrstva za gospodarstvo, javno agencijo za tehnološki razvoj Republike Slovenije (TIA), ki je bila ustanovljena v tem času. Med največjimi izzivi bodočega razvoja Slovenije pa je prav razvijanje mehanizmov dobro delujočega inovacijskega sistema.

\section{Ustanove}

Ker so pri odločitvah pomembni ljudje, ki o njih presojajo, je v preglednici 2.1 na naslednji strani seznam glavnih odločevalcev - ministrov za znanost, direktorjev Javne agencije za raziskovalno dejavnost (A RRS), rektorjev Univerze v Ljubljani (U L), rektorjev Univerze v Mariboru (U M) in direktorjev Instituta »Jožef Stefan" (I J S) - ter letaa njihovih mandatov. V knjigi se zaradi lažje berljivosti uporabljata izraza minister/ministrstvo za znanost, čeprav se je področje znanosti urejalo v okviru različnih ministrstev: Ministrstva za znanost in tehnologijo (do 2000), Ministrstva za šolstvo, znanost in šport (do 2004), Ministrstva za visoko šolstvo, znanost in tehnologijo (do 2012), Ministrstva za izobraževanje, znanost, kulturo in šport (do 2013), Ministrstva za izobraževanje, znanost in šport (2013-).

Pomembni akterji slovenske znanosti so bili tudi predsedniki znanstvenega sveta, najprej pri ministrstvu (Nacionalni znanstveno-raziskovalni svet), in sicer Boštjan Žekš (1992-1997), Jure Zupan (1997- 
2 Kateri so glavni mejniki v slovenski znanosti po letu 1991?

Preglednica 2.1 Seznam glavnih odločevalcev v slovenski znanosti po letu 1991

(njihova imena so zapisana v letu začetka njihovega mandata, kar ne velja edino za leto 1991; leto nastopa mandata novega odločevalca se prekriva z letom zaključka prejšnjega)

\begin{tabular}{|c|c|c|c|c|c|c|}
\hline Leto & Ministri & ARRS & $\mathrm{UL}$ & UM & IJS & SAZU \\
\hline 1991 & $\begin{array}{l}\text { Peter } \\
\text { Tancig }\end{array}$ & - & $\begin{array}{l}\text { Miha } \\
\text { Tišler }\end{array}$ & $\begin{array}{l}\text { Alojz } \\
\text { Križman }\end{array}$ & $\begin{array}{l}\text { Tomaž } \\
\text { Kalin }\end{array}$ & $\begin{array}{l}\text { Janez } \\
\text { Milčinski }\end{array}$ \\
\hline 1992 & & - & & & $\begin{array}{l}\text { Danilo } \\
\text { Zavrtanik }\end{array}$ & $\begin{array}{l}\text { France } \\
\text { Bernik }\end{array}$ \\
\hline 1993 & $\begin{array}{l}\text { Rado } \\
\text { Bohine }\end{array}$ & - & & $\begin{array}{l}\text { Ludvik } \\
\text { Toplak }\end{array}$ & & \\
\hline 1994 & & - & & & & \\
\hline 1995 & & - & Alojz Kralj & & & \\
\hline 1996 & $\begin{array}{l}\text { Andrej } \\
\text { Umek }\end{array}$ & - & & & Vito Turk & \\
\hline 1997 & $\begin{array}{l}\text { Lojze } \\
\text { Marinček }\end{array}$ & - & & & & \\
\hline 1998 & & - & $\begin{array}{l}\text { Jože } \\
\text { Mencinger }\end{array}$ & & & \\
\hline 1999 & & - & & & & \\
\hline 2000 & Lucija Čok & - & & & & \\
\hline 2001 & & - & & & & \\
\hline 2002 & $\begin{array}{l}\text { Slavko } \\
\text { Gaber }\end{array}$ & - & & & & $\begin{array}{l}\text { Boštjan } \\
\text { Žekš }\end{array}$ \\
\hline 2003 & & - & & $\begin{array}{l}\text { Ivan } \\
\text { Rozman }\end{array}$ & & \\
\hline 2004 & $\begin{array}{l}\text { Jure } \\
\text { Zupan }\end{array}$ & $\begin{array}{l}\text { Franci } \\
\text { Demšar }\end{array}$ & & & & \\
\hline 2005 & & & $\begin{array}{l}\text { Andreja } \\
\text { Kocijančič }\end{array}$ & & $\begin{array}{l}\text { Jadran } \\
\text { Lenarčič }\end{array}$ & \\
\hline 2006 & & & & & & \\
\hline 2007 & $\begin{array}{l}\text { Mojca } \\
\text { Kucler } \\
\text { Dolinar }\end{array}$ & & & & & \\
\hline
\end{tabular}

Nadaljevanje na naslednji strani

2002) in ponovno Boštjan Žekš (2002-2005), nato pa pri ARRS (znanstveni svet agencije) Peter Dovč (2005-2010), Vito Turk (2010-2015) in Marko Topič (2015-).

$\mathrm{Z}$ novo državo in zakonom o javnih zavodih so se postavili institucionalni temelji za slovenske znanstvene ustanove (javne raziskovalne 
Preglednica 2.1 Nadaljevanje s prejšnje strani

\begin{tabular}{|c|c|c|c|c|c|c|}
\hline Leto & Ministri & ARRS & UL & UM & IJS & SAZU \\
\hline \multirow[t]{2}{*}{2008} & Gregor & & & & & Jože \\
\hline & Golobič & & & & & Trontelj \\
\hline \multirow[t]{2}{*}{2009} & & & Stane & & & \\
\hline & & & Pejovnik & & & \\
\hline \multicolumn{7}{|l|}{2010} \\
\hline \multirow[t]{2}{*}{2011} & \multirow{2}{*}{\multicolumn{2}{|c|}{ Igor Lukšič }} & & Danijel & & \\
\hline & & & & Rebolj & & \\
\hline 2012 & Žiga Turk & & & & & \\
\hline \multirow[t]{2}{*}{2013} & Jernej & & Ivan & & & \\
\hline & Pikalo & & Svetlik & & & \\
\hline \multirow[t]{3}{*}{2014} & Stanka & József & & & & Marko \\
\hline & Setnikar & Györkös & & & & Mušič, \\
\hline & Cankar & & & & & Tadej Bajd \\
\hline \multirow[t]{5}{*}{2015} & Klavdija & & & Igor Tičar & & \\
\hline & Markež, & & & & & \\
\hline & Maja & & & & & \\
\hline & Makovec & & & & & \\
\hline & Brenčič & & & & & \\
\hline \multicolumn{7}{|l|}{2016} \\
\hline 2017 & & & Igor Papič & & & \\
\hline \multirow[t]{2}{*}{2018} & Jernej & & & Zdravko & & \\
\hline & Pikalo & & & Kačič & & \\
\hline
\end{tabular}

organizacije), ki so bile še naprej sestavljene iz dveh glavnih skupin, univerz (javni visokošolski zavodi) in inštitutov (javni raziskovalni zavodi). Leta 2003 je bila ustanovljena Univerza na Primorskem, ki so jo doslej vodili Lucija Čok (2003-2007), Rado Bohinc (2007-2011) in Dragan Marušič (2011-). Leta 2006 je bila s preoblikovanjem Politehnike Nova Gorica ustanovljena prva nedržavna univerza, Univerza v Novi Gorici, ki jo od takrat vodi Danilo Zavrtanik. Do leta 1999 so status javnega raziskovalnega zavoda dobili tudi manjši raziskovalni inštituti, ki so aplikativno usmerjeni: Geološki zavod Slovenije, Gozdarski inštitut Slovenije, Inštitut za ekonomska raziskovanja, Inštitut za kovinske materiale in tehnologije, Kmetijski inštitut Slovenije, Pedagoški inštitut, Urbanistični inštitut in Zavod za gradbeništvo Slovenije. Enak status sta dobila še Inštitut za novejšo zgodovino in Inštitut za narodnostna vprašanja.

Če primerjamo financiranje znanstvenih raziskav na slovenskih univerzah in inštitutih, ugotovimo, da je inštitutom namenjena več kot po- 
lovica sredstev, kar je med največjimi deleži v E U. Vendar pa se izkaže, da je prav izdatno financiranje inštitutov največja strukturna težava slovenske znanosti. Zakaj?

Za učinkovitost znanja je ključnega pomena sam prenos znanja - na študente, v gospodarstvo in na druga družbena področja. Glede prvega lahko hitro ugotovimo, da se znanje na študente seveda prenaša na univerzah, na inštitutih pa veliko manj. Povezava med znanjem in gospodarstvom pa se zatika zato, ker so večji inštituti praviloma usmerjeni v temeljno znanost, dosežki njihovih raziskovanj pa so za gospodarstvo manj uporabni. V letih 2008-2010 se je izvajal projekt pedagoškoraziskovalnega sodelovanja, ki je obetal pomembne izboljšave v pretoku znanja na druga področja. Projekt naj bi večino raziskovalcev povezal z univerzami, rezultati pa so bili zelo obetavni, saj se je v tem kratkem obdobju v visokošolski pedagoški proces vključilo prek 300 raziskovalcev. Žal pa je bil ukinjen (Slak, 2016).

\section{Mednarodno sodelovanje}

Po letu 1992 je Slovenija prevzela večino že prej obstoječih meddržavnih sporazumov o znanstvenem in tehnološkem sodelovanju in sklenila nove sporazume $z$ nekaterimi drugimi državami. Sporazumi financirajo krajše izmenjave naših in tujih raziskovalcev. Danes Slovenija na ta način sodeluje $z$ več kot 30 državami. Že v času približevanja E U, še toliko bolj pa po priključitvi k E U leta 2004 so se Sloveniji odprle nove možnosti, ki so finančno krepko presegle prejšnje oblike sodelovanja. Najpomembnejši projekt je Obzorje, naslednik Okvirnih programov E U, ki je Sloveniji prinesel skoraj 300 milijonov evrov sredstev. Veliko število projektov, ki jih je Slovenija pridobila iz Okvirnih programov E U, je preseglo evropsko povprečje in prispevalo $\mathrm{k}$ visoki rasti mednarodnega znanstvenega sodelovanja, ki jo je zabeležila Slovenija. Ker mednarodno sodelovanje opazno vpliva na boljšo kvaliteto raziskav, bi si morali bolj prizadevati tudi za pridobivanje najzahtevnejših evropskih projektov v okviru Evropskega raziskovalnega sveta (E RC).

Z vstopom AR R S v Evropsko znanstveno fundacijo se je začelo vključevanje agencije $v$ delo njenih sestrskih ustanov, kar je omogočilo nove raziskovalne projekte. Leta 2012 je ARRS postala ustanovni član Science Europe, nove organizacije združenja evropskih raziskovalnih agencij, ki slovenski znanosti odpira dostop do aktualnih znanstvenih tematik v svetu. V združenju Science Europe se je med drugim razvil za Slovenijo zelo koristen mehanizem »vodilne agencije«: države, ki se zavežejo k 
financiranju skupnih projektov, same financirajo svoje udeležence, ocenjevanje pa poteka samo $\mathrm{v}$ eni državi. Tak mehanizem omogoča kvalitetne mednarodne ekipe in pol cenejše ocenjevalne postopke, hkrati pa nacionalni denar ni porabljen za financiranje raziskovalcev $\mathrm{v}$ tujini, temveč doma.

\section{Transparentnost}

Bistveni elementi delovanja znanosti so transparentnost, javnost in preglednost rezultatov ter postopkov, ki pripeljejo do rezultatov. Zato ni naključje, da znanost vključuje transparentnost v vse svoje poslovanje. Slovenija je v leto 1991 vstopila $z$ zelo pozitivno dediščino finančne transparentnosti na področju znanosti. Leta 1994 jo je okrepila $z$ uvedbo podrobnih letnih poročil, to prakso pa zatem leta 1997 nadgradila z njihovo spletno objavo in leta 2006 še s sprotno spletno objavo vseh finančnih transakcij (ob mesečnih izplačilih). Transparentnost postopkov je bila leta 2008 podkrepljena $\mathrm{z}$ enotnim pravilnikom in metodologijo ocenjevanja, ki podrobno opredeljujeta vse bistvene ocenjevalne postopke.

Oba dokumenta se od takrat tudi redno izboljšuje. Leta 2010 je ARRS transparentnost znanstvenega delovanja opredelila v Pravilniku o postopkih (so)financiranja, ocenjevanja in spremljanju izvajanja raziskovalne dejavnosti, smiselno pa bi jo bilo zapisati tudi v Zakon o raziskovalni in razvojni dejavnosti.

Za transparentnost rezultatov je ključnega pomena sistem сов IS S, ki se je izkazal kot zanesljivo in uporabno bibliometrijsko orodje. Leta 1999 je spodbudil nastanek sistema SICRIS - slovenskega sistema sprotnega spremljanja raziskovalne dejavnosti -, ki beleži osnovne podatke vsakega raziskovalca, raziskovalne skupine ali raziskovalne organizacije. V njihovih predstavitvah so kontaktni podatki, kot so telefonske številke in spletne strani, pa tudi tekoči in že zaključeni projekti s povzetki in standardiziranimi izjemnimi dosežki ter povezave $z$ bazami, ki omogočajo vpogled v integralna besedila raziskav. Dostopne so tudi videopredstavitve, ki jih imajo raziskovalci na voljo.

Poenoten format bibliografij raziskovalcev, ki se je vzpostavil s sistemom сов ISS - trenutno je sistematično predstavljenih okoli 15.000 raziskovalcev -, je sicer dragoceno ocenjevalno orodje, ne pove pa dovolj o konkretnih rezultatih raziskovalnega dela, ki so zanimivi za splošno javnost in še posebej za potencialne uporabnike znanja, na primer za gospodarske družbe. Sistem S IC R Is, ki vsebuje tudi vsebinske informa- 
cije o projektih, je zato učinkovita nadgradnja bibliografskega sistema СОВISS in postaja iz leta v leto pomembnejši in bolj nepogrešljiv, kar potrjuje tudi obisk spletne strani, ki z leti strmo narašča. SICR IS nadgrajuje še nekaj slovenskih ponudnikov spletnih vsebin: Video lectures, Digitalna knjižnica in Atlas znanosti.

Uporaba bibliometrijskih metod, na katerih temeljita сов IS S in SICRIS, je opazno vplivala na rast slovenske znanstvene kakovosti. Ker je bila ta po osamosvojitvi razmeroma šibka, je slovenska znanost potrebovala zunanje ogledalo, zato se je ARRS odločila, da preuči vzorce znanstvenega objavljanja drugod po svetu in tako vpliva na primerljivost slovenske znanosti z evropsko. IZU M je omogočil, da so slovenski raziskovalci in ARRS S sistemoma COB IS S in SICRIS dobili neposreden vpogled $\mathrm{v}$ raziskovalne aktivnosti vsakega posameznika in raziskovalne enote, to pa je spodbudilo prizadevanje za mednarodno primerljivo kvaliteto in s tem spremembo kulture objavljanja. ARRS bibliometrijske podatke upošteva pri ocenjevalnih postopkih, univerze pri habilitacijah. Seveda se merila z leti spreminjajo - pred desetletjem je glavni kriterij pri dodeljevanju sredstev temeljil na bibliometriji, danes, ko smo se povzpeli v zgornjo tretjino držav EU, pa je bibliometrija ustreznejša za določanje vstopnih kriterijev za prijavitelje projektov in za kandidate za mentorje mladih raziskovalcev.

\section{Avtonomija}

Znanost za svoje delo potrebuje avtonomijo, tega so se zavedale že prve evropske univerze pred skoraj tisoč leti in jo vgradile v svoj institucionalni temelj. Tudi v Sloveniji imajo univerze največjo stopnjo avtonomije med javnimi ustanovami, saj univerzitetni uslužbenci sami izbirajo rektorja in pri tem ne potrebujejo soglasja vlade. Žal pa je avtonomijo mogoče izrabljati tudi za neetične in netransparentne prakse, kot se je nedavno pokazalo ob razkritju visokih avtorskih honorarjev velikega števila univerzitetnih profesorjev in neupravičenega izplačila dodatkov za stalno pripravljenost na univerzah. Poleg univerz imajo pri izbiri direktorja veliko avtonomijo tudi raziskovalni inštituti - vlada je pri odločanju prisotna le $z$ eno tretjino članov upravnega odbora. Vendar taka zakonska ureditev očitno ni samoumevna, saj je bila zakonodaja leta 2008 spremenjena, tako da je imela vlada večino, leta 2010 pa je bil zakon spremenjen nazaj na prejšnjo ureditev.

Precejšnja avtonomija, ki jo je pri financiranju znanosti vpeljala RSS, je bila po prenosu dejavnosti na ministrstvo za znanost v zadnjih le- 
tih prejšnje države precej okrnjena. Razmere so se spremenile šele po letu 2004, z ustanovitvijo ARRS, ki je prinesla ureditev, primerljivo z drugimi evropskimi državami - na izbor projektov politika nima vpliva. Vendar pa neodvisnost, v nasprotju z evropsko prakso, ne velja za izbor direktorja ARRS, saj ima vlada v njenem upravnem odboru večino. $V$ upravnih odborih raziskovalnih agencij $\mathrm{v}$ razvitem svetu državo običajno zastopa en sam predstavnik, pa še ta pogosto zgolj kot opazovalec, kar zagotavlja njihovo avtonomijo.

\section{Enakopravnost}

Enakopravna obravnava vseh ne pomeni zgolj omogočanja pravičnosti in enakopravnosti, ampak tudi boljše pogoje za razvoj, in nič drugače ni $\mathrm{v}$ znanosti. Uveljavljanje in dosledno uresničevanje načela enakopravne obravnave $\mathrm{v}$ znanosti spodbuja krepitev kakovostnih raziskovalnih kapacitet in s tem znanstvene odličnosti.

Po podatkih E U (European Commission, 2012) je med aktivnimi raziskovalci v E U $33 \%$ žensk, v Sloveniji pa $36 \%$. Med rednimi profesorji je bilo leta 2010 tako v E U kot v Sloveniji $20 \%$ žensk, $46 \%$ žensk pa Slovenija beleži pri podeljenih doktoratih, kar je prav tako enak odstotek kot v EU.

Normativni akti določajo, da mora biti med člani strokovnih teles in recenzenti vsaj tretjina predstavnikov enega od obeh spolov (to ne velja le za tehniške znanosti, kjer jih mora biti najmanj $20 \%$ ), kar AR RS uspešno izvaja tudi v praksi. Raziskovalkam se upošteva odsotnost zaradi porodniškega dopusta in se jim financiranje za ta čas podaljša. Vendar pa zastopanost obeh spolov na dveh področjih, povezanih s slovensko znanostjo, krepko šepa. Pri državnih nagradah za znanstvene dosežke je namreč med dobitniki najvišjih, Zoisovih nagrad, zelo nizek delež žensk, enako pa velja tudi za članstvo v SAZU.

\section{Etičnost}

Za znanstvenoraziskovalno dejavnost in za zaupanje družbe $\mathrm{v}$ znanost je zelo pomemben odgovoren odnos do raziskovanja. Motivacija za neetična ravnanja je običajno osebno okoriščanje, ki k razvoju znanosti nič kaj ne prispeva.

Raziskovalci in raziskovalne organizacije so sami odgovorni za to, koliko se načela poštenosti in mednarodno sprejeti etični standardi upoštevajo pri raziskovanju. Univerze, združenja raziskovalcev, akademije, agencije pri tem sprejemajo raznovrstne ukrepe za preprečevanje ne- 
etičnih ravnanj, običajno so to kodeksi, pogosto pa tudi postopki, ki obravnavajo kršitelje. Univerze in inštituti lahko ukrepajo tudi s prekinitvijo delovnega razmerja - taki primeri so žal znani tudi pri nas -, med ukrepi tujih raziskovalnih agencij je večletna prepoved prijavljanja raziskovalnih projektov spornih avtorjev, pri znanstvenih revijah pa uvrstitev spornih avtorjev na črno listo.

Menim, da bi bilo smiselno sprejeti kodeks poštenosti v raziskovanju in ustrezno zakonodajo, ki bi za kršitelje kodeksa predvidela sankcije. Da bi se pri tem izognili morebitnemu konfliktu interesov, bi morali pri presojanju sodelovati tudi tuji strokovnjaki.

\section{Slovenski jezik}

Znanstvena dela se objavljajo $\mathrm{z}$ namenom, da jih vsak lahko bere in upošteva pri svojem raziskovanju. Posledica tega načela je tudi dejstvo, da se danes praktično vsa znanstvena dela objavljajo v angleškem jeziku, naša zakonska ureditev pa je glede tega nedorečena. Znanstveno gradivo, potrebno za prenos znanja na študente ter $v$ gospodarstvo in druge segmente družbe, pa je po drugi strani napisano predvsem v nacionalnih jezikih.

Razvoj znanstvene terminologije ima velik pomen pri ohranjanju jezika in nacionalne identitete. Slovenija bi morala zato sistematično razvijati slovensko strokovno publicistiko, v kateri bi izhajali večinoma pregledni strokovni članki, in posebno skrb nameniti strokovnim terminološkim slovarjem, obenem pa spodbujati prevajanje slovenskih znanstvenih monografij pri uglednih mednarodnih znanstvenih založbah.

\section{Glavni dosežki na področju slovenske znanosti od začetka 20. stoletja do danes}

Do 2. svetovne vojne:

- Ustanovitev Univerze v Ljubljani.

- Ustanovitev Slovenske akademije znanosti in umetnosti (SAZU).

Do 1991:

- Ustanovitev Instituta »Jožef Stefan« (tudi Znanstvenoraziskovalnega centra Slovenske akademije znanosti in umetnosti - Z RC SAzU in Kemijskega inštituta).

- Finančni zagon v sredini osemdesetih: uvedba programa Mladi raziskovalci, nabava raziskovalne opreme. 
Po 1991:

- Izjemen dvig znanstvene kvalitete (po številu citatov s $30 \%$ na $150 \%$ povprečja v E U, po številu $10 \%$ najbolj citiranih del na milijon prebivalcev pa na $177 \%$ ).

\section{V znanosti smo $v$ Evropi}

Delo, 4. september 1991

Trditev iz naslova je treba pojasniti, saj ni namen tega teksta, da bi ugotavljal raven dosežkov naših znanstvenikov (gotovo je takšna, da nam pred sosedi $v$ Evropi ni treba zardevati), drugo je seveda izraba te znanosti. Pač pa odgovarja na vprašanje, ki si ga je v zadnjem času verjetno marsikdo zastavil: ali sta nam vojna in celotni mučni proces osamosvajanja začasno zmanjšala možnost vključevanja v evropske znanstvene projekte.

Res je tudi na področju znanosti ta čas marsikaj postavil na glavo, predvsem je hudo ogrozil predvideno republiško proračunsko porabo. Toda pri mednarodnem sodelovanju se je znanost $v$ glavnem vendar izognila strahu tujine pred tveganjem vlaganja v krizne države, na drugi strani pa so se obrestovale očitno zelo dobre mednarodne znanstvene naveze iz preteklosti. K spisku ugodnih okoliščin je treba prišteti še vtis, ki ga je v svetu vzbudila slovenska uspešna obramba (med spopadom z vojsko so naši znanstveniki svoje kolege v tujini seznanjali s temi dogodki in od njih nato dobivali čvrste izraze podpore), in nič manj uspešno promocijo Slovenije.

Tako se je lahko zgodil »čudež«, da je bila prav letošnje poletje, ko so prvič izbirali jugoslovanske projekte za evropski program TE MPUS, komisija iz Bruslja nenavadno naklonjena slovenskim predlogom. Dobili smo več, kot je kdorkoli pričakoval (od 7o predlogov so jih sprejeli 26), lahko pa bi še več, če nam ne bi nekoliko ponagajale vzhodne evropske sosede oziroma če ne bi nekatere institucije slabo razumele razpisnih pogojev. Tako so si nekateri tudi po lastni krivdi zapravili znatno triletno podporo Evropske skupnosti pri prenosu evropskih znanj v vzhodne države, ki znaša povprečno od 70 tisoč do 80 tisoč ekujev letno.

Povsem zataknilo se je le tam, kjer je vloga federalnih organov še vedno nepogrešljiva. To je predvsem program ALAMED, ki je namenjen znanstveni in tehnološki podpori mediteranskih držav. Med njimi je Jugoslavija kot edina vzhodna država in zanjo je bilo predvideno financi- 
2 Kateri so glavni mejniki v slovenski znanosti po letu 1991?

ranje pomembnih projektov - predlogi zanje so sicer zbrani, a Evropa odlaga izbor na boljši čas.

Res je velika sreča, da slovenska država tudi na znanstvenem področju uživa veliko več dejanskega zaupanja kot zvezna država. Z nekaj cinizma bi lahko rekli, da bi skupaj z znanostjo vsi že bili v Evropi, če bi tudi politiko znanstveno preverjali. 


\section{Vlaganja v raziskave in razvoj}

Raziskave in razvoj so široko področje, ki sega tako v raziskovalne ustanove, predvsem na univerze in inštitute, kjer večinoma poteka znanstveno raziskovanje, kot v gospodarstvo, kjer se skrbi za razvoj, financirajo pa ga država, E U in gospodarstvo.

V evropskih programih se zadnja leta RRD pogosto umešča $v$ širši sklop inovacijske dejavnosti, ki vključuje tudi komercializacijo. Za razvoj inovacijske dejavnosti so pomembne tako tiste inovacije, ki so plod razvoja v podjetjih, kot tiste, ki izhajajo iz znanosti v akademskem svetu (Science Europe, 2015).

Slika 3.2 na naslednji strani shematično prikazuje razmerja med glavnimi deležniki raziskav in razvoja v Sloveniji.

V preglednici 3.1 na strani 45 so podatki s slike 3.2 napisani v obliki zneskov v evrih, odstotkov B D P in primerjav z odstotkom B DP za E U28. Iz preglednice vidimo, da so podatki s področja razvoja za Slovenijo večinoma boljši, kot je povprečje $\mathrm{E} U$, podatki za znanost - vlaganja države v univerze in inštitute ter posledično tudi višina sredstev, ki jih te javne ustanove pridobijo iz vseh virov - pa so pod evropskim povprečjem. V knjigi so podrobno preučeni vsi elementi obeh slik, podane so časovne dinamike in povezave $\mathrm{z}$ rezultati.

\section{Doktorji znanosti gredo drugam}

Delo, 20. december 2012

Slovenija na prenekaterem področju postaja dežela protislovij, celo absurdov. Tako je tudi pri pridobivanju novih doktorjev znanosti. Imamo nadvse učinkovit - a nikakor ne poceni - podporni program, imenovan Mladi raziskovalci, brez katerega bi v zadnjih treh desetletjih dobili bistveno manj novih doktoric in doktorjev znanosti.

Po drugi strani imamo $v$ znanosti takšno politiko, da mladi doktorji doma vse težje najdejo zaposlitev in jo zato vse bolj iščejo čez mejo. To 
3 Vlaganja v raziskave in razvoj

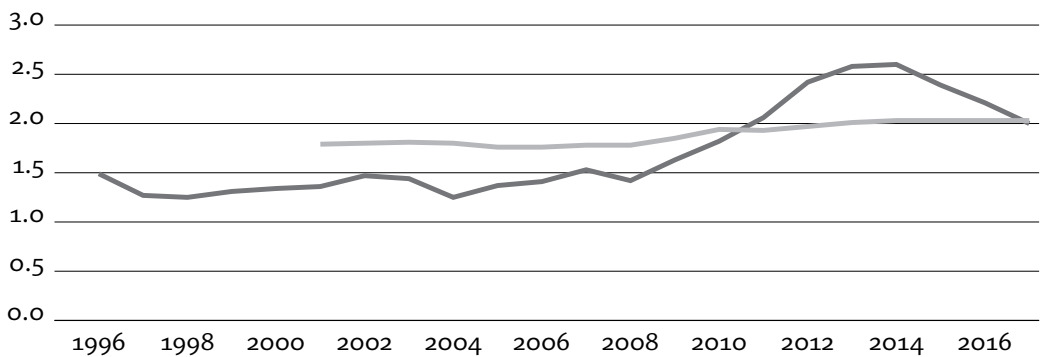

Slika 3.1 Višina vlaganj v raziskave in razvoj za Slovenijo in E U-28 v odstotkih B D P Temno - Slovenija, svetlo - E U-28. Po podatkih Eurostata (http://ec.europa.eu/ eurostat).

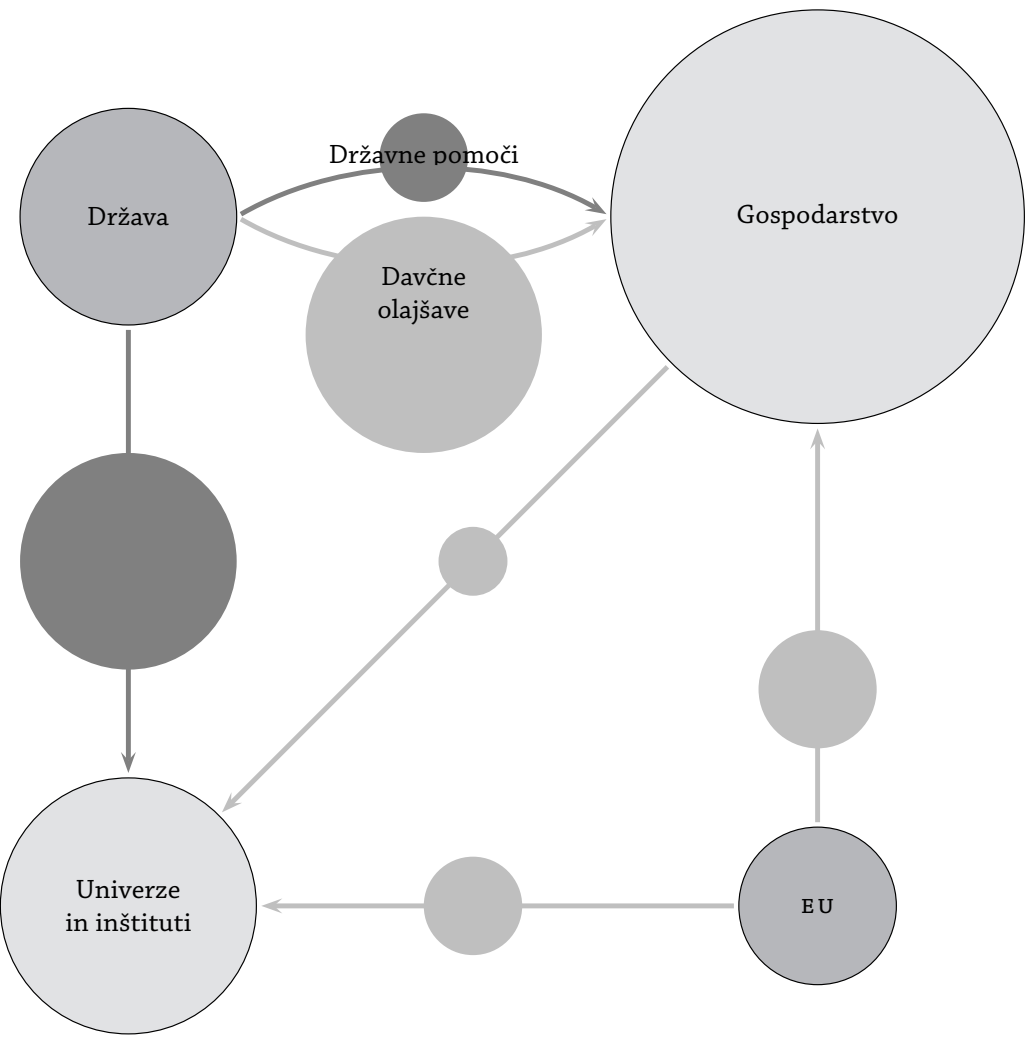

Slika 3.2 Shematična predstavitev vlaganj v RR pri glavnih deležnikih raziskav in razvoja (država, gospodarstvo, E U, univerze in inštituti)

Velikost krogov je sorazmerna $\mathrm{z}$ višino sredstev za leto 2015. Svetla barva pomeni, da je Slovenija nad evropskim povprečjem, temna, da je pod njim. Po podatkih Eurostata (http://ec.europa.eu/eurostat). 
Preglednica 3.1 Predstavitev denarnega toka pri glavnih deležnikih raziskav in razvoja

\begin{tabular}{lrrr}
\hline Deležniki raziskav in razvoja & $(1)$ & $(2)$ & $(3)$ \\
\hline Slovenija (+) & 853 & 2,20 & 108 \\
Država (vladni sektor) (-) & 169 & 0,40 & 66 \\
Država gospodarstvu (subvencije) (-) & 28 & 0,07 & 90 \\
Država gospodarstvu (ocena učinka davčnih olajšav) (+) & 180 & 0,50 & - \\
Država univerzam in inštitutom (-) & 141 & 0,40 & 67 \\
\hline E U (tujina) (+) & 90 & 0,23 & 115 \\
E U gospodarstvu (Okvirni programi in sredstva & 52 & 0,13 & 100 \\
strukturnih skladov) (+) & 38 & 0,10 & 160 \\
E U univerzam in inštitutom (večinoma Okvirni programi) $(+)$ & 590 & 1,53 & 135 \\
\hline Gospodarstvo (+) & 18 & 0,05 & 100 \\
$\quad$ Gospodarstvo univerzam in inštitutom (+) & 202 & 0,53 & 74 \\
\hline Univerze in inštituti (-)
\end{tabular}

OPOMBE (1) Višina sredstev (mio E UR), (2) delež BDP (v odstotkih), (3) delež E U28, (v odstotkih), (+) vrednosti nad evropskim povprečjem, (-) vrednosti pod evropskim povprečjem. Predstavljena sta velikost sredstev v milijonih evrov in v odstotkih slovenskega BDP ter primerjava teh deležev z EU (po podatkih Eurostata, http://ec.europa.eu/eurostat). Podatki so za leto 2015.

pa pomeni tudi, da se država lahkomiselno odpoveduje znanju in sposobnostim tistih, $v$ katerih izobraževanje in raziskovalno usposabljanje je vložila veliko davkoplačevalskega denarja.

Dovolj zgovoren je podatek, ki ga kaže tabela na tej strani, namreč, da se je število nezaposlenih doktorjev znanosti pri nas v zadnjih petih letih več kot potrojilo. A to so le tisti, ki so registrirani; domnevamo lah$k o$, da jih je še precej več, ki nezaposlenosti še niso prijavili oziroma so zaradi nje morali zapustiti domovino.

Res je, da pri nas še ne gre za množični beg možganov in tudi število nezaposlenih ni zastrašujoče. Toda primerjajmo podatek o 129 nezaposlenih doktorjih znanosti, kolikor jih je bilo konec letošnjega novembra, s podatkom, da je na primorski univerzi doslej skupno doktoriralo 74 študentov. Doktorji znanosti so ponos vsake univerze in vsake fakultete, zelo pomemben kazalec njihove kakovosti. Definitivno torej niso »izdelki«, za katere se šolam in tudi inštitutom, kjer so med študijem delali kot mladi raziskovalci, po doktoratu ni več treba brigati. Kljub temu večina teh ustanov ne zbira podatkov o usodi svojih doktorandov. Ena svetlih izjem je novogoriška univerza, kjer je doslej doktoriralo 98 študentov, od tega kar 21 iz tujine. Po doktoratu se jih je 69 zaposlilo 
v Sloveniji, 23 v tujini, za šest doktorjev znanosti pa nimajo podatkov. Posnemanja vreden zgled.

Je pa še nekaj, kar dokazuje, da študiju in znanju pri nas naglo pada vrednost. Nov pokojninski zakon, čeprav na videz ni neposredno pove$z a n s$ to tematiko, je vendar vsaj $v$ dvojem izrazito diskriminatoren do tistih, ki dolgo študirajo. Legalno najdlje študirajo doktorji znanosti.

$V$ doktorat znanosti je treba vložiti najmanj osem, realneje pa devet let študija. In kaj ima pri tem omenjeni zakon? Z njim je po novem onemogočeno upoštevanje let študija - nasprotno velja za služenje vojske -, poleg tega pa je novi zakon več kot potrojil ceno prostovoljnega pokojninskega zavarovanja in ga s tem za večino rednih študentov in nezaposlenih naredil nedostopnega. To pa tudi pomeni, da se bodo tisti, ki so vpisani $v$ redni doktorski študij, lahko pokojninsko zavarovali šele, ko bodo stari 27 let ali več.

Kdo ve, ali je kdo od avtorjev pokojninskega zakona in ljudi, ki so ga presojali, sploh pomislil na interese tistih, ki so menda naše upanje za rešitev iz stiske. Tako kot verjetno doslej še nihče ni resno razmišljal, kako usodne so napovedi, da bo vse več naših doktorandov za dolga leta ali celo za vedno odhajalo v tujino. Med drugim zato, ker si bodo tam lažje zagotovili tudi svoj socialni status. Jim to sploh lahko zamerimo?

\section{Proračuni za znanost}

Najpomembnejši financer znanosti je država (v nekaterih državah tudi regije). Slika 3.3 na naslednji strani kaže obseg slovenskega proračunskega financiranja znanosti (v\% B DP) od leta 1966. Sredstva za znanost, prikazana na sliki, do leta 1995 zajemajo Sklad Borisa Kidriča, RSS in ministrstvo za znanost. Več kot 95 odstotkov sredstev je namenjenih univerzam in inštitutom, zato so ti podatki primerljivi s tistimi po letu 1995, ki zajemajo višino sredstev državnega vlaganja (državni sektor) v univerze (visokošolski sektor) in inštitute (državni sektor). Podrobna struktura teh sredstev po podatkih iz letnih poročil po letu 1954 je prikazana na spletnih straneh ARR S v zavihku Financiranje in nadzor/Financiranje (https://www.arrs.gov.si/sl/finan/letpor), analiza teh podatkov pa v prispevku o zgodovini financiranja raziskovalne in razvojne dejavnosti (Novak in Demšar, 2012). Na sliki 3.3 na naslednji strani je predstavljeno tudi proračunsko financiranje znanosti v E U-28, in sicer v obdobju po letu 2000 in posebej v Franciji, ki ima med državami E U podatke dostopne za najdaljše obdobje. Glede na podobne 


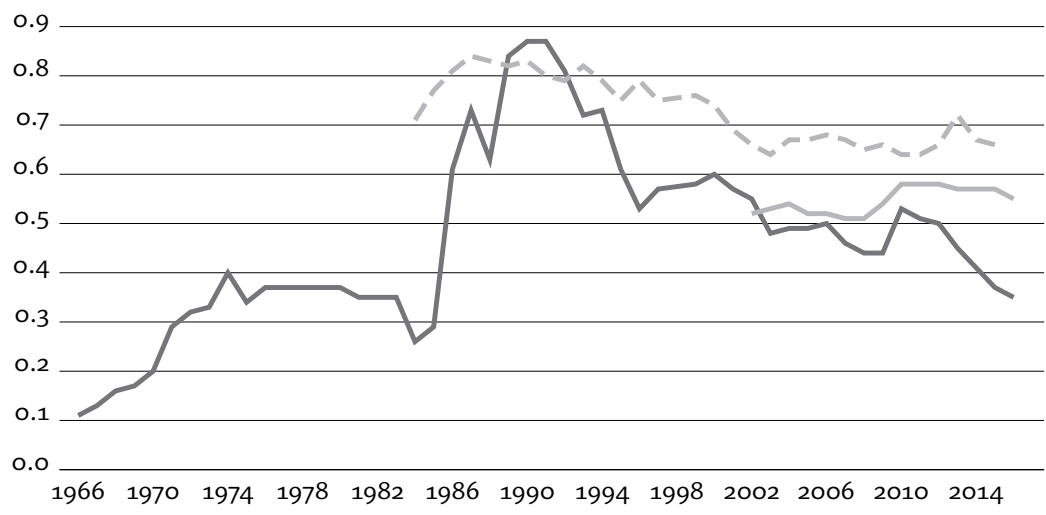

Slika 3.3 Proračunska sredstva, namenjena znanosti (univerzam in inštitutom) za daljše časovno obdobje, izražena v odstotkih B D P

Temno - Slovenija, svetlo - E U-28, črtkano - Francija. Podatki za Slovenijo so pridobljeni iz dveh virov, iz letnih poročil za financiranje znanosti do leta 1995 (Novak in Demšar, 2012) in iz podatkov o vlaganju države (državni sektor) v univerze (visokošolski sektor) in inštitute (državni sektor) za Slovenijo po 1995. Po enaki metodologiji so predstavljeni podatki za Francijo in E U-28. Po podatkih Eurostata (http://ec.europa.eu/eurostat).

vrednosti proračunskih vlaganj v Franciji in Evropi po letu 2000 lahko predvidevamo, da so vlaganja v E U tudi pred letom 2000 približno enaka francoskim.

Podatki za Slovenijo kažejo, da je bilo financiranje znanosti v šestdesetih in sedemdesetih letih prejšnjega stoletja srednje dobro, podobno kot $\mathrm{v}$ drugih vzhodnoevropskih državah. V sredini osemdesetih pa se je slovensko financiranje znanosti krepko povečalo: takrat je višina sredstev, ki jih je Slovenija namenila znanosti, precej presegla sredstva vzhodnoevropskih držav in za nekaj let celo Francije, ki je (bila) nad evropskim povprečjem. Zanimivo se je ozreti nazaj, v čase, ko je bila Jugoslavija $\mathrm{v}$ zatonu in pred razpadom, ko smo izgubljali in na koncu tudi izgubili upanje $v$ skupno državo in $v$ socializem. Na področju financiranja znanosti se je ravno $v$ tem času dogajalo nekaj povsem drugačnega. V Sloveniji je podpredsednik Republiškega izvršnega sveta postal direktor I J S Boris Frlec. Frlec in republiški sekretar Erik Vrenko sta največ pripomogla k doslej najizdatnejšemu povečanju financiranja znanosti v Sloveniji, ki je bilo namenjeno povsem novim področjem financiranja mladim raziskovalcem in raziskovalni opremi ter odpiranju novih propulzivnih raziskovalnih področij. Prava škoda za znanost, da se je Boris Frlec, velika osebnost prehoda v novo državo, v poosamosvojitvenem obdobju preusmeril v diplomacijo - postal je veleposlanik in zunanji mi- 
nister. Vletih pred osamosvojitvijo se je pojavil tudi nov zvezni fond, t. i. Matičev sklad, ki je med drugim omogočil vzpostavitev informacijskega servisa IZUM in z njim bibliografskega sistema COBISS. Takrat so se torej zgodile stvari, ki so imele velik vpliv na znanost in niso bile muhe enodnevnice, ampak so dolgoročno zvišale raven slovenske znanosti, kar se zdi glede na čas presenetljivo.

Druga značilnost, ki jo kaže graf, je zniževanje proračunskih sredstev, namenjenih za znanost, in to v celotnem obdobju samostojne Slovenije, če zanemarimo manjše izjeme. Financiranje znanosti v Sloveniji je bilo tako leta 1999 zadnjič v okviru evropskega povprečja, v letih po 2012 pa je padlo na porazni dve tretjini evropskega povprečja, torej na enako raven, kot je bila v sedemdesetih letih prejšnjega stoletja.

Ko opazujemo sliko 3.3 na prejšnji strani, se nehote vprašamo, kako je možno, da prihaja do takega zniževanja proračunskih sredstev za znanost, hkrati pa to ne velja za celotno področje vlaganj v raziskave in razvoj. Razlogov je več. Med prvimi je ta, da je znanost precej abstraktna, dolgoročna dejavnost, medtem ko je vloga tehnološkega razvoja veliko oprijemljivejša. Rezultati znanosti so za družbo koristni šele čez deset let ali celo čez več desetletij in na to se v proračunskih razpravah zlahka pozabi. Za zrele vladne odločitve je verjetno potrebna daljša državotvorna tradicija. Slovenskim raziskovalcem ne moremo očitati, da si za višja sredstva niso prizadevali. Pri tem je treba omeniti »belo knjigo«, dokument, ki sicer ni imel formalnega značaja državne resolucije, vendar je bila vlada $\mathrm{z}$ njim seznanjena in je prvemu ministru za znanost in tehnologijo, Petru Tancigu, predstavljal izhodišče za obravnavanje znanstvenega raziskovanja, obenem pa je šlo za podlago za malo poznejši prvi nacionalni program za to področje (Alkalaj in Baškovič, 1990). Ministru Tancigu je uspelo poenotiti razmišljanja širokega spektra tedanjih znanstvenih krogov (7o raziskovalcev in skupin) - dokument je utrdil pripadnost znanstveni skupnosti ter potrdil pomen znanosti v novih časih.

Pomembno vlogo pri strateških razmislekih je imel vladni Svet za znanost in tehnologijo R S, ki so ga zadnjih 25 let vodili Aleksander Bajt (1991-1994), Dušan Keber (1994-1998), Stane Pejovnik (1998-2002), Niko Toš (2002-2003), Anton Rop (2003-2005), Tomaž Pisanski (20052009), Marko Jaklič (2010-2014) in Tamara Lah Turnšek (2014-). Po vzoru razvitih držav je Svet pripravljal strateške dokumente, povezane s prioritetami in financiranjem znanstvenega raziskovanja. Leta 1995 je bil sprejet prvi tak dokument (Nacionalni raziskovalni program, 1995), ki je vključeval pomembno zavezo o vsakoletnem povečevanju sredstev 
za znanost: "Javna sredstva za raziskovalno dejavnost iz državnega proračuna naj bi v obdobju od 1995 do 2000 naraščala povprečno za $10 \%$ (realno) letno, če bodo to dovoljevale proračunske možnosti.«Vendar se je prav v tem delu pokazala omejitev, ki jo imajo v Sloveniji vsi strateški dokumenti - proračunsko namreč niso zavezujoči. Program v tej postavki zato ni bil uspešen, kar je razvidno iz slike 3.3 na strani 47: proračunska sredstva za raziskovalno dejavnost so se (tudi) v tem obdobju nižala, namesto da bi se višala. Za nekatere države, kot sta na primer Švedska ali Južna Koreja, so strateški dokumenti proračunsko zavezujoči in zato veliko operativnejši. Menim, da bi o tem morali razmisliti tudi v Sloveniji.

Znanost je področje, s katerim se ukvarja razmeroma malo ljudi; na raziskovalnih inštitutih denimo ni študentov, ki bi se seznanjali z raziskovanjem. Člani vlade zato niso dovolj motivirani, da bi mu namenili potrebno pozornost in ga obravnavali z razumevanjem. Povsem drugače je na primer z zdravstvom, od katerega smo vsi neposredno odvisni. Enako velja za policijo, pri vojski pa je že drugače: dokler smo imeli naborniško vojsko, z ustreznim financiranjem naše obrambe ni bilo večjih težav, ko pa smo prešli na profesionalno vojsko, pravega posluha za potrebe vojske ni bilo več in financiranje obrambnih izdatkov se je hitro skrčilo. Nekaj podobnega se je dogajalo tudi na področju znanosti. Raziskovalci, še posebej tisti, ki delujejo na inštitutih, običajno težje utemeljijo pomen svojega dela.

Kdo ve, kakšno bi bilo šele financiranje znanosti, če leta 2002 ne bi sprejeli zakona o raziskovalni in razvojni dejavnosti, ki je vsekakor zelo pomemben dosežek. Zanj je zaslužen minister Slavko Gaber, pri prizadevanjih za uveljavitev zakona pa mu je ob strani stal takratni predsednik Sveta za znanost in tehnologijo Niko Toš. Zakon med drugim opredeljuje tudi programsko financiranje (do takrat je bilo to urejeno v pravilniku), ki je znanstveni sferi omogočilo večjo proračunsko stabilnost. Gaber je med ministri, zadolženimi za šolstvo, glede proračunskega financiranja na tem področju pustil največji pečat, saj je vzpostavil sistem, ki slovenskemu šolstvu v primerjavi z evropskim zagotavlja nadpovprečno financiranje.

Javnosti o mehanizmih proračunskega financiranja in o pomembnosti umestitve znanosti v okvir določenega ministrstva ni veliko znanega. Ko sta znanost in visoko šolstvo prišla pod okrilje enega ministrstva, je postalo denimo zelo pomembno, iz katerih logov prihaja minister. Če je prišel z univerze - in teh je bilo največ -, je razmišljal približno tako- 
le: potem ko si izborimo denar za ministrstvo, bomo pri notranji delitvi sredstev pedagoškemu delu namenili več denarja, saj je v deležu za znanost univerzam namenjena le slaba polovica. Toda posledica delitve sredstev s takšnim izhodiščem je, da znanost izgublja pri obeh vrstah znanstvenih ustanov.

Znanost $\mathrm{v}$ zadnjem obdobju $\mathrm{v}$ ministrski resor spada skupaj z vso pedagoško verigo (vrtci, osnovne šole, srednje šole, univerze). Financiranje teh segmentov $\mathrm{v}$ okviru ministrstva poteka na različne načine. Sredstva za pedagoško delo univerze prejmejo v enem kosu - vsa sredstva dobijo od ministrstva za znanost in jih same notranje razporejajo -, znanost pa je financirana po proračunskih postavkah ARRS. V šolstvu (do stopnje univerze) ministrstvo neposredno financira plače zaposlenih. To pomeni, da vsako znižanje finančnih sredstev za šolstvo ogrozi številčnost zaposlenih, kar zelo vešče izkorišča sindikat, ki onemogoča vsakršno zniževanje sredstev. Posledica tega je, da je v obdobju sobivanja vseh teh segmentov pod isto ministrsko streho, ki je sovpadlo z zniževanjem proračunskih sredstev, največ izgubila znanost, nekoliko manj visokošolsko izobraževanje, ostali del šolstva pa jo je odnesel bistveno bolje. Najslabše so jo torej odnesli javni raziskovalni inštituti (znanost) in le malo bolje univerze (visokošolsko izobraževanje in znanost). Pomemben razlog za občutno nižanje sredstev za znanost je torej tudi sistemska ureditev oziroma umestitev znanosti in drugih segmentov v okvir skupnega ministrstva.

\section{Znanost čaka in zbira obljube}

Delo, 24. maj 2018

Trenutno klimo $v$ naši znanstveni srenji bi najlažje primerjali s čakalnico. Tisto, $v$ kateri je sicer znan željeni cilj, prav nič pa realne možnosti za njegov doseg. Znanstveni sferi, ki je bila v minulem letu presenetljivo glasna, po dveh zaporednih znanstvenih shodih, po več odprtih pismih in nedavni, bila je minuli četrtek, tribuni s predstavniki parlamentarnih strank dejansko ne preostaja nič drugega, kot da počaka na imenovanje nove vlade. Po izkušnjah nato še nekaj časa ne bo mogoče pričakovati konkretnih sklepov in ukrepov. To pa pomeni bolj ali manj mrtvi tek še nadaljnjih nekaj mesecev.

Seveda pa že obstajajo predvolilne obljube in napovedi, kako naj bi se v primeru zmage te ali one stranke godilo znanosti, ki sicer še vedno 
ostaja obrobna tema predvolilnih razprav. Sodeč po tem, kar je bilo slišati na tribuni in kar je zabeležila tudi anketa Dela, se večina strank strinja, da je potrebno za znanost nameniti odstotek BDP in to, kot napoveduje večina, napraviti do leta 2022. Torej ravno do izteka prihodnjega mandata, kar gotovo ni naključje. Kakorkoli že, omenjeni odgovori bi lahko bili spodbudni, če ne bi bilo izkušenj iz preteklosti.

Ob vseh vladnih menjavah po letu 2000 je znanost ostala $v$ senci domnevno veliko pomembnejših vladnih nalog, kar se je jasno odražalo tudi v proračunskih odmerah. Razen tega so se nekajkrat ponovile igrice $\mathrm{z}$ raziskovalnim zakonom. Vsakič je vlada končala svoj mandat s tako rekoč pripravljenim raziskovalnim zakonom, kjer je ključno delo opravila stroka in ki je vključeval tudi načrt boljšega financiranja. Nato je nova vlada pripravljeni zakon zavrgla in se lotila svojega. Ta ni dočakal uveljavitve. In zgodba se je ponovila...

A problem ni samo v zakonu in v dogovoru o financiranju. Odhajajoči premier je pred štirimi leti prezrl pismo KO S IS-a, neformalne koordinacije slovenskih raziskovalnih institucij, ki je vlado pozval k ponovni ustanovitvi ministrstva za visoko šolstvo, znanost in tehnologijo. Pri tem ni šlo za kakšno kaprico znanosti, temveč za realno ugotavljanje, da bi ministrstvo, ki ne bi vsebovalo celotne izobraževalne piramide, bolje služilo potrebam znanosti, hkrati pa se že dolgo kažejo negativne posledice prenosa tehnologije v okvir gospodarskega ministrstva. Toda o tovrstnem spreminjanju vladnih resorjev zaenkrat očitno ne razmišlja nobena stranka, čeprav je omenjeni poziv ves čas prisoten in aktualen.

Voditelj omenjene tribune, dr. Matjaž Kuntner, direktor Nacionalnega inštituta za biologijo, je že na začetku razprave dejal, da bodo znanstveniki izvoljene politike spomnili na dane obljube. Gotovo bo tako, toda politiki so po volitvah, vsaj v prvem delu mandata, precej gluhi za takšna opozorila. Zakaj? Zato, ker javnost na problematiko znanosti ne reagira niti približno tako, kot reagira na probleme zdravstva, sociale, okolja itd. Pač pa na to, kako se godi znanosti, še kako reagira gospodarstvo. A kdo bo to končno dopovedal široki bazi volivcev?

\section{Poslovni sektor}

$\mathrm{V}$ poslovnem sektorju imajo vlaganja $\mathrm{v}$ raziskave in razvoj najopaznejši učinek. Če so domišljeno vključena v organizacijske, finančne, proizvodne in prodajne procese podjetij, imamo od tega korist vsi - zaposleni, lastniki in država, ki pobere davke. 


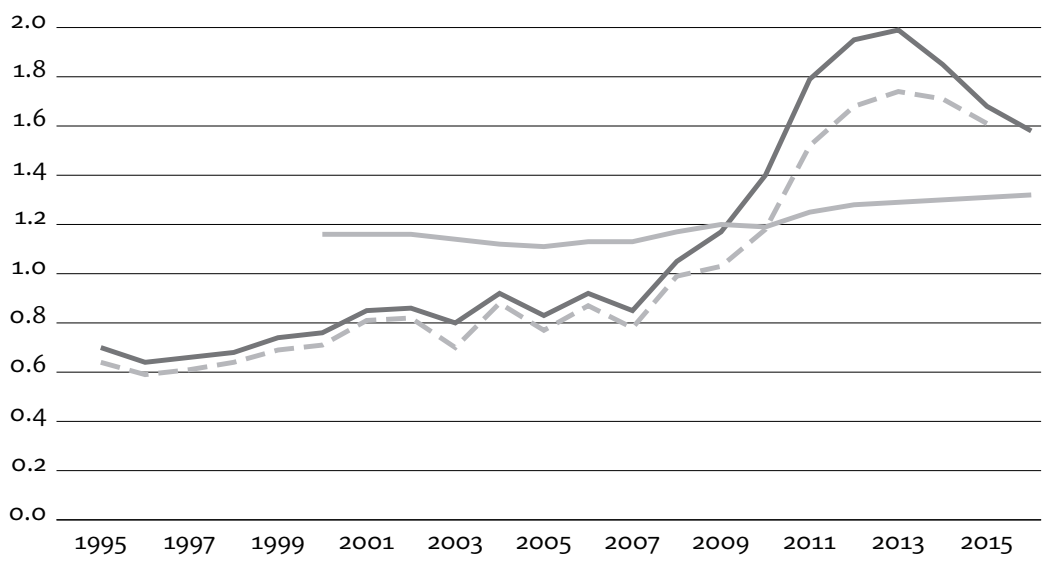

Slika 3.4 Višina vlaganj v raziskave in razvoj v poslovnem sektorju za Slovenijo in E U-28 v odstotkih B D P

Temno - Slovenija, svetlo - E U-28, črtkano - Slovenija brez državnih subvencij. Vir sredstev so lastna sredstva in sredstva države, po podatkih Eurostata (http://ec.europa .eu/eurostat).

Podatke o vlaganju v gospodarstvu Statistični urad R S pridobi z vprašalniki, ki jih izpolni poslovni sektor. Za vlaganje $\mathrm{v}$ raziskave in razvoj podjetja namenijo večinoma lastna sredstva, nekaj pa jih pridobijo od države. Ta torej lahko porabijo v podjetju v primeru, če imajo močne razvojne oddelke, lahko pa tudi za zunanje izvajalce, ki jih najamejo za posamezne faze razvoja, večinoma takrat, kadar potrebujejo storitve raziskovalcev $z$ univerz in inštitutov.

Slika 3.4 kaže višino vlaganj v raziskave in razvoj v slovenskem poslovnem sektorju in jih primerja $\mathrm{z} \mathrm{EU}$.

Kot lahko razberemo iz grafikona, so podatki o vlaganju v gospodarstvu spodbudni, kar sicer ne velja za podatke o vlaganju države v znanost na univerzah in inštitutih. Delež vlaganj gospodarstva $v$ raziskave in razvoj v Sloveniji je bil do leta 2009 pod evropskim povprečjem, potem pa ga je presegel. Eden od razlogov za vzpon je spodbudna davčna zakonodaja, sprejeta leta 2007, ki ponuja davčne olajšave za investicijsko dejavnost za raziskave in razvoj. Zakon o davku od dohodkov pravnih oseb (2006) je namreč vpeljal olajšavo za vlaganje $v$ raziskave in razvoj v višini $20 \%$ vloženih sredstev $\mathrm{v}$ raziskave in razvoj ter postopno zviševanje olajšave do $100 \%$ do leta 2012.

Drugi dejavnik vzpona so krepko povečana državna vlaganja $\mathrm{v}$ raziskave in razvoj v gospodarstvu po letu 2008 (svetlo rdeča krivulja na 
sliki 3.4 na prejšnji strani ponazarja stanje brez državnih subvencij). Financiranje poslovnega sektorja poteka $\mathrm{v}$ okviru različnih projektov in programov, ki so usmerjeni v celovito spodbujanje inovacijske dejavnosti. Med njimi so razvojno-inovacijski ali investicijski projekti, programi za spodbujanje zagonskih (start-up) podjetij, vključno z različnimi oblikami vavčerjev, programi, namenjeni podpori sodelovanju gospodarskih družb in javnih raziskovalnih organizacij, programi za podporno inovacijsko okolje za gospodarske družbe (tehnološki centri/tehnološki parki, inkubatorji, podporne mreže in grozdi itd.).

Premike v financiranju so sprožili nekateri strateški premisleki na vladnem nivoju. Leta 2005 je vlada na predlog sveta za znanost in tehnologijo sprejela strateški dokument, ki je začrtal povezovanje raziskovanja in razvoja, kar je razbrati tudi iz naslova dokumenta: Nacionalni raziskovalni in razvojni program (»Resolucija o nacionalnem raziskovalnem in razvojnem programu za obdobje 2006-2010«, 2006). V dokumentu so zapisali:

Za razvoj Slovenije v uspešno družbo znanja in njen preboj na področju gospodarske konkurenčnosti je tudi nujno povečevati vlaganja v R R v skladu $z$ barcelonskim ciljem doseganja $3 \%$ ravni naložb in ustreznim razmerjem med vlaganji zasebnega in javnega sektorja. Strategija s svojimi ukrepi predvideva postopno zviševanje vlaganj iz javnih sredstev $\mathrm{v}$ raziskave in razvoj do $1 \%$ B D P do leta 2010. Podvojitev vlaganj poslovnega sektorja bo med drugim dosežena $z$ ukrepi različnih politik za pospeševanje podjetniških vlaganj (domačih in tujih) v raziskave in razvoj. Hkrati bodo vzpostavljene spodbude javnim raziskovalnim organizacijam (J RO) za povečevanje deleža prihodkov od raziskav in razvoja, ki jih pridobijo na trgu.

In nekoliko naprej:

delež države pri financiranju R R v poslovnem sektorju se bo podvojil (s $5 \%$ na $10 \%$ ), prav tako tudi delež poslovnega sektorja pri financiranju R R v visokošolskem in državnem sektorju (z 10\% na $20 \%)$.

Slika 3.4 na prejšnji strani kaže, da so bile glavne točke programa z nekajletno zamudo realizirane.

Sodelovanje med gospodarstvom in znanostjo je v Sloveniji zelo intenzivno, nenehno se krepi in je povsem primerljivo z E U. Upajmo, da 


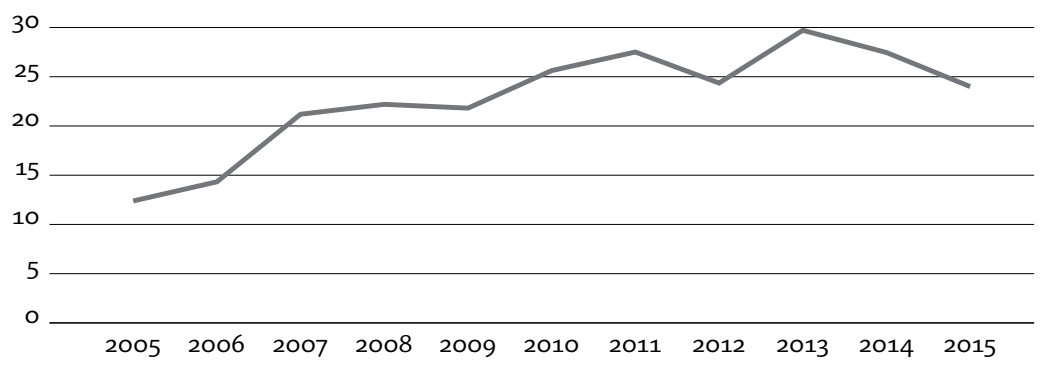

Slika 3.5 Sredstva, ki jih slovenske univerze in inštituti pridobijo iz gospodarstva v milijonih evrov

Po podatkih ARRS (https://www.arrs.gov.si/sl/analize/odlicnost).

padci v letih 2014 in 2015 ne naznanjajo trenda. Leta 2014 so gospodarski subjekti univerzam in raziskovalnim inštitutom izplačali 27 milijonov evrov za raziskovalno-razvojne projekte (slika 3.5), kar je nekoliko več od evropskega povprečja.

Približno toliko sredstev kot iz gospodarstva pridobijo univerze in inštituti še od ministrstev, ki niso pristojna za znanost (predvsem od ministrstev za kmetijstvo, finance, gospodarstvo in okolje). Glede na strukturo pridobljenih sredstev so naši raziskovalci torej v enaki meri kot $\mathrm{v}$ gospodarstvo vpeti tudi $\mathrm{v}$ druge družbene segmente (predvsem $\mathrm{v}$ družboslovje in biotehniko).

\section{Razvojni vrtičkarji}

Delo, 25. april 2013

Odkar se nam je razcvetela pomlad, lahko na vseh koncih države uživamo tudi ob pogledu na vrtičkarje, na te ljubosumne čuvaje malih solatnih in drugih gredic, globoko nesrečne, če morajo kaj deliti s sosedom. A kar pri vrtičkarjih ni posebno škodljivo - čeprav bi marsikje s skupnimi močmi lahko imeli več pridelka ali bi konjiček že zdavnaj spremenili $v$ donosno vrtnarstvo -, se nam $v$ znanosti, raziskavah in razvoju ne obnese in ne obnese.

Še zlasti škodljivo je razvojno vrtičkarstvo takrat, ko se ga lotijo vlade, ki povrhu vsega ne zdržijo niti cel mandat; to se nam je zgodilo že dvakrat zapored in se nam bo očitno še v tretje.

Prva Janševa vlada je ustanovila svet za konkurenčnost, ki ga je vodil takrat še nestrankarski razvojni minister Žiga Turk. A hkrati je Jure Zupan kot resorni minister dopustil, da vladni svet za znanost in teh- 
nologijo (SZT) ni naredil tako rekoč nič. Nato je prišla Pahorjeva vlada, svet za konkurenčnost je bil pozabljen, oživili pa so SZT, v katerem je prvi dve seji zdržal celo premier in napovedal preobrazbo Slovenije $v$ Silicijevo dolino.

Te nismo dočakali, smo pa dobili razvojno raziskovalno in inovacijsko strategijo (RISS) do leta 2020, a jo je druga Janševa vlada pustila $v$ predalu, tako kot skoraj do konca tudi SZT. Turk pa se kot superminister ni več utegnil ukvarjati s svetom za konkurenčnost.

$Z$ novo vlado je stari SZT znova dočakal Pahorja, tokrat kot predsednika republike, ne pa premierke Alenke Bratušek. Ta je kljub temu napovedala nov vladni svet za razvoj, ki ga bo vodilo gospodarstvo. Tudi RISS je prišel iz zamrzovalnika, vendar za zdaj njegovih učinkov kljub strateškim načrtom ni zaznati. Časa zmanjkuje, denarja še bolj.

Minister Jernej Pikalo ima sicer resor manj od predhodnika, a se mu je očitno težko uskladiti že samo med visokim šolstvom in znanostjo. Obojim obljublja dodatna sredstva, čeprav ima zaenkrat zagotovljenih le tistih $16 v$ proračun vrnjenih milijonov, ki so si jih že v prejšnji vladi podajali kakor pingpong žogico. Univerzam je minister zagotovil, da bodo dobile vse, kar jim je priborilo v parlamentu sprejeto dopolnilo proračuna, toda hkrati ministrstvo zagotavlja, da na področju znanosti išče rešitve, da bi »vsaj del novih doktorjev znanosti (teh bo letos rekordno število) zadržali doma«. Kje bo minister dobil dodatne milijone? To (tega) za zdaj (ne) ve samo on ...

Tudi premierka še ne razlaga, kako bo potekalo ustanavljanje napovedanega vladnega razvojnega sveta, ki bi ga rada zaupala vodstvu gospodarstva. Doslej še ni našla časa, da bi prisluhnila članom tistega razvojnega svetovalnega organa, ki ga vlada že ima, namreč Sz T. »Premierka verjetno sploh ne ve, da naš svet obstaja, «nam je po prvi seji v mandatu te vlade dejal njegov predsednik Marko Jaklič. A tudi on prav lahko ostane brez "svojega" sveta, saj RISS za letos predvideva združitev SZT s pokojnim svetom za konkurenčnost v nov vladni svetovalni organ - svet za raziskave in inovacije.

Bo vsaj ta prinesel kaj konkretnega ali bo končal le kot malo večji vladni vrtiček? 



\section{Oblike financiranja znanosti}

Sistem institucionalnega financiranja je model financiranja znanosti z najdaljšo tradicijo. Znanstvena dejavnost že najmanj dvesto let spada $\mathrm{k}$ poslanstvu univerz, ki so sredstva, s katerimi so razpolagala, namenjala svojim zaposlenim ne le za plače, ampak tudi za dolgoročno raziskovalno dejavnost in realizacijo posameznih idej. Podobno velja za raziskovalne inštitute, le da je to obdobje pri njih sto let krajše.

Po drugi svetovni vojni so se za začele ustanavljati raziskovalne agencije, ki so prevzele financerje raziskovalnih projektov. Nov model financiranja je izhajal iz predpostavke, da lahko razvoj znanosti pospešimo, če institucionalnemu financiranju dodamo financiranje dobrih idej, ki so izbrane na javnem natečaju. Stabilni del financiranja je bil tako dopolnjen s tekmovalnim.

V zgodovini financiranja slovenske znanosti so prevladovale institucionalne oblike, najizrazitejša tovrstna primera sta ljubljanska univerza in IJ S, za katera so bila že ob njuni ustanovitvi zagotovljena tudi proračunska sredstva za delovanje.

Odmik od institucionalnih oblik financiranja sta s financiranjem raziskovalnih tematik, ki jih izvajajo javne ustanove, prinesla programa URP in PORS, ki ju je razvila RSS, predhodnica ARRS. Raziskovalne tematike so bile podrobno razčlenjene na posamezne programske sklope, zanje pa predvideni posamezni vodje. Programski sklopi so imeli zagotovljeno stabilno financiranje, kar velja tudi za institucionalno financiranje, hkrati pa so bili podrobno (resda precej administrativno) razdeljeni na raziskovalne enote, po številu zaposlenih primerljive $z$ ekipami raziskovalnih projektov. Tak sistem je bil dobro izhodišče za pomembno reformo, ki jo je Slovenija izvedla takoj po osamosvojitvi in z njo prešla na tekmovalni način financiranja, na izbiranje projektov v odprtem natečajnem postopku. 


\section{Lobiji hočejo svoja "polja"}

Delo, 12. februar 1991

Ministrstvo za znanost in tehnologijo je v svojih Novicah pravkar objavilo "pravila obnašanja", ki naj bi odpravila večino pomislekov v zvezi z organizacijsko in vsebinsko novostjo $v$ tej sferi $-\mathrm{z}$ raziskovalnimi polji. Toda gotovo bo minilo še kar nekaj časa, da se bodo polja »prijela« v zavesti večine raziskovalcev in tudi v praksi dokazala svoj koristen vpliv.

Do tedaj bo veljal zaščitni refleks tistih, ki vidijo v tem še eno možnost za uveljavljanje moči tako imenovanih lobijev. Čeprav sistem polj ni namenjen neposrednemu odločanju o delitvi državnega denarja, ima na to precejšen vpliv z ocenjevanjem projektov, s predlogi kadrovskih rešitev, racionalizacije raziskovalnih področij, nacionalne raziskovalne strategije itd. Tega ne spremeni dejstvo, da je poskrbljeno za »zaščitne pregrade" pred morebitnimi lobističnimi prizadevanji.

Zadosten dokaz za to trditev je izredno prizadevanje vseh večjih raziskovalnih institucij, da zagotovijo "svojega človeka med nacionalnimi koordinatorji polj (ali vsaj njihovimi namestniki). Še bolje je, če imajo hkrati predstavnika še v svetu za znanost in tehnologijo - tako so spodaj podpisani vsaj zatrjevali izkušeni vodilni možje nekaterih inštitutov in fakultet. Seveda bi to željo lahko pojasnili tudi samo z zadovoljstvom, da ima institucija X ugledne raziskovalce, ki si zaslužijo omenjene funkcije. Vendar bi bila takšna vera le prenaivna.

Raziskovalni lobiji so bili, so in bodo. V njih je ostalo veliko ljudi, $k i$ "vedrijo in oblačijo «̌e vrsto let, sistemske spremembe pa so dale priložnost tudi novim ljudem. Nad tem dejstvom se lahko zgražamo ali se z njim sprijaznimo. Zdi se, da je vsaj resorno ministrstvo dovolj pragmatično, da se je odločilo za drugo možnost in ji dodalo - zdi se - iskreno prizadevanje, da lobističnemu vplivu otopi škodljivo ost. Pri tem je največje zaupanje izkazalo lastnim ljudem, saj ima ministrstvo pri večini pomembnih odločitev končno besedo. Pomemben člen so še eksperti posameznih strok, ki naj bi preprečili manipuliranje z znanostjo.

Vsekakor polja ne gre ocenjevati skozi prizmo morebitne nevarnosti. Kajti po drugi strani dajejo možnost večjega pregleda nad razmerami, tudi bolj s strani povezanega odločanja, torej so dejansko (lahko) orožje proti tistim, ki so jih že, ali pa jih še bodo, skušali uporabiti za svoje interese. Navsezadnje - polja naj bi tudi izginila ali se spremenila, če bi to ustrezalo interesom nacionalne raziskovalne strategije. 


\section{Projekti in tekmovalnost}

Izbor raziskovalnih projektov se je od leta 1991 naprej zgledoval po uspešnih tujih praksah. Za vodjo projekta je bil določen vstopni pogoj - minimalno število objav in vsaj en citat iz dotedanjih objav. Z uvajanjem tekmovalnega modela financiranja se je ministrstvo za znanost približalo sodobnemu evropskemu pristopu do znanosti. Novo projektno financiranje znanosti je vključevalo prijavo projekta, ocenjevanje, recenzije, izbor. Kot že rečeno, je bil prehod na nov sistem zaradi podrobnih razčlenitev na vsebinske sklope, ki sta jih prinesla predhodna programa URP in PORS, dokaj enostaven, saj so se vsebinski sklopi zlahka preoblikovali v projekte. Za projektno financiranje sta se odločno zavzela minister Peter Tancig in predsednik N Z RS Boštjan Žekš, ki sta postala ključna akterja te posodobitve. V letih od 1993 do 1995, ko je ministrstvo za znanost vodil pravnik Rado Bohinc, so bili postopki razpisov zapisani v obliki pravilnikov, ki so birokratskemu aparatu in raziskovalcem omogočili večjo predvidljivost formalnih postopkov.

Uvedba tekmovalnega sistema je v slovensko znanost prinesla svež veter, spodbudila je številne racionalizacije in izločanje neperspektivnih raziskovalnih tematik, kar je postopoma pripeljalo do mnogih uspehov slovenske znanosti. Projektno vlogo je bilo treba napisati v slovenskem in angleškem jeziku, da so jo lahko ocenili tudi tuji recenzenti, saj so njihove ocene postale eden od pomembnih kriterijev pri odločanju o izbiri projektov. Izbor je bil v pristojnosti nacionalnega koordinatorja raziskovalca, predstavnika enega od okoli 40 raziskovalnih področij, ki so v Sloveniji aktivna. $S$ tem se je avtonomija znanosti, kakršno je vzpostavila RSS, ohranila, a ne povsem. Zakon o raziskovalni dejavnosti, ki je bil sprejet leta 1991, je namreč opredeljeval prehod na projektno financiranje, hkrati pa je določil, da pristojnost za financiranje preide iz RSS na ministrstvo, kar je avtonomijo znanosti oslabilo - RSS je bila politično dokaj neodvisna ustanova, ministrstvo pa je seveda politična.

Sčasoma so se v sistemu financiranja projektov pokazale nekatere pomanjkljivosti, vendar so bile uspešno nadgrajene, in projektno financiranje ostaja temeljna oblika financiranja raziskovalne dejavnosti v Sloveniji. Prva pomanjkljivost se je pokazala predvsem v primeru raziskovalnih inštitutov, kjer je izključno tekmovalni način financiranja znanosti onemogočal kadrovsko in drugo razvojno načrtovanje. V letih 1998 in 1999 je bilo zato uvedeno kombinirano programsko in projektno financiranje. Drugi večji problem začetnega modela projektnega financi- 
ranja je bil konflikt interesov (Kristan, 2015). Do njega je prihajalo iz dveh razlogov: prvi je bil ta, da je pri odločanju ključno vlogo odigral nacionalni koordinator, zaradi česar je bila marsikatera odločitev sprejeta v korist njegove skupine ali ustanove, kjer je sicer deloval. Drugi razlog pa je bila vloga ministrov, ki so $v$ pritožbenem postopku odločali o desetih odstotkih sredstev za vsakokratni razpis, pri čemer kriteriji in postopek njihovega odločanja niso bili predpisani, zato je bilo pogosto pristransko.

ARRS je oba vzroka za pristranske odločitve hitro odpravila. V podrobno določenem postopku izbire je postalo obvezujoče mnenje recenzentov, nacionalne koordinatorje pa so nadomestile skupine uglednih tujih raziskovalcev (paneli). Direktor agencije v pritožbenem postopku ni imel več možnosti odločanja o desetih odstotkih sredstev, kakršno je imel pred tem minister, pač pa je bila pritožba omejena zgolj na popravek administrativnih napak v postopku, zaradi česar se je število uspešnih pritožb spustilo pod odstotek odobrenih vlog. Vse spremembe, ki so onemogočile konflikte interesov, so bile vpeljane leta 2005, pri čemer je bil pomemben sogovornik ARRS takratni minister Jure Zupan, ki je novo ureditev podprl in nekatere rešitve tudi sam predlagal.

Financiranje raziskovalnih projektov je od leta 1991 razdeljeno na financiranje osnovnih raziskav in financiranje aplikativnih projektov, ki jih sofinancira gospodarstvo. Razmerje med tema oblikama financiranja se je določalo glede na kvaliteto predlogov ter razvojne kapacitete gospodarstva in drugih sofinancerjev, pri čemer je narava raziskav v tehniki povsem drugačna kot $v$ humanistiki. Leta 2009, $v$ obdobju povečevanja finančnih sredstev, so se sredstva za projekte povečala s 50.000 evrov letno na dvakratnik te vsote, kar je zmanjšalo razdrobljenost prejšnje sheme za pridobivanje sredstev za raziskave.

Raziskovalni projekti so poleg tega postali tudi dober vzvod za povezovanje univerz in inštitutov ter medicinskih fakultet in univerzitetnih kliničnih centrov, saj je od leta $2010 \mathrm{v}$ projektni prijavi obvezna navedba različnih tipov javnih ustanov, ki si v primeru, da so na razpisu izbrane, razdelijo najmanj dvajsetodstotni delež sredstev. Pomembno vlogo $\mathrm{v}$ tekmovalnem načinu financiranja so $\mathrm{v}$ zadnjem obdobju odigrali še centri odličnosti kot oblika financiranja večjih raziskovalnih skupin in povezovanja $\mathrm{z}$ manjšimi, ki je bila marsikje učinkovito uporabljena za nakup nove raziskovalne opreme.

Da bi lahko čim zanesljiveje izbrali najboljše projekte, je AR RS v izbirni postopek vgradila raznovrstne mehanizme. Ključen v postopku je 


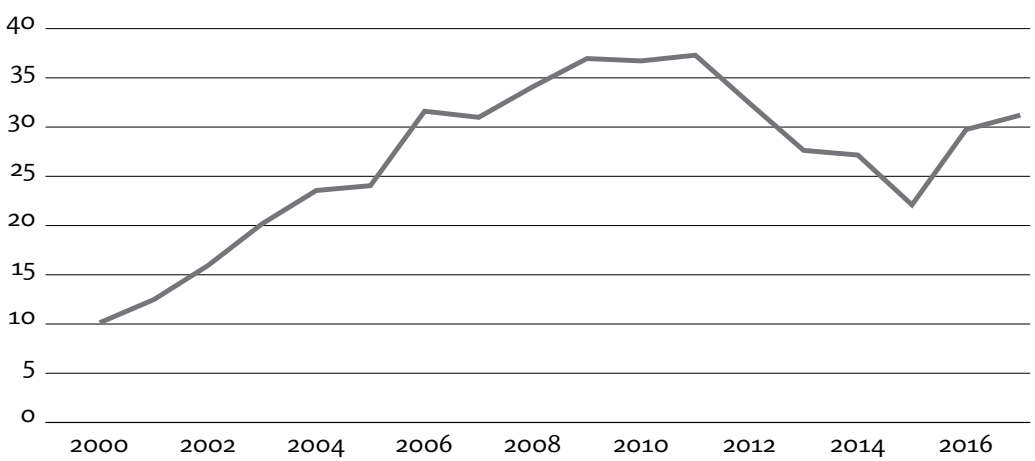

Slika 4.1 Državna sredstva, namenjena raziskovalnim projektom v milijonih evrov Po podatkih ARRS (https://www.arrs.gov.si/sl/analize/obsego1/). Slika kaže višino sredstev, ki jih je Slovenija namenila raziskovalnim projektom od uvedbe programskoprojektnega financiranja. Iz nje je razbrati zelo očitno finančno krizo v zadnjem obdobju, ki seveda kliče po odgovorih.

izbor recenzentov. Žal samo tehtanje njihove znanstvene odličnosti ne pripelje vedno do optimalnih odločitev, saj ne upošteva omejitev zaradi recenzentovega dobrega poznavanja tematike enega projekta in nekoliko slabšega poznavanje tematike drugega projekta, ki ga ocenjuje. Moderni informacijski proizvodi, kot je na primer sistem za izbiro recenzentov na Expert Outlooku (prej Reviewer Finder), razrešujejo problem recenzentovih neuravnoteženih strokovnih referenc za več projektov. Omenjeni informacijski sistem namreč omogoča vpogled v bibliografsko bazo recenzentov in izbiro tistih, ki z referencami dokazujejo poznavanje ustreznih področij za vse projekte, ki jih bo recenzent ocenjeval.

Pri izboru pa je seveda težko predvideti, ali bi recenzent lahko slabo opravil svoje delo oziroma bil pristranski, ker presoja na podlagi raziskovalnih šol oziroma usmeritev na nekaterih družboslovnih (ekonomija) in humanističnih (filozofija) področjih. Poleg tega je zaradi majhnega števila raziskovalcev na nekaterih področjih otežena primerjava med področji. Kako torej razrešiti dilemo, ali pri delitvi sredstev dati prednost dobro ocenjenemu predlogu s področja, ki že ima veliko dobro ocenjenih projektov, ali nekoliko slabše ocenjenemu projektu s področja, na katerem so projekti tudi v povprečju nižje ocenjeni? Pri obstoječem nizkem financiranju naše znanosti, ki ji institucionalno financiranje ne zagotavlja osnovnih raziskovalnih standardov, bo za tovrstne probleme težko najti rešitve. 


\section{Nepotrjena znanstvena odličnost}

Delo, 27. januar 2011

V prispevku na tej strani povzemamo rezultate zadnjih dveh razpisov za štipendije Evropskega raziskovalnega sveta, ki so si že pridobile prestižni pomen. Vsaka institucija, ki ima katerega od izbranih raziskovalcev, to poudarja $v$ svojih promocijah - na primer, Inštitut za znanost in tehnologijo (IS T) Avstrija ob predstavitvi direktorja prof. dr. Thomasa E. Henzingerja ni pozabil omeniti, da je bil izbran za štipendista ERC. Toda naše raziskovalne institucije možnosti za tovrstno promocijo žal še vedno nimajo.

Čeprav so v akademskem svetu primerjave s športom navadno sprejete z odporom, se vzporednice med vrhunskimi znanstveniki in vrhunskimi športniki kar same ponujajo. Predvsem zato, ker imajo pri nas oboji za seboj enako majhno zaledje, pri tem pa morajo konkurirati s predstavniki držav z neprimerno več prebivalci in tudi denarja za njihovo podporo. Kljub temu od naših vrhunskih športnikov zahtevamo in večkrat dobimo rezultate prav pri vrhu, kar vsekakor dokazuje, da za najodličnejše ni ovir in tudi ne izgovorov, da nimajo možnosti za enakovredno konkurenco.

Prav neenakovredni pogoji so bili zadnja leta največkrat navajani kot razlog za ta neuspeh. Naši znanstveniki, tisti uveljavljeni in oni na začetku kariere, naj bi bili, po teh tolmačenjih, povsem primerljivi s tistimi, ki jih je doslej izbral ERC, le da ne delajo v tako odlično opremljenih raziskovalnih laboratorijih in inštitutih. To naj bi dokazovala tudi dva slovenska raziskovalca v tujini, ki sta med štipendisti ERC. Podpisana si ne morem privoščiti, da bi dvomila o teh trditvah in argumentih, ker pač znanstveniki sami najbolje vedo, v kakšnih razmerah delajo sami in $v$ kakšnih njihovi kolegi na tujem. Vendar vseeno vem, da je vsaj nekaj naših laboratorijev po opremi tako rekoč enakovrednih najboljšim po svetu, zdaj pa smo dobili tudi centre odličnosti, ki imajo na voljo dovolj sredstev za potrebno raziskovalno infrastrukturo. Vendar je omenjeni razlog težko sprejemljiv še zaradi nečesa drugega.

Kar predstavljajmo si, kako bi se odzvala naša javnost, če v športu $v$ treh letih ne bi imeli nobenega zmagovalca ali vsaj koga na zmagovalnih stopničkah in da bi tako visoko prišla le Slovenca, ki sta člana tuje reprezentance. Kajne, da si tega ne morete niti zamisliti? V znanosti pa se je dejansko zgodilo, da $v$ treh letih nobeden od $v$ Sloveniji delujočih 
znanstvenikov ni prišel med več kot 1.700 tistih, ki jih je Evropski raziskovalni svet prepoznal kot najodličnejše z najobetavnejšimi pionirskimi raziskovalnimi projekti.

$V$ tem času so seveda naši znanstveniki doma in v tujini dosegali pomembne uspehe, kar nekaj jih je objavilo članke $v$ najprestižnejših znanstvenih revijah, mnogi so nosilci velikih mednarodnih projektov, nekaj jih je $v$ tujini dobilo ugledne nagrade. Toda vse to ne more zakriti dejstva, da se nobenemu od naših kandidatov - ni znano, koliko jih je bilo, ker tega podatka ERC ne objavlja po državah - ni uspelo uvrstiti $v$ razmeroma veliko skupino izbranih znanstvenih odličnežev. Torej teh bodisi nimamo bodisi se niso prijavili. Oboje je slabo. Razlogov za morebitno neprijavo tistih, ki bi lahko uspeli, seveda ne poznamo, toda nekateri naši znanstveniki, ki sem jih povprašala o tem, predvidevajo, da je koga od prijave na razpis odvrnil tudi strah pred neuspehom. Tako pa lahko še vedno domnevajo, da bi bili izbrani, če bi se le prijavili.

Seveda tudi naša država prispeva del denarja, ki ga ERC namenja za omenjene štipendije. Vendar $v$ tem primeru to nič ne pomeni, kajti Evropski raziskovalni svet je vnaprej zavaroval svojo neodvisnost $s$ poudarkom, da o izbiri odloča izključno odličnost in prav nič to, koliko denarja kdo primakne. Tako je edino prav, saj bi sicer zvodenel ves namen ERC. Morda pa je to za nas opozorilo, da smo se doslej $v$ EU tudi na področju znanosti preveč zanašali na svoj delež in da takrat, ko si ga moramo šele pridobiti, in to sami, ne pa morda v kakšni mednarodni raziskovalni navezi, odpovemo.

Naj si drznem ugibati, da je med globljimi vzroki te naše kronične neuspešnosti nemara to, da se pri nas premalo raziskovalcev sploh loteva pionirskih tem. Morda tudi zaradi utečene prakse, da mladi raziskovalci raziskujejo to, kar jim sugerirajo mentorji, uveljavljeni pa redko menjajo svoja področja raziskav. Morda so vsi nekoč, na primer v času študija, še načrtovali pionirske raziskave, a takrat ni bilo priložnosti zanje, po doktoratu ali še kasneje pa jim je že zmanjkalo zagnanosti.

Se morda, na srečo, motim in je dosedanja ničla $v$ ERC le plod zelo nesrečnega naključja?

\section{Programi in stabilnost financiranja}

Narava znanstvenega raziskovanja je takšna, da je pogosto težko predvideti njegove rezultate. To dobro ilustrira Kolumbovo odkritje Amerike, ki se je zgodilo povsem slučajno, saj se je Kolumb odpravil na pot v 
Indijo. Pomembna naloga financerjev znanosti je, da raziskovalcem, ki so se odpravili v Indijo, ne onemogočijo, da bi se ustavili v Ameriki, če nanjo na poti tja naletijo. V svetu zato večinoma izvajajo stabilno oziroma (kot ga pogosto imenujejo) institucionalno financiranje. V Sloveniji ima to vlogo predvsem programsko financiranje.

Pri celoviti oceni obeh načinov financiranja ne smemo zanemariti dejstva, da so raziskovalci javni uslužbenci, ki potrebujejo stabilne pogoje za delo, stabilno zaposlitev. Če primerjamo univerze in inštitute, lahko ugotovimo, da so za tekmovalne oblike financiranja univerze primernejše kot inštituti. Profesorji imajo stabilno pedagoško zaposlitev in del svoje dejavnosti lahko namenijo raziskovanju ali pa dodatna materialna sredstva za raziskave pridobijo $\mathrm{z}$ raziskovalnimi projekti. $\mathrm{Za}$ raziskovalce na inštitutih pa stabilni del zaposlitve predstavljajo raziskovalni programi, ki jim hkrati omogočajo, da se lahko posvetijo obsežnejšim, zahtevnejšim in dolgoročnejšim nalogam.

$\mathrm{Z}$ dilemami, ki so povezane $\mathrm{z}$ različnimi oblikami financiranja, smo se v slovenski znanosti prvič soočili ob nastanku samostojne države. Prejšnje financiranje je bilo pretežno stabilno, urejeno s programoma U R P (temeljno raziskovanje) in PORS (aplikativno raziskovanje). Toda stabilnost je dušila, praktično onemogočala razvoj novih področij in afirmacijo mladih raziskovalcev, ki niso pripadali že uveljavljenim skupinam. Celotno stabilno financiranje smo leta 1991 preobrazili v projektno financiranje, za dodelitev projektov smo začeli uvajati tuje recenzije, vodje projektov so morali izpolnjevati minimalne pogoje. Smele poteze so prevetrile našo znanost, hkrati pa so predvsem na inštitutski strani pripeljale do problemov glede (ne)stabilnosti zaposlitve. V letu 1998 smo sistem zato tako nadgradili, da smo za tisti del raziskovanja, ki se je lahko oblikoval v vsebinsko zaokrožene smeri, projektno financiranje spremenili v programskega. $S$ tem smo dosegli delno stabilnost zaposlitev, ki je pomembna za kontinuiteto raziskovalnih inštitutov, in obdržali tekmovalnost, ki je pomembna za kvaliteto znanosti. Pri programskem financiranju smo poleg tega uvedli nekoliko manj rigorozno ocenjevanje, kot velja za projektno.

Izključno projektno financiranje bi bilo, kot menim, sicer celo izvedljivo, vendar le, če bi raziskovanje potekalo zgolj na univerzah. Osnovni model bi na univerzah povsem zadoščal: profesorji prejemajo plačo za pedagoško delo, torej imajo zagotovljeno stabilnost, uspešnejši profesorji pa pridobivajo še dodatna sredstva za raziskovanje. Težko pa je na enak način stvari urediti na inštitutih, saj dodelitev sredstev za raz- 
iskovanje (kamor spadajo tudi plače) na vsake tri leta - seveda le, če je prijava na razpisu uspešna - in zaposlitev za nedoločen čas ne gresta skupaj. Tak sistem pripelje do tega, da se projekti sicer menjajo, vse ostalo pa bolj ali manj ostaja enako. V obdobju zgolj projektnega financiranja se je za takšno stanje našel celo poseben izraz, "raziskovalna dota«: ko raziskovalec zaključi projekt, dobi drugega, ki je približno enak prejšnjemu - ideja tekmovalnosti zato ne more zaživeti.

Po nekaj letih se je izkazalo, da je prav zaradi dvojnosti, različnosti inštitutov in univerz dejansko deloval le stabilni način financiranja, projektni pa zgolj pro forma. Takšna ureditev ni prinašala optimalne rešitve, kako razdeliti raziskovalna sredstva med raziskovalce na univerzah, ki se pretežno ukvarjajo s pedagoškim delom, in tiste na inštitutih, ki se ukvarjajo izključno z raziskovanjem. To je bil glavni razlog, da smo v letih 1998 in 1999 uvedli (sam sem vodil delovno skupino) kombinirano programsko-projektno financiranje.

Izhodiščna ideja sestavljenega modela je bila, da bi en del financiranja zagotavljal stabilnost, drugi del pa ohranjal tekmovalnost. V celoletni pripravi, ki jo je naročil minister Lojze Marinček, sta pomembno vlogo odigrala kasnejši minister Jure Zupan, ki je predlagal osnove modela, in ključni tehnični korektor Igor Levstek, ki je s sistematičnim popisom znanstvenih kadrovskih kapacitet in s stroškovno analizo porabe postavil osnovo za izboljšavo namenske porabe raziskovalnih sredstev. Vodja pravne službe Dubravka Krneta, tudi sicer zaslužna za celotno pravno ureditev slovenske znanosti, je pravilnik, ki je programsko financiranje opredeljeval, pripravila tako dobro, da se ga je nekaj let pozneje brez težav umestilo v zakon. Uvedba kombiniranega projektno-programskega financiranja leta 1998/99 je uresničila izhodiščno idejo in rešila mnoge probleme izključno projektnega financiranja.

Slika 4.2 na naslednji strani kaže primerjavo med stabilnim in tekmovalnim načinom financiranja znanosti v državah E U (Demšar in Bervar, 2010).

Analiza primerjave tekmovalnega financiranja (projekti, drugi razpisi) s stabilnimi oblikami, torej z institucionalnim financiranjem (programi, ustanoviteljske obveznosti), kaže, da je imela Slovenija leta 2008 izjemno visok delež tekmovalnega financiranja (polovica). Leta 2014 smo spremenili način financiranja mladih raziskovalcev iz tekmovalnega sistema, ko so za mesta kandidirali mentorji, v sistem stabilnega, po katerem so mladi raziskovalci po posebni shemi dodeljeni programskim skupinam za več let vnaprej. Mehanizem razporejanja mladih razisko- 


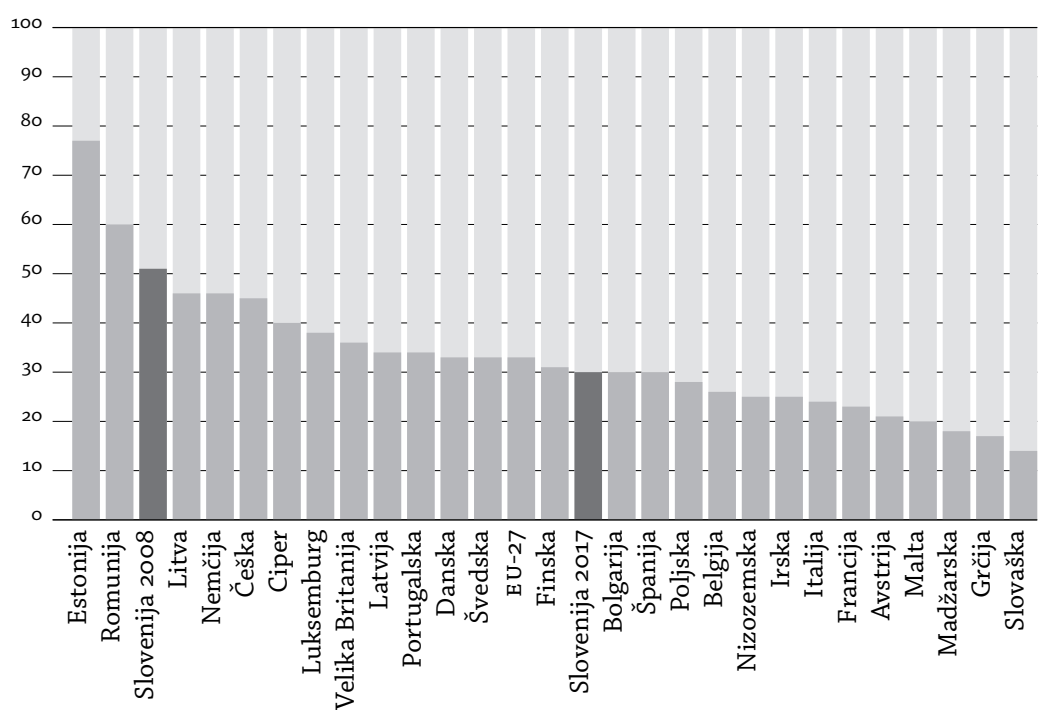

Slika 4.2 Razmerje med stabilnim in tekmovalnim načinom financiranja za leto 2008 ( $v$ odstotkih)

Slovenija ima dve časovni točki, poleg leta 2008 še 2017. Delež stabilnega financiranja je leta 2017 večji, ker je financiranje mladih raziskovalcev prešlo v model stabilnega financiranja. Povzeto po Demšar in Bervar (2010).

valcev je bil s tem vključen $v$ stabilno financiranje. Ob proračunskih rezih se je $\mathrm{v}$ preteklih letih delež projektnega financiranja poleg tega zelo skrčil, programski pa precej manj, zaradi česar je razmerje med stabilnim in tekmovalnim financiranjem danes blizu evropskega povprečja. Tekmovalni delež se je v letu 2014 znižal na 22 odstotkov, s povečanjem projektnega financiranja pa se je $\mathrm{v}$ zadnjih letih ponovno nekoliko dvignil, in sicer na 30 odstotkov, torej na raven evropskega povprečja. A tu gre le za razmerja, medtem ko je vsota celotnih sredstev, ki jih Slovenija namenja znanosti, tako majhna, da raziskovalcem povzroča številne težave in jih pogosto spravlja $\mathrm{v}$ zagato. Tako, denimo, razpis za razpisom prijavljajo svoje projekte, kar jim ne zagotavlja nujno potrebne osnovne raziskovalne kontinuitete in $\mathrm{s}$ tem povezovanja ter nadgrajevanja doseženih spoznanj.

Institucionalno financiranje je prineslo tudi pomembne proračunske vidike. Kot stabilni del financiranja slovenske znanosti je bilo $\mathrm{v}$ obsežnih krčenjih raziskovalnih sredstev v času finančne krize po letu 2009 najmanj prizadeto. Slika 4.3 na naslednji strani kaže, da se nobena oblika institucionalnega financiranja - torej financiranja raziskovalnih 


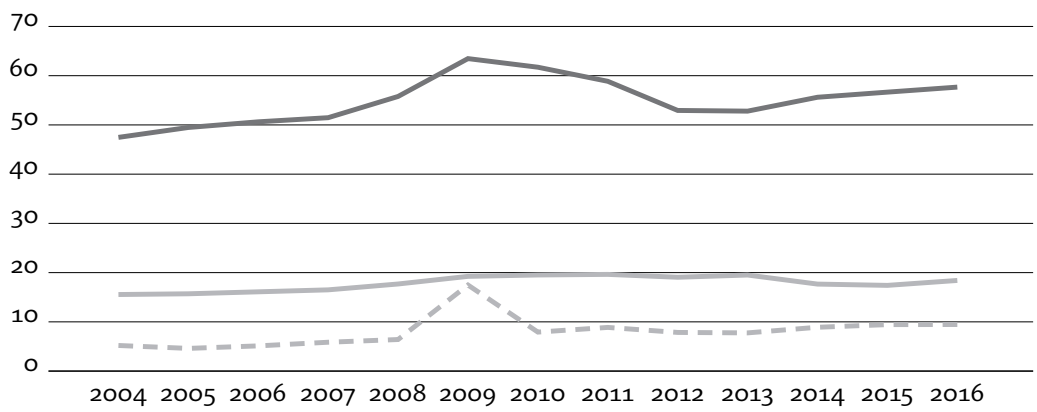

Slika 4.3 Obseg institucionalnega financiranja v milijonih E U R

Temno - raziskovalni programi, črtkano - infrastrukturni programi, svetlo - ustanoviteljske obveznosti. Po podatkih A R RS (https://www.arrs.gov.si/sl/analize/obsego1).

programov, infrastrukturnih programov in hladnega pogona inštitutov (ustanoviteljske obveznosti) - v času krize ni bistveno zmanjšala (prehod financiranja mladih raziskovalcev iz tekmovalnega sistema v stabilni na sliki 4.3 ni upoštevan). Bistvena raziskovalna področja torej niso bila vitalno prizadeta.

\section{Sklepni dan Hevreke: Trideset najodličnejših}

Razglasili najboljše programske raziskovalne skupine v preteklem letu Tudi o ponudbi ljubljanskega univerzitetnega inkubatorja

Delo, 27. oktober 2006

Ljubljana — »Morda si je še kakšna programska skupina zaslužila uvrstitev med najboljše, toda gotovo med izbranimi ni nobene slabe skupine, «je včeraj povedal predsednik znanstvenega sveta Javne agencije za raziskovalno dejavnost Republike Slovenije (A RRS) prof. dr. Peter Dovč po razglasitvi 30 najboljših raziskovalnih programov v letu 2005. To je bil tudi osrednji dogodek včerajšnjega sklepnega tretjega dne Hevreke.

Trideset najodličnejših programskih skupin za leto 2005 na področjih vseh znanstvenih ved je bilo izbranih izmed skupaj 262, kolikor jih je bilo predlani sprejetih v program javnega financiranja od leta 2004 do 2008. V naravoslovnih vedah so med najboljšimi programskimi skupinami Struktura hadronskih sistemov, Sinteze in transformacije organskih spojin, Izbrane teme teoretičnega računalništva in kombinatorične optimizacije ter Topologija in geometrija. V tehniških vedah so se najbolj izkazale skupine Separacijski procesi, Tankoplastne strukture in plazemsko inženirstvo površin, Umetna inteligenca in inteligentni 
sistemi ter Algoritmi in optimizacijski postopki v telekomunikacijah. $V$ medicinskih vedah so bile lani najboljše skupine Sistemske avtoimunske bolezni, Ginekologija in reprodukcija ter Geni, hormonske in osebnostne spremembe pri metabolnih motnjah. Edini zastopnik biotehniških ved je bila skupina Molekularna biotehnologija: od dinamike bioloških sistemov do aplikacij.

V družboslovju sta med najboljšimi Socialno delo kot nosilec procesov družbenega vključevanja in socialne pravičnosti v Sloveniji ter Družboslovna metodologija, statistika in informatika. Vhumanističnih vedah sta bili lani najodličnejši programski skupini Literarno-primerjalne in literarno-teoretske raziskave ter Idejnopolitični in kulturni pluralizem in monizem na Slovenskem v 20. stoletju.

Na prizorišču Hevreke v Cankarjevem domu so se včeraj zvrstili še drugi dogodki - med drugim konferenca o elektronskih medijih, Zveza organizacij za tehnično kulturo je razglasila najuspešnejše mlade talente, predstavili so ponudbo ljubljanskega univerzitetnega inkubatorja in slovenske rezultate $v$ 6. okvirnem programu.

Pravo sejemsko vzdušje, ki je tri dni vladalo v Cankarjevem domu, je vsekakor prepričljivo potrdilo dobro zamisel in organizacijo letošnje osrednje razvojno-znanstvene prireditve $v$ državi, ki je nazorno prikazala razvojno moč Slovenije in naj bi po napovedih $v$ prihodnjih letih dobila tudi mednarodne razsežnosti.

\section{Mladi raziskovalci}

Značilnost programa Mladi raziskovalci je, da so izbrani raziskovalci v raziskovalno delo vključeni že na začetku podiplomskega (doktorskega in prej tudi magistrskega) študija. Program jim pri tem zagotavlja odlične pogoje - redno zaposlitev ter materialna sredstva za raziskovanje in udeležbe na konferencah. Analize kažejo (Lucić, 2010), da so mladi raziskovalci po zaključenem usposabljanju in po pridobitvi naziva doktor znanosti uspešnejši od raziskovalcev, ki niso financirani iz državnega proračuna, in to tako po številu mentorstev ter projektnega in programskega vodenja kot po številu objavljenih raziskovalnih del in izjemnih dosežkov.

Program mladih raziskovalcev, ki so ga na začetku, leta 1985, imenovali Projekt 2.00o mladih raziskovalcev, je močno presegel zastavljeni cilj, torej 2.000 mladih raziskovalcev, saj je v okviru programa do konca leta 2015 doktoriralo 4.849 oseb, število vseh mladih raziskovalcev, ki 


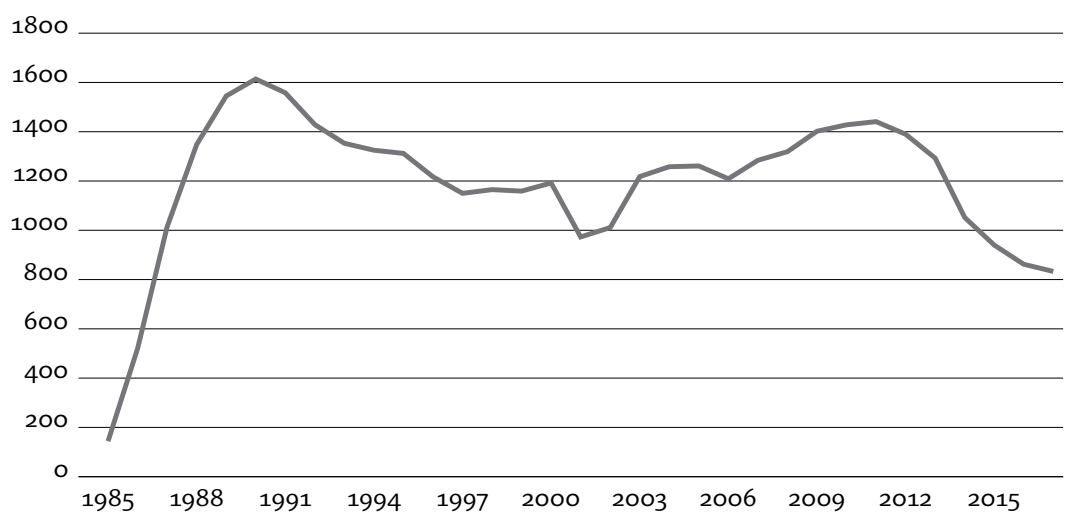

Slika 4.4 Število mladih raziskovalcev po letih od začetka (1985) do leta 2017 Po podatkih ARRS (https://www.arrs.gov.si/sl/analize/obsego1).

vključuje tudi magistrante, pa je še večje (slika 4.4) (Györkös in Novak, 2016). Zaradi projekta se je znatno povečal proračun za znanost, saj so mu bila dodeljena zajetna dodatna sredstva.

Način izvajanja programa se je z leti nekoliko spreminjal. V začetnem obdobju je bil študent izbran skupaj z mentorjem, bistveno vlogo pri izbiri pa je igrala povprečna ocena študenta. Slabost tega sistema je bila, da študenti pogosto niso mogli sami izbirati mentorjev, mentorji, ki so jim bili dodeljeni, pa niso imeli ustreznih znanstvenih kompetenc. ARRS je sistem zato izpopolnila tako, da je mentorje skrbno izbirala med najboljšimi raziskovalci. Mentorji so potem izbirali študente, ki so morali zadostiti minimalnim pogojem (povprečna ocena). A izkazalo se je, da ima tudi takšen sistem šibke točke, saj je onemogočal dolgoročno načrtovanje novih zaposlitev, poleg tega pa na nekaterih področjih ni bilo kandidatov za mlade raziskovalce. Leta 2014 je bil sistem zato ponovno nadgrajen. Programske skupine so odtlej obveščene o načrtovanem večletnem številu mladih raziskovalcev, ti pa si mentorja v okviru programske skupine izberejo sami. Pri tem morajo tako mentorji kot raziskovalci izpolnjevati zahtevane pogoje, ki zagotavljajo ustrezno znanstveno raven.

Slika 4.4 kaže, da se je po začetnem zagonu v letih pred osamosvojitvijo Slovenije financiranje mladih raziskovalcev $\mathrm{v}$ devetdesetih letih nekoliko zmanjšalo, vendar je program ostal bistveni sestavni del financiranja slovenske znanosti. Do leta 2006 so bili mladi raziskovalci razdeljeni v dve skupini, na mlade raziskovalce za obnovo raziskovalnih kapacitet univerz in inštitutov, ki jih je bilo v povprečju štiri petine, in 
na mlade raziskovalce za "pretok« v gospodarstvo (Računsko sodišče, 2010). Do uvedbe bolonjskega študija sta bili dve tretjini programa mladih raziskovalcev namenjeni doktorandom, tretjina pa magistrantom. Študentje, vključeni v program, so večinoma najprej pridobili magisterij, nato pa so doktorirali. Danes v programu sodelujejo samo doktorski študenti.

Oba cilja, ki si jih je program zastavil - obnova, pomladitev raziskovalnih kapacitet in povečanje števila doktorjev v gospodarstvu -, sta bila dosežena. $\mathrm{V}$ gospodarstvu, kjer $\mathrm{v}$ devetdesetih letih skoraj ni bilo doktorjev znanosti (le $3 \%$ ), jih danes dela $25 \%$, kar Slovenijo približuje razvitim državam, kjer jih je le kakih $10 \%$ več (Auriol, Misu in Freeman, 2013). Delež doktorjev, starih do 40 let, je bil leta 1988, v začetnem obdobju programa mladih raziskovalcev, 20-odstotni, že do leta 2005 pa se je povzpel na $40 \%$ in se na tem odstotku ustalil. Do padca števila mladih raziskovalcev v letu 2001, ki ga kaže slika 4.4 na prejšnji strani, je prišlo zato, ker se je začetek financiranja novih mladih raziskovalcev za to leto premaknil v januar 2002.

Zabeleženo zmanjšanje namenskih sredstev leta 2006 je posledica prehoda skupine mladih raziskovalcev za gospodarstvo na T I A, kjer pa je program hitro zamrl. Ta primer razkriva težave slovenskega inovacijskega sistema, ki v praksi ne deluje najbolje. Ministrstvo za znanost in ARRS sta del sredstev v okviru programa namenila prehodu mladih raziskovalcev $\mathrm{v}$ gospodarstvo, ko pa so mladi raziskovalci prešli $\mathrm{k}$ ministrstvu za gospodarstvo ali TIA, se njihovo število ni povečalo, kot bi pričakovali, ampak zmanjšalo, dokler ni bil program celo ukinjen. Za optimalno sodelovanje gospodarstva in znanosti pa je prav prehajanje mladih doktorjev $\mathrm{v}$ gospodarstvo zelo pomembno in bi ga morale $z$ ustreznimi programi spodbujati akademske ustanove, $z$ ustrezno plačno politiko pa država in gospodarstvo. $V$ zadnjih letih se je število novih mladih raziskovalcev prepolovilo, kar je seveda povzročilo tudi padec skupnega števila financiranih mladih raziskovalcev, kot lahko razberemo iz slike 4.4 na prejšnji strani - stanje se bo zato še nekaj let slabšalo, in vse več mladih bo po doktoratu iskalo boljše priložnosti v tujini.

\section{Zmagovitega konja se ne brca}

Delo, 27. oktober 2016

Ena najpronicljivejših potez slovenske politike vseh časov: to je samo ena od kopice laskavih oznak programa Mladi raziskovalci, ki smo jih 
slišali ob nedavni proslavitvi (že lani dosežene) tridesetletnice tega našega načina pridobivanja novih doktorjev znanosti. Pa to ni bilo jubilejno pretiravanje, temveč zasluženo priznanje vsem, ki so program zasnovali, in vsem, ki jim ga je uspelo zadržati. Seveda to kljub trudu ne bi bilo mogoče, če program ne bi bil tako potreben in tako dobro zasnovan.

Program, ki vključuje celotno »oskrbo« mladih raziskovalcev - solidno plačo, vse prispevke in materialne stroške - se je pri nas ohranil predvsem zato, ker je dajal prepričljive rezultate, torej nove raziskoval$c e, k i$ danes zasedajo večino ključnih mest $v$ naši znanosti in tudi marsikatero mesto $v$ upravi in politiki. Čeprav imajo vse članice EU svoje sheme spodbujanja mladih raziskovalcev, je naš program Mladi raziskovalci gotovo eden najizvirnejših in najcelovitejših. Pa tudi eden najdaljših, saj se je začel že veliko let pred snovanjem tako imenovanega evropskega skupnega raziskovalnega prostora in z njim povezane pridobitve izdatnih evropskih sredstev za mlade raziskovalce.

$V$ tem dolgem obdobju seveda ni šlo brez sprememb. Takih, ki so programu koristile, in tudi takih, teh je bilo morda še več, ki so mu škodile. Precej sprememb je bilo nujnih, saj so se razmere $v$ teh desetletjih močno spremenile. Sprva je pri nas hudo primanjkovalo tako doktorjev znanosti kot drugih strokovnjakov. Tako je program poleg doktoratov in magisterijev podpiral tudi specializacije in celo neformalno usposabljanje. Razumljivo je, da je sčasoma od teh ostal le še doktorski študij. A zanj je $v$ današnjem programu po mnenju mnogih na voljo premalo časa, namreč tri leta in pol (prej štiri in pol), to pa zavira odločanje za bolj tvegane raziskovalne projekte.

Sprememba na slabše je gotovo tudi to, da se je program, ki je od vsega začetka med ključne cilje uvrščal usposabljanje raziskovalcev za delo $v$ gospodarskih podjetjih, tega bolj ali manj držal samo v prvih dveh desetletjih, od tega zadnja leta s samostojno financiranim programom. Kmalu po selitvi gospodarskega dela programa mladih raziskovalcev na tehnološko agencijo (TIA) pa je ta finančni vir presahnil in ga še vedno ni, čeprav bi ga že davno lahko nadomestili. Tudi zato je skupno število mest za mlade raziskovalce $v$ zadnjih letih precej manjše kot prej.

Skoraj ves čas program bremeni to, da sloni predvsem na odličnosti mentorjev in zadnji dve leti raziskovalnih skupin, odličnost mladega raziskovalca pa ima vlogo samo, če je zanj na voljo prosto mesto mladega raziskovalca. Krivico, ki je doslej nekaterim zelo sposobnim diplomantom onemogočila doktorat ali pa jih prisilila $v$ spremembo raziskovalnih načrtov, bodo po napovedih $v$ prihodnje popravili z dodatnim de- 
ležem mest za mlade raziskovalce, podeljenih izključno na podlagi odličnosti kandidatov.

Še najmanj vneme pa je za odpravljanje morda največje ovire za učinkovitost programa mladih raziskovalcev. Namreč tako rekoč nikakršne skrbi za njihov prehod iz programa. Državi, ki navsezadnje za usposabljanje mladega raziskovalca povprečno porabi 30.000 evrov na leto, ne bi smelo biti vseeno, če se bo ta po doktoratu (prisilno) zaposlil kot uradnik ali $v$ tujini.

\section{Raziskovalna oprema in druga področja financiranja}

$\mathrm{Ob}$ institucionalnem financiranju in financiranju raziskovalnih projektov se pri znanstveno-raziskovanli dejavnosti pogosto pojavijo še potrebe po financiranju nekaterih drugih elementov, pomembnih pri raziskovalnem delu, kot so usposabljanje novih doktorjev, raziskovalna oprema, strokovna literatura in podatkovne baze. Zakaj ne bi tega prepustili akademskim ustanovam in jim za to preprosto namenili dodatnih sredstev? Zato, ker imajo slovenske akademske ustanove precej različne standarde. Smiselno je torej, da vsem omogočimo izvajanje teh elementov oziroma dostop do njih, saj so prav tako pomembni za doseganje dobrih rezultatov. Takšno izhodišče prinaša dobre rezultate, kot smo lahko videli na primeru programa Mladi raziskovalci, ki smo ga analizirali v prejšnjem poglavju.

Financiranje mladih raziskovalcev se je razvijalo na podoben način kot financiranje večje raziskovalne opreme. V sredini osemdesetih let prejšnjega stoletja so se $\mathrm{v}$ proračunu hkrati z novimi sredstvi za program mladih raziskovalcev zagotovila tudi sredstva za večjo raziskovalno opremo. Sodobna in kvalitetna raziskovalna oprema je za večino raziskovalnih področij bistvenega pomena, saj jim taka oprema, zaradi katere imajo ne nazadnje enako izhodišče kot njihovi kolegi v tujini, pomaga, da lažje in hitreje pridejo do pomembnih rezultatov. Vpogled $\mathrm{v}$ podatke o vrsti slovenske raziskovalne opreme, načinu dostopanja do nje in njeni izkoriščenosti omogoča sistem SIC R IS. Slika 4.5 na naslednji strani kaže višino sredstev, namenjenih za raziskovalno opremo, ki je res precej nižja od sredstev za raziskovalne projekte, pa vendar so ta sredstva bistvenega pomena, saj brez opreme projektov ne bi mogli izpeljati. Graf prikazuje občutno znižanje sredstev za raziskovalno opremo v zadnjem obdobju, iz česar tudi sledi, da je obstoječa oprema iztrošena. 


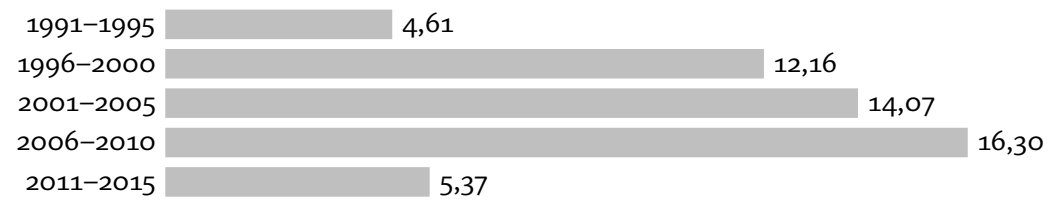

Slika 4.5 Sredstva za raziskovalno opremo v milijonih evrov po petletnih obdobjih Po podatkih ARRS (https://www.arrs.gov.si/sl/finan/letpor/).

Sam način financiranja raziskovalne opreme je zelo pomemben. Že na začetku je bil zasnovan tako, da je bilo proračunsko financiranje pogojeno s sofinanciranjem javnih raziskovalnih ustanov in delno industrije. Prav ta soudeležba je bistveno izboljšala namensko porabo sredstev, saj so bile raziskovalne organizacije prisiljene $\mathrm{v}$ racionalizacijo nabavnih stroškov. Druga področja (recimo medicina in vojska) so ravno zaradi izključno proračunskega financiranja svoje opreme dovzetnejša za koruptivne zlorabe. Za nakup velike raziskovalne opreme je poleg tega predvidena precej visoka minimalna vrednost, zaradi česar mora ustanova potrebe različnih oddelkov uskladiti in jih tudi dolgoročno načrtovati. Bolje organizirane ustanove (recimo IJS) so zato pridobile več raziskovalne opreme kot, denimo, ustanove, ki so notranje manj povezane. Verjetno bi to dejstvo veljalo še bolj upoštevati in glede na velikost ustanov ter njihovo uspešnost pri pridobivanju projektov sredstva za raziskovalno opremo dodeljevati $\mathrm{v}$ enem kosu. $\mathrm{V}$ tem primeru bi se univerze začele opremljati $z$ večjo in tudi dražjo opremo.

Med pomembne elemente uspešnega raziskovalnega dela spada tudi dostop do strokovne literature in podatkovnih baz. Gre za področje, ki bi ga večina raziskovalcev kar prezrla, pa vendar je ta infrastruktura ključnega pomena za slovensko znanost. Razlog, da je to področje med znanstveniki prezrto, bi lahko iskali v tem, da se zdi uporaba strokovne literature in baz podatkov nekaj samoumevnega, saj je pri nas dobro organizirana in zlahka dostopna. A da tako deluje, so seveda prav tako potrebna ustrezna sredstva, česar se raziskovalci pogosto verjetno niti ne zavedajo. Še pred dobrimi desetletjem je to področje zajemalo predvsem nabavo znanstvenih revij, ki so bile tiskane na papirju in so jih raziskovalci lahko dobili v knjižnicah. $Z$ razvojem informacijskih orodij se je položaj temeljito spremenil, saj so danes praktično vse znanstvene revije dostopne na spletu; $v$ okviru plačljivih paketov je na voljo več deset tisoč revij. A R R S je leta 2008 podvojila sredstva za nabavo teh paketov in s konzorcijskimi pogodbami med vsemi slovenskimi univerzami 
ter večjimi inštituti dosegla odlično pokritost - našim raziskovalcem so dostopne domala vse kvalitetne znanstvene revije.

Ministrstvo za znanost je pri vsem tem odigralo pomembno vlogo. Finančno je podprlo prvega ponudnika interneta v Sloveniji, slovensko akademsko raziskovalno omrežje ARNES, in leta 1998 sredstva zanj še povečalo, kar se je izkazalo za dobro strateško odločitev. Poleg tega je ministrstvo, tako kot tudi ARRS, že na začetku podprlo I ZU M, ki s sistemoma COBISS in SICRIS skrbi za informacijsko podporo slovenske znanosti, kar je podrobneje predstavljeno $\mathrm{v}$ poglavju o transparentnosti.

\section{Gospodarsko raziskovalno partnerstvo se splača}

Center odličnosti kot rizični kapital?

Gospodarstveniki od raziskovalcev največkrat pričakujejo samo pomoč pri reševanju obstoječih problemov, pobud za razvoj novih izdelkov pa je zanemarljivo malo - govorijo o podobnih stvareh, a v različnih jezikih

Delo, 7. maj 2010

Ljubljana - Konec prejšnjega leta je Slovenija dobila osem novih centrov odličnosti (CO). Ti delujejo kot konzorciji podjetij in raziskovalnih institucij. Med njimi je Center odličnosti nizkoogljične tehnologije (CO NOT), ki je včeraj v prostorih Kemijskega inštituta (KI) organiziral okroglo mizo, kjer so ugotavljali, kako (ne)učinkovito sodelujeta naše gospodarstvo in raziskovalno področje. Razprava je na to dala vsaj približen odgovor, ki ga je že v uvodu nakazal direktor CO NOT, prof. dr. Miran Gaberšček.

Gaberšček je povedal, da naše gospodarstvo od raziskovalcev največkrat pričakuje samo pomoč pri reševanju obstoječih problemov. Pobud za razvoj novih izdelkov pa je zanemarljivo malo. Direktor CO NOT je omenil primer laboratorija KI, ki je pred kratkim prodal patent, vendar kupcu iz Nemčije. Po drugi strani pa je v njihovem centru odličnosti že več projektov, ki jih vodijo podjetja, in v enem od njih tudi razvijajo nov izdelek. Poleg teh obetavnih začetkov Gabrščkov "zmeren optimizem" spodbujajo tuji zgledi mrežnih povezav razvojnih partnerjev, ki so se obdržale tudi po koncu proračunskega financiranja.

V razpravi je prof. dr. Jadran Maček z ljubljanske fakultete za kemijo in kemijsko tehnologijo dejal, da bodo centri odličnosti pri nas očitno prevzeli vlogo rizičnega kapitala, o katerem »vsi govorijo, a ga nikjer 
ni«. Vrednost vložka znanja, ki se ga, kot je dejal, naša podjetja še ne zavedajo dovolj, je prikazal na primeru niklja, ki ima v nanodelcih neprimerno večjo ceno, kot jo ima v prvotni obliki. Alenka Avberšek, direktorica za zakonodajo in politike pri Gospodarski zbornici Slovenije (GZS), je opozorila, da GZS že leta ponavlja, da bi bilo pri nas bistveno več sodelovanja med gospodarsko in raziskovalno sfero, če bi obstajale ustrezne stimulacije na različnih ravneh. Dr. Edvard Kobal, direktor Slovenske znanstvene fundacije, je izrazil upanje, da bodo centri odličnosti pognali korenine in da bo z njihovo pomočjo $v$ Sloveniji več razvojnega javno-zasebnega partnerstva. Kobal je še povedal, da je pri nas nizka stopnja komunikacijske kulture in da imamo težave pri upoštevanju dogovorjenih pravil, kar se odraža tudi v odnosih med podjetji in raziskovalnimi institucijami. Tudi dr. Sašo Dolenc, urednik Kvarkadabre, je opozoril na težave s sporazumevanjem - ljudje iz gospodarstva in z raziskovalnega področja se pogosto slabo razumejo, govorijo o podobnih stvareh, vendar v različnem jeziku. Opozoril je na vlogo države, ki bi morala imeti največji interes, da poleg finančnih spodbud ustvari pravo družbeno ozračje, ki bo spodbujalo omenjeno sodelovanje.

Šele na koncu okrogle mize smo doživeli ekološko razpravo, ki je opozorila, da je to okroglo mizo organiziral center nizkoogljične tehnologije. Dr. Dušan Petrač, ugledni fizik slovenskega rodu iz ZDA, je opozoril na neskladje med spodbujanjem nizkoogljičnih tehnologij in novim objektom termoelektrarne v Šoštanju. Avberškova je dejala, da GZS podpira šoštanjski projekt, ker za zdaj ni drugih možnosti, da si Slovenija zagotovi zadostno energetsko neodvisnost.

\section{Ocenjevalni postopki}

Ocenjevalne postopke, kakršne raziskovalne agencije danes uporabljajo za izbiro projektov, je prva uvedla ameriška raziskovalna agencija National Institutes of Health (NIH), ki je še vedno eden izmed največjih financerjev znanosti. Ocenjevalni postopki se zgledujejo pri dveh standardnih izbirnih postopkih iz akademskega sveta - recenziranju znanstvenih publikacij in izbiranju predavateljev na univerzah oziroma habilitacijskih postopkih.

V samostojni Sloveniji je bil eden od prvih ukrepov novega ministra za znanost uvedba tekmovalnega modela za izbiranje projektov za financiranje. Raziskovalci so morali napisati predlog (večinoma tudi v angleškem jeziku), ministrstvo pa je zaprosilo še za mnenje recenzentov, 
ki so bili običajno izbrani na predlog prijaviteljev. Projekte so na podlagi recenzentskih ocen izbrali nacionalni koordinatorji, slovenski predstavniki raziskovalnih področij, organizirani v področne svete. Bolj ali manj enaki ocenjevalni postopki so se izvajali do leta 2004. Kakšne so bile slabosti tega postopka, kako se je modificiral v naslednjem obdobju, katere so bile glavne dileme, ki jih je porajal?

Transparentnost. Metodologije ocenjevanja oziroma poteka izbirnega postopka niso opredeljevali ne zakoni ne pravilniki. Leta 2005 je AR RS postopke ocenjevanja, ki so bili takrat neformalni, sistematizirala in jih začela objavljati hkrati z objavo razpisa. Seveda je trajalo kar nekaj let, da je ARRS postopke poenotila in tiste, ki so postali splošno veljavni, zapisala v pravilnikih. Tudi pravilnike za različne razpise je nato poenotila v enem dokumentu. Danes raziskovalci vnaprej natančno vedo, kako postopek teče in kaj je pomembno za uspešno prijavo.

Konflikt interesov. V analizi konflikta interesov, objavljeni v reviji Scientometrics (Južnič idr., 2010), smo si zastavili osnovno vprašanje: komu bi na izbranih razpisih uspelo, če bi namesto ocen tujih recenzentov in odločitev nacionalnih koordinatorjev oziroma mednarodnih strokovnih komisij upoštevali zgolj in samo uspešnost raziskovalcev v zadnjih petih letih glede na bibliometrijske kazalce in podatke o sodelovanju raziskovalcev $\mathrm{z}$ gospodarstvom? Teoretični preizkus, pri katerem smo povsem zanemarili vsebine posameznih projektov, je pokazal, da so bili rezultati za leti 2005 in 2008 primerljivi z dejanskimi, za leto 2002 pa so precej odstopali.

V letih 2005 in 2008 je bil že v veljavi postopek izbire, ki je pri odločitvah temeljil predvsem na oceni skupine odličnih tujih raziskovalcev. Ti so bili skrbno izbrani in s prijavitelji projektov niso smeli biti ne $\mathrm{v}$ zaposlitvenih ne $\mathrm{v}$ raziskovalnih stikih. Leta 2002 so projekte prav tako ocenjevali tuji strokovnjaki, odločitev o izbiri pa je bila v rokah nacionalnega koordinatorja, ki so mu bile te ocene zgolj v pomoč pri odločanju. Pri našem preizkusu se je pokazalo, da bi zgolj bibliometrijskotehnicistični kriterij skozi sito spustil manj kot polovico takrat izbranih raziskovalcev, v letih 2005 in 2008 pa je bilo takšnih kar dve tretjini. Čeprav so ti podatki seveda pomanjkljivi in ne morejo pravično zaznati vseh odlik posameznega raziskovalca, odražajo dejstvo, da bo raziskovalec, ki je v preteklosti že napisal in izpeljal odlične projekte, verjetneje pripravil nov odličen projekt. Tisto tretjino, ki je v poskusni evalvaciji rezultatov razpisov za leti 2005 in 2008 izpadla, lahko optimistično pri- 
pišemo mladim raziskovalcem, ki še nimajo veliko kilometrine in torej njihove odličnosti ni mogoče razbrati iz preteklega dela, kljub temu pa so prijavili dobre projekte. S študijo smo torej pokazali, da smo z izločitvijo konflikta interesov ocenjevalni postopek spremenili tako, da so v skoraj dvajsetih odstotkih dobili projekte drugi raziskovalci, to pa ni malo.

Bibliometrija. Prvi pomemben znanstveni članek iz bibliometrije je analiziral bibliografijo prijaviteljev in rezultate primerjal z recenzentskimi mnenji (Cole in Cole, 1974). V znatnem številu vlog je opazil velike razlike med obema ocenama in bibliometrijo predlagal kot pomembno orodje za pomoč pri ocenjevalnih postopkih. Od takrat so se bibliometrijske baze zelo izpopolnile in $\mathrm{v}$ večini držav postale pomembno orodje pri ocenjevalnih postopkih. Med obema pristopoma je ves čas potekala in še poteka tekma - v kolikšni meri lahko uporabimo bibliometrijo, na kaj moramo biti pri njej posebej pazljivi, na drugi strani pa seveda podobna vprašanja, ki veljajo za recenzentske ocene (Južnič idr., 2010). ARRS je skupaj z inštitutom informacijskih znanosti IZUM V okviru sistema SICR IS razvila enega najkompleksnejših sistemov za bibliometrijsko analizo. Pozitiven rezultat uporabe bibliometrijske analize je bil jasna standardizacija znanstvene odličnosti in relevance, posledično pa izjemen napredek v kvaliteti slovenske znanosti.

Postopek so spremljali tudi negativni učinki. Raziskovalci so se namreč osredotočili na objave, ki so prinašale največ točk, kar pa ni bilo vedno optimalno. V letih do 2010 so se prispevki pogosto drobili na krajše enote in objavljali v manj uglednih znanstvenih revijah. Vpeljava citiranosti kot pomembnega elementa bibliometrije ter dodelitev posebnega statusa objavam v najboljših revijah in monografijah $\left(A^{\prime}, A^{\prime \prime}, A^{1 / 2}\right)$ sta večino teh anomalij odpravili. Danes raziskovalci praktično na vseh področjih objavljajo članke v najuglednejših revijah; objave v zgornji četrtini najboljših revij ( $\left.A^{\prime}\right)$ so se med letoma 1992 in 2014 tako povečale s 50 na 90 odstotkov pokritosti področij - kultura objavljanja je postala primerljiva z uspešno Evropo. Uporaba bibliometrije se je zato omejila predvsem na preverjanje vstopnih pogojev za projektne vloge in vloge za mentorje mladih raziskovalcev ter na preverjanje minimalnih standardov članov programskih skupin.

Razmerje med različnimi tipi projektov. Ta element izbirnih postopkov je v javnih razpravah pogosto prezrt, a je pa po mojem mnenju najmanj toliko pomemben kot recenzentska ocena. ARRS pri vsakem razpisu na- 
pove približno število različnih tipov projektov (podoktorski projekti, projekti mladih doktorjev, temeljni, aplikativni, veliki, mali projekti), ki jih bo na posameznem področju podprla. To pomeni, da so v nekaterih primerih dobro ocenjeni predlogi lahko tudi zavrnjeni, predlogi skupin s povprečno slabšimi ocenami pa sprejeti. Optimalne rešitve tega problema ni, še najbližji ji je verjetno avstrijski model, ki ima pretežno institucionalno financiranje. Pri izbiranju se zato lahko opirajo izključno na recenzentske ocene, na število izbranih projektov za različne kategorije pa se ne ozirajo.

Kaj je je pomembnejše, reference prijavitelja ali vsebina projekta? Spominjam se pogovora z Nobelovim nagrajencem prof. Haroldom Walterjem Krotom, ki je trdil, da je za znanstvenike primeren izključno institucionalni način financiranja, reference prijavitelja pa edini kriterij pri dodelitvi teh sredstev. Zanimivo, sem rekel, raziskovalci s področja tehnike pa trdijo ravno obratno. Seveda, jaz govorim o naravoslovju, je odvrnil, raziskovanje v tehniki pa je bolj aplikativno usmerjeno, tam je treba upoštevati predvsem vsebino projekta.

Pri izboljševanju ocenjevalnih postopkov je ves čas aktivno in tudi kritično sodelovala strokovna javnost, in to tako neformalno (prek medijev, simpozijev, okroglih miz) kot formalno prek znanstvenih svetov agencij, ki so zadolženi za dopolnjevanje ocenjevalnih postopkov. Leta 2000 je izšla tudi publikacija E S F - pri njenem nastanku je sodelovala tudi ARRS (European Science Foundation, 2011a) -, ki se posebej posveča podrobnemu analiziranju dilem in predstavljanju uspešnih praks. A z ocenjevalnimi postopki je povezanih še kar nekaj dilem, zato se bodo brez dvoma še dopolnjevali.

\section{Zgrešeno programsko financiranje}

Delo, 14. februar 2013

Uspešni raziskovalec dr. Jernej Zupanc je eden najsamozavestnejših mladih mož, kar sem jih kdaj srečala v slovenski znanosti. Govori brez dlake na jeziku. To je dokazal tudi na zadnji seji sveta za znanost in tehnologijo (SZ T), kamor ga je povabil prof. dr. Roman Jerala.

Dr. Zupanc je ob omenjeni priložnosti vzbudil pozornost s svojo nazorno predstavitvijo razlogov, zaradi katerih pri nas izgubljamo najbolj izobražene in nadarjene raziskovalce. Po njegovih besedah imamo pri nas na eni strani zelo obsežen sistem podpore doktorskemu študiju, 
povsem drugače pa je ob koncu doktorata. Takrat zanje skoraj ni delovnih mest, prav tako so minimalne možnosti, da se mladi raziskovalci po doktorskem študiju vključijo v projekte in si s tem zagotovijo preživetje na začetku kariere.

"Sposobnosti ljudi znotraj vsake generacije so približno enako porazdeljene. Zato bi bilo treba zagotoviti, da so proračunskega financiranja deležni najbolj izjemni med njimi. Pri nas tega ravnotežja ni. Stare generacije so si priskrbele stalno financiranje, ki se jim ga skoraj ne da vzeti - tudi če iz njihovega raziskovanja ni rezultatov, "je bil na seji SZT oster dr. Zupanc, v pogovoru za Na poti do diplome pa je ta svoja stališča, ki jih menda deli s številnimi vrstniki iz raziskovalne sfere, podrobneje pojasnil.

Kot pravi, gredo mladi $v$ doktorski študij iz različnih razlogov. »Nekateri se za ta študij odločijo preprosto zato, ker ne najdejo dela. V tem primeru ima ta študij vlogo socialnega korektiva, kar verjetno ni njegov namen. Vsekakor je status mladega raziskovalca eden najboljših statusov, ki ga lahko v slovenski znanosti dobiš takoj po diplomi. Si zaposlen, tvoj študij je zate brezplačen, imaš denar za raziskave, lahko potuješ... $V$ moji generacija so bila za doktorski študij na voljo štiri leta in pol, zdaj pa leto manj, kar verjetno negativno vpliva na kakovost doktoratov. Dostop do statusa mladega raziskovalca je precej omejen - na leto ga lahko zdaj dobi okrog 160 diplomantov, kandidatov pa je bistveno več. Pri nas obstajajo še druge možnosti za državno financiranje doktorskega študija. S tem mislim predvsem na inovativne sheme, kjer doktorski študij letno financiramo še dodatnim 600 do 700 doktorandom."

Zaradi vsega tega se je, pravi Zupanc, število doktorskih študentov zelo povečalo. »Leta 2004 jih je bilo samo okrog tisoč, leta 2011 pa že več kot 4.0oo. Glede na to, da je število potencialnih mentorjev v vsem tem času ostalo približno enako, sam resno dvomim, da je enako kakovosten ostal tudi doktorski študij.“

Slabši del pride pozneje. "Obstaja prepad med doktorskim študijem in med tistim, kar pri nas pripada predvsem starejši generaciji raziskovalcev. Četudi je zaželeno, da se po doktoratu raziskovalci nekaj let izpopolnjujejo v tujini, sistem slovenskega financiranja znanosti ni naklonjen njihovi vrnitvi. "Razloge za omenjeno neskladje Zupanc vidi predvsem v obstoječem programskem in projektnem financiranju. »Mlajšim so na razpolago dejansko samo projekti, ki jih je zadnje čase vedno manj, do njih se je treba prebiti skozi ostro konkurenco, začetek financiranja pa se odlaga dolge mesece. Pri zadnjem razpisu v letu 2011 je bilo prija- 
vljenih 752 navadnih projektov in 274 podoktorskih, izbran pa je bil le približno vsak deseti. V letu 2012 zaradi varčevanja na primer sploh ni bilo razpisa za projekte. S tako ostro selekcijo za razdeljevanje javnega denarja sicer ne bi bilo nič narobe, če ne bi obstajal tudi vzporeden, veliko manj selektiven način. Temu drugemu se pri nas reče programsko financiranje, do njega raziskovalci, mlajši od 45 let, tako rekoč nimamo dostopa. Programe, katerih vrednost je letno več sto tisoč evrov, skupaj pa obsegajo skoraj tri odstotke proračuna ARRS, že dolgo držijo isti starejši raziskovalci.«

Zupanc poudarja, da so programi nastali leta 1999. Zaradi želje po stalnem financiranju znanosti so nekatere takratne tekoče projekte spremenili $v$ programe. "Osebno se seveda strinjam z obstojem programov, saj mora obstajati neka kontinuiteta. Ne strinjam pa se s tem, kako se ta izvaja. Po prvotni razdelitvi so programi večinoma ostali zaprti in do njih ne pride nihče z novim programom, ki bi konkuriral tekočim. Nov bi se lahko uveljavil hipotetično, če bi kakšen program ukinili. To pa se tako rekoč nikoli ne zgodi. Na zadnjem razpisu za financiranje je bilo podaljšanih 59 izmed 60 programov! Ocene se upoštevajo le pri podaljševanju programa: ̌̌e so ocenjeni kot odlični, so financirani za šest let, če pa so ocenjeni zelo slabo, za tri leta. Pri tem je tudi postopek recenzije programov manj rigorozen kot pri projektih."

Naš sogovornik sicer vidi rešitev: »V prihodnjih letih bi morali na novo oblikovati programe, za nosilce katerih bi se lahko prijavili vsi slovenski znanstveniki, predvsem tisti, ki jih zdaj po doktoratu >naganjamo $v$ tujino. Pred tem se moramo dogovoriti za smernice, na podlagi katerih bomo znanost prioritetno financirali. Tako bomo ohranili prioritetno kontinuiteto, hkrati pa imeli sodobne programe, ne pa petnajst let starih. S tem bomo dosegli, da jih bodo vodili dejansko najboljši ljudje, in ne zgolj tisti, ki so bili zraven pri njihovem nastanku."

Dr. Zupanc je odgovoril tudi na naše vprašanje, kaj misli o napovedi resornega ministra Žige Turka, da bodo z delom dodatnih proračunskih sredstev podprli mlade raziskovalce. »Ta napovedana finančna injekcija se mi zdi zgolj obliž na rano. Bolje bi bilo, če bi se zadev lotili sistemsko in pri tem ustrezno uporabili instrumente, ki so že na voljo $v$ naši javni raziskovalni agenciji.«

Raziskovalec, ki je nedavno stopil v tretje desetletje, se prišteva kipsilon generaciji. „Ta generacija je prehodna, soočena je s tem, da so se pravila, ki so veljala in s katerimi smo mi odraščali, veljala pa so tudi za našo vzgojo in izobraževanje, v zelo kratkem času zlomila. Nastal je 
divji zahod, ki se zaenkrat starejših veliko manj dotakne kot nas. Zdaj $v$ družbi veljajo nova pravila, ki se jim mladi prilagajamo. Na nek način smo veliko bolj sami odgovorni za svojo usodo, kar pa ni nujno le slabo."

Morda bo dr. Jernej Zupanc kdaj pri tem še aktivneje sodeloval kot doslej, saj ne skriva, da ga zelo mika znanstvena politika. »To je področje, kjer se sreča mnogo interesov. Zdi se mi potrebno, da nekdo, ki od blizu doživlja te stvari, nanje opozori tudi širšo javnost.«

\section{Spodbujanje sodelovanja z gospodarstvom in drugimi deli družbe}

Slovenija je po osamosvojitvi nadaljevala s proračunskim podpiranjem aplikativnih projektov, ki je še danes pomembna oblika financiranja $\mathrm{v}$ okviru ARRS. Iz slike 3.5 na strani 54 lahko razberemo, da se je sodelovanje znanosti in gospodarstva $\mathrm{v}$ Sloveniji $\mathrm{v}$ zadnjem desetletju zelo okrepilo, za kar si je ARRS tudi prizadevala. Grafikon na sliki 3.5 sestavljajo podatki iz ocenjevalnega elementa A3, ki od leta 2005 beleži sredstva vseh slovenskih raziskovalcev (iz gospodarstva, E U, ministrstev, ki niso zadolžena za znanost). Ti podatki o vpetosti raziskovalca v širše družbeno okolje, ki jih pridobi ARRS, so eno od meril pri vstopnih pogojih za prijavo na projekte in pomemben element nagrajevanja programskih skupin.

Leta 1994 je ministrstvo za znanost razvilo program ciljnih raziskovalnih projektov (CRP), ki združuje finančne vire tistih ministrstev, ki jih zanimajo predvsem ekspertne znanstvene raziskave $s$ področij kmetijstva in družboslovja. Program je bil med drugim zasnovan, da bi zmanjšal razdrobljenost znanstvenega delovanja na posamezne projekte in jih med seboj povezal $\mathrm{v}$ bolj organiziran znanstveni sistem, vendar bi težko trdili, da je zares dosegel svoj namen. Značilnost programa CRP je usmerjenost v uporabne, za državo pomembne raziskave, saj gre za financiranje tematik po izboru ministrstev, ki glede na svoje potrebe same izberejo tudi predloge. Program je doživel več faz; danes ARRS preverja izpolnjevanje vstopnih pogojev oziroma strokovno usposobljenost vodij projektov, pri izbranih projektih pa sodeluje kot sofinancer. $\mathrm{Na}$ ta način se financirajo tiste raziskave, ki so v interesu države, obenem pa je zagotovljena tudi kvaliteta projektov.

Največ sredstev je bilo za C R P namenjenih v letih 2006, 2007 in 2008, ko je bil njihov glavni sofinancer Ministrstvo za obrambo, ki je v okviru tega programa prispevalo okoli pet odstotkov celotnih sredstev za fi- 
nanciranje slovenske znanosti. Projekt je uspešno združil dva cilja: povečal je odstotek sredstev za obrambne izdatke, kar je bila naša zaveza ob vstopu v NATO, in hkrati povečal sredstva, ki so bila na razpolago našim raziskovalcem. Omogočil je tudi pomembne povezave v okviru Evropske obrambne agencije, saj je naše financiranje sledilo njihovim prioritetnim temam.

\section{Znanost mora tvegati}

Delo, 7. maj 2010

Včeraj in predvčerajšnjim smo lahko $v$ Sloveniji na dveh razpravah poslušali predloge, kako s pomočjo raziskovalne sfere izboljšati slovensko konkurenčnost. Včeraj so o tem govorili na okrogli mizi centra odličnosti nizkoogljične tehnologije na Kemijskem inštitutu, dan prej pa na svetu za znanost in tehnologijo (SZ T). NI šlo samo za različne ravni razprav, ampak tudi za različnost filozofij. Na Kemijskem inštitutu so optimistično ugotavljali, da skupno delo podjetij in raziskovalnih institucij že na začetku kaže obetavne rezultate in nakazuje, da bodo centri morda preživeli čas financiranja iz slovenskega in evropskega proračuna.

Na seji SZT v sredo pa je premier Borut Pahor poskušal prepričati člane sveta, da jih vlada prav zdaj »krvavo potrebuje«, vendar ne za dolgotrajno pripravo razvojnih dokumentov, temveč za takojšnjo pripravo predlogov, s katerimi konkretnimi ukrepi bi lahko že v kratkem času povečali inventivnost našega gospodarstva, pritegnili tuja perspektivna podjetja in tako Sloveniji zagotovili položaj v skupini razvojno perspektivnih držav Unije. Čeprav je Pahorja v poznejši razpravi podprlo kar nekaj članov sveta, pa očitno ni prepričal avtorjev razvojnih referatov. Predsednik SZ T Marko Jakličje premiera poučil, da je odločanje naloga politike, in ne sveta, zato SZT tudi nihče ne more siliti k naglici.

Tisti, ki že vrsto let spremljamo vladni odnos do domače znanosti in tehnologije, sicer dobro vemo, da se še nobena vlada ni branila vtisa, da njeni razvojni dokumenti temeljijo na znanosti. Toda verjetno ne tvegamo veliko, če rečemo, da še noben predsednik vlade ni, tako kot zdaj Pahor, zagotovil, da bodo vsi vladni resorji upoštevali tisto, kar jim bo naročila znanost. Tako rekoč sanjski scenarij pa ima - pa s tem ne trdimo, da je bil prav to razlog za Jakličevo zaviranje Pahorja - veliko pomanjkljivost. Znanost bi tako postala soodgovorna za vladno razvojno politiko. Kaj pa, če se bi nazadnje pokazalo, da predlagani ukrepi ne bi prinesli želenih razvojnih sprememb? Je pa uglednežem iz SzT že bolje 
še naprej pisati dolgoročno naravnane razvojne predloge in se jeziti na slabe politike, naše neustrezne predpise in zakone ali pa na lizbonsko strategijo.

Med neuradnim kramljanjem na eni od teh razprav smo slišali tudi, vsaj sprva, čudaško vprašanje: Kaj imajo skupnega molotovke na grških ulicah in lizbonska strategija Unije? Odgovoru, da prav ničesar, bi lahko dodali, da grška tragedija odseva neučinkovitost omenjenega evropskega dokumenta. Kajti tako poveličevan dogovor med članicami EU o ukrepih, s katerimi naj bi Unija po prvotnem dogovoru že do leta 2010 postala najbolj konkurenčno, dinamično in na znanju temelječe gospodarstvo na svetu, se je že po nekaj letih pokazal kot najmanj časovno utemeljen projekt, danes pa kljub podaljšanemu roku vanj pravzaprav verjame samo še Evropska komisija.

Kot vemo, so lizbonski dogovor izpolnjevale predvsem članice, ki so bile že prej razvojno naravnane, druge pa so v letih Lizbone samo še bolj zaostale, kar se je izrazito pokazalo $v$ času recesije in končno eksplodiralo na grških ulicah ... Očitno si lahko Slovenija varno prihodnost zagotovi samo, če tvega razvojni preboj in s tem ostane v družbi uspešnih. Znanstveniki imajo zdaj priložnost, da res naredijo nekaj velikega, ne da bi se jim bilo zato treba neposredno vključiti v visoko politiko. Dati morajo samo to, kar jim menda gre najbolje - nove ideje. Tveganje pa bodo tako ali tako delili z vsemi nami. 



\section{Znanstvena odličnost}

Rezultat se pri večini človeških dejavnosti veže na količino opravljenega dela, pri znanosti pa je na prvem mestu kakovost raziskovalnega dela. Znanstvena odličnost zato igra odločilno vlogo pri razvoju znanosti, kar seveda velja tudi za slovensko znanost. V svetu ni nikakršne dileme, ali dati prednost znanstveni odličnosti ali aplikativnosti, v Sloveniji pa se na to temo neprestano razplamtevajo razprave. Ključni tehnološki preboji so vedno povezani z odlično znanostjo, nikoli s povprečnostjo. Tudi za raziskovalce, ki se posvetijo aplikativnim področjem, je takšno izhodišče zelo pomembno. Zanimiv je podatek, da se prodorne znanstvene raziskave v Sloveniji opravijo tudi v okviru gospodarskih družb, tako kot je sicer marsikje po svetu.

Kako je s slovensko znanstveno odličnostjo? Najbolje, da pri tehtanju odgovora uporabimo uveljavljene mednarodne primerjave - znanstvene objave in citiranost. Pri tem moramo imeti v mislih, da znanstvena odličnost vsebuje izvrstnost, prebojnost, vrhunskost znanstvenih vsebin, odkritij in novosti, ki pa se jih resda meri glede na znanstvenikovo bibliografijo: štejeta številčnost objav in mednarodni ugled revij oziroma znanstvenih založb, kjer so objave izšle, enako pa velja tudi za citate. Odmevnost večinoma sovpada $z$ odličnostjo, a ne povsem, saj je uporaba bibliometrije kot merila za izbiro projektov vplivala tudi na raziskovalce, ki so se ji začeli prilagajati, da bi dosegli čim boljše rezultate.

Slovenija je bila do leta 1991 na področju znanosti razmeroma zaprta država, število objav, ki jih beleži mednarodna baza Web of Science (wos) z obravnavo okoli 14.000 znanstvenih revij z vsega sveta, je takrat dosegalo približno polovico evropskega povprečja, če podatke normiramo po številu prebivalcev. V zgolj 25 letih se je to število povzpelo na dvakratnik evropskega povprečja. Število objav v revijah, indeksiranih v w O s, je začelo rasti takoj po letu 1991, kar deloma res lahko pripišemo tudi psihološkemu učinku samostojnosti in večje odprtosti (Južnič in Santos, 1993). Vsekakor pomeni objava v reviji, ki je uvrščena $v$ bazo wos, pomemben znak kvalitete, a v razvitem znanstvenem sve- 


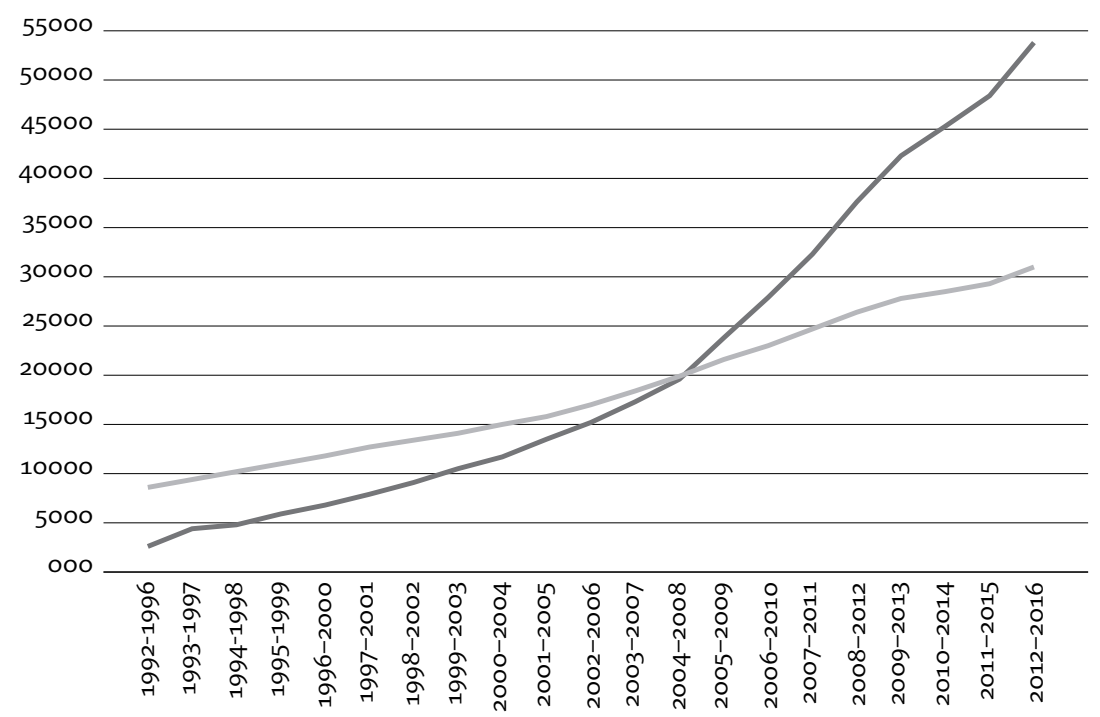

Slika 5.1 Primerjava citiranosti znanstvenih člankov za Slovenijo in E U-28 iz baze wo s

Število citatov na milijon prebivalcev. Temno - Slovenija, svetlo - E U-28. Po podatkih ARRS (https://www.arrs.gov.si/sl/analize/odlicnost).

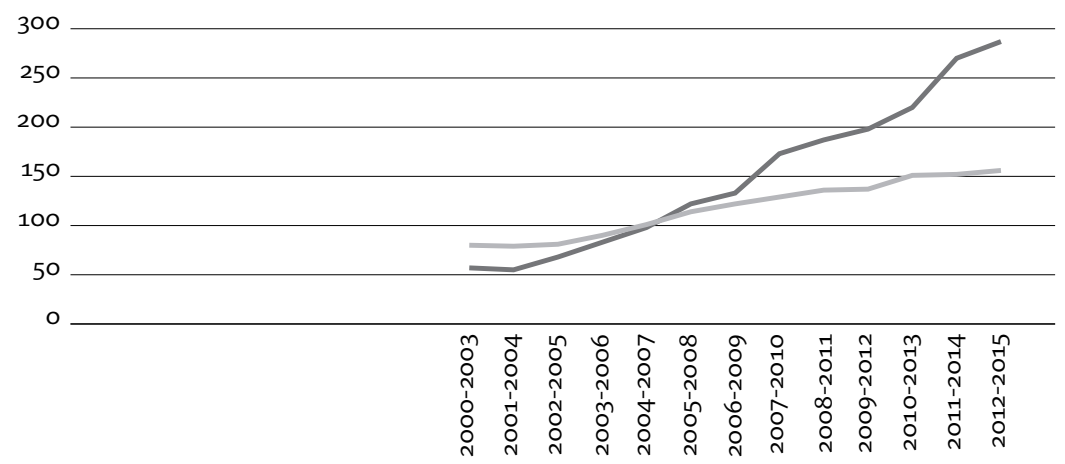

Slika 5.2 Število najodmevnejših člankov (10\% najbolj citiranih) na milijon prebivalcev v E U in Sloveniji iz baze Scopus

Temno - Slovenija, svetlo - EU-28. Po podatkih ARRS (https://www.arrs.gov.si/sl/ analize/odlicnost).

tu to velja tudi za predpogoj znanstvene odličnosti. Več od same objave pove odmevnost znanstvenih člankov oziroma njihova citiranost. $\mathrm{Na}$ začetku samostojne Slovenije so bili na tem področju rezultati še slabši od števila objav: povprečna citiranost slovenskih člankov je pred 25 leti 


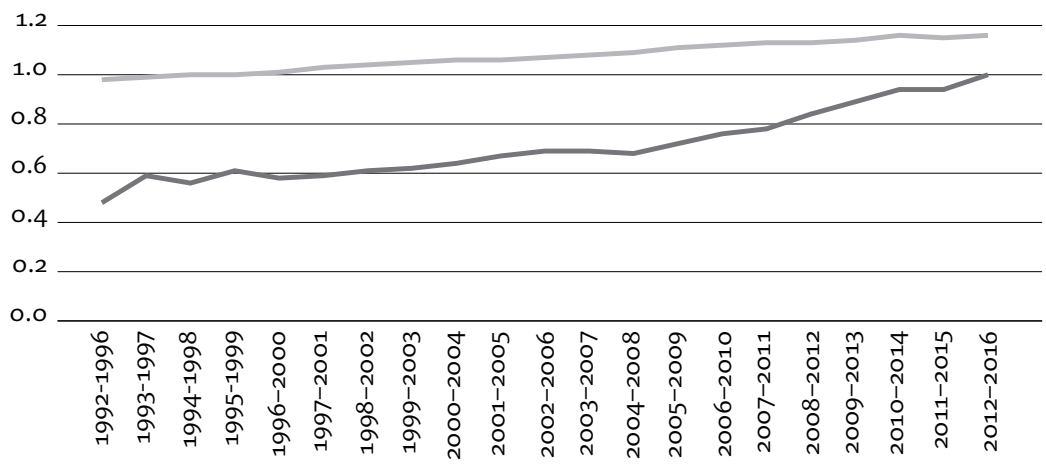

Slika $5 \cdot 3$ Povprečna citiranost člankov (citati na članek) za E U in Slovenijo iz baze wos

Temno - Slovenija, svetlo - EU-28. Po podatkih ARRS (https://www.arrs.gov.si/sl/ analize/odlicnost).

dosegala komaj tretjino evropskega povprečja, medtem ko danes predstavlja 150 odstotkov evropskega povprečja. Slika 5.1 na prejšnji strani kaže rast citiranosti slovenskih člankov v primerjavi z E U.

$\mathrm{Na}$ rezultate citiranosti slovenskih znanstvenih člankov smo lahko zelo ponosni. Kot vidimo na sliki 5.2 na prejšnji strani (podatki so sicer dostopni samo od leta 2000), so podobni rezultati tudi za število slovenskih znanstvenih člankov, ki sodijo v zgornjo desetino najbolj citiranih člankov.

Celo delež slovenskih znanstvenih člankov, ki so se uvrstili med en odstotek najbolj citiranih člankov v najodmevnejših znanstvenih publikacijah, je podoben in seveda navdušujoč.

Vendar pa podatki, ki upoštevajo relativni faktor vpliva (razmerje med citati in številom člankov za Slovenijo glede na ta koeficient v mednarodnem merilu), kažejo na nenavadno anomalijo slovenskega znanstvenega raziskovanja. Na eni strani Slovenija beleži visoko citiranost najboljših del, na drugi pa veliko število malo ali nič citiranih člankov, kar se odraža $v$ razmeroma nizkem relativnem faktorju mednarodnega vpliva (slika 5.3).

Glavni razlog za nizki relativni faktor je že omenjeno nadpovprečno veliko število nikoli citiranih niti avtocitiranih znanstvenih člankov (43\%). To dejstvo kaže na razdrobljenost znanstvenega raziskovanja $\mathrm{v}$ Sloveniji, preveliko število objav in drobljenje raziskovalnih rezultatov. Predvsem za člane programskih in projektnih skupin je povsem nesprejemljivo, da članki, ki jih objavijo njihovi člani, niso med seboj povezani 
(avtocitirani). Odsotnost avtocitiranosti je samo eden od znakov omenjene problematike, do katere prihaja zato, ker raziskovalci v projektni skupini med seboj niso dovolj povezani. Dobre rezultate pri projektni skupini namreč lahko prinese le poglobljeno raziskovanje, ki pa je rezultat medsebojnega sodelovanja in skupnih prizadevanj pri izbrani tematiki.

Drugi razlog je v nedoslednem navajanju ustanov $\mathrm{v}$ primeru soavtorstev, saj precejšnje število slovenskih raziskovalcev v člankih, ki so plod raziskav, povezanih $\mathrm{z}$ njihovim gostovanjem $\mathrm{v}$ tujini, ne navaja svoje matične slovenske ustanove. Matična država oziroma raziskovalna ustanova za raziskovalce očitno ni referenčna. Takšnih člankov je po naši oceni do 10 odstotkov in so v povprečju med bolj citiranimi.

Izjemna rast znanstvene odličnosti v Sloveniji je, še posebno v zadnjem desetletju, rezultat koordiniranih ukrepov znanstvene politike. To je poudarila tudi revija Nature, ki je v prispevku o znanosti v vzhodnoevropskih državah 25 let po padcu berlinskega zidu citirala mojo izjavo: "Znanstveniki so se morali naučiti, da so zdaj znanstveni rezultati edini kriterij pri zagotavljanju sredstev za raziskovanje. To je bil težaven proces, ki pa je znanosti v tem delu sveta prinesel velik napredek." (Abbott in Schiermeier, 2014) A R R S je uvedla ocenjevalne postopke, pri katerih sodelujejo samo ugledni tuji raziskovalci, ki so precej prevetrili slovenski znanstveni prostor. Nanj so vplivali s svojimi standardi kvalitete, obenem pa se je $\mathrm{z}$ njimi razrešil konflikt interesov in s tem bistveno izboljšal ocenjevalni postopek. AR R S je pri vstopnih pogojih vedno upoštevala kriterije znanstvene odličnosti, tako kvaliteto revij, v katerih so objavljeni prispevki, kar spodbuja ambicioznost raziskovalcev, kot citiranost objav, ki odličnost nadgrajuje.

\section{Zmagovita enačba?}

\section{Delo, 6. maj 2011}

Predlanskega septembra sem bila s skupino evropskih znanstvenih novinarjev na obisku Helmholtzovih inštitutov v Nemčiji, med katerimi je bil tudi raziskovalni center Karlsruhe (Forschungszentrum Karlsruhe). Toda ob imenu centra in vsakega od njegovih inštitutov se je pojavljala tudi kratica KIT. Pojasnili so nam, da se omenjeni raziskovalni center povezuje s tamkajšnjo univerzo $v$ skupno institucijo KIT - Tehnološki center Karlsruhe. Le nekaj dni za tem, z oktobrom 2009, je uradno obstajal samo še KI T, kar pomeni, da sta svoji dotedanji imeni po skoraj tri 
leta nastajajoči združitvi izgubila oba, ugledna raziskovalna univerza in nič manj ugledni raziskovalni inštitut. In kaj sta z združitvijo pridobila? KIT je zdaj eden največjih izobraževalno-raziskovalnih centrov $v$ Evropi, ki skupno zaposluje okoli 8000 ljudi. Za več kot 20.000 študentov pa je pomemben še podatek, da je KIT že v tem kratkem času izjemno napredoval na lestvicah najboljših univerz. Po merilih EU se med tehniškimi univerzami uvršča na drugo mesto $v$ Nemčiji in med prvih deset $v$ Uniji. S slovenskega zornega kota je skoraj nepredstavljiv tudi proračun KIT, saj presega 700 milijonov evrov. Toda Nemčija, ki se je že otresla gospodarske krize in ki že nekaj let zagrizeno ustvarja odlične univerzitetne in raziskovalne centre, bo svojo naložbo $v$ ta mastodont verjetno hitro upravičila.

Zakaj to omenjam? Zato, ker je na začetku letošnje pomladi že kazalo, da bo tudi Slovenija dobila nekaj, kar bi lahko pogojno primerjali s KIT, če že ne z velikim ameriškim vzornikom MIT. Ljubljanska univerza je, kot je takrat zelo jasno povedal njen rektor - celo izjavo lahko preberete v prispevku na tej strani -, želela s pridružitvijo štirih največjih raziskovalnih inštitutov izboljšati svoje mesto na lestvici najboljših evropskih in svetovnih univerz, inštitutski raziskovalci pa bi s tem dobili priložnost za enakopravno sodelovanje v doktorskih študijih. Seveda bi se bilo z združitvijo večinskega dela raziskovalcev in raziskovalne infrastrukture $v$ prestolnici bistveno lažje vključiti v velike mednarodne raziskovalne projekte. Univerzi in inštitutom pa bi ob tem ostala tako rekoč vsa avtonomija, tudi sedanja imena, morda bi jim inštituti dodali le kratico UL.

Zdajje že jasno, da te univerzitetno-inštitutske simbioze pri nas še ne bo, je pa že nastala drugačna, namreč konzorcijska naveza prav tistih inštitutov, ki jih je vabila ljubljanska univerza. Zakaj niso zagrabili za trnek univerze, ki bi ga verjetno pred nekaj leti navdušeno sprejeli? Zdi se, da še dvomijo o svoji enakopravnosti v okviru univerze, za kar imajo verjetno nekaj tehtnih argumentov, med drugim vidnih iz prispevka na tej strani, v katerem pišemo o konzorciju. Odločilno za (začasni) ne snubitvi univerze pa je bržkone to, da lahko inštituti svoj poglavitni cilj, izvajanje doktorskega študija, uresničijo tudi brez univerze, saj jim to omogoča predvčerajšnjim sprejeta resolucija o nacionalnem programu visokega šolstva.

Vprašanje, zakajje inštitutski konzorcij nastal celo prej kot resolucijski okvir zanj, verjetno zdaj sploh ni več bistveno. Morda le še za tiste, ki bi želeli v tem najti politično ozadje. Konzorcij je pač jagoda na torti 
zmagoslavja avtorjev obeh omejenih sprejetih resolucij na ministrstvu za visoko šolstvo, znanost in tehnologijo, otipljiv dokaz, da resoluciji delujeta.

A ker gre za dolgoročno usmerjen konzorcij, se je treba tudi vprašati, kaj bo z njim čez pet ali deset let. Morda bo čez čas konzorcij, če se bo prijel in če bo pokazal pričakovani učinek, postal pravna oseba. Morda bo do tedaj načrtovana konzorcijska podiplomska šola prerasla $v$ novo raziskovalno univerzo. Morda bo to res naš LI T - ljubljanski tehnološki inštitut, morda bo iz njega dotlej izšlo že na desetine spin-off podjetij. Karkoli že bo ali ne bo, najslabša možna posledica konzorcija bi bile še bolj sprte univerze in inštituti. Kar bi se najlažje zgodilo, če ne bo napovedanega velikega povečanja javnih sredstev za raziskave in razvoj ter seveda tudi za visoko šolstvo. Scenarija neusmiljenega boja za isto napol prazno vrečo javnih sredstev izpred nekaj let se verjetno še vsi dobro spominjajo. Vendar verjemimo vladi, ki pravi, da bo zdaj zares več denarja. 


\section{Slovenski inovacijski sistem}

Kakšna je povezava med vlaganji v raziskave in indikatorji razvitosti družbe? Premo sorazmerna - odgovor daje slika 6.1 na naslednji strani. E U si je leta 2000 zato $\mathrm{z}$ lizbonsko strategijo postavila cilj, da se gospodarstvo v okviru EU do leta 2010 tesneje poveže z znanostjo. Kot enega od ukrepov, $s$ katerimi bi to dosegli, je predvidela dvig vlaganj $\mathrm{v}$ R R V E U, in sicer na tri odstotke B D P do leta 2010 (European Council, 2000).

Današnje številke evropskih vlaganj v raziskave in razvoj se glede na delež B D P gibljejo do nekaj procentov, odvisno od države, nikjer pa ne presežejo pet odstotkov. Toda ali je tako skromen tudi vpliv, ki ga imata raziskovanje in razvoj na družbo? Seveda ne; znanstvena odkritja imajo ne nazadnje neposreden vpliv na tehnologije, ta pa na gospodarstvo in družbo na splošno. Slika 6.1 na naslednji strani nazorno kaže, da imajo države, ki več vlagajo v znanost oziroma v raziskave in razvoj, višji B D P na prebivalca in so torej bolj razvite.

Na grafu so predstavljene države EU-28 in njihovo povprečje v dveh letih, leta 1995 in leta 2014. Začetek puščice predstavlja leto 1995, konec puščice leto 2014. Na vodoravni osi je višina vlaganj v raziskave in razvoj, na navpični osi B DP na prebivalca. Iz grafa je razvidno, da več ko države vlagajo v raziskave in razvoj, bolj so razvite (višji B D P). Med njimi se najdejo tudi izjeme, kot je denimo Luksemburg (ni na sliki), ki je majhna država, specializirana za finančne storitve, ki jih opravlja predvsem za sosednje države. Če na grafu preverjamo, kaj se zgodi v dvajsetletnem obdobju, ugotovimo, da se povečanje vlaganj v R R ne odraža pri vseh državah enako - pri nekaterih je učinek vlaganja v R R zelo opazen, pri drugih pa manj. Če bi v pregled vzeli krajše obdobje, recimo zadnjih pet let, ki jih je zaznamovala finančna kriza, potem bi za nekatere države dobili drugačno sliko, na primer povečanje vlaganja $v R R$ in obenem padec BDP.

$\mathrm{V}$ obeh primerih lahko sklepamo dvoje. Prvič, vlaganja v raziskave in razvoj so dolgoročna usmeritev in neizpodbitno vplivajo na B D P. Dru- 


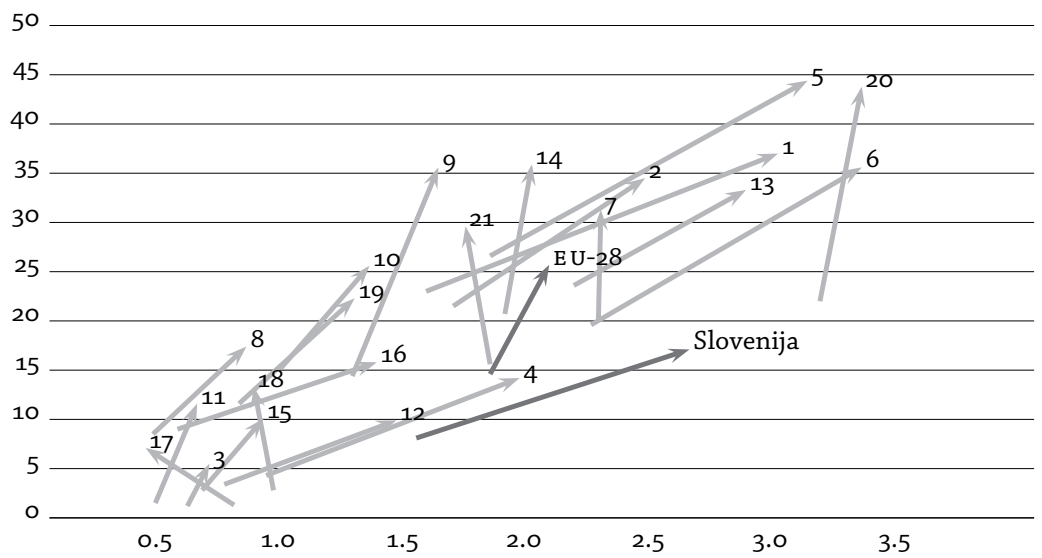

Slika 6.1 Primerjava med B DP na prebivalca in vlaganji $v R R$

Ordinata - B DP na prebivalca (v 1000 EUR), abscisa - vlaganja v RR v odstotkih B DP. Začetek puščice - 1994, konec puščice - 2014. Države: 1 - Avstrija, 2 - Belgija, 3 - Bolgarija, 4 - Češka, 5 - Danska, 6 - Finska, 7 - Francija, 8 - Grčija, 9 - Irska, 10 - Italija, 11 Latvija, 12 - Madžarska, 13 - Nemčija, 14 - Nizozemska, 15 - Poljska, 16 - Portugalska, 17 - Romunija, 18 - Slovaška, 19 - Španija, 20 - Švedska, 21 - Velika Britanija; za druge države EU nimamo podatka za leto 1995. Podatek o višini BDP za EU-28 je povzet po sliki 3.1 na strani 44. Po podatkih Eurostata (http://ec.europa.eu/eurostat).

gič, na B D P vpliva še veliko drugih dejavnikov, R R pa je le eno od kolesc, ki poganjajo delovanje države.

Kaj v okviru grafikona lahko razberemo o Sloveniji? Njen B D P se je v dvajsetih leti zelo povečal, vendar je ostal pod evropskim povprečjem, še bolj pa so se povečala sredstva, namenjena vlaganju v RR, ki so se dvignila celo nad evropsko povprečje. Zasluge za takšno povečanje ima predvsem gospodarski delež vlaganj v R R. Kaj je razlog za to, da se Slovenija ne razvija hitreje? Če hočemo na vprašanje odgovoriti, moramo najprej dognati, kakšen je izkoristek slovenskih vlaganj v RR, kar poskušamo tudi v tej knjigi, in kako učinkovito je pri tem delovanje drugih družbenih podsistemov.

\section{Kdaj naš prevod finske pravljice?}

Delo, 8. maj 2004

V zadnjih nekaj mesecih smo lahko tako rekoč na vseh ravneh slišali pozive, naj se Slovenija razvojno zgleduje po Finski, oziroma ugotovitve o tem, da jo že posnemamo. Pred tem je bila kot naša vzornica navadno omenjana Irska, ki v tej vlogi sicer še vedno ostaja, a je zdaj zdrknila 
na drugo mesto. Finska je preprosto »in«. V znanosti, v izobraževanju, $v$ gospodarstvu. Ali se zgledujete po Finski ali pa je z vašo razvojno naravnanostjo nekaj narobe...

$\mathrm{Ne}$, nočem ironizirati malikovanja finskega razvojnega čudeža. Kajti ta čudež nedvomno obstaja - v nasprotju z drugimi čudeži se ga da $z$ znanstveno natančnostjo izmeriti, popisati, si ga prav od blizu ogledati. Tako kot smo si ga ogledovali mi, ki smo spremljali našega predsednika med obiskom na Finskem. In Finci so se na slovensko zvedavost in neštetokrat ponovljeno priznanje, da jih Slovenci občudujemo in si jih želimo posnemati, odzvali s prav nič severnjaško zadržano ljubeznivostjo.

Seveda - so dejali - prav radi povedo vse o svojih razvojnih receptih in seveda so prepričani, da ima tudi Slovenija veliko možnosti, da ob upoštevanju nekaterih enostavnih pravil - zadostne javne naložbe $v$ izobraževanje in raziskave, tesno sodelovanje vseh delov raziskovalne sfere med seboj in z gospodarstvom, ki raziskave podpira s svojim kapitalom, ob tem pa še najširša politična in še širša družbena podporaponovi finsko zgodbo o uspehu.

Takšne stvari je lepo slišati in lepo je tudi verjeti vanje. Navsezadnje, to vemo vsi, imamo s Finsko veliko skupnega. Le polovico manj prebivalcev od njih, jezik, ki ga tako kot finskega skoraj nihče drug v Evropi - in prav nihče $v$ EU - ne razume (a skoraj vsi Finci odlično obvladajo tudi švedščino in angleščino), bogastvo voda in gozdov, pridne delavce ... No, družijo nas tudi manj prijetne stvari, kot je veliko število samomorilcev in težave $z$ alkoholom. A te pač ne sodijo $v$ to razvojno obarvano zgodbo. Vendar bi lahko primerjavo med nami in Finci začeli tudi s čisto drugimi podatki, ki jih skoraj nihče ne pozna.

Ali si tisti, ki se je pravkar vrnil s Finske - zame je bilo to drugo srečanje z njo v zadnjih dveh letih - sploh lahko predstavlja, da je ta država, ki je zdaj tudi uradno slovenski razvojni vzor, šele pred dobrimi 13 leti, $v$ začetku 9o. let, torej sočasno z začetkom naših tranzicijskih razvojnih muk, pospremljenih z zlomi številnih podjetij ter velikim porastom nezaposlenosti, preživljala globoko krizo, ki so jo sprožili podobni tranzicijski vzroki kot pri nas?

Tudi Finska je morala preživeti izgubo dotedanjih vodilnih trgov, $v$ njenem primeru predvsem sovjetskih, poleg tega pa tudi posledice prekomernih investicij v predhodnih letih, ki so načele njen finančni sistem, predvsem pa drastično povečale obrestne mere. Nezaposlenost na Finskem je v tem obdobju poskočila na 20 odstotkov, veliko njenih podjetij je šlo v stečaj, država se je morala spopasti z velikim proračunskim pri- 
manjkljajem, standard prebivalcev se je izrazito znižal. Jasno je bilo, da bodo morali tako država kot vsi prebivalci začasno stisniti pas, ob tem sprejeti učinkovite sanacijske in razvojno spodbujevalne ukrepe ter počakati, da le-ti začnejo delovati.

Se vam zdi ta scenarij znan? Nekako bolj slovenski kot finski - za to državo si vendar večina Slovencev predstavlja, da že vsaj 20 let živi v blaginji, v nekakšnem visokotehnološkem raju. Naj predstavo o podobnosti podkrepim še s presenetljivo ugotovitvijo, do katere naj bi prišli med obiskom na Finskem med srečanjem s finskimi podjetniki naši gospodarstveniki - namreč o tem, da naj bi si bili gospodarstvi obeh držav $v$ osnovni sestavi skoraj na las podobni. Skoraj enaki deleži kmetijske proizvodnje, industrije, storitvenih dejavnosti ...

Vendar je, seveda, današnji finski izvoz nekaj čisto drugega kot naš. Ne le po obsegu, temveč predvsem po tem, da ima v finskem visoka tehnologija neprimerno večji delež kot v našem izvozu. Skratka, njihov izvoz je tudi izkaznica njihovega razvojnega uspeha. Je tisto, od česar lahko Finci danes razmeroma zelo dobro živijo in se na uradnih lestvicah kakovosti življenja uvrščajo v tisto peščico držav na svetu, kjer naj bi bilo najprijetneje živeti. In tu se zdaj lahko vrnemo k tisti krizi iz začetka 9o. let, ko smo si bili na videz tako presenetljivo podobni, $v$ resnici pa neznansko različni.

Kajti Finci so se tedaj namesto za neplodna politična prerekanja o tem, kdo je kriv za gospodarski polom in kdo lahko iz tega potegne večjo politično korist oziroma kdo bo iz gospodarskih ruševin potegnil največjo osebno materialno korist, odločili za čisto drugačno taktiko - dosegli so nacionalni razvojni konsenz in niso inovacijske družbe, oziroma družbe znanja, oblikovali le deklarativno, temveč so zares nadvse uspešno reorganizirali svoje gospodarstvo in domači trg, pritegnili so tuje investitorje, drastično povečali produktivnost in s tem tudi konkurenčnost. Od tod do tretjinskega izvoza visoke tehnologije je bil nato potreben le še korak, dolg kakšnih deset let.

Zato sploh ni res, da so Finci za sedanji uspeh potrebovali dolga desetletja. Ne, še pred 15 leti smo si bili zelo blizu, čeprav so bili oni tedaj že dolgo $v$ kapitalizmu, mi pa smo se komaj izvili iz komunizma. A razvojni nesporazum, ki se je zgodil pri nas, je bil v tem, da tedaj razen redkih entuziastov pri nas nihče $v$ resnici ni verjel, da so inovacije oziroma znanje edini pravi ključ do razvojnega uspeha. Finci so verjeli in zmagali. Ali vsaj zdaj zares verjamemo tudi mi? 


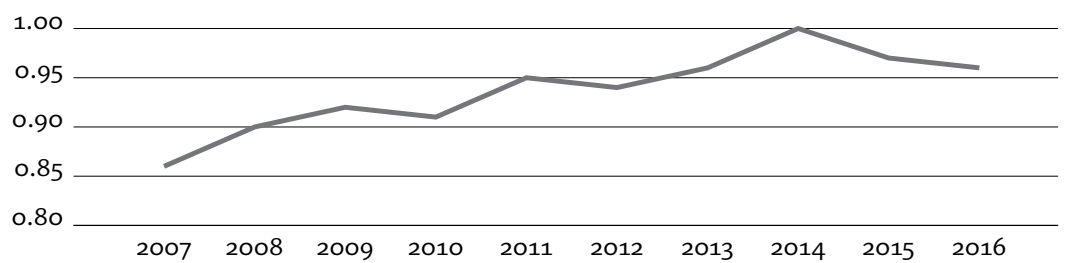

Slika 6.2 Evropski inovacijski indeks (primerjava E U in Slovenije) Po podatkih ARRS (https://www.arrs.gov.si/sl/analize/odlicnost).

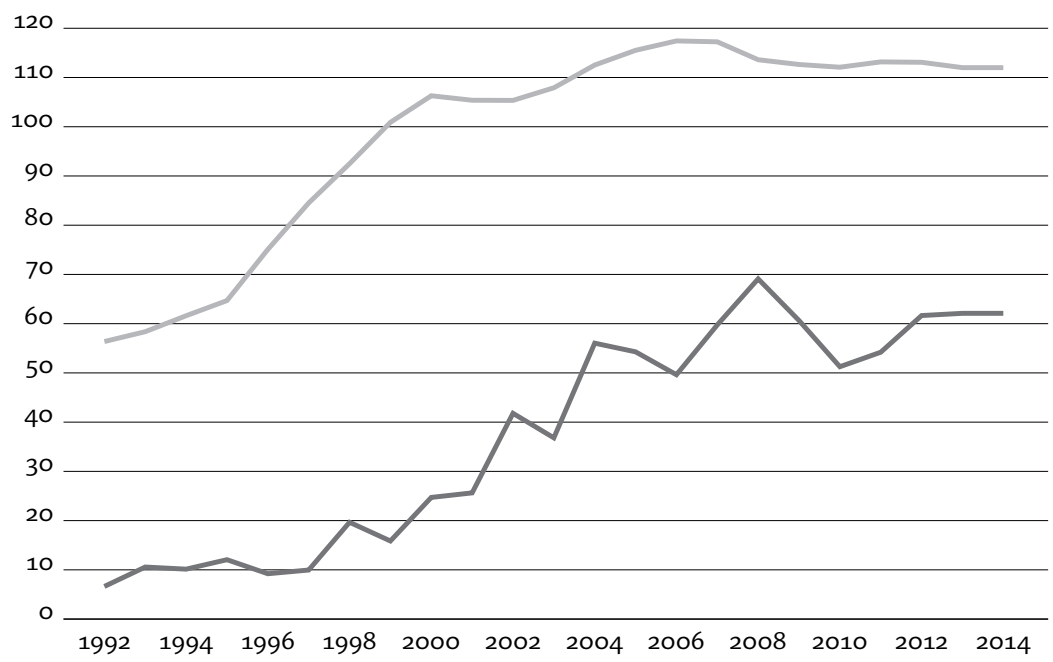

Slika 6.3 Število patentnih prijav (primerjava EU in Slovenije)

Temno - Slovenija, svetlo - EU-28. Po podatkih ARRS (https://www.arrs.gov.si/sl/ analize/odlicnost).

\section{Vloga znanstvene in tehnološke politike}

Od leta 2007 E U letno objavlja Evropski inovacijski indeks (glej https: //ec.europa.eu/growth/industry/innovation/facts-figures/scoreboards _en), ki zajema podatke o celotni inovacijski verigi: o znanosti (kadri, znanstveni rezultati, finančna podpora), aktivnostih podjetij (investicije v R R, mreženje in podjetništvo, intelektualna lastnina) in outputih (inovacijska podjetja, ekonomski učinki). Slika 6.2 ponuja primerjavo Slovenije z evropskim povprečjem od leta 2007 do 2016 . Kot lahko razberemo iz grafa, je na področju inovacij Slovenija v slabem desetletju naredila premik, vendar pa evropskega povprečja nikakor ne more doseči - celo nasprotno, v zadnjih letih se od njega spet oddaljuje.

Pomemben element evropskega inovacijskega indeksa so podatki o mednarodnih patentnih prijavah (slika 6.3). Po osamosvojitvi smo gle- 
de patentnih prijav krepko zaostajali za Evropo, dosegali smo le deset odstotkov evropskega povprečja, potem pa se je število začelo vztrajno dvigovati, vse do leta 2008, ko smo se evropskemu povprečju najbolj približali. Po letu 2008 se je gibanje obrnilo navzdol; v zadnjih letih število patentnih prijav dosega 40 odstotkov evropskega povprečja (po podatkih Eurostata, http://ec.europa.eu/eurostat). Podrobnejši vpogled v podatke pokaže, da približno polovica vseh slovenskih patentnih prijav prihaja iz dveh podjetij z isto dejavnostjo (proizvodnja zdravil), kar je ena od glavnih težav, s katerimi se Slovenija na tem področju srečuje.

Oba indeksa, patentni in inovacijski, podatkov seveda ne črpata le s področij univerz in inštitutov, ki v tem primeru predstavljata le manjši delež celote. Univerze in inštituti v slovenski strukturi prijave patentov predstavljajo le od pet- do desetodstotni delež, ki je primerljiv z razvitimi evropskimi državami, vendar nižji od z D A, Japonske in Južne Koreje (glej http://cordis.europa.eu).

Kako bi lahko primerjali tehnološko-razvojne rezultate in rezultate znanosti? Število slovenskih mednarodnih patentov in kazalci slovenske znanstvene odličnosti so bili glede na evropsko povprečje leta 1991 med seboj primerljivi. Takrat je število slovenskih člankov, zavedenih v bazi wos, dosegalo polovico in njihova citiranost petino evropskega povprečja, število patentov pa desetino. Kazalec, povezan z odličnostjo znanstvenih objav, se je zatem strmo dvigal, kar pa ne velja za kazalec števila patentov, ki je danes približno na polovici evropskega povprečja. Podobne izhodiščne parametre lahko ugotavljamo pri evropskem inovacijskem indeksu. Razkorak med E U in Slovenijo je bil pred desetimi leti podoben tistemu pri citiranosti, vendar smo za razliko od nadpovprečnih rezultatov, ki jih je zatem dosegla slovenska znanstvena odličnost, $v$ okviru evropskega inovacijskega indeksa še vedno pod evropskim povprečjem.

Posvetimo se za hip spodbujanju razvoja znanosti še $\mathrm{z}$ vidika gospodarstva. V Sloveniji je $\mathrm{v}$ gospodarstvu danes zaposlenih 25 odstotkov doktorjev znanosti, kar ni majhen delež, vendar pa je še vedno nižji kot, denimo, v Z D A ali na Danskem, kjer je 35-odstotni. Bolj kot delež so problematični dohodki doktorjev znanosti v gospodarstvu, saj so za razliko od Slovenije v večini držav, še posebej pa v razvitih, višji od dohodkov doktorjev znanosti v akademskem okolju (Auriol idr., 2013; Arsenjuk, 2015).

ARRS je s projektom mladih raziskovalcev res uspešno vzgajala nove doktorje znanosti, ob tem pa država ni poskrbela za socialno kapi- 
co, s katero bi doktorji znanosti postali za gospodarstvo finančno konkurenčni in s katero bi jim omogočili evropsko primerljive pogoje za ustvarjalno delo (višje dohodke v gospodarstvu kot $v$ akademskem okolju). Pri prenosu znanja v gospodarstvo pa se zatika tudi zato, ker sodelovanje med univerzami in gospodarstvom ni sistemsko urejeno. Večino sodelovanj se namreč sklene $\mathrm{z}$ avtorskimi pogodbami, med pogosto neplačanimi pogodbeniki pa je velik delež podiplomskih študentov. Ker je za gospodarstvo to kratkoročno cenejše - čeprav dolgoročno manj učinkovito -, se tam raje odločajo za tako obliko sodelovanja, kot da bi doktorje znanosti po opravljenem študijskem usposabljanju redno zaposlili.

Prvi poskusi spodbujanja razvoja, ki jih je država za gospodarske subjekte začela uvajati po tekmovalnih principih, so bili razvojni projekti. Leta 1995 je dal minister Bohinc v sodelovanju s Petrom Stanovnikom z Inštituta za ekonomska raziskovanja pobudo za raziskavo o ekonomskih učinkih razvojnih projektov, ki jih je sofinanciralo ministrstvo, zadolženo za tehnologijo. Načrtovali so, da bi z dobrimi rezultati raziskave utrdili vlogo razvojnih projektov in zanje morda namenili dodatna sredstva. Čeprav je študija izvajanje razvojnih projektov spremljala razmeroma kratek čas, se je na vzorcu okoli stotih projektov pokazalo, da se je že $z$ rezultati zgolj desetine projektov, ki so zaživeli v praksi, pokril finančni vložek države za vseh sto projektov. Kljub temu pa so bili v eni od kasnejših reorganizacij ministrstva (leta 2000), ko je tehnologija prešla v pristojnost ministrstva za gospodarstvo, razvojni projekti opuščeni.

Leta 2004 je bila hkrati z ARRS ustanovljena Javna agencija za tehnološki razvoj Republike Slovenije (T I A), ki je prevzela financiranje projektov, ki so prej potekali na ministrstvu, zadolženem za tehnologijo. Agencijo TI A so zasnovali po modelu finske ustanove Tekes, vendar T IA pomena Tekesa, ki na Finskem razpolaga $\mathrm{z}$ več sredstvi kot raziskovalna agencija, nikoli ni dosegla.

T IA je za svoje instrumente financiranja prejela komaj desetino zneska, s kakršnim je razpolagala A R RS, poleg tega pa delo obeh agencij ni bilo usklajeno. Zgovorno je tudi dejstvo, da je bilo za tehnološko agencijo sprva zadolženo isto ministrstvo kot za znanost, od leta 2008 pa je to postalo ministrstvo, zadolženo za gospodarstvo, kjer je agencija izgubila samostojnost in tudi večino finančnih virov za svoje delo. TIA, ki je bila leta 2013 skupaj s še dvema ustanovama združena v agencijo Spirit, ni več pomemben dejavnik spodbujanja tehnološkega razvoja; veči- 
na njenih dejavnosti je prešla v neposredno pristojnost gospodarskega ministrstva. Višina sredstev za tehnološki razvoj je po letu 2008 kljub temu močno narasla, zaradi česar se je finančni obseg povezav med znanostjo in gospodarstvom dvignil nad evropsko povprečje. Poleg tega so se povečala tudi evropska sredstva in s tem vrednost, ki jo je Slovenija iz evropskih sredstev počrpala, med drugim na primer za financiranje t.i. kompetenčnih centrov, ki so poskušali povezati gospodarstvo ter univerze in inštitute.

Slovenija je pred krizo, leta 2009, pripravila strateški dokument »Resolucija o raziskovalni in inovacijski strategiji Slovenije 2011-2020 « (2011) z ambicioznimi načrti za vlaganja $\mathrm{V} R \mathrm{R}$, žal pa je ostal le mrtva črka na papirju.

\section{Lepa nevesta ali dota?}

Delo, 10. oktober 1991

Zakon o raziskovalni dejavnosti je bil v slovenski skupščini, če ga primerjamo z večino drugih novih zakonov, sprejet nenavadno gladko. To naj bi pomenilo, da je večina v raziskovalni sferi z zakonom zadovoljna, toliko bolj, ker so predstavniki resornega ministrstva organizirali cel niz posvetov na to temo in pri tem pokazali precej dovzetnosti za predloge popravkov predlaganih zakonskih določil. Seveda ne vseh, toda delno neuklonljivost vlade izvajalci navsezadnje pričakujejo in se razen tega sami med seboj še veliko bolj razhajajo, kot se v povprečju vsebina zakona od njihovih pričakovanj.

Zaradi teh dejstev nas lahko preseneti kritičnost nedavne razprave o uresničevanju tega zakona, organizirane v okviru pristojnega skupščinskega odbora. Toda zdi se, da so jo vsaj delno sprožili dogodki, ki jih v času omenjenih razprav pred sprejemom zakona še ni bilo ali vsaj niso bili tako vidni. Dotok iz republiškega proračuna je vse bolj negotov, s tem pa tudi načrti, da naj prihodnje leto raziskovalno področje dobi za realno petino več denarja. Tistim, ki zanesljivo računajo na vladno podporo, se torej zdi, da bi moral zakon veliko bolj določno opredeliti obveznost do njih - jim zagotoviti plačilo čim večjega dela stroškov in jim hkrati zagotoviti proste roke pri morebitnemu kadrovskemu razbremenjevanju.

Na drugi strani so še veliko številnejši bodoči raziskovalni zavodi in podjetja, ki ne morejo več upati na prednosti statusa dotiranih javnih 
zavodov. Ti v zakonu pogrešajo predvsem zagotovljeno "pravično" razdelitev državnih projektov, motijo jih tudi normativi in standardi, ki po njihovem zapostavljajo prakso. Vse klavrnejše razmere v gospodarstvu jih silijo $k$ državnim jaslim - to, da tam zanje ne bo dovolj prostora, pa pripisujejo tudi pomanjkljivostim tega zakona in si seveda želijo razen popravkov njegov odlog.

Toda najzanimivejša so vendar tista ozadja dvomov o zakonu, ki jih je sprožilo spoznanje, da »lepota «tistih, ki so ustvarili zakon (torej kadrovska sestava ministrstva za znanost in tehnologijo), nikakor ni trajna, precej dlje pa utegne trajati »kilava dota " precejšnjih pooblastil, ki jih je z zakonom dobilo to ministrstvo. Zato je najsporneje $v$ zakonu prav tisto, kar je v določenih razmerah lahko najučinkovitejše - da je namreč pisan na kožo danih razmer in ljudi v njih. Sicer pa dileme, ali naj bo nevesta raje bogata kot lepa, tako ali tako še nihče ni zadovoljivo rešil.

\section{Umestitev raziskav in razvoja v širši družbeni kontekst}

V prejšnjem poglavju smo ugotavljali, da inovacijski sistem v Sloveniji ne deluje optimalno. Vendar je vsekakor spodbudno, da je delež vlaganj $\mathrm{v}$ raziskave in razvoj v poslovnem sektorju višji od evropskega povprečja, in to tako glede vlaganj samega gospodarstva kot državne podpore $z$ davčnimi olajšavami ali subvencijami. Po drugi stani pa ne moremo zanemariti dejstva, da smo povprečje E U po višini vlaganj v R R prehiteli šele pred slabim desetletjem, malo pred finančno krizo. Pravi učinki večjih vlaganj v raziskave in razvoj se namreč pokažejo šele na daljši rok in $\mathrm{v}$ razmeroma urejenem gospodarskem okolju, ki pa ga sanacija posledic gospodarske krize vsekakor ni nudila.

Pomemben razlog, da gospodarstvo v razvoj ni vlagalo dovolj sredstev, so bile druge prioritete - Slovenija se je v 25 letih svoje samostojnosti namreč veliko in neučinkovito ukvarjala s privatizacijo gospodarstva. Ko je Slovenijo leta 2011 zajela finančna kriza, je bila zaradi tega gospodarsko precej šibka, zato ni presenetljivo, da jo je prizadela bolj kot druge države EU.

Argument, da razlog za slovenske gospodarske probleme ni v prvi vrsti povezan s slovensko tehnološko (ne)razvitostjo gospodarstva in $z$ znanstveno infrastrukturo, najdemo v analizi podatkov iz Globalnega indeksa konkurenčnosti (World Economic Forum, 2015), pridobljenih s podrobnimi anketami in $\mathrm{z}$ naborom statističnih kazalcev konkurenčnosti v 144 državah (Stanovnik, Uršič, in Rangu, 2017). Konkurenčnost 


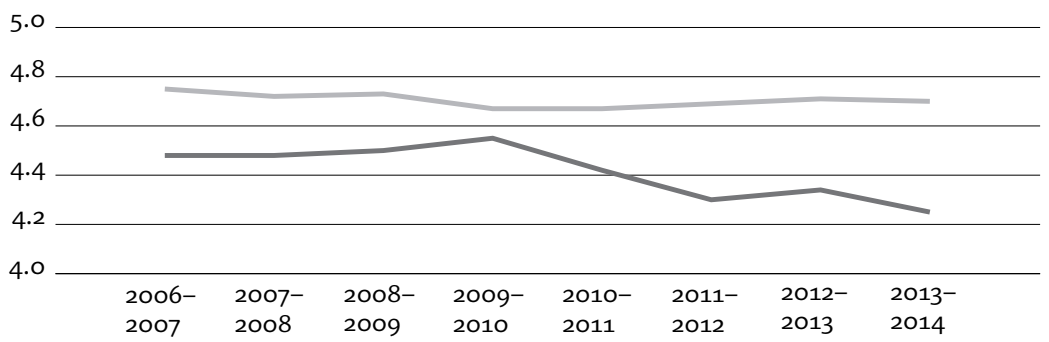

Slika 6.4 Globalni indeks konkurenčnosti (primerjava E U-28 in Slovenije) Temno - Slovenija, svetlo - E U-28. Povzeto po World Economic Forum (2015).

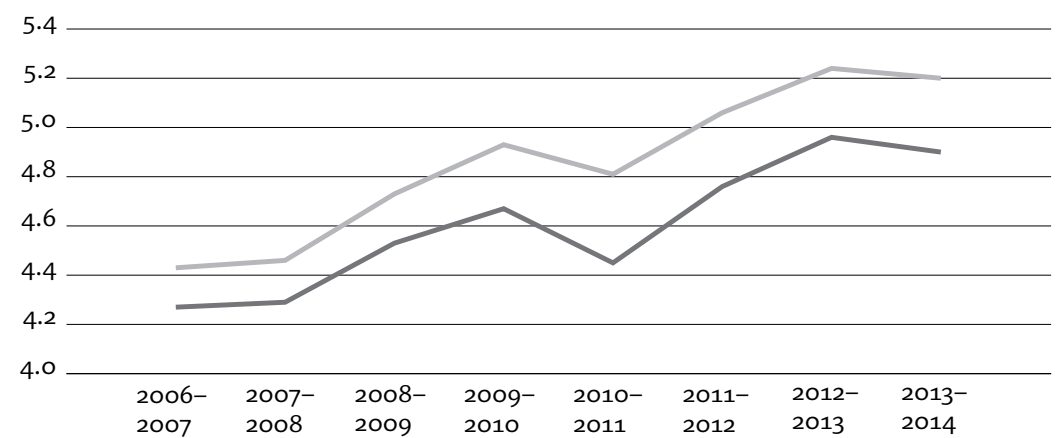

Slika 6.5 Globalni indeks konkurenčnosti - primerjava tehnološke usposobljenosti V E U-28 in Sloveniji

Temno - Slovenija, svetlo - E U-28. Povzeto po World Economic Forum (2015).

gospodarstva se je z nastopom krize leta 2011 zaradi vrste nakopičenih strukturnih razlogov v Sloveniji krepko znižala, veliko bolj kot v celotni E U (slika 6.4).

Podoben graf bi dobili, če bi si ogledali posamezne sestavne dele tega indeksa, recimo podatke o delovanju finančnega trga ali podatke o učinkovitosti trga dela. Vsebinski podatki tega indeksa pa po drugi strani pokažejo, da do znižanja inovativnosti in tehnološke usposobljenosti slovenskega gospodarstva ni prišlo (slika 6.5).

Zanimivo je, da rezultati javnomnenjske ankete prebivalcev Slovenije o tem, na kaj so najbolj ponosni - opravijo jo približno na vsakih deset let $(1994,2003,2013)$-, pokažejo podobno sliko kot globalni indeks konkurenčnosti: znanstveni in tehnološki dosežki so skoraj najvišje na seznamu, takoj za športnimi dosežki. V preglednici 6.1 na naslednji strani, ki kaže primerjave še z drugimi dejavnostmi, vidimo, da so bili znanstveni in tehnološki dosežki edini, ki jim je v samostojni Sloveniji ugled stalno občutno rasel. 
Preglednica 6.1 "Na kaj smo v Sloveniji najbolj ponosni?«

\begin{tabular}{lrrr}
\hline Odgovor & 1994 & 2003 & 2013 \\
\hline Na dosežke njenih športnikov & 87,6 & 83,5 & 93,2 \\
Na njene znanstvene in tehnološke dosežke & 53,1 & 59,7 & 70,7 \\
Na slovensko zgodovino & 70,3 & 77,6 & 70,2 \\
Na njene dosežke v umetnosti in literaturi & 66,6 & 66,9 & 69,1 \\
Na Slovensko vojsko & 53,0 & 44,3 & 48,5 \\
Na slovenske gospodarske dosežke & 31,2 & 43,9 & 28,3 \\
Na njen sistem socialne varnosti & 26,9 & 32,9 & 27,9 \\
Na pravično in enakopr. obravnavo vseh skupin v družbi & 35,2 & 34,4 & 22,1 \\
Na politični vpliv Slovenije v svetu & 24,9 & 32,0 & 8,2 \\
Na način delovanja demokracije v Sloveniji & 18,8 & 26,3 & 7,1 \\
\hline
\end{tabular}

OP OMBE Anketni odgovori, povzeti po Toš (2017). Znanost in tehnologija je edino področje, ki se mu v Sloveniji ugled ves čas opazno veča.

Iz predstavljenih podatkov bi lahko izpeljali vsaj dva sklepa. Prvič, vlaganja $\mathrm{v}$ raziskave in razvoj imajo pomemben vpliv na blagostanje družbe - in to velja tudi za Slovenijo. Drugič, za razvoj države so zelo pomembni tudi drugi elementi, celo toliko, da lahko učinkovite ukrepe na področju raziskav in razvoja povsem izničijo. Javnomnenjske raziskave kažejo, da slovenska javnost to razume.

\section{Cena zapostavljanja družbenih ved}

Vest naravoslovja, tehnike in razvoja - podcenjevanje humanistike in družboslovja je evropski problem

Delo, 19. april 2012

»Gospodarska in družbena kriza močno prizadeva družboslovje in humanistiko in na mnogo področjih že onemogoča njun obstoj, nadaljnji razvoj disciplin ter interdisciplinarno in mednarodno povezovanje.« To je eden od sklepov posveta o nujnosti družboslovja in humanistike $v$ sodobni družbi.

Na posvetu in okrogli mizi, ki sta prejšnjo sredo pod pokroviteljstvom nacionalne komisije za Unesco potekala v atriju ZRC SAZU, so družboslovci in humanisti različnih profilov nujnost ohranitve družboslovja in humanistike dokazovali predvsem z aktualnimi razmerami $v$ naši državi, kjer se po njihovem mnenju večina oblastnikov pomena teh ved premalo zaveda in njihove strokovne ugotovitve in priporočila pri odločitvah premalo ali pa sploh ne upošteva. Še več: v času krize, tako eko- 
nomske kot politične, se zdita prav družboslovje in humanistika vsakokratni oblasti najmanj potrebna in zato najlažje pogrešljiva. To naj bi kazala tudi lani sprejeta raziskovalna in inovacijska strategija, ki je po oceni direktorjev Pedagoškega inštituta, Urbanističnega inštituta, ZRC SAZU, Inštituta za narodnostna vprašanja, Inštituta za novejšo zgodovino in Mirovnega inštituta že v izhodišču izključila družboslovje in humanistiko - pri nas sta že doslej prejemala manj kot četrtino javnih raziskovalnih sredstev -, ker ta svojih ugotovitev in rezultatov ne moreta neposredno prenašati v gospodarstvo.

Raziskovalcem s teh področij se je zato zdelo potrebno, da dokažejo, da so njihove vede prav tako potrebne kot naravoslovne in tehniške ter da njihovi raziskovalni izsledki niso nič manj znanstveni in uporabni. Že na vabilu na posvet so zapisali, da brez družboslovja in humanistike tudi gospodarstvo ne more učinkovito delovati. Toda sodeč po udeležbi na posvetu so to dokazovali predvsem samim sebi, saj se na vabilo, denimo, ni odzval noben vladni predstavnik (so ga pa videli, kot boste brali v nadaljevanju).

Prof. dr. Rudi Rizman z ljubljanske filozofske fakultete je opozoril na pomen družbenega in političnega zavedanja, da si brez družboslovja in humanistike ni mogoče predstavljati demokracije. Družboslovna in humanistična vednost zajema modrost, potrebno pri iskanju alternative in izhoda iz krize. V naraščajoči kompleksnosti in globalni prepletenosti, $v$ kateri so se znašle današnje družbe, lahko, pravi Rizman, družboslovje in humanistika prispevata $k$ ustvarjanju javnega dobra, ki je pogoj za ohranjanje ter nadaljnji razvoj demokratične družbe.

\section{Slovenija je iz strpne postala represivna država}

Dr. Dragan Petrovec z Inštituta za kriminologijo na ljubljanski pravni fakulteti je nazorno prikazal, kako se Slovenija zaradi neupoštevanja izsledkov družboslovno-humanističnih ved, še zlasti kriminalističnih in pravnih znanosti, iz ene najbolj strpnih evropskih držav spreminja $v$ eno najrepresivnejšo. Poudaril je, da se je brez strokovnih podlag odločila za izredno zaostritev kaznovalne politike, katere neučinkovitost se najbolje kaže s prepolnimi zapori. Kot je dejal Petrovec, se je Slovenija $z$ uvedbo dosmrtne zaporne kazni uvrstila $v$ skupino držav z najbolj represivno kaznovalno politiko, kot neprimerno drastično kazen je omenil tudi uklonilni zapor.

Dr. Srečo Dragoš z ljubljanske fakultete za socialno delo je argumentiral tezo, da je Slovenija v zadnjih sto letih že štirikrat izgubila prilo- 
žnost, da postane socialna država. Prvič med svetovnima vojnama, ko se je v razpravah o socialni državi omenjala celo ideja samoupravljanja, drugič po drugi svetovni vojni, ko bi država lahko razvila avtonomno socialno politiko, namesto da jo je razdrobila $v$ druge politike, podrejene partijski, tretjič pa ob vstopu Slovenije v Evropsko unijo, ko bi lahko prevzeli koncept evropske socialne politike. Četrto priložnost za socialno državo izgubljamo, pravi Dragoš, prav zdaj, ob iskanju izhoda iz krize, ker postavljamo zgrešene cilje pri premagovanju revščine.

Prof. dr. Mitja Žagar z Inštituta za narodnostna vprašanja je dejal, da sta družboslovje in humanistika pomembna za oblikovanje kakovostnih razvojnih strategij in še zlasti za pripravo celovitih dolgoročnih strategij upravljanja različnosti v pluralnih družbah, kot je tudi naša. Meni, da lahko prispevata $k$ družbenemu razvoju in zlasti $k$ stabilnosti in občutku vključenosti in varnosti ljudi v nekem okolju. Zato se mu zdi pomembno, da se nenehno preverjajo merila ocenjevanja uspešnosti raziskovalcev ter tudi družboslovja in humanistike.

Nekdanji dekan ljubljanske filozofske fakultete prof. dr. Valentin Bucik je družboslovje in humanistiko označil za vest naravoslovja in tehnike ter razvoja. Izrazita zapostavljenost, zanemarjenost in podcenjevalen odnos do družboslovja in humanistike v zadnjem času - včasih so skriti za krinko izgovarjanja na krizo, v kateri je treba najprej poskrbeti za gospodarski in ekonomski napredek, druga področja pa bodo prišla na vrsto kasneje - so po njegovem evropski, ne zgolj slovenski problem. Poudaril je še, da so s predstavniki uglednih evropskih univerz oziroma njihovih humanističnih in družboslovnih fakultet glede tega enotnega mnenja, prav tako vsi sodijo, da je takšen pogled zgrešen in poguben za človeško civilizacijo.

\section{Bo ukinjanje »odvečne « filozofije prišlo tudi k nam?}

Kot smo slišali na okrogli mizi, slovensko družboslovje in humanistika $v$ marsičem delita usodo teh ved $v$ sodobnem svetu. Tako tudi na uglednih tujih univerzah, ki se pretežno financirajo iz javnih sredstev, zapirajo oddelke za filozofijo, vzgojo in še nekatere druge družboslovne in humanistične vede. To se dogaja celo tam, kjer je za tovrstne študije dovolj zanimanja. Razlog je menda zgolj to, da te študije oblasti, ki dajejo denar, slabše točkujejo, od točk pa je odvisno financiranje univerz. Nižja ocena je posledica stališč, da so to, vsaj z zornega kota družbenih interesov, manj pomembni študiji. Zato se jim univerze, ki želijo dobiti čim več denarja, raje odrečejo. 
Posveta na ZRC SAZU naj bi se udeležil tudi rektor ljubljanske univerze prof. dr. Stanislav Pejovnik, sicer doktor kemijskih znanosti, ki prav tako vodi nacionalno komisijo za Unesco. Rektor ni prišel - bil je nujno zadržan -, je pa zato posebej za našo prilogo predstavil svoje stališče o pomenu družboslovnih in humanističnih ved: »Današnji svet pogosto definiramo kot globalno vas. Dejansko pa živimo v svetu, polnem tako velikih nasprotij, kot jih na našem planetu še ni bilo. Na enem koncu se bogati borijo z debelostjo, na drugem vsakih dvajset sekund zaradi lakote umre otrok. Na enem koncu proizvajajo novo in novo orožje, ga za velike denarje prodajajo na drugi konec, kjer se neusmiljeno pobijajo, medtem ko modri varnostni svet tedne in mesece razpravlja o tem, kaj bi morali narediti. Vsakemu polpismenemu človeku pa je jasno, da se brez orožja ne da pobijati. In še in še bi lahko našteval.

Zakaj me mučijo takšna vprašanja? Domnevam, da je eden od vzrokov dejstvo, da so multinacionalke in centri finančnega kapitala pomembno prispevali $k$ temu. Zakaj? V takšnih globalnih sistemih, ki večinoma poslujejo zunaj vseh znanih kontrolnih mehanizmov demokratičnega sveta (volitve, odgovornost družbeni skupnosti, ne le lastnikom ...), je edino gibalo razvoja profit. To pa pomeni popolno konkurenco. Zaradi tega so zainteresirani le za financiranje projektov, ki dajo rezultat takoj.

To seveda zahteva izjemno specializacijo in vodi $v$ fragmentiranost ter nazadnje pripelje do neenakomernega razvoja znanosti in tehnike na eni strani ter humanističnih raziskav na drugi. Zadnje so strahovito podfinancirane, saj ne samo da večinoma ne dajejo profita takoj, ampak pogosto celo opozarjajo, da svet ne sme iti v smer, ki ustreza centrom finančnega kapitala. Končna posledica je pomanjkanje celovitega, holističnega pristopa $k$ reševanju nenavadnosti, ki sem jih namenoma $v$ rahlo pretirani obliki prikazal na začetku. Zato sem, čeprav trd naravoslovec, vedno bolj prepričan, da je edina možna pot tista, ki omogoča celovit in sočasen razvoj vseh znanosti. Zato moram tako delovati tudi kot rektor univerze (universita $=$ celota)."

Omenimo za konec še to, da je dr. Borut Rončević, soustanovitelj fakultete za uporabne družbene študije, sedanji direktor Direktorata za visoko šolstvo in znanost na Ministrstvu za izobraževanje, znanost, kulturo in šport - za ti področji tam ni državnega sekretarja - na svojem blogu komentiral vabilo na omenjeni posvet. Napisal je, da je dogodek najprej razumel kot "razmeroma nekreativno kruhoborsko manifestacijo«, nato pa si je vabilo vendar zaslužilo njegovo pozornost, 
Umestitev raziskav in razvoja v širši družbeni kontekst $\mid 6$

namreč, da je trditve v njem izredno grobo skritiziral. „Tisti, ki je sposoben zagovarjati tak ocvirk, "piše Rončevič, »res ne zasluži posebnega spoštovanja." 



\section{Univerze/inštituti}

Znanstveno raziskovanje pri nas in $\mathrm{v}$ svetu večinoma poteka na univerzah in raziskovalnih inštitutih. Kakšna je med njimi razlika?

Tipični univerzitetni profesor večino svojega delovnega časa porabi za pedagoško delo, del pa ga nameni raziskavam, ki jih financirajo nacionalne agencije za temeljno znanost. Nekateri profesorji sodelujejo še pri raziskovanjih, ki so podprta $z$ mednarodnimi finančnimi viri (recimo z evropskimi sredstvi), pri razvojnih projektih za gospodarstvo (ki jih lahko sofinancirajo tudi tehnološke agencije), pri različnih strokovnih projektih in promociji raziskovalnega dela.

V svetu prevladujeta dva tipa raziskovalnih inštitutov: tisti, ki se ukvarjajo pretežno s temeljnimi raziskavami (recimo Max-Planckovi inštituti $\mathrm{v}$ Nemčiji), in tisti, ki se ukvarjajo pretežno $\mathrm{z}$ aplikativnimi raziskavami (recimo Fraunhoferjevi inštituti v Nemčiji). Tipični raziskovalec na raziskovalnem inštitutu za temeljno znanost večino svojega delovnega časa porabi za raziskave, ki jih financirajo nacionalne agencije za temeljno znanost. Deloma sodeluje tudi pri pedagoškem procesu na univerzah, pri raziskovanjih, ki so podprta $z$ mednarodnimi finančnimi viri (recimo $z$ evropskimi sredstvi), razvojnih projektih za gospodarstvo (ki jih lahko sofinancirajo tudi tehnološke agencije) ter pri različnih strokovnih projektih in promociji raziskovalnega dela. Tipični raziskovalec na raziskovalnem inštitutu za aplikativne raziskave večino svojega delovnega časa porabi za razvojne projekte za gospodarstvo (ki jih lahko sofinancirajo tudi tehnološke agencije). Deloma pa sodeluje tudi pri raziskovanjih, ki jih financirajo nacionalne agencije za temeljno znanost, pri raziskovanjih, ki so podprta $z$ mednarodnimi finančnimi viri (recimo $z$ evropskimi sredstvi), ter pri različnih strokovnih projektih in promociji raziskovalnega dela.

Kaj torej loči profesorja na univerzi in raziskovalca na inštitutu? Največja razlika med njima je $v$ tem, da je profesor pretežno vpet $v$ pedagoški proces, njegova osrednja dejavnost je povezana s študenti, raziskovalec na inštitutu pa je bolj osredotočen na raziskovanje, ki je glede na 
usmeritev inštituta lahko temeljnega ali aplikativno-tehnološkega značaja. Je za državo bolje, da se več raziskav opravi na univerzah ali na inštitutih?

Za odgovor na to vprašanje se moramo najprej vprašati, kaj je namen znanosti. Graham Lawton znanost opredeljuje kot metodo sistematičnega postavljanja vprašanj in iskanja odgovorov nanje (»The Big Questions«, 2014). Na ta način se poraja novo in novo znanje, s tem se gradi svetovna zakladnica znanja, iz katere lahko črpajo gospodarstvo pri iskanju novih tehnoloških rešitev, kultura za civiliziranje družbe, družba pa pri prizadevanjih za splošno dobro.

A pri tem smo nekaj spregledali. Svetovna zakladnica znanja namreč predpostavlja zgolj javno dostopne rezultate znanstvenega raziskovanja (članke, študije, razprave, knjige), ne pa tudi drugih poti, po katerih se znanstvena dognanja širijo. Veliko vlogo - še posebej za male države - pri širjenju znanja igrajo med drugim osebni stiki.

Med stiki sta najpomembnejša stik med razvojnikom v podjetju ter raziskovalcem na inštitutu ali univerzi in stik med profesorji in študenti. Prvi stik se vzpostavlja, kadar univerza ali inštitut gospodarstvu lahko ponudita primerna znanja. Pri tem ni pomembno, katera od teh ustanov postane partner gospodarstva - v Sloveniji ima gospodarstvo sicer nekaj več pogodb z univerzami kot $\mathrm{z}$ inštituti -, pomembno je predvsem področje raziskav.

Ozrimo se še $k$ stikom med profesorji in študenti. V študijskem procesu je ključen prenos tistega znanja, ki izhaja iz temeljnih raziskav. Pri primerjavi dveh profesorjev, ki sta približno enako dobra predavatelja, ima tisti profesor, ki je obenem tudi dober raziskovalec, pri pedagoškem delu bistveno prednost. Poučevanje na univerzi, še posebno na stopnji doktorskega študija, je glede na način prenašanja znanja namreč korak dlje od srednješolskega poučevanja. Pomembno postane ne le ustaljeno, že splošno sprejeto znanje, kakršnega narekuje srednješolski učni program, temveč tudi živo znanje, znanje, ki je še v razvoju. Tako znanje pa lahko prepričljivo podajajo samo tisti profesorji, ki pri razvijanju novih znanj tudi sami sodelujejo, ki so torej tudi raziskovalci. Univerza zato lahko le s takšnimi kadri oziroma z raziskovalnimi možnostmi vzdržuje kakovostno raven študija.

Vrnimo se zdaj k vprašanju, ali je za državo pomembnejše raziskovanje na univerzah ali na inštitutih (Matekovič, 2017). Odgovor se težko nagne na eno ali drugo stran, saj je pomembno tako raziskovanje na univerzah kot na inštitutih, enako pomembni pa sta tudi temeljno in 


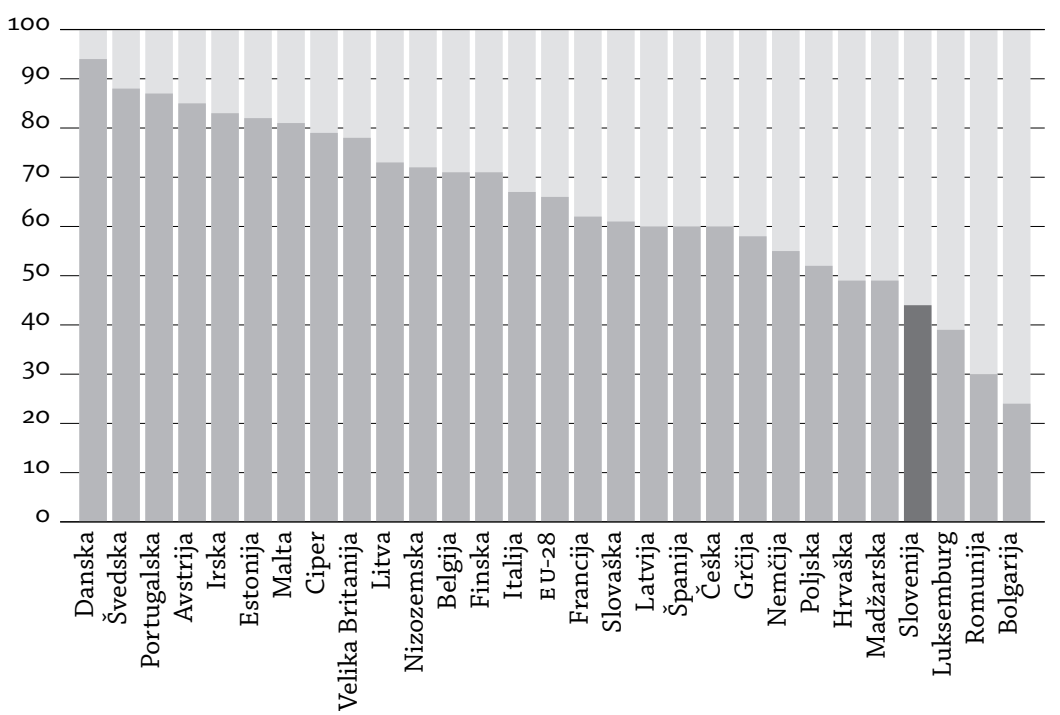

Slika 7.1 Razmerje med izdatki za R R v visokošolskem (univerze - temno) in vladnem (inštituti - svetlo) sektorju v evropskih državah in E U-28 za leto 2013

Po podatkih Eurostata (http://ec.europa.eu/eurostat).

aplikativno raziskovanje. Vsekakor pa je za državo izjemno koristno, da temeljno raziskovanje $\mathrm{v}$ čim večjem obsegu poteka na univerzah, saj ga študentje s pridom uporabijo tudi na delovnih mestih po študiju. A to seveda ne velja brezpogojno - velikih znanstvenih projektov (kot je, recimo, pospeševalnik v Cernu) brez znanstvenikov, ki se povsem posvetijo raziskovanju, ni mogoče izpeljati, pogosto pa so raziskovalci brez drugih obveznosti pomembni tudi pri manjših projektih.

Poglejmo si, na katero stran se države pri dvojici univerze/inštituti nagibajo po statističnih podatkih glede na sredstva, namenjena raziskavam (slika 7.1).

Iz slike lahko razberemo, da se raziskovanje v E U večinoma odvija na univerzah (2/3), kar podpira mojo prejšnjo misel. $Z$ učinkovitejšim prenosom znanja s profesorjev na študente, za katerega je potrebno, kot smo ugotavljali, tudi raziskovalno delo, se oblikuje tudi uspešnejši inovacijski sistem, zaradi česar v E U prevladuje raziskovanje na univerzah.

Slovenijo najdemo v zadnjem delu grafikona, družbo nam večinoma delajo bivše vzhodnoevropske države - Romunija, Bolgarija, Poljska. Največji raziskovalni inštituti v Sloveniji so s področja naravoslovja in humanistike: IJ s (fizika, kemija, deloma elektrotehnika), Kemijski in- 
štitut (kemija), ZRC SAZU (humanistika), Nacionalni inštitut za biologijo. $\mathrm{V}$ to skupino javnih ustanov, $\mathrm{s}$ katerimi gospodarstvo že zaradi značilnosti področij sodeluje $\mathrm{v}$ razmeroma omejenem obsegu, spadajo še manjši inštituti, kot sta Inštitut za narodnostna vprašanja in Inštitut za novejšo zgodovino. $\mathrm{Na}$ omenjenih inštitutih so razvili visoko raven znanosti in nekateri oddelki odlično sodelujejo tudi z gospodarstvom. ZRC SAZU se na primer ukvarja s pomembnimi temeljnimi humanističnimi raziskovanji, objavlja temeljna monografska dela, sijajno skrbi za razvoj slovenskih znanstvenih zbirk. $Z$ gospodarstvom in ministrstvi, ki niso neposredno zadolžena za znanost, intenzivneje sodelujejo predvsem znanstvene ustanove s področij tehnike, biotehnike in družboslovja. Inštituti na teh področjih so manjše ustanove, ki skupno prejmejo okoli 15 odstotkov vseh raziskovalnih sredstev, namenjenih inštitutom (Geološki zavod Slovenije, Gozdarski inštitut Slovenije, Inštitut za ekonomska raziskovanja, Inštitut za kovinske materiale in tehnologije, Kmetijski inštitut Slovenije, Pedagoški inštitut, Urbanistični inštitut Republike Slovenije, Zavod za gradbeništvo Slovenije).

Problem razmerja med raziskovalnimi potenciali na univerzah in inštitutih oziroma deleža sredstev, ki je za raziskovanja na univerzah manjši kot na inštitutih, ni samo v višini sredstev, pač pa tudi v tem, da se slovenski raziskovalni inštituti pretežno ukvarjajo s temeljnimi raziskavami in premalo $z$ aplikativnimi. Slika 7.1 na prejšnji strani kaže, da ima med uspešnimi državami E U največji delež inštitutskih raziskovanj Nemčija, in sicer 45 odstotkov, kar je 10 odstotkov manj kot Slovenija. Vendar je velik delež nemškega inštitutskega raziskovanja aplikativno tehnološko usmerjen (Fraunhoferjevi inštituti v celoti, Helmholtzovi in Leibnizovi inštituti pa deloma), pretežno $v$ temeljno raziskovanje pa so usmerjeni denimo Max-Planckovi inštituti. Ob tem je zaradi velikosti države za povezave med znanostjo in tehnologijo v Nemčiji veliko več možnosti kot pri nas.

Razlog, da imajo bivše vzhodnoevropske države približno enako razmerje med inštitutsko in univerzitetno znanostjo, leži v dediščini njihovega inovacijskega sistema, verigah raziskovalnih inštitutov, ki so bili zgrajeni po drugi svetovni vojni in jih praviloma centralno upravljajo akademije znanosti in umetnosti (linearni model). Koncept seveda izhaja iz prizadevanj Sovjetske zveze, da bi čim hitreje nadoknadili tehnološki zaostanek za zahodom, enega od načinov, kako to doseči, pa so videli v intenzivni znanstveni dejavnosti raziskovalnih inštitutov. Vendar je tak inovacijski sistem onemogočal interdisciplinarnost in med njego- 


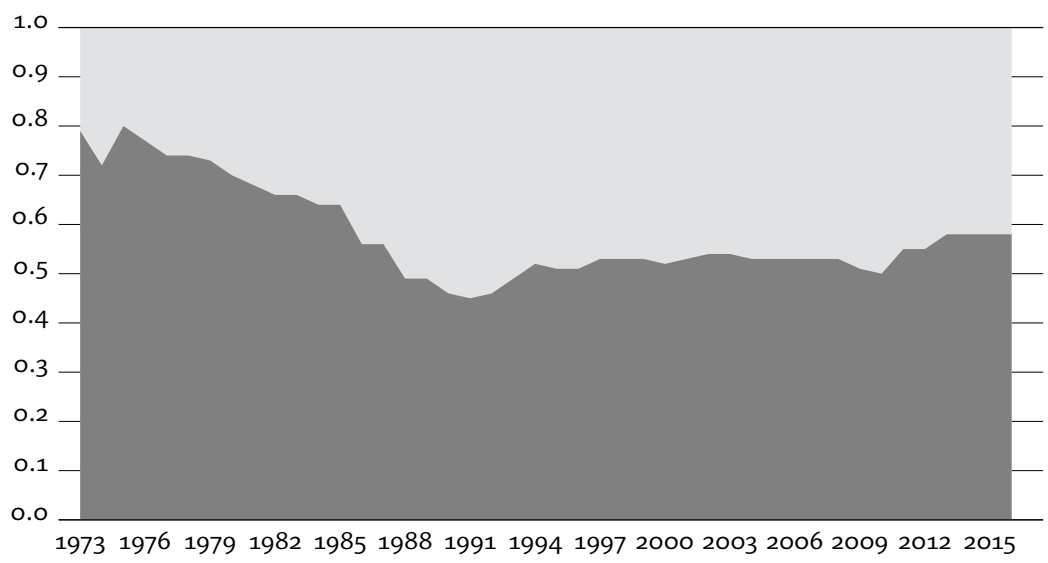

Slika 7.2 Delež financiranja za raziskovanje, namenjen univerzam in raziskovalnim inštitutom

Svetlo - univerze, temno - raziskovalni inštituti. Povzeto po Novak in Demšar (2012).

vimi osnovnimi tremi stebri - univerze, inštituti in gospodarstvo - ni bilo tesnejših medsebojnih povezav. Do tehnoloških premikov je v gospodarstvu zato prihajalo brez sodelovanja $\mathrm{z}$ znanstvenimi ustanovami ali pa so znanstvene dosežke $v$ gospodarstvo implementirali šele potem, ko so jih univerze ali inštituti pripeljali do primerne tehnološke faze. $\mathrm{Za}$ razliko od sovjetskih inštitutov so slovenski inštituti že kmalu po drugi svetovni vojni postali avtonomni. Slabosti sovjetskega modela se je dobro zavedal že prvi direktor IJs Anton Peterlin, ki se je pri zasnovi delovanja inštituta zgledoval pri uspešnih ameriških organizacijskih modelih.

Podatki o razmerju med financiranjem slovenskih univerz in financiranjem slovenskih inštitutov kažejo, da se je pred osamosvojitvijo Slovenije delež sredstev za univerze glede na inštitute nekoliko povečeval, potem pa se je razmerje približno ustalilo (slika 7.2).

Ureditev raziskovanja na univerzah in inštitutih ima tudi neposreden vpliv na kariere raziskovalcev. Prehodi z ene na drugo stran so pri nas skoraj nemogoči. Na univerzah predavajo le redki raziskovalci z inštitutov, res pa najvidnejši med njimi. Inštituti bolj kot univerze skrbijo za kakovostno raziskovalno opremo, zaradi česar imajo boljše raziskovalne pogoje, kar je še posebej pomembno pri raziskavah s področja naravoslovja. Univerze in inštituti so tako obveljali za dva med seboj slabo povezana sistema, ki drug drugemu konkurirata.

Poskusov, da bi sodelovanje izboljšali, je bilo več. Začeli so se že s tem, 
da je Univerza v Ljubljani postala soustanoviteljica IJ S (1970), IJ S pa pozneje tudi pridružen član ljubljanske univerze, posebej pa se jim je posvetila A R R S in razvila številne mehanizme sodelovanja. Danes morata na primer pri vsakem projektu, ki se prijavi na razpis AR RS, sodelovati vsaj dva partnerja iz različnih tipov ustanov, v večini primerov sta to partnerja $z$ inštituta in $z$ univerze. Partnerstvo ni zgolj simbolično, saj mora sodelujoča ustanova prejeti najmanj 20 odstotkov sredstev. Poleg tega je ARRS zaradi premajhne vključenosti inštitutskih raziskovalcev v pedagoški proces leta 2007 razvila sistem pedagoško-raziskovalnega sodelovanja. Pri tem je izhajala iz prepričanja, da je širjenje visoke ravni znanja, ki jo dosegajo slovenski inštituti, v nacionalnem interesu, prenos znanja na študente pa ena najučinkovitejših poti. Da bi dosegla čim večji učinek, je spodbude namenila obema stranema, raziskovalcem $\mathrm{z}$ inštitutov za dopolnjevanje njihovega raziskovalnega dela s pedagoškim in univerzam za vključevanje raziskovalcev $\mathrm{v}$ načrtovani pedagoški proces.

V slabih dveh letih je že več kot petina raziskovalcev najmanj petino svojega časa namenila poučevanju na univerzah. Če bi sistem deloval še nekaj let, bi na univerzah najmanj petino svojega časa poučeval že vsak raziskovalec $z$ inštitutov. Sledila bi odločitev, da ta delež povečamo na 40 odstotkov, s čimer bi dosegli zastavljena cilja: prenos bogatega znanja $\mathrm{z}$ raziskovalnih inštitutov na študente in bistveno višji raziskovalni delež na slovenskih univerzah. Toda reševanje tega strukturnega problema slovenske znanosti, ki je po mojem mnenju najbolj pereč, je prekinilo ministrstvo za znanost, ki ga je takrat vodil minister Golobič. Še danes ne vem, zakaj. Škoda, ki jo je ministrstvo s tem povzročilo, je velika; če bi mehanizem nemoteno deloval še naprej, bi bila slovenska znanost danes v povsem drugačni situaciji. Kot direktor ARRS sem ministru Golobiču takrat (septembra 2010) poslal dopis, v katerem sem med drugim zapisal: »Taka poteza bi po mojem mnenju pripeljala do resnih zapletov $\mathrm{v}$ financiranju znanosti in bi prekinila zelo uspešen instrument, ki ga izvaja ARRS. Moje osebno mnenje je, da je instrument vzpodbujanja pedagoško-raziskovalnega sodelovanja eden od naših najuspešnejših instrumentov in ga postavljam ob bok projektu mladih raziskovalcev in programskemu financiranju." (Demšar, 2010) Odziva ni bilo.

ARRS je problem neizkoriščenega raziskovalnega znanja slovenskih inštitutov in premajhnega raziskovalnega deleža v pedagoškem procesu univerz poskušala pozneje reševati še na druge načine, predlagala je na 
primer preoblikovanje Instituta "Jožef Stefan « v univerzo, kar bi verjetno pripeljalo do podobnega rezultata kot pedagoško-raziskovalno sodelovanje. A tudi ta pobuda se ni uresničila. Verjetno zato ne, ker so se nekateri zaposleni tako na univerzah kot na inštitutih bali, da bi proces preoblikovanja preveč posegel $\mathrm{v}$ delovanje utečenih sistemov in/ali da bi izgubili kakšno od ugodnosti, ki jih taka dvojnost nekaterim prinaša. Pa tudi zato, ker ni bilo prave politične volje. Minister Žiga Turk, ki je sicer predlogu prisluhnil, je vodil ogromno ministrstvo in za znanost žal ni imel dovolj časa, sodelavcev pa za ta primer ni pooblastil. Projekta preoblikovanja statusa I J S v univerzo sva se lotila skupaj, vendar se je minister zanj premalo zavzel, podobno kot tudi direktor inštituta, ki je projekt sicer odobraval.

Kdo pa se je pobudi najbolj upiral? Pravzaprav bi težko rekli, kdo, a strah, da bo sprememba prinesla tudi kakšne izgube, je vedno na delu. Tudi zato bi bile spremembe uresničljive le $z$ ministrom, ki bi se zanje resno zavzel in bi jih bil sposoben tudi izpeljati, vendar takega doslej žal še nismo imeli.

\section{Raziskovalce zdaj menda vabijo tudi tja, kjer jih prej niso marali}

Delo, 17. december 2009

\section{Pedagoško in raziskovalno delo končno na istem bregu}

Pred enim tednom smo $v$ prostorih Javne agencije za raziskovalno dejavnost Republike Slovenije (ARRS) spremljali tiskovno konferenco, na kateri so predstavili sodelovanje raziskovalcev $v$ raziskovalnih zavodih in drugih "čistih " raziskovalcev v pedagoškem procesu. Osrednjo vlogo pri tej predstavitvi so imele finančne spodbude (prvič uveljavljene lani jeseni, popolnoma pa letos, ko je za ta namen odmerjenih približno tri milijone evrov proračunskih sredstev), ki so jih za spodbujanje tega pretoka raziskovalcev že pred dvema letoma razvili v ARRS in jih doslej uspešno preizkusili.

O teh spodbudah smo v Delu v prejšnjih dneh že poročali. Toda na omenjeni tiskovni konferenci naši sobesedniki - dr. Franci Demšar, direktor ARRS, dr. Jadran Lenarčič, direktor Instituta "Jožef Stefan" (IJS), dr. Oto Luthar, direktor Znanstvenoraziskovalnega centra (ZRC) $S A Z U$, in prof. dr. Stane Pejovnik, rektor Univerze v Ljubljani (UL) - niso govorili samo o tem konkretnem spodbujevalnem mehanizmu, tem- 
več so, tudi v odgovorih na naša vprašanja, povedali še marsikaj zanimivega.

Kaj pričakujejo od omenjenega spodbujanja sodelovanja raziskovalcev v pedagoškem delu?

Demšar: Naša želja je, da bi v pedagoškem procesu sodelovala vsaj polovica vseh raziskovalcev inštitutov. Mnoge pregrade med univerzami in inštituti smo porušili, nastale bodo nove povezave, upam, da se bo to pokazalo tudi pri novih skupnih projektih.

Lenarčič: Močno verjamem, da je treba povezati raziskovalno in pedagoško delo. Od vsega začetka sem zatrjeval, da moramo to še dodatno spodbujati. [...] Po mojem prepričanju so bili inštituti in univerze pri nas v neki fazi preveč ločeni. Na IJs je habilitirana več kot polovica raziskovalcev, poleg dopolnilno zaposlenih jih vsaj še 120 pogodbeno sodeluje v pedagoškem procesu.

Pejovnik: UL ima že nekaj let sklenjene pogodbe s tremi največjimi naravoslovnimi in tehničnimi inštituti in v njih je opredeljeno sodelovanje raziskovalcev pri podiplomskem študiju, tako da ne potrebujejo več pedagoške habilitacije za mentorstvo pri doktoratih in magisterijih. To je, po moje - ob tem, kar je naredila agencija -, drugi najpomembnejši korak k boljšemu sodelovanju med inštituti in univerzami in, vsaj po mojem vedenju, tudi prvi resnejši korak pri podiranju plotov med inštituti in univerzami. Ne nazadnje zaposlitve inštitutskih raziskovalcev univerzam pridejo še posebno prav pri izvedbi visokospecializiranih predmetov, kjer je potrebno veliko raziskovanja.

Luthar: Pobudo ARRS vsekakor pozdravljam, a ob tem ne smemo pozabiti, da je razmišljanje, kako spodbuditi več sodelovanja, staro že vsaj 20 let. Uspeh ZRC SAZU pri vključevanju v pedagoški proces na univerzi je, o tem sem prepričan, tudi rezultat večje odprtosti naše institucije.

Katere so bile glavne ovire, ki so v preteklosti preprečevale tesnejše sodelovanje inštitutov in univerz?

Lenarčič: To je težko izmeriti, a občutek imam, da so bila pred nekaj leti vrata univerz inštitutom - in tudi vrata inštitutov univerzam veliko bolj zaprta kot danes.

Luthar: Pred 16 leti sem s kolegoma romal $k$ dekanu filozofske fakultete (FF). Predlagali smo mu zelo preprost način prehajanja iz ZRC $S A Z U$ na FF in nasprotno. Tedanji dekan FF, prof. dr. Frane Jerman, ki je bil nadpovprečno topel človek, je dejal, da je to super ideja, a da iz nje ne bo nič, ker univerza tega ne bo nikoli dopustila. [...] Sodelova- 
nje smo dvakrat ponudili tudi rektorici prof. dr. Kocijančičevi, njenemu predhodniku prof. dr. Mencingerju pa enkrat. Gospod Mencinger se za to ni pretirano zanimal, gospa rektorica pa nas je poslala na filozofsko fakulteto, češ da UL ne zanima sporazum na ravni univerze in ZRC SA$Z U$, da naj se zadovoljimo s sporazumom s fakulteto, čeprav vsaj toliko naših raziskovalcev, kot jih dela na FF, dela drugje. [...] Sam sem pred leti, za časa ministra Zupana, dal pobudo, da bi oba sistema uvrstili v neko skupno zakonodajo, da bi olajšali povezovanje, a se je ta ideja nato spremenila v nekaj drugega. Dobro pa bi bilo, da bi bila oba zakona komplementarna, da bi bili vsi prehodi tudi zakonsko olajšani.

\section{Zakaj ARRS dodatno financira le pedagoško delo raziskovalcev $v$ okviru njihove dopolnilne zaposlitve, ne pa tudi njihovega tovrstne- ga pedagoškega in honorarnega dela?}

Demšar: Naše mnenje je, da honorarni predavatelji odpredavajo in odidejo. Niso člani senata, ne živijo zares s kolektivom, to ni tesno sodelovanje $v$ vseh mogočih elementih. V tem primeru pa gre za dopolnilno razmerje, za veliko tesnejše sodelovanje. Predvidevam, da bo predvsem pri mlajših, pri docentih, trajalo dolgo vrsto let. Zato spodbujamo takšen način sodelovanja. Seveda pa nimamo nič proti, temveč smo zelo veseli tudi vsakega honorarnega sodelovanja. To je lahko prvi korak, ko pa univerza vidi, da je predavatelj v redu, mu ponudi resnejše oblike sodelovanja.

Pejovnik: Dopolnilno delovno razmerje je za fakultete in univerze dražje. Zanj moramo plačati več dajatev, je pa tudi trajnejše od pogodbenega delovnega razmerja. Večja zavezanost partnerjev je, kolikor vem, tudi razlog, da je ARRS izbrala to obliko.

Lenarčič: Upoštevati moramo med drugim osebne interese, zaradi katerih si nekateri, med njimi sem tudi jaz, raje izberejo pogodbeni odnos.

Luthar: Jaz ne predavam po pogodbi, ampak sem delno zaposlen na eni od univerz, da pokažem svojim kolegom, da se to da.

Ali so se na posameznih katedrah fakultet pokazali kakšni odpori proti večjemu zaposlovanju raziskovalcev z inštitutov?

Luthar: V primerjavi z ozračjem na univerzi pred kakšnimi 15 leti je sedanje res neverjeten napredek. Sicer pa bodo vedno razlike med posameznimi raziskovalnimi skupinami in katedrami.

Pejovnik: V celoti se strinjam, da imajo na fakultetah različne odnose do tega sodelovanja, vendar se je na splošno, to lahko trdim, v okviru 
univerze povečala pripravljenost za sodelovanje. Tudi pri nas je prevladalo védenje, da zaprtost sistema ne prinaša nič dobrega. V Evropi se veliki sistemi povezujejo, priča smo rasti mnogih univerz, tako da ljubljanska ne bo več dolgo ena večjih evropskih univerz, temveč bo sodila že med manjše.

Lenarčič: Dosedanje sodelovanje je bilo predvsem rezultat odnosov med posamezniki z univerz in inštitutov. Kadar kdo koga ni maral, ga niti ni pritegnil. Sedanje finančne spodbude so prinesle veliko spremembo. Tudi tisti profesorji, ki so prej za nekoga iz raziskovalnega inštituta govorili, da pri njih nikoli ne bo učil, zdaj kličejo in ga vabijo, naj pride predavat...

\section{Kako si predstavljajo prihodnje sodelovanje med inštituti in univer- zami?}

Pejovnik: Naš prostor je premajhen, da bi nekatere stvari po nepotrebnem ali celo po nemarnem podvajali. Iskati bomo morali možnosti za skupne nastope, pri tem pa si bom močno prizadeval, da nekatere oblike sodelovanja med univerzami in inštituti še bolj formaliziramo. $\mathrm{Ne}$ bi še razlagal, kako si predstavljam, ker je to dolg proces, $v$ katerem bo treba še veliko usklajevanja. Prizadevali si bomo tudi, da bi več povezav med univerzo in inštituti zagotovili na tistih področjih, ki še zaostajajo, torej $v$ družboslovju in humanistiki.

\section{Mednarodna usmeritev}

Ministrstvo in kasneje ARRS sta ves čas po osamosvojitvi s sofinanciranjem podpirala mobilnost profesorjev, raziskovalcev in študentov, $\mathrm{v}$ času krize leta 2012 pa so to finančno spodbudo ukinili. Ali bo akademska sfera iz svojih lastnih virov tej aktivnosti namenjala dovolj sredstev, bo pokazal čas.

Dostop do znanstvene literature je, kot smo že poudarili, eden od ključnih pogojev za kakovostno znanstveno delo. A R R zadnjih deset let preko univerzitetno-inštitutskih konzorcijev financira elektronski dostop do praktično vseh znanstvenih revij, ki v svetu izhajajo. Neposreden dostop do tako širokega nabora znanstvene literature seveda ni od vedno, pri nas se je postopoma vzpostavljal zadnjih 25 let. Država je v enem od številnih obdobij stihijskega varčevanja, v osemdesetih letih prejšnjega stoletja, na primer ukinila uvoz tuje znanstvene literature. Če starejše raziskovalce vprašate, po čem so si zapomnili tedanjega 
predsednika republiškega izvršnega sveta Janeza Zemljariča, vam bodo odgovorili, da po enoletni luknji na policah znanstvenih revij.

Poleg znanstvene literature so za znanstvenike pomembni tudi medsebojni stiki. Udeležba na mednarodnih znanstvenih konferencah je za raziskovalca pomembna tudi zato, ker se sreča s svojimi kolegi in profesorji, katerih dosežke pozna le iz literature. Neformalni pogovori med kolegi pogosto pomagajo premostiti prepreke pri izvedbi načrtov, za katere bi raziskovalci sicer rabili več let. Pred osamosvojitvijo so se slovenski raziskovalci udeleževali omejenega števila konferenc, v zadnjih 25 letih pa je večina znanstvenih ustanov $z$ vseh področij vzpostavila intenzivnejše tovrstne stike s svetom in tudi sama postala gostiteljica pomembnih mednarodnih konferenc.

V začetku osemdesetih je Z A M T E S finančno podprl krajše izmenjave naših in tujih raziskovalcev. Samostojna država, ki je zAM T E S priključila ministrstvu za znanost in pozneje ARRS, je financiranje izmenjav obdržala in tako spodbudila bogat razmah znanstvenega sodelovanja: več sto izmenjav letno $z$ več kot 30 državami.

Še pomembnejše oblike mednarodnega sodelovanja so daljša bivanja naših raziskovalcev v tujini (in tujih pri nas) ter izvajanje skupnih projektov, ki prinašajo merljive rezultate. Podatki v svetovnem merilu kažejo, da so najkakovostnejša in najbolj citirana znanstvena dela rezultat mednarodnega sodelovanja (Science Europe in Elsevier, 2013). To velja za vse države, še toliko bolj pa za manjše.

$\mathrm{Na}$ daljša bivanja $\mathrm{v}$ tujino so slovenski znanstveniki prvih deset let naše države hodili predvsem v Z D A, ki je z vrsto možnosti, od enoletnih štipendij (Fulbrightova, Fogartyjeva) do univerzitetnih fondov za te namene, to omogočala tudi že prej. V z D A, kjer je veljal (in bolj ali manj še vedno velja) nekakšen zlati standard za pomembne raziskovalne tematike in znanstveno kvaliteto, so odhajali tudi številni drugi raziskovalci iz Evrope. Po terorističnih napadih 11. 9. 2001 so se ZDA začele zapirati pred svetom, hkrati pa se je krepilo sodelovanje evropskih držav v okviru EU.

Glavni vzvod evropskega znanstveno-razvojnega sodelovanja so Okvirni programi za raziskave in tehnološki razvoj oziroma inovacije, ki so se začeli oblikovati v začetku osemdesetih let prejšnjega stoletja. Slovenija je sodelovala v Petem, Šestem in Sedmem okvirnem programu ter s sodelovanjem nadaljuje v okviru Obzorij, kot se ti programi imenujejo danes. Skupna sredstva, namenjena za programe, so se stalno višala in $\mathrm{z}$ njimi tudi višina sredstev, ki jih je $\mathrm{v}$ tekmovalnih postopkih pridobila 


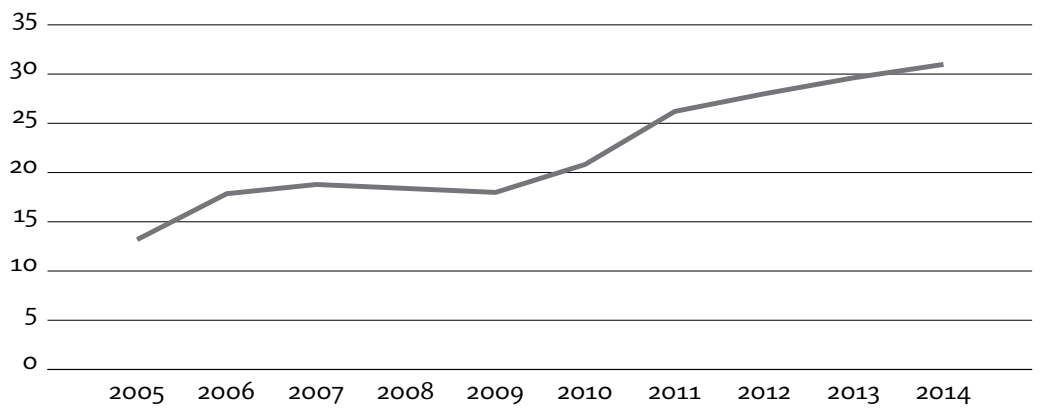

Slika 7.3 Mednarodna sredstva, ki so jih slovenske univerze in inštituti pridobili med letoma 2005 in 2014

V milijonih EUR. Po podatkih ARRS (https://www.arrs.gov.si/sl/analize/odlicnost).

Slovenija:

- 5. okvirni program (1998-2002): E U: 15 milijard, Slovenija: 40 milijonov;

- 6. okvirni program (2002-2006): E U: 17 milijard, Slovenija: 76 milijonov;

- 7. okvirni program (2007-2013): E U: 50 milijard, Slovenija: $171 \mathrm{mi}-$ lijonov;

- Obzorje (2014-2020): EU: 80 milijard.

Programe so zasnovali, da bi pripomogli h gospodarskemu napredku, zato prejme velik delež sredstev tudi gospodarstvo. Slika 7.3 prikazuje višino sredstev, ki so jih slovenske univerze in inštituti pridobili iz mednarodnih virov, pri čemer prevladujejo sredstva Okvirnih programov. Podatki izkazujejo visoko rast pridobljenih sredstev v zadnjem desetletju.

Slovenija je bila v pridobivanju sredstev Okvirnih programov uspešna, na število prebivalcev je pridobila nekoliko več, kot je evropsko povprečje, medtem ko je po višini pridobljenih sredstev glede na to, koliko sredstev je sama vložila v E U (sorazmerno z B D P), v samem vrhu držav E U, kar razberemo iz slike 7.4 na naslednji strani, ki prikazuje skupne vrednosti 6. in 7. okvirnega programa.

AR R S je z upoštevanjem ocenjevalnih postopkov drugih ustanov razvila tudi več uspešnih načinov financiranja mednarodnih projektov. Financirala je slovenske partnerje $\mathrm{v}$ mednarodnih projektih, ki jih je izbrala Evropska znanstvena fundacije (E S F). Sodelujoče države so finan- 


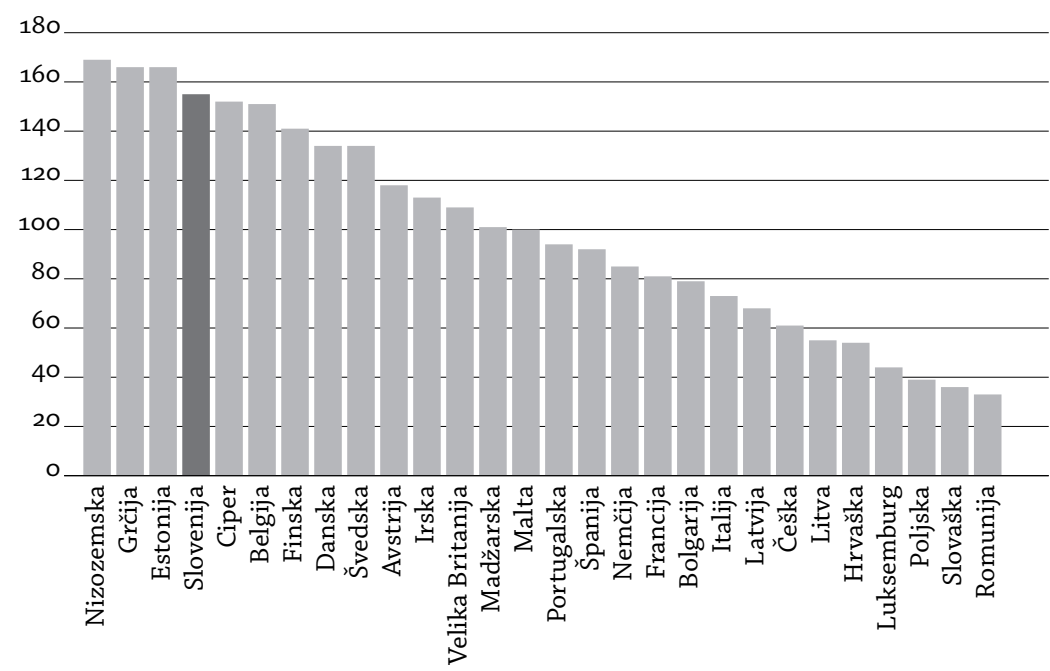

Slika 7.4 Višina pridobljenih sredstev 6. in 7. okvirnega programa glede na vložek države, ki je sorazmeren B DP (juste retour)

Po podatkih Evropske komisije (http://ec.europa.eu/research/index.cfm).

cirale partnerje projektov iz njihovih držav. Sodelovanje se je končalo leta 2016, ko je fundacija prenehala delovati. Druga oblika učinkovitega mednarodnega sodelovanja poteka po shemi vodilne agencije, ki deluje tako, da se dve državi dogovorita, da objavita skupni razpis, pri čemer ena izpelje postopek izbire projektov, druga pa potrdi izbor in se obenem obveže, da bo financirala partnerja iz svoje države. Slovenija vsako leto objavlja razpise skupaj z Avstrijo, Belgijo in Madžarsko. Tretjo pot za financiranje mednarodnih projektov pa je odprla zaveza Slovenije, da $\mathrm{z}$ nekoliko manjšimi sredstvi financira projekte slovenskih prijaviteljev, ki so bili na razpisih Evropskega raziskovalnega sveta (E RC) dobro ocenjeni, vendar niso bili izbrani.

Vsi ti instrumenti financiranja so rezultat sodelovanja A R R z evropskimi raziskovalnimi agencijami, združenimi v fundaciji E S F oziroma $\mathrm{v}$ njenem nasledniku, združenju Science Europe, katerega ustanovni član je tudi ARRS. ARRS se je v obeh ustanovah zelo uveljavila, sam sem kot večletni član vodstva obeh ustanov spodbujal popularizacijo instrumentov Vodilne agencije in sodeloval pri razvijanju projekta Pametna specializacija, ki raziskovalna sredstva namenja bivšim vzhodnoevropskim državam. Fundacija ES F je leta 2010 izvedla zunanjo evalvacijo ARRS in jo laskavo ocenila (European Science Foundation, 2011b). Slovenski znanstveni in inovacijski sistem je ocenjevalo tudi več drugih 
mednarodnih ustanov, kot sta O E CD (2012) in Evropska komisija (Meijenfeldt, 2010; Reid in Stanovnik, 2013).

Slovenija se je po osamosvojitvi aktivno vključevala v nekatere mednarodne raziskovalne programe, postala je polnopravna članica Evropske organizacije za jedrske raziskave (C E R N), pridružena članica Evropske vesoljske agencije, sodeluje v projektih preučevanja osnovnih delcev (B E L L E na Japonskem) in na observatoriju Pierra Augera v Argentini. Slovenski znanstveniki so za raziskave v okviru organizacij CERN in BE L LE, ki so prejele Nobelovo nagrado, prispevali pomemben delež. $V$ zadnjem času v E U za spodbudo znanstvenemu delovanju omogočajo tudi uporabo evropske raziskovalne infrastrukture, ki jo med drugim ponujajo projekti Evropskega strateškega foruma za raziskovalne infrastrukture (E SFRI).

\section{Dvorezna Busquinova zapuščina}

Delo, 19. avgust 2004

Čeprav je dr. Janez Potočnik uradno zaenkrat šele kandidat za mesto evropskega komisarja za znanost in raziskave, glede na dosedanjo prakso skoraj ni dvoma, da bo Barrosova odločitev obveljala tudi po oktobrskem zaslišanju in glasovanju v evropskem parlamentu. Več dvomov pa je lahko o tem, ali bo lahko Potočnikovo delovanje vsaj približno tako učinkovito in odmevno, kot je bilo od začetka delo sedanjega komisarja Philippa Busquina.

Ne smemo namreč pozabiti, da se bo petletni mandat Evropske komisije sicer novembra res začel znova, a da to nikakor ne velja za delovne programe posameznih področij, med katerimi je področje znanosti in raziskav še nekaj čisto posebnega.

Busquin, ki je svojo kariero začel v znanosti - pred vstopom v komisijo pa bil dolga leta član belgijske vlade - leta 1999, ko je postal evropski komisar, o razmerah na področju evropskih raziskav, kot je pred dvema letoma sam povedal v pogovoru za Delo, ni vedel prav veliko. A se je odločil, da svojega dela ne bo omejil zgolj na nezanimivo razdeljevanje evropskih raziskovalnih sredstev, ampak bo korenito spremenil evropsko raziskovalno politiko.

Izhajal je iz analize, ki je pokazala, da se za evropske raziskave namenja premalo denarja, da ima Evropa le nacionalne raziskovalne programe, ne pa tudi skupnega, in da manjka učinkovit prehod intelektualnega raziskovalnega potenciala $v$ gospodarsko uporabne izdelke in storitve. 
Na podlagi teh spoznanj je Busquin Evropski komisiji predlagal dokument o skupnem evropskem raziskovalnem prostoru, ki je bil objavljen januarja leta 2000 na srečanju petnajsterice v Lizboni. To je bilo tudi prvikrat $v$ zgodovini $E U$, da so o znanosti razpravljali na samem evropskem vrhu.

Še aktualni evropski raziskovalni komisar zato upravičeno velja za izumitelja evropskega raziskovalnega prostora, neuradno pa tudi za poglavitnega pobudnika tako imenovane Lizbonske strategije, ki bo vodilni strateški dokument tudi v naslednjem obdobju delovanja komisije. Navsezadnje je prav Busquin prvi - že aprila 2002, kot je povedal za našo prilogo - $v$ Barceloni predlagal Evropski komisiji, da naj delež financiranja raziskovanja in inovacij do leta 2010 dvigne na tri odstotke $B D P$.

Sedanji izredno visoki evropski proračunski delež za raziskave, ki je že četrti med vsemi resorji, a naj bi se v naslednjem proračunskem obdobju po načrtih celo še podvojil, je torej precej rezultat izredno spretnega lobiranja tega politika, čeprav so mu pri prepričevanju gotovo krepko pomagale razmere v evropskem in svetovnem gospodarstvu.

$V$ Busquinovo dediščino zagotovo sodi izredna skrb za dvig odličnosti evropskih raziskav in za izboljšanje pogojev za delo mladih raziskovalcev, hkrati s prizadevanjem, da le-ti ne zapustijo Evrope, temveč da $v$ centre raziskovalne odličnosti privabijo še raziskovalce iz drugih delov sveta. Izkazal se je tudi s podporo projektom za zagotavljanje optimalne vloge žensk $v$ znanosti in za čim večjo izrabo raziskovalnih potencialov $v$ novih članicah $E U$.

Dosedanji komisar, ki jev zadnjih letih kot nekak raziskovalni mesija prepotoval vso Evropo in se ob tem srečaval z raziskovalci, s politiki in $z$ novinarji, je tako postal že utelešenje ERE oziroma evropskega raziskovalnega prostora. Naj bi mu kdo oporekal karkoli, izredne zavzetosti za uresničenje postavljenih ciljev mu vsekakor ne bi mogel.

Čeprav se mnogim zdijo nekateri cilji nestvarni - zlasti načrtovani delež BDP za raziskave -, je vsekakor dejstvo, da je zelo veliko že narejenega. Evropa prav letos dobiva mrežo centrov raziskovalne mobilnosti in evropski znanstveni svet, namenjen spodbujanju temeljnih raziskav, ima pa tudi že razvejano mrežo centrov raziskovalne mobilnosti.

Evropski okvirni raziskovalni program je ob tem dobil bistveno večje razsežnosti, še večje spremembe se obetajo novemu 7. okvirnemu programu evropskih raziskav. Ta naj bi še neposredneje podprl nastajanje evropskega raziskovalnega prostora oziroma Lizbonsko strategijo. $\mathrm{Ob}$ 
tem naj bi večjo vlogo dobili preostali neodvisni evropski raziskovalni programi, med njimi program industrijskih raziskav Eureka.

Razumljivo (pre)veliko navdušenje $v$ slovenski raziskovalni sferi in zunaj nje, da bo Slovenec upravljal evropsko znanost, bo, upajmo, uravnotežila Potočnikova priznana pragmatičnost. Upajmo, da bo to vključevalo tudi spoznanje o tem, da je Busquinova ministrska dediščina zelo bogata in je prav zato ne bo mogoče zlahka upravljati.

Seveda, Potočnik ima vse možnosti, da jo oplemeniti s svojimi zamislimi in da marsikaj, kar se je že ali se bo še izkazalo za zgrešeno, popravi. A prav gotovo je, da bi bilo njegovo prihodnje delo neprimerno enostavnejše, če se ne bi pred petimi leti pojavil Belgijec, ki je imel svojo vizijo, ki je zdaj evropska.

Novi evropski premier se je tega gotovo zavedal tudi pri razdeljevanju portfeljev. To pa pomeni resnično veliko priznanje našemu komisarju.

\section{Transparentnost}

Razvoj znanosti in posledično vsega človeštva je neločljivo povezan $s$ transparentnostjo. Zakaj? Osnova transparentnosti je vidnost ne le rezultatov neke dejavnosti, ampak tudi postopkov, ki so do rezultatov pripeljali. Gibalo njenega razvoja pa je sposobnost človeka, da svoja spoznanja sporoča drugim, jih prenaša na naslednje generacije in tako omogoča, da človeštvo lahko znanje črpa iz skupnega bazena, s čimer se odvija nekakšen proces skupinskega učenja (Christian, 2010). Zgodovina tega procesa je povezana $\mathrm{z}$ razvojem jezika ter $\mathrm{z}$ izumi pisave, papirja, tiska in interneta. Za razvoj znanosti in njenega družbenega položaja - v sodobni družbi igra bistveno vlogo - pa so pomembni še nastanki univerz in akademij znanosti ter predvsem sistema znanstvenega objavljanja.

Prelomnico v sistemu znanstvenega objavljanja lahko postavimo v leto 1660 , ko je bilo ustanovljeno Royal Society of London for Improving Natural Knowledge (Royal Society), društvo znanstvenikov predvsem s področij matematike in naravoslovja, ki je vpeljalo pomembno novost. Znanstvene informacije so se dotlej širile le s predavanji na univerzah in objavljanjem knjig, Royal Society pa je uvedel tedenska srečanja, na katerih so znanstveniki odprto razpravljali o novih idejah, ki so jih demonstrirali tudi z znanstvenimi eksperimenti. Srečanja so postala predhodnica dejavnosti nacionalnih akademij znanosti in drugih profesionalnih združenj - znanstvena komunikacija na kongresih, seminarjih, ko- 
lokvijih, rednih srečanjih je danes seveda samoumevna stalnica. Tajnik združenja Henry Odenburg se je leta 1665 odločil, da glede transparentnosti komunikacije in predstavitve novih znanstvenih dognanj stopi še korak dlje. Predavanja rednih tedenskih sestankov je na šestnajstih straneh natisnil v brošuri, ki jo je poimenoval Philosophical Transactions of the Royal Society. Brošura, ki so jo od takrat tiskali vsak mesec, izhaja še danes in velja za eno od dveh (nekaj mesecev prej je izšla francoska revija Journal des sçavans) začetnic znanstvenih revij na svetu. Že naslednje leto je Isaac Newton v njej objavil študijo loma svetlobe skozi prizmo.

Znanstvene revije so danes daleč najbolj razširjen način objavljanja znanstvenih spoznanj. Še vedno, čeprav vse manj, se predvsem v humanistiki objavljajo znanstvene knjige, posebna kategorija, podobna znanstvenim monografijam, so še teze - doktorske disertacije ali habilitacijska dela. Vendar so tudi znanstvene monografije in teze pogosto podobne znanstvenim revijam, včasih so teze celo predvsem zbirka člankov, monografije pa zborniki s prispevki, ki imajo vse lastnosti člankov. Danes izhaja 30.000 znanstvenih revij, ki v enem letu objavijo več kot dva milijona člankov - števili revij in člankov se podvojita povprečno vsakih 20 let. Skupno število do zdaj objavljenih člankov je 50 milijonov. Znanstvene revije so večinoma specializirane, zelo redke pa objavljajo izsledke $\mathrm{z}$ vseh znanstvenih področij - najbolj znani in najboljši tovrstni reviji sta Nature in Science.

$V$ čem se znanstveni članki že od začetka, sčasoma pa vse izraziteje razlikujejo od drugih člankov in $\mathrm{v}$ čem znanstvene monografije od drugih knjižnih del? Njihov ključni razlikovalni element je transparentna predstavitev rezultatov: podani morajo biti tako, da postopke, ki so do njih pripeljali, lahko vsakdo ponovi, torej rezultate preveri. Tako so bili zasnovani že prvi prispevki, ki so se osredotočali predvsem na empirične ugotovitve, medtem ko je bilo interpretacij in teorij le malo. Članki sprva niso imeli formalne strukture oziroma delitve na poglavja. To se je začelo uveljavljati v 18. in še izraziteje $\mathrm{v}$ 19. stoletju: prispevki so se členili na uvod, glavni del in zaključek, pomembno mesto pa je ob predstavitvi argumentov dobila interpretacija rezultatov. Metode raziskovanja so bile podrobno opisane, raziskovalni postopek, ki je do rezultatov pripeljal, pa nazorno predstavljen.

Nove znanstvene revije so te principe posvojile in jih nadgrajevale. Da bi se izognili morebitnim manipulacijam, so uvedli strog sistem citiranja in presojo kolegov. V 18. stoletju se je tako uveljavilo navajanje virov, 
ki so pomembni za nastanek znanstvenega članka, in od leta 1731 tudi institut anonimnih recenzentov, ki so pred objavo članek prebrali, ga priporočili za objavo, zahtevali dopolnitev ali pa ga argumentirano zavrnili. Tak sistem je prva uvedla revija Medical Essays and Observations, ki jo je izdajalo društvo Royal Society of Edinburg. Članki so v 17. in 18. stoletju le izjemoma navajali formule, so pa že vse od začetka vsebovali ilustracije, medtem ko so grafikone začeli dodajati šele v 19. stoletju. V tem stoletju sta se uveljavila tudi navajanje tistih, ki so poleg avtorja sodelovali pri raziskavi, in avtorjeva zahvala za njihov prispevek. V tristopetdesetletnem razvoju znanstvenega objavljanja se je tako izoblikoval koncizen, neoseben način predstavitve rezultatov. Danes za znanstveno objavljanje na večini področij velja enostaven standard IMRAD, ki ni nič drugega kot kratica za strukturo članka: Introduction, Methods, Results and Discussion. Revije so bile in so še vedno prosto dostopne $\mathrm{v}$ univerzitetnih knjižnicah.

Hkrati s standardizacijo znanstvenega objavljanja so univerze, ki so bile glavni prostor raziskovanj, začele principe znanstvenega objavljanja prenašati tudi na interne univerzitetne postopke. Doktorske disertacije so postajale strukturno vse podobnejše znanstvenim člankom. Enako seveda velja tudi za znanstvene monografije. Nekatere univerze so šle še korak dlje in predpisale, da mora biti doktorska disertacija izključno zbirka znanstvenih člankov kandidata. Podobno je bilo s habilitacijami.

Ocenjevanje doktorskih del in ocenjevanje kandidatov pri habilitacijskih postopkih bi lahko primerjali z ocenjevanjem ustreznosti znanstvenih člankov za objavo. Ocenjevalci si povsod postavljajo podobna vprašanja: kakšni so rezultati kandidata, kakšen je njihov pomen za razvoj znanosti, koliko so rezultati pomembni v širšem družbenem kontekstu, kako je znanstveno delo napisano, ali je metodološko nesporno, ali so postopki preverljivi. Toda ocenjevalci pri kandidaturi, drugače kot pri člankih, preverjajo tudi, kakšen odmev je imelo kandidatovo znanstveno delo po objavi. Ga je kdo vgradil v nove dosežke oziroma citiral? Je teh citatov veliko in gre očitno za pomemben znanstven preboj? Ali so posledice vidne tudi na tehnološkem področju, v prenosu znanja v medicinsko prakso, v širšem družbenem ali kulturnem okviru? Prav ti elementi, na katerih temelji tudi transparentnost, so omogočili večjo učinkovitost univerzitetnega sistema, a ne zgolj kratkoročne formalne učinkovitosti - marsikateremu zunanjemu opazovalcu se zdi življenje na univerzi morda celo lagodno, tudi kaotično -, pač pa dolgoroč- 
no učinkovitost, ki je postavila osnovo za ključne premike, kakršni se v zadnjih stoletjih dogajajo v svetu.

Naslednja stopnja $\mathrm{v}$ razvoju transparentnosti $\mathrm{v}$ znanosti je povezana $\mathrm{z}$ ustanovitvijo raziskovalnih agencij po drugi svetovni vojni. Principe transparentnosti, na katerih so temeljile znanstvene revije in univerze (transparentnost rezultatov projektov in transparentnost ocenjevalnih postopkov), so raziskovalne agencije vgradile $\mathrm{v}$ principe svojega delovanja, hkrati pa jim dodale še en bistven element - transparentnost financiranja.

Naraščanje števila člankov, raznolikost raziskovalnih področij, raznovrstnost raziskovalnih možnosti posameznikov - vse to je sprožilo dilemo, ali za habilitacijski postopek zadostuje presoja kolegov o kandidatovem znanstvenem delu ali bi za odločitve potrebovali dodatne informacije. Dostop do dodatnih informacij je prinesel razvoj bibliometrije. Leta 1960 je Eugene Garfield ustanovil Inštitut informacijskih znanosti (Institute for Scientific Information) - leta 1992 ga je kupila korporacija Thomson Reuters (današnji lastnik je Clarivate Analytics) -, ki vzdržuje mednarodno bazo Web of Science (wo s). Gre za vrsto bibliografske baze, ki vsebuje podatke o znanstvenih člankih, objavljenih v zadnjih več kot petdesetih letih, tudi podatke o citiranju, torej o odmevnosti znanstvenih objav. Ker je odmevnost znanstvenih del večinoma sorazmerna $\mathrm{z}$ njihovo kvaliteto, je $\mathrm{z}$ uporabo baze wos mogoče statistično spremljati raziskovalno produkcijo in kvaliteto raziskovalcev, zmogljivost raziskovalnih področij, kakovost znanstvenih revij, univerz, mest, držav ... Izkaže se, da so nekateri znanstveni članki več tisoč- ali celo desettisočkrat citirani. Ta podatek je pomemben ne le za raziskovalca, ki je članek napisal, saj s tem lahko preveri, kako plodna so bila njegova spoznanja, niti samo za informacijo o gradivu, ki obravnava določno tematiko, kar je uporabno pri njenem preučevanju in iskanju ustrezne znanstvene literature, pač pa tudi za merjenje kvalitete. Število citatov namreč govori o pomenu in teži znanstvenega dosežka, o njegovi izjemnosti. Seveda pa je treba podatke razbirati premišljeno, saj se raziskovalna področja glede na citatnost zelo razlikujejo, pomembna pa je tudi časovna dinamika.

Še prodornejša od Inštituta informacijskih znanosti je konkurenčna ustanova Elsevier $\mathrm{z}$ bazo podatkov Scopus, ki obravnava več kot 20.000 znanstvenih revij, pri čemer manj posega v zgodovino kot wo s, saj obdeluje prispevke, ki so bili objavljeni po letu 2004. Verodostojnejša je glede podatkov o raziskavah v družboslovju, saj ima v svoji bazi bistveno 
večje število evropskih znanstvenih revij, v humanistiki pa celo revije, ki izhajajo v nacionalnih jezikih (in ne zgolj v angleščini), zato omogoča tudi merjenje odmevnosti, ki ga baza wos za to področje ne premore (Bartol, Budimir, Smrekar, Pusnik in Juznic, 2014). Baza Scopus je zaradi povezave z največjo svetovno znanstveno založbo Elsevier poleg tega cenejša kot wos. Glede na doseg je večja tako od wos a kot Scopusa le še baza Google Scolar, a je po drugi strani v primerjavi z njima manj zanesljiva in sistematična.

Vsa ta orodja, ki omogočajo večjo transparentnost rezultatov in njihovo medsebojno primerljivost $\mathrm{v}$ svetovnem merilu, so seveda sijajna podpora univerzam. Kako delujejo v državi, kot je Slovenija, ki ima zgolj dva milijona prebivalcev? V takih primerih se majhnost izkaže za prednost, saj se lahko projekte, ki so v večjih državah izvedljivi edino v domeni univerz, izpelje na nacionalnem nivoju. Eden od takih je tudi coBIS S (kooperativni online bibliografski sistem in servisi), izviren slovenski bibliografski sistem. Njegovi začetki segajo v leto 1984, leta 1991 pa je dozorel do te mere, da je slovenska vlada del centra, ki se je specializiral za bibliografske informacije, preoblikovala v samostojni zavod I Z U M. Za razliko od drugih svetovnih bibliografskih sistemov ima COBIS S vgrajenih vrsto varovalk, ki preprečujejo, da bi prišlo do napak pri bibliografskih podatkih, in omogočajo, da je vsaka publikacija v Sloveniji pripisana tistemu raziskovalcu ali skupini raziskovalcev, ki jo je napisal(a). Ker je povezan s sistemoma wos in Scopus, ponuja ne le informacije o vseh objavljenih prispevkih (člankih, knjigah, zbornikih, predavanjih, patentih ...) vsakega slovenskega raziskovalca, ampak tudi podatke o njihovi citiranosti v drugih delih. Ker vse to velja za vsako publikacijo in vsakega znanstvenika posebej, lahko na podlagi teh podatkov razbiramo tudi odmevnost ali uspešnost posameznih projektnih ali drugih raziskovalnih skupin, fakultet, univerz, inštitutov. Poleg tega je sistem nadgrajen s primerjavami med področji in relativnim faktorjem vpliva.

V prvem, poskusnem obdobju je bilo vnašanje bibliografij v CO B IS S prostovoljno, ko pa je do leta 1998 sistem tudi v praksi potrdil svoje teoretične prednosti, je sledila uvedba obveznega vnosa raziskovalnih rezultatov oziroma bibliografij raziskovalcev. Ta korak je omogočil nadaljnji razvoj mehanizmov ocenjevanja. V slabem poldrugem desetletju se je v bazi Сов IS S nabralo za dobra dva milijona bibliografskih enot slovenskih raziskovalcev, kar pomeni, da imamo ogromno bibliografsko bazo, ki je ne le v pomoč komisijam pri ocenjevanju in delitvi sredstev, 


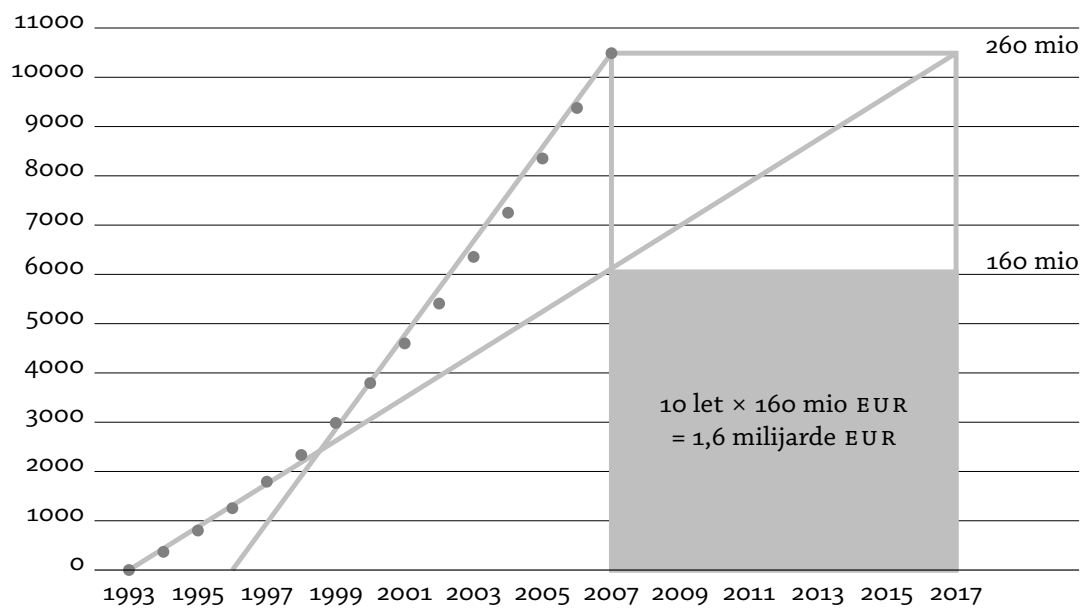

Slika 7.5 Kumulativna rast števila slovenskih člankov v mednarodni bazi wo S

Pike - kumulativno število slovenskih člankov v mednarodni bazi w os (lestvica na levi). Grafikon prikazuje proračun A R R za leto 2007 in višino sredstev, ki bi jih potrebovali, če bi hoteli vzdrževati povečano rast števila znanstvenih publikacij le z dodatnimi proračunskimi sredstvi. Povzeto po Demšar (2013).

ampak je tudi orodje, s katerim si raziskovalci lahko pomagajo pri projektiranju novih raziskav. $S$ takšnim bogastvom znanja se ne more hvaliti vsak, na dejstvo, da to znanje ni le nakopičeno, ampak tudi uporabno organizirano, pa smo lahko ponosni prav tako, kot smo ponosni na slovenske naravne danosti ali na vsakega športnika, ki v danem trenutku s svojimi uspehi promovira Slovenijo v svetu.

Podrobna preglednost bibliometrijskih rezultatov v svetovnem merilu, ki je omogočila medsebojne primerjave tudi za slovenske raziskovalce, je močno vplivala na raziskovalno kulturo slovenskih raziskovalcev, izbirnih postopkov ARRS in habilitacijskih postopkov na univerzah in institutih (Demšar, 2013). Slika 7.5 ponuja vpogled v učinek uporabe baze COBISS na rast znanstvene kvalitete in na raziskovalno dejavnost $\mathrm{v}$ Sloveniji.

Iz slike 7.5, ki prikazuje pričakovano in dejansko rast objav slovenskih raziskovalcev od leta 1993 do leta 2007, lahko razberemo, da bi v primeru, da bi ves ta čas veljal nekdanji sistem objavljanja, A R R S leta 2007, ko je bil njen proračun približno 160 milijonov evrov, s financiranjem projektov uspela slovenskim raziskovalcem zagotoviti dobrih $4.000 \mathrm{znan}-$ stvenih objav manj. Ali drugače: če bi po starem sistemu želeli zagotoviti dejansko število objav v letu 2007, bi za to potrebovali proračun v višini 
260 milijonov evrov. In ker že nekaj časa tako kot drugje po svetu tudi v Sloveniji radi gledamo skozi oči davkoplačevalcev, lahko mirno rečemo, da smo z uvedbo transparentnosti na področju znanstvenega raziskovanja samo leta 2007 privarčevali 100 milijonov evrov davkoplačevalskega denarja. Mogoče je razlaga res malce poenostavljena, a kljub temu lahko zagotovo trdim, da brez uvedbe sistema с О в Is s leta 1997 in uveljavitve obveznega vpisovanja strokovnih del najverjetneje ne bi prišlo do takega povečanja znanstvene produktivnosti. Rast bi bila namreč taka, kot je bila v času pred sistemom С О B IS S, torej počasnejša, kar pomeni, da bi raven znanstvene produkcije iz leta 2007 dosegli šele leta 2017. Tako se je s sistemom сов ISs, ki za infrastrukturno oskrbovanje znanosti letno porabi približno milijon evrov, "prihranilo« vsaj deset let financiranja znanosti, torej $10 \mathrm{x} 160$ milijonov evrov ali 1,6 milijarde evrov.

Uspeh sistema сов ISs, ki se je izkazal kot zanesljivo in uporabno bibliometrijsko orodje, je leta 1999 spodbudil zagon sistema SICRIS slovenskega sistema sprotnega spremljanja raziskovalne dejavnosti. SICRIS zajema osnovne podatke vsakega raziskovalca, raziskovalne skupine ali raziskovalne organizacije - sem spadajo kontaktni podatki, kot so telefonske številke in spletne strani, pa tudi tekoči in že zaključeni projekti s povzetki in standardiziranimi izjemnimi dosežki ter povezave $\mathrm{z}$ bazami, ki omogočajo vpogled $\mathrm{v}$ integralna besedila raziskav. Če imajo raziskovalci na voljo video predstavitve, so dostopne tudi te.

Poenoten format bibliografij raziskovalcev, ki se je vzpostavil s sistemom СО В ISS - v bazi je sistematično predstavljenih okoli 15.000 raziskovalcev -, je sicer dragoceno ocenjevalno orodje, ne pove pa dovolj o konkretnih rezultatih raziskovalnega dela, ki so še posebej zanimivi za splošno javnost oziroma tisti njen del, ki predstavlja potencialne uporabnike tega znanja, na primer gospodarske družbe. Zato je sistem SICRIS, ki vsebuje tudi vsebinske informacije o projektih, pomembna nadgradnja bibliografskega sistema C О B IS S in postaja iz leta v leto pomembnejši in nepogrešljivejši, kar potrjuje tudi obisk spletne strani, ki vse bolj narašča. Podobno nepogrešljivi postajajo tudi ponudniki videovsebin, kot so Video lectures, Digitalna knjižnica in Atlas znanosti (glej https://www.arrs.gov.si/sl/povezave.asp).

Uporaba bibliometrijskih metod je močno vplivala na rast znanstvene kvalitete. Ob osamosvojitvi Slovenije je bila še razmeroma skromna, kar je narekovalo preučevanje vzorcev znanstvenega objavljanja drugod po svetu. IZUM je omogočil, da so slovenski raziskovalci in ARRS s sistemoma COBISS in SICRIS dobili neposreden vpogled $\mathrm{v}$ raziskovalno 
aktivnost vsakega posameznika in raziskovalne enote. Tak neposredni vpogled je pomagal $\mathrm{k}$ spremembi kulture objavljanja, $\mathrm{k}$ stremljenju $\mathrm{k}$ mednarodno primerljivi kvaliteti. A R RS podatke uporablja pri ocenjevalnih postopkih, univerze pri habilitacijah. Seveda se način uporabe $\mathrm{z}$ leti spreminja - če se je pred desetletjem bibliometrijo uporabljalo za glavni kriterij pri dodeljevanju sredstev, je danes, ko smo se povzpeli v zgornjo tretjino držav E U, primernejša za določanje vstopnih kriterijev za prijavitelje projektov in za kandidate mentorjev mladih raziskovalcev.

Transparentnost znanstvenega delovanja ja ARRS opredelila v Pravilniku o postopkih (so)financiranja, ocenjevanja in spremljanju izvajanja raziskovalne dejavnosti, smiselno pa bi jo bilo zapisati tudi v Zakon o raziskovalni in razvojni dejavnosti.

\section{Tudi v znanosti ni vse javno}

Delo, 24. februar 2011

Vabilo na nedavno nujno sejo odbora državnega zbora za visoko šolstvo, znanost in tehnološki razvoj z eno samo točko dnevnega reda - skrivanje informacij pred javnostjo na Agenciji za raziskovalno dejavnost $R S$ (ARRS) - je vzbujalo vtis, da gre za obsojanja vredno zadevo. Navsezadnje se ravno omenjena agencija, kar ob vsaki priložnosti poudarja njen doslej edini direktor Franci Demšar, ponaša z izjemno transparentnostjo svojega dela, kar, seveda, pomeni tudi transparenten pretok informacij. Na spletni strani ARRS je res mogoče videti vse faze postopkov izbire projektov in tudi vseh drugih postopkov, v katerih se delijo javna sredstva.

Samo po sebi se je torej ob omenjenem vabilu postavilo vprašanje, č je deklarirana transparentnost ARRS morda le fasada, ki prikriva skrivanje informacij. Bomo priča aferi, ki bo pokazala, da tudi znanost ni imuna za slabosti drugih družbenih področij?

Toda ko se je na seji odbora razkrilo, da sta direktor ARRS Franci Demšar in zaradi objektivne odgovornosti tudi minister Gregor Golobič obtožena zaradi neizvršitve odločbe informacijske pooblaščenke, $k i$ je ARRS naložila, da prosilcu, zgodovinarju dr. Igorju Grdini, omogoči vpogled $v$ množico informacij, med katerimi so tudi imena in priimki recenzentov z ocenjevalnih listov konkretne prijavne vloge, je zadeva dobila povsem drugačno dimenzijo. 
Kajti kot so na omenjeni seji pokazali težko ovrgljivi argumenti, bi zahtevana razkritja pomenila, da ima Slovenija glede anonimnosti recenzentov $v$ znanosti drugačna pravila, kot jih ima ostali znanstveni svet. O upravičenosti razkritij bo sicer dokončno odločilo upravno sodišče.

Ne glede na pravni razplet pa lahko $v$ vsakem primeru postavimo vprašanje, kako se je lahko zgodilo, da je resorni odbor DZ o tej temi razpravljal več kot teden pred iztekom tridesetdnevnega roka po prejemu odločbe, v katerem bi morali v ARRS, po nalogu informacijske pooblaščenke, prosilcu omogočiti vpogled v omenjene dokumente.

Za to prehitevanje gotovo ni kriva informacijska pooblaščenka, saj je njena namestnica na seji odbora sama izpostavila, da pravni rok še ni potekel. Očitno se je torej neznansko mudilo predlagateljem te razprave, torej poslanski skupini SDS, ki ji pripada tudi predsednik odbora za visoko šolstvo, znanost in tehnološki razvoj, Branko Grims.

Nima smisla ugibati o razlogih, zakaj razprava ni mogla počakati na zaključek pravne obravnave, kot bo lahko zdaj, ko so jo v odboru uradno prekinili. Vsekakor pa je zelo očitno sovpadanje med omenjeno pobudo in aktualno politično razpravo o zakonu o arhivih. Toda $v$ tem primeru je omenjeni del politike očitno podcenil znanstvenoraziskovalno sfero.

Očitno se je preveč zanašal na dejstvo, da sta tako ARRS kot njen direktor Franci Demšar pogosto deležna očitkov s strani naših raziskovalcev, ki se jim je nedavno pridružilo tudi računsko sodišče, ki je v poslovanju agencije odkrilo določene nepravilnosti. Seveda že po naravi stvari ARRS, ki že šesto leto razporeja velik del proračunskega deleža na tem področju - pri tem pa je verjetno več tistih, ki so bolj ali manj razočarani nad izbiro oziroma odmero denarja za njihovo raziskovalno delo, kot tistih, ki so z odločitvami ARRS povsem zadovoljni-, ne more biti posebno priljubljena institucija.

Resorno ministrstvo že napoveduje zakonske spremembe, ki bodo vplivale tudi na nadaljnje delo agencije. Spremembe v ARRS napovedujejo tudi posamezni, z agencijo povezani raziskovalci - med najkritičnejšimi ocenjevalci njenega dela je zagotovo prav sedanji predsednik znanstvenega sveta ARRS, prof. dr. Vito Turk. O tem so se lahko prepričali tudi bralci naše priloge.

Toda $v$ tem primeru tako zanj kot tudi za drugega na seji odbora $D Z$ prisotnega predstavnika raziskovalne sfere, namreč direktorja $Z R C$ SAZU dr. Ota Lutharja, očitno ni bilo nobene dileme. Popolnoma sta podprla Demšarjevo razlago, da bi uveljavitev odločbe informacijske 
pooblaščenke nepopravljivo škodila slovenski znanosti. S tem ko stapredvsem Turk $-v$ tem primeru presegla svoje zamere na račun dela ARRS, sta tudi zelo jasno pokazala prisotnim politikom, da znanstvena avtonomija ni nekaj, kar bi bilo mogoče razlagati po željah vsakokratne politične oblasti oziroma glede na simpatije do določene odgovorne osebe $v$ neki znanstveni instituciji.

Seveda tudi delo informacijske pooblaščenke presega nareke dnevne politike, kar je, brez dvoma, tudi že velikokrat dokazala. Vendar se lahko vsakdo še vedno česa nauči. V tem primeru specifičnosti ocenjevanja $v$ znanosti, ki mora biti, tako kot znanost sama, globalno opredeljeno. Resnično si je težko predstavljati ugled naše znanosti brez sodelovanja tujih recenzentov in z zelo omejenim sodelovanjem tistih domačih recenzentov, ki jih ne bi motilo popolno odkrivanje njihovih ocen.

Celo v primeru, da se ne bi - kar pa je v tem primeru gotovo nepredstavljivo - ozirali na tovrstno prakso $v$ drugih državah, bi ukinitev anonimnosti recenzentov $v$ znanosti gotovo poslabšala objektivnost ocenjevanja. Zakaj? Iz preprostega razloga, ker bi se v majhnem slovenskem znanstvenem prostoru, kjer se vsi dobro poznajo, komaj našli junaki, ki bi javno slabo ocenili projektne predloge kolegov. Domnevamo lahko, da bi to delo opravljali bodisi tisti maloštevilni, ki jim je vseeno, kaj drugi mislijo o njih, bodisi tisti, ki bi dajali same dobre ocene. To pa verjetno ni tisto, kar želimo naši znanosti. 



\section{Avtonomija}

Ozrimo se nekoliko nazaj, v leto 1088, ko je bila ustanovljena univerza v Bologni, ki je bila prva evropska univerza, v naslednjih stoletjih pa so ji sledile še Sorbona, Oxford, Cambridge ... Nastanek univerz je povezan z idejo vladarjev, da bi ustanovili institucijo, ki bi skrbela za predajanje znanja in najnovejših spoznanj novim generacijam, kar bi pospešilo razvoj in napredek države, ki bi zaradi tega lažje konkurirala sosednjim državam oziroma jih prekašala. Zanimivo je, da univerza ni bila zasnovana na temeljih, ki bi bili podobni temeljem diplomacije, kjer se odločilne stvari odvijajo $\mathrm{v}$ tajnosti, ali vojske, ki prav tako $\mathrm{v}$ tajnosti gradi svoj oborožitveni sistem, prav nasprotno, njeno izhodišče je bila odprtost. Univerza že v zasnovi vključuje pravico, da lahko profesorji prosto gostujejo na različnih univerzah in si izmenjujejo informacije. Raziskovalci so dobro vedeli, da je znanje obsojeno na počasnejši razvoj, če je ujeto med nacionalne meje.

Druga izjemna, lahko bi rekli osupljiva lastnost univerz je njihova avtonomija - še danes se večina čudi, zakaj je tako. Univerza je podobna Cerkvi: kdor se ji pridruži, mora upoštevati njene interne zakone, ki so nad zakoni zunanjega sveta. Nekoč je to veljalo dobesedno, sčasoma pa so zakone nadomestila nenapisana pravila. Za temeljne premike je namreč potrebna avtonomija, ki ščiti svobodo ustvarjanja - velikih idej ne smejo zaustavljati mali politiki, ki ne vidijo pet korakov naprej. Univerze so se vse bolj širile: konec srednjega veka jih je bilo v Evropi 30, konec 18. stoletja 150, danes jih je v 186 državah približno 18.500 (po podatkih World Higher Education Database, https://whed.net/home.php).

Da se znanost lahko nemoteno razvija, mora biti avtonomna v vseh elementih svojega delovanja. Zato ni naključje, da tudi financerji znanosti, raziskovalne agencije, postavljajo avtonomijo na vidno mesto. Avtonomnost raziskovalnih agencij je $\mathrm{v}$ razvitem svetu zagotovljena $\mathrm{z}$ neodvisnostjo njenih upravnih odborov, $\mathrm{v}$ katerih je po navadi samo en predstavnik države, pa še ta pogosto zgolj kot opazovalec.

Kakšna je situacija v Sloveniji? Seveda se morajo univerze povsod po 
svetu vedno znova boriti za svojo avtonomijo in pri nas ni nič drugače. Pomislimo samo na to, kako se je ljubljanski univerzi glede na menjavo režimov spreminjalo ime: Univerzi Kraljevine Srbov, Hrvatov in Slovencev v Ljubljani je sledila Univerza Kralja Aleksandra I. v Ljubljani pa R. Università di Lubiana in Universität Laibach, potem so jo preimenovali v Univerzo Edvarda Kardelja v Ljubljani in na koncu v Univerzo v Ljubljani. V sedemdesetih letih prejšnjega stoletja so bili pod partijskim pritiskom s Fakultete za sociologijo, politične vede in novinarstvo odstranjeni štirje profesorji, s Pravne fakultete v Ljubljani pa France Bučar. O tem, kako težko je uveljavljati avtonomijo, priča zapis Boštjana M. Zupančiča, ki se med drugim spominja določanja statusa Univerze v Ljubljani (Zupančič, 2015):

No, po osamosvojitvi je sledila precej bolj neprijetna prigoda, ko sem bil prorektor Univerze v Ljubljani, Bučar pa že predsednik skupščine. O mrtvih samo dobro, a takrat sem imel občutek, da je postal nekoliko avtoritaren. Pozabil je na čase, ko sva konspirativno prijateljevala. Opozoril sem ga, da novi krovni zakon o zavodih univerzi jemlje v ustavi zagotovljeno avtonomijo, da je smešno, da se Republika Slovenija proglaša za ustanoviteljico univerze, ko pa je res prav obratno.

Šlo je za to, da je bila univerza v samoupravnem socializmu dejansko javna neprofitna ustanova (public non-for-profit corporation), po novem pa bi postala navaden državni zavod. Bučar mi je odvrnil: "Ali ste zavod ali pa ste podjetje, tertium non datur (v sln. tretje ni mogoče).« Jaz pa: »Heh, če je to tako, je mar Katoliška cerkev zavod za čaščenje Boga ali je podjetje za pobiranje miloščine?«

Seveda pa se je pozneje izkazalo, da je bila izguba avtonomije za univerzo nekaj izrazito slabega; posledice se vidijo danes.

Razmišljanje Zupančiča torej seže še nekoliko dlje od avtonomije, $\mathrm{k}$ neodvisnosti. Toda ali je absolutna neodvisnost sploh možna? Če bi se malce pošalili, bi lahko rekli: celo Bog je odvisen od cerkev, saj se z njimi ohranja v zavesti in ravnanju ljudi.

Kljub temu je $\mathrm{v}$ slovenskem javnem sektorju avtonomija univerz $\mathrm{v}$ primerjavi z drugimi javnimi ustanovami največja (Svetlik, 2016). Tu imam seveda $\mathrm{v}$ mislih imenovanje rektorja, ki je $\mathrm{v}$ celoti prepuščeno sami univerzi. Zakon o visokem šolstvu namreč v 23. členu določa, da rektorja volijo vsi visokošolski učitelji, znanstveni delavci in visokošolski sodelavci, ki so na univerzi zaposleni, poleg njih pa še študentje, ki ima- 
jo eno petino glasov. Takšen sistem res zagotavlja avtonomijo, ne pa tudi dobre strokovne izbire, ki je sicer običajna na vseh uspešnih univerzah po svetu. Postopek bi gotovo lahko izboljšali, denimo že s tem, da bi rektorja volili redni profesorji, člani senata, kot je to veljalo nekoč.

Kaj pa znanstveni inštituti? Tudi imenovanje direktorja javnega raziskovalnega zavoda (inštituta) je dokaj neodvisno od politike. Temelji na Zakonu o zavodih (1991) in na Zakonu o raziskovalni in razvojni dejavnosti (2002), ki v 33. členu določa, da javni raziskovalni zavod in javni infrastrukturni zavod upravlja upravni odbor, v katerem so predstavniki ustanoviteljice, predstavniki zaposlenih in predstavniki uporabnikov oziroma zainteresirane javnosti. Upravni odbor ima od pet do devet članov. Število članov, ki mora biti liho, pri čemer nobena od treh strani v upravnem odboru ne sme imeti večine, in način njihovega imenovanja oziroma izvolitve se določita $\mathrm{z}$ aktom o ustanovitvi, podrobneje pa lahko še s statutom javnega zavoda. Vlada namreč na potek izbora lahko vpliva že s tem, ko daje vedeti, da bo potrdila le določenega kandidata, in tega se tudi poslužuje.

Kako pa je s politično neodvisnostjo financerjev znanosti? Zanimivo je, da bi nekatere zglede slovenske avtonomije javnih ustanov lahko našli v Skladu Borisa Kidriča in njegovi naslednici, R s s, ki sta bili ustanovi bivše skupne države. Njuno upravljanje je bilo politično dokaj neodvisno, poleg tega pa sta se zavedali pomena preglednosti svojega dela, kot lahko sklepamo po obveznosti, sprejeti že leta 1954, da se bo redno objavljalo letno poročilo o delu $\mathrm{z}$ vsemi podatki, potrebnimi za obveščenost javnosti, kar so tudi izvajali (Novak in Demšar, 2012). Po ustanovitvi slovenske države se je financiranje znanosti v celoti preneslo na državo, na ministrstvo za znanost, s čimer je politična neodvisnost v prvem obdobju slovenske samostojnosti nazadovala.

Eden od znakov nazadovanja je bila tudi možnost, da minister pri dodeljevanju sredstev v pritožbenem postopku sam odloči o izbiri desetih odstotkov dodeljenih sredstev, kar je prešlo tudi $\mathrm{v}$ utečeno prakso. $\mathrm{V}$ smislu političnih vplivov na dodeljevanje sredstev je zanimiva zgodba o slovenskem nakupu superračunalnika, naprave, ki je bila namenjena Institutu »Jožef Stefan« in je bila vredna toliko, kolikor so znašala celoletna sredstva za raziskovalno opremo na ministrstvu za znanost. Pogodba za nakup je bila podpisana leta 1994, dan pred združitvijo Liberalnodemokratske stranke z Demokratsko stranko, Socialistično stranko Slovenije in stranko Zelenih - ekološko socialno stranko $v$ današnjo Liberalno demokracijo Slovenije (L D S). Ker je bil v takratnem vodstvu Zele- 
nih - ekološko socialne stranke tudi Peter Tancig, sicer bivši in poznejši raziskovalec na IJ S, so se ob nakupu začela pojavljati domneve o preveliki povezanosti znanosti in politike.

Pomemben mejnik v politični neodvisnosti slovenske znanosti po slovenski osamosvojitvi je ustanovitev raziskovalne agencije leta 2004. Agencija je ob ustanovitvi sicer imela navidezno samostojnost, a pravo si je morala še izboriti. Lahko bi rekli, da se je s prizadevanji za neodvisnost raziskovalne agencije Slovenija šele zares začela izenačevati z drugimi članicami EU. Financiranje znanosti v Evropi namreč praktično povsod poteka prek raziskovalnih agencij. Tak sistem se je v Evropo razširil iz $Z \mathrm{DA}$, kjer so ga uvedli po drugi svetovni vojni. Podobno vlogo je imela sicer že RSS, le da njen sistem ni vključeval tekmovalnega načina financiranja, torej financiranja prek razpisov, ki je eden od pomembnih gradnikov sodobnih raziskovalnih agencij.

Slovenski znanstveniki, ki so sodelovali s kolegi po svetu, so bili seveda seznanjeni s tem, kako je znanost organizirana drugje. Poleg tega so, hkrati z znanstvenimi lobiji, verjetno spoznali, da prevelika povezanost politike in znanosti prinaša nestabilnost, zato so spodbudili ustanovitev znanstvene in tehnološke agencije, ki je nastala po finskem modelu. Vodenje agencije sem sam prevzel kmalu zatem in se najprej začel seznanjati s tem, kaj avtonomna agencija oziroma avtonomno financiranje znanosti sploh pomeni. Pri tem so mi veliko pomagali stiki $z$ drugimi evropskimi agencijami. V spominu mi je ostal pogovor z Ianom Smithom, predsednikom Evropske znanstvene fundacije, kamor se je A R R včlanila. Zadnje vprašanje, ki ga je predsednik fundacije pred včlanitvijo postavil, se je nanašalo na to, ali v Sloveniji o dodelitvi projektov odloča agencija ali minister. Ker je bil moj odgovor, da izključno agencija, glede vključitve ni bilo več nikakršnih dilem.

Med vodenjem agencije sem podrobno preučeval pogoje za avtonomijo agencije. Eden od njenih ključnih elementov je izbira direktorja. Je ta izbira politična ali nepolitična? Oziroma $\mathrm{z}$ drugimi besedami: so tisti, ki direktorja izbirajo, predstavniki politike ali predstavniki stroke? V večini evropskih agencij politika ne igra skorajda nikakršne vloge - v upravnem odboru ima zgolj opazovalca ali enega člana (Boh, 2006), večino pa sestavljajo predstavniki univerz in inštitutov. V Sloveniji je ureditev seveda povsem drugačna. Sčasoma sem si začel prizadevati, da bi sestavo upravnega odbora zakonsko spremenili in uvedli še nekaj s tem povezanih sprememb. Vendar sem pri svojih prizadevanjih naletel na vsakovrstna nasprotovanja. Leta 2014 smo v delovni skupini za do- 
polnitve zakona $\mathrm{v}$ zadnji verziji predloga pripravili vrsto potrebnih sprememb zakonodaje, vendar je Jernej Pikalo, tedanji minister za znanost, ki je spremembe sicer naročil, našim rešitvam nasprotoval, zatem pa je besedilo obležalo v predalih naslednjih ministric.

Avtonomija javnih ustanov je kazalec demokracije in zato zgodba, ki zadeva celotno družbo. Raven naše družbe s tega vidika šepa, saj bi težko rekli, da so naše javne ustanove avtonomne. Med njimi si svojega predstojnika same izbirajo le univerze, prevladujočega vpliva država prav tako nima pri izbiranju ravnatelja v osnovnih in srednjih šolah, a že pri inštitutih, kjer $\mathrm{v}$ upravnem odboru vlada sicer nima večine (v letih 2004-2006 jo je imela), je za odločitev upravnega odbora potrebno soglasje vlade. Vse druge javne ustanove - agencije, javni skladi, javni zavodi s področja kulture, zdravstva in šolstva - in tudi birokracija imajo avtonomije še manj, za razliko od razvitih demokracij, kjer je avtonomija javnega sektorja večja (Demšar in Zatler, 2018).

\section{Usodno združevanje}

Delo, 11. april 2012

Med vsemi raziskovalnimi inštituti v Sloveniji je Pedagoški inštitut (PI) prav gotovo med tistimi, ki so bili v svoji zgodovini največkrat na udaru politike. Že po naravi stvari je šolstvo eno tistih temeljnih družbenih področij, kjer hoče vsakokratna oblast s takšnimi ali drugačnimi ukrepi zagotoviti svojo izobraževalno vizijo. Po drugi strani pa je Pedagoški inštitut dolžan izobraževanju nastavljati kritično raziskovalno zrcalo, $v$ tem pa se nemalokrat, ne vedno v laskavi podobi, kaže tudi izobraževalna politika.

Eden od prvih ukrepov prve Janševe vlade na področju znanosti je bila sprememba sestave upravnih odborov (UO) javnih raziskovalnih zavodov (JRZ). V njih si je namreč vlada kot ustanoviteljica zagotovila obvezno večino in s tem premoč v odločanju.

Ena najrazvpitejših posledic te zakonske spremembe je doletela prav Pedagoški inštitut, ki je pred malo več kot šestimi leti s sklepom svojega upravnega odbora, ki ga je nato potrdila vlada, dobil novega vršilca dolžnosti direktorja, dr. Dejana Hozjana, prej zaposlenega na Ministrstvu za šolstvo in šport.

Velika večina zaposlenih v P I si je takrat želela, da bi jih še naprej vodil dotedanji direktor dr. Zoran Pavlovič, in razočaranje zaradi vsiljene vladne odločitve je bilo zelo veliko. Hozjan je končno odstopil, PI je do- 
bil direktorico, ki ga še vedno vodi, vmes je bila tudi umaknjena obvezna večina $v$ UO JRZ.

Prihod aktualne Janševe vlade pa je v Pedagoški inštitut prinesel ponovno vznemirjenje, ki mu tokrat po sklepu vlade v okviru varčevalne racionalizacije Ministrstva za izobraževanje, znanost, kulturo in šport (MIZK Ǩ̌) grozi pridružitev drugim javnim zavodom, ki se sicer prav tako ukvarjajo z izobraževanjem, vendar ima od vseh le PI status raziskovalne ustanove.

To pa ni obrobna, temveč bistvena značilnost. Kot raziskovalni inštitut je PI $v$ desetletjih navezal stike s sorodnimi tujimi institucijami, pridobival raziskovalne projekte in sprejemal mlade raziskovalce. Kot avtonomna znanstvena institucija je tudi dejansko neodvisen $v$ svojih raziskavah naše izobraževalne sfere in prav to je bila očitno tudi največja zamera resornih ministrstev dosedanjih vlad do dela Pedagoškega inštituta. V primeru združitve novonastala institucija niti ne bo več imela pogojev za raziskovalni status, kar bo pomenilo, da bo tudi P I oziroma to, kar bo od njega po združitvi ostalo, le še del strokovne podpore delovanja MIZKŠ.

Množica podpisov uglednih domačih intelektualcev in raziskovalcev iz tujih sorodnih raziskovalnih institucij pod peticijo proti ukinitvi PI verjetno ne bi smela ostati spregledana. Predvsem pa bi bila prva ukinitev kakšnega javnega raziskovalnega inštituta kaj slaba popotnica za menda razvojno ozaveščeno ekipo ministra Žige Turka in celotne vlade.

\section{Enakopravna obravnava vseh in enakopravnost spolov}

Enakopravna obravnava vseh ne pomeni zgolj omogočanja pravičnosti in enakopravnosti, ampak tudi boljše pogoje za razvoj, in nič drugače ni $\mathrm{v}$ znanosti. Uveljavljanje in dosledno uresničevanje načela enakopravne obravnave $\mathrm{v}$ znanosti spodbuja krepitev kakovostnih raziskovalnih kapacitet in s tem znanstvene odličnosti.

Po podatkih EU (European Commission, 2012) je med aktivnimi raziskovalci v E U $33 \%$ žensk, v Sloveniji pa $36 \%$. Med rednimi profesorji je bilo leta 2010 tako v E U kot v Sloveniji $20 \%$ žensk, $46 \%$ žensk pa Slovenija beleži pri podeljenih doktoratih, kar je prav tako enak odstotek kot v E U.

Nizek odstotek rednih profesoric in znanstvenih svetnic, ki imajo $\mathrm{v}$ akademski sferi najvišje plače, seveda pomeni nižjo povprečno plačo raziskovalk $\mathrm{v}$ primerjavi $\mathrm{z}$ raziskovalci. 
ARRS vse vloge obravnava po istih kriterijih, ne glede na akademski položaj prijavitelja, razlikuje le med mlajšimi in uveljavljenimi raziskovalci in upošteva razlike med znanstvenimi disciplinami, raziskovalkam pa se v primeru porodniškega dopusta financiranje za ta čas odsotnosti podaljša. Za spodbujanje enakopravnosti spolov je ARRS razvila vrsto mehanizmov, kar je v zunanji evalvaciji delovanja A R R S posebej pohvalila tudi fundacija E S F (European Science Foundation, 2011b). Normativni akti določajo, da mora biti med člani strokovnih teles in recenzenti vsaj tretjina predstavnikov enega od obeh spolov (to ne velja le za tehniške znanosti, kjer jih mora biti najmanj $20 \%$ ), kar AR RS uspešno izvaja tudi v praksi. V normativnih aktih je opredeljena tudi enakovredna vključenost invalidov $\mathrm{v}$ raziskovalno delo, ki določa, da se sredstva za posebne pripomočke, ki jih raziskovalec zaradi svoje invalidnosti pri delu morda potrebuje, štejejo kot upravičen strošek raziskovalnega projekta ali programa.

Načelno in pravnoformalno se zdi zastopanost obeh spolov v Sloveniji torej korektna, a praksa tega ne potrjuje v celoti. Tako, denimo, krepko šepa na dveh področjih, povezanih s slovensko znanostjo. Pri državnih nagradah za znanstvene dosežke je namreč med dobitniki najvišjih, Zoisovih nagradah zelo nizek delež žensk, enako pa velja tudi za članstvo V SAZU.

\section{Ženske prihajajo - mar res?}

Delo, 23. september 2004

Tisti, ki smo imeli nedavno priložnost, da v Talinu spremljamo sklepno konferenco ob zaključku dela tako imenovane izvedenske skupine Enwise, ki je po nalogu Evropske komisije preučila položaj žensk $v$ znanosti nekdanjih komunističnih držav srednje in vzhodne Evrope ter baltskih držav, smo pri tem gotovo delili vsaj en občutek - namreč zadoščenja, da je visoka evropska politika dejansko zmogla priznati, kolikšnega pomena je uravnotežena navzočnost žensk $v$ znanosti za skupni evropski razvoj.

Vendar ni šlo le za priznanje, da ženske v nobeni od navedenih držav pa tudi ne $v$ preostalih evropskih državah - kljub prevladujočemu deležu med diplomanti univerzitetnih študijev in v povprečju dokaj uravnoteženemu deležu med diplomanti podiplomskih študijev - ne zasedajo ustreznega deleža pomembnejših položajev $v$ znanstvenoraziskovalni sferi. Zgolj od takega spoznanja in priznanja bi bilo tudi le malo kori- 
sti. Veliko pomembnejše je bilo, da so tovrstne ugotovitve že doslej spremljale dejavnosti, ki naj bi izboljšale vlogo žensk v posameznih državah, pa tudi na ravni evropske znanosti in raziskav. V prihodnje naj bi tovrstno prizadevanje dejansko postalo ena od prednostnih nalog evropske raziskovalne politike in tudi politike posameznih držav.

Čeprav naj to ne bi bilo omejeno le na članice EU - na konferenco $v$ estonski prestolnici so prišle delegacije tistih držav, ki so letos pomladi postale članice Unije, tistih, ki so predvidene bodoče članice, in onih, ki se o tem članstvu še ne dogovarjajo -, ni nobenega dvoma, da bo Evropska komisija tovrstno politiko lahko dosledno zagotavljala le na območjih svojih pristojnosti, drugod pa bo že zagon teh dejavnosti povsem odvisen od razumevanja, ki ga bodo pokazali zanje odgovorni nacionalni politiki oziroma vodilni v nacionalnih raziskovalnih ustanovah.

Pri tem je pomembno vedeti še nekaj. Evropska komisija se je odločila, da razmere - potem ko je pred nekaj leti dobila podobo o vlogi žensk $v$ znanosti $v$ članicah Unije in takratnih kandidatkah - podrobno preveri prav v nekdanjih komunističnih državah, to pa nikakor ni bilo naključje. Dejstvo je, da je delež žensk v znanosti v omenjenem krogu držav precej ugodnejši kakor v državah, ki jih komunizem v preteklosti ni obremenjeval. Tokrat se je verjetno sploh prvikrat - seveda dopuščam možnost zmote - zgodilo, da je v nekem poročilu, ki ga je naročila in plačala Evropska komisija, zapisano, da je imela komunistična politika tudi pozitiven učinek, $v$ tem primeru $v$ precej večji enakopravnosti žensk pri zasedanju položajev $v$ znanosti, kolikor je ima večina drugih evropskih držav; morda je izjema le Finska.

Ne glede na vzroke, ki so k temu pripomogli - večji delež žensk v znanosti ni spodbujala le večja enakopravnost, temveč predvsem eksistenčna nuja -, je ta trenutek to tista prednost, ki bi jo morale države, ki jo imajo, ohraniti in še bolj spodbuditi. Zato je bil projekt Enwise narejen $v$ pravem oziroma dejansko zadnjem še primernem trenutku. Zdaj pa bo treba počakati, kaj mu bo sledilo, poleg že izvajanih ukrepov pomoči tistim raziskovalkam, ki jim je snovanje družin začasno prekinilo kariero, poleg dokaj učinkovitih ukrepov za povečanje deleža žensk med ocenjevalci evropskih raziskovalnih projektov in poleg načrtovanih regionalnih evropskih centrov za spodbujanje ustrezne vloge žensk v znanostiza zdaj je predviden le prvi tak center, ki bo pokrival »območje Enwise» in bo imel sedež v Pragi.

A usoda tega centra in celotnega projekta za spodbujanje vključevanja žensk $v$ evropsko znanost in raziskave bo zdaj tudi precej odvisna od 
tega, kako se bo do teh vprašanj opredelilo novo vodstvo Evropske komisije. Ne glede na ves dosedanji trud in razmeroma veliko evropskega denarja, že porabljenega v ta namen, je namreč učinek še vedno mogoče tako rekoč izničiti, če bi se tistim, ki odločajo o raziskovalni politiki, to, kako so ženske »uporabljene« $v$ znanosti, morda zazdelo nepomembno, zgolj feministično vprašanje...

Da ta možnost ni zgolj hipotetična, kaže med drugim zelo skromna udeležba vidnejših političnih predstavnikov $v$ delegacijah, zbranih na talinski konferenci. Le gostiteljica Estonija, katere predsednica parlamenta Ene Ergma je tudi vodila izvedensko skupino Enwise, je prepričljivo dokazovala, da je to zanjo dejansko ena od prednostnih političnih usmeritev - seveda je zdaj od tega cilja še neprimerno dlje, kakor je, denimo, Slovenija. Vendar utegne Estonija $z$ doslednim upoštevanjem načel, da naj bo izkoristek žensk $v$ znanosti skladen $z$ njihovimi $z$ diplomami dokazanimi sposobnostmi in da mora to veljati na vseh ravneh, torej tudi pri delitvi najodgovornejših funkcij, sčasoma prehiteti vse konkurentke.

Velike rezerve dobro izobraženih žensk so morda zadnja res velika neizkoriščena prednost. Ne le vsej Evropi, temveč vsaki evropski državi, ki se bo tega zadosti zavedela, se verjetno obeta precej hitrejši razvoj, kakor bi ga imela sicer.

Bo v tem krogu tudi Slovenija? Njeno zavzeto sodelovanje v projektu - v Talinu je imela naša država eno najštevilčnejših delegacij, a v njej ni bilo niti enega moškega, kaj šele koga od naših politikov - že lahko zbuja takšno upanje, a slovenska politika doslej, žal, ni pokazala posebne zavzetosti. Sicer pa - ste morda v tem predvolilnem času slišali, da bi katera od strank to temo uvrstila $v$ zbirko volilnih obljub?

\section{Etični standardi in poštenost}

Za znanstveno dejavnost in za zaupanje družbe $\mathrm{v}$ znanost je zelo pomemben odgovoren odnos do raziskovanja. Toda tako kot drugje, tudi v znanosti prihaja do neetičnih ravnanj, motivacija zanje pa je običajno osebno okoriščanje, ki k razvoju znanosti nič kaj ne prispeva.

Do prevar pri objavljanju znanstvenih člankov je na primer prihajalo že skoraj na samem začetku, denimo v Toyardovem članku iz leta 1679 o tem, da človek lahko leti podobno kot ptič. Posebno kategorijo prevar predstavljajo vzporedna odkritja, torej odkritja, ki so jih razglašali za nova, a to niso bila, pri čemer avtor tega bodisi ni vedel ali pa je to 
zamolčal. Sociolog Robert K. Merton je ugotovil, da je bilo v 17. stoletju zabeleženih kar $92 \%$ vzporednih odkritij, v 18. stoletju je delež padel na $72 \%, v 19$. stoletju na $59 \%$ in v prvi polovici 2o. stoletja na $33 \%$ (Merton, 1938).

Raziskovalci in raziskovalne organizacije so sami odgovorni za to, koliko se načela poštenosti in mednarodno sprejeti etični standardi upoštevajo pri raziskovanju. Univerze, združenja raziskovalcev, akademije, agencije pri tem sprejemajo raznovrstne ukrepe za preprečevanje neetičnih ravnanj, običajno so to kodeksi, pogosto pa tudi postopki, ki obravnavajo kršitelje. Univerze in inštituti lahko ukrepajo tudi s prekinitvijo delovnega razmerja - taki primeri so žal znani tudi pri nas -, med ukrepi tujih raziskovalnih agencij je večletna prepoved prijavljanja raziskovalnih projektov spornih avtorjev, pri znanstvenih revijah pa uvrstitev spornih avtorjev na črno listo.

Menim, da bi bilo smiselno sprejeti kodeks poštenosti v raziskovanju in ustrezno zakonodajo, ki bi za kršitelje kodeksa predvidela sankcije. Da bi se pri tem izognili morebitnemu konfliktu interesov, bi morali pri presojanju sodelovati tudi tuji strokovnjaki.

\section{Pod žarometom: akademik Jože Toporišič}

Delo, 28. november 2006

Letošnji dobitnik Zoisove nagrade za življenjsko delo, akademik doktor Jože Toporišič, ki je 11. oktobra dopolnil 8o let, se je rodil v kmečki družini na Mostecu pri Brežicah. Študentom je med začetnimi predavanji rad povedal, da mu pravilna izreka slovenščine ni bila dana $v$ zibko.

$\mathrm{Na}$ študij slovenistike in ruščine na filozofski fakulteti (F F) ljubljanske univerze se je vpisal po klasični gimnaziji v Mariboru. Leta 1963 je na F F doktoriral, tema doktorata je bila nazorska in oblikovna struktura Finžgarjeve proze. Od leta 1954 do 1965 je bil lektor slovenskega jezika na zagrebški univerzi, nato pa je predaval na FF, kjer se je leta 1997 upokojil - tega leta je postal redni član SAZU.

Dejstvo je, da akademik za svoje delo ni bil deležen zgolj pohval. Slovenci smo zelo občutljivi na vsak poseg $v$ naš materni jezik in $v$ tem je verjetno razlog, da so Toporišiču mnogi oporekali njegove nenavadne besedne tvorbe.

Toda seveda mu nihče nikdar ni oporekal, da je v slovenski slovnici in knjižnem jeziku opravil delo kot pred njim malokdo. Med drugim je uveljavil sodobno izgovorjavo, strukturno jezikoslovje, pravopisje in 
besedotvorje. Napisal je približno 30 knjig in številne jezikoslovne razprave. Njegova osebna bibliografija obsega več kakor 1.200 enot, med katerimi je vsaj 70 avtorskih in uredniških monografskih del. Njegova akademska slovnica, ki je po prvi izdaji leta 1976 doživela več razširjenih in dopolnjenih izdaj, sodi med temeljna dela slovenskega jezikoslovja 20. stoletja. Njegova pomembna dela so še Glasovna in naglasna podoba slovenskega jezika, Nova slovenska skladnja, Portreti, razgledi in presoje, Družbenost slovenskega jezika, Besedjeslovne razprave in številne druge razprave.

Glede na tako obsežno delo je bil doslej deležen presenetljivo malo nagrad - pred 29 leti je dobil nagrado graške univerze, pred 27 leti pa nagrado Kidričevega sklada in nagrado Mednarodnega društva za fonetične vede. Letošnja državna nagrada torej popravlja tudi to krivico. Kot piše v obrazložitvi Zoisove nagrade, je akademik Toporišič pomembno zaznamoval slovenski strokovni in širši kulturni prostor druge polovice 20. stoletja. Metodološke prvine njegove slovnice so skupaj s strukturalno zasnovo njegovega Slovarja slovenskega knjižnega jezika vplivale na evropsko aktualno preureditev slovenskega jezikoslovnega nazora. Vprašanja sodobne slovenščine, zlasti aktualnega knjižnega jezika, pa so z njegovim znanstvenim delom postajala nepogrešljivi del vrednostne podobe slovenstva.

\section{Slovenski jezik}

Raba slovenskega jezika $\mathrm{v}$ znanosti je pomemben del problematike slovenske identitete. Zdravko Mlinar v svoji obsežni monografiji uporabo nacionalnih jezikov uvrsti med pomembna vprašanja, povezana $z$ globalizacijo (Mlinar, 2012). Procesi globalizacije se najprej odrazijo v znanosti in nanjo tudi najvidneje vplivajo. Znanost pa je ne nazadnje zares lahko uspešna šele takrat, ko njena dognanja postanejo splošno dostopna, torej "globalna«. Znanstveno objavljanje zato stremi k temu, da bi vsak lahko bral besedila in jih pri svojem raziskovanju upošteval. Posledica tega je tudi dejstvo, da so danes praktično vsa znanstvena dela objavljena v angleškem jeziku.

Preglednica 8.1 na naslednji strani ponazarja primerjavo med maternim jezikom objavljanja na Finskem in v Sloveniji, v dveh majhnih državah, obkroženih $z$ velikimi narodi. Primerjava Slovenije s Finsko je ustrezna tudi zato, ker finska univerzitetna baza Kota nudi številne enakovrstne podatke kot slovenska baza С О B IS s. Leta 1992 smo v Slo- 
Preglednica 8.1 Jezik objavljanja po vedah (delež objav v maternem jeziku) primerjava Slovenije in Finske

\begin{tabular}{lrrr}
\hline Veda & Slovenija & Slovenija & Finska \\
& 1992 & 2014 & 2005 \\
\hline Naravoslovje & 12 & 8 & 13 \\
Tehnika & 41 & 12 & 17 \\
Medicina & 28 & 33 & 22 \\
Biotehnika & 60 & 20 & 24 \\
Družboslovje & 81 & 40 & 52 \\
Humanistika & 73 & 58 & 64 \\
\hline
\end{tabular}

OPOMB E V odstotkih. Povzeto po Sorčan, Demšar in Valenci (2009) in po podatkih Sicrisa (http://www.sicris.si).

veniji v primerjavi s Finsko imeli bistveno večji odstotek znanstvenih objav v maternem jeziku na področjih tehnike, biotehnike, družboslovja in humanistike, v naravoslovju in medicini pa smo bili primerljivi. Danes je vzorec objavljanja primerljiv na vseh področjih. V obeh državah prevladujejo objave $\mathrm{v}$ angleškem jeziku, razen pri družboslovju in humanistiki, kjer je delež objav v domačem jeziku krepko nad polovico.

Premik, ki se je v Sloveniji zgodil na področju jeziku objavljanja, je posledica internacionalizacije slovenske znanosti, njene umestitve v svetovno izmenjavo znanja. Kaj naj potemtakem storijo slovenske znanstvene revije? Tiste, ki ne dosegajo mednarodnih standardov, po katerih se uvrščajo v bazi wo S ali Scopus, bi se morale preoblikovati v strokovne revije, država bi jih morala pri tem podpreti, univerze in inštituti pa bi morali slovensko strokovno publiciranje vgraditi v habilitacijske postopke. Slovenski znanstveni članki bi morali posebno pozornost namenjati predvsem slovenski znanstveni terminologiji in preglednim strokovnim člankom. Prav te usmeritve so bile na predlog A R RS vključene v dokument, ki je leta 2014 opredelil strategije uporabe slovenskega jezika (»Resolucija o Nacionalnem programu za jezikovno politiko 20142018«, 2013).

Slovenija pa bi morala po drugi strani spodbujati tudi prevajanje in objavljanje znanstvenih monografij domačih avtorjev pri uglednih mednarodnih znanstvenih založbah. S področja humanistike in družboslovja so $v$ slovenskem jeziku objavljena številna odlična znanstvena dela in velika škoda je, da nekatera od teh niso prevedena $\mathrm{v}$ angleščino, saj bi lahko obogatila svetovno izmenjavo znanja. AR RS je leta 2013 skupaj z Mladinsko knjigo prav zaradi tega in za dodatno spodbudo našim razi- 
skovalcem ustanovila spletno znanstveno založbo, vendar je žal začasno zamrla.

Problematika uporabe slovenskega jezika je seveda veliko zapletenejša, kot se kaže zgolj s tehnicistične perspektive, s katere smo jo načeli v tem kratkem poglavju. Njen spekter se razteza od popolne brezbrižnosti do mnenja, da smo s tem, ko smo to vprašanje povsem obšli, ne le sprožili plaz, ampak nas je plaz pod seboj že pokopal.

\section{Kriza temeljnih vrednot}

Izhod iz etične krize, ki morda korenini v točkastih genetskih mutacijah

Delo, 14. januar 2012

"Strinjam se, da sta svetovna in še posebej slovenska družba v krizi temeljnih vrednot in da jima ob tem primanjkuje motivacije. Prevladujeta strah za prihodnost in egoistični refleks grabljenja k sebi, saj zmotno menimo, da nam bo to prineslo večjo varnost. Kriza se pojavlja tudi v družini, saj starši težko motivirajo sedanje generacije enako, kakor so bili motivirani oni. Vrednota zgolj denarja in uspeha za vsako ceno je povsod prisotna. Zmagovalec je le eden, vsi drugi pa so po taki analogiji poraženci.«

Ali uvodno izjavo pripisujete komu od naših družbenih analitikov? $N e$, očitno $v$ današnjem času temeljna družbena vprašanja vse bolj vznemirjajo tudi naravoslovce, da so se vsaj nekatera od njih - biološki izvor družbenih izkrivljenosti - trdno zasidrala $v$ sodobnih znanostih o življenju. Navedba je del odgovora našega uglednega biotehnologa, prof. dr. Miomirja Kneževića, pomočnika direktorice Nacionalnega inštituta za biologijo, na vprašanje, ali se s strinja s tistimi, ki opozarjajo na velik primanjkljaj znanja in vrednotenja, povezanega z etičnimi odločitvami in moralnimi presojami $v$ današnji slovenski družbi. Po Kneževićevem mnenju je slovenska družba s tem, ko je v preteklih dveh desetletjih izpolnila večino konkretnih ciljev - osamosvojitev, vstop v EU in NATO, prevzem evra-, vzbudila lažni občutek, da smo »na varnem《. Zdaj ko je jasno, da ni tako, pa nam »manjka strateško razmišljanje, ne spoštujemo drugega mnenja in globoko v sebi čutimo, da tudi sebe ne spoštujemo«. V iskanju izhoda iz te stiske, pravi, bolj zaupamo misti$k i$ in vraževerju kakor znanju, treznemu razmisleku in svojim etičnim vrednotam. »Raj za špekulante, lažne preroke ... To se je v zgodovini že večkrat zgodilo. Prevrednotenje vrednot. To nas spet čaka." 


\section{$V$ nas je genetska nagnjenost $k$ neracionalnemu pohlepu}

$V$ začetku lanskega decembra - tako blizu je ta čas, a z današnje perspektive se nam zdi verjetno precej brezskrbnejši - je bila ob tednu ljubljanske univerze (UL) slavnostna seja senata $U L$ in tedaj je bil slavnostni govornik predsednik SAZU, akad. prof. dr. Jože Trontelj.

Preden je spregovoril o nalogah akademije in univerz $v$ času globalne krize, je predstavil pogled sodobnih genetikov na dogodke $v$ daljni preteklosti. Mogoče je sklepati, da se je kal današnje krize pred kakimi 50.000 leti zapisala $v$ človeški genom, morda zaradi treh točkastih mutacij v genu FOXP 2 naših prednikov, ki so živeli v Afriki in njihova kultura "ni bila dosti višja od kulture antropoidnih opic«. Nato pa so omenjene mutacije sprožile »kaskado nevroloških in kognitivnih sprememb «, med njimi »najbrž razvoj govora, mogoče tudi sposobnost abstraktnega mišljenja, razumevanje preteklosti, predvidevanje prihodnosti, smiselno načrtovanje«. Vistem genomu pa je bila zasidrana tudi "potreba po moralnih vrednotah, kot so pravičnost, poštenje, dobrohotnost, ljubezen do bližnjega, potreba po spoštovanju svetega« ... Slaba stran pa je bila, da je bila med novimi, z genetskimi mutacijami sproženimi spremembami tudi »dedna nagnjenost k neracionalnemu pohlepu in agresivni tekmovalnosti«.

Tako smo torej že davno dobili vse hkrati - tiste lastnosti, ki človeško raso kar naprej potiskajo v krize, ter sposobnost moralne presoje in etičnega samoomejevanja. Prvi med akademiki je v omenjenem slavnostnem trenutku univerzitetno javnost opozoril, da so današnje razmere $v$ svetu $v$ doslej največjem primežu te človeške dvojnosti, da dobri del mutiranega genoma vse bolj popušča pred slabim. Razložil je, da to globalno dokazuje tudi naš odnos do okoljskih problemov, do okrutnih vojn in lakote, brutalnega izkoriščanja otrok, trgovine s človeškimi organi, ki je po obsegu že prehitela trgovino z mamili ...

Izhod iz samomorilske zanke človeštva omogoča navidezen paradoks dedne lastnosti, ki je hkrati stoodstotno odvisen od genetskega zapisa in prav toliko od vzgoje in osebne izbire. Za etične odločitve in moralno neoporečno vedenje, je v svojem govoru rekel akademik, potrebujemo ne samo zrele, temveč tudi resnično svobodne ljudi, ki ne bodo materialisti in bodo zato tudi veliko srečnejši. Do take svobode pa bi lahko prišli z ustrezno vzgojo, utemeljeno na etičnih načelih, ki bi segala od vrtcev do univerz. Takrat je Trontelj pozval univerzo, da pri tem prevzame svoj del naloge.

Ko se z akademikom o tem pogovarjam dva meseca kasneje, je to, 
kar se je v govoru zdelo šele zametek strategije načrtovanja rešitev iz etične krize, videti že veliko otipljivejša resničnost. Kaže se pot, kako se bomo lotili pomanjkanja vrednot in slabega razlikovanja med moralnim in nemoralnim ravnanjem, skrb zbujajočih pojavov naše dobe.

\section{Zlate dobe nikoli ni bilo, se ji pa želimo vsaj približati}

Dr. Trontlja, mednarodno uglednega strokovnjaka za bioetiko, ki o tovrstnih vprašanjih razmišlja na nacionalni in evropski ravni, sem izzvala $z$ vprašanjema, ali se mu zdi, da je kdaj v kakšni družbi obstajala vsaj približna skladnost med etiko, moralo in pravom, ter ali si je kakšna država sploh želela takšno, za vladanje verjetno precej naporno skladnost. "To je bil že starodavni ideal mislecev in pesnikov, kar dokazujejo briljantne misli grških filozofov, med antičnimi pesnitvami pa Ovidijeve Metamorfoze, ki se začenjajo z zlato dobo, $v$ kateri je človeštvo spoštovalo poštenje in pravico brez zakonov in prisile. Mislim pa, da te zlate dobe nikoli ni bilo. Ostane nam le upanje, da bomo lahko z razvojem človeške družbe zmanjšali grožnjo kazni, ko bo zanjo vse manj potrebe. A za to bomo potrebovali drugačno lestvico vrednot. Namesto želje po materialnem bogastvu bo morala postati vrednota zavest, da ni treba imeti tistega, česar $v$ resnici ne potrebujemo. Vrednota bo prizadevanje, da človek dozori kot oseba, da razvije svoje talente in sposobnosti, a brez tuhtanja, kakšno prednost si bo s tem pridobil pred drugimi. Sodobne raziskave kažejo, da je raven zadovoljstva družbe, sreče državljanov, obratno sorazmerna $\mathrm{z}$ velikostjo razlik med bogatimi in revnimi. To nam veliko pove. Vendar še premalo, da bi si človeštvo že danes kot prednostno smer razvoja izbralo doseganje ciljev nematerialne blaginje."

Sodobni razvoj tehnologije postavlja tudi nove etične dileme. »Teh je cela vrsta, a vzemimo zgolj eno. S sodobno informacijsko tehnologijo bi lahko že danes bolj učinkovito omejili kriminal, a s tem bi pretirano posegli $v$ človeško svobodo. Večini ljudi se zdi bolje, da žrtvujemo del svoje varnosti, kot da bi žrtvovali svojo svobodo in zasebnost. Zdi pa se, da bo nadzor kmalu postal tako vseobsežen, da te izbire in s tem prave svobode in zasebnosti preprosto ne bo več."

Seveda smo akad. Trontlja vprašali tudi o etičnih dilemah, ki jih vzbuja naša aktualna politična stvarnost. »V zadnjih desetletjih nam je uspelo pripeljati etiko v znanost. Danes imamo v znanosti dobro delujoč etični nadzor. To je zelo spodbudno. Morda bo sčasoma kaj podobnega uspelo tudi v politiki. Vse več je politikov, ki razumejo, da je prav v tem prihodnost.« 
Ǐčimo tiste, ki so pokazali, kako se zmaga

Zdaj so se akademiki lotili vračanja etičnih vrednot. »Akademije v Evropi in po svetu delujemo povezano in ideja, da je treba mladim v današnji družbi znova približati prave vrednote, je naša skupna. Vsi opažamo, da imajo današnje mlade generacije več informacij, vendar kljub temu manj znanstveni pogled na svet. Večini mladih resnične vrednote ne pomenijo veliko, neoliberalno okolje pa tudi ne vpliva spodbudno nanje. Razmer za zdaj ne moremo spremeniti, kaj pa lahko naredimo? Akademije soglašajo, da je etično preobrazbo mogoče narediti prek vzgoje in izobraževanja, in to na vseh ravneh, od vrtcev do univerz, z doktorskim študijem vred. Mislim, da to ljudje pričakujejo od akademikov, še posebej v tem težkem času.

S temi idejami smo pri nas povsod naleteli na odličen odziv, tudi v vrtcih. Zato imamo zdaj serijo posvetov o znanju kot vrednoti, o privzgoji spoštovanja do znanosti pa tudi o načinih, kako pomagati mladim do odličnega, neoporečnega znanja. Skrbno poslušamo izkušene učitelje in profesorje, njihova sporočila pa bomo posredovali šolskim oblastem in ministrstvu. Osebno me najbolj veseli, da naših vzgojiteljic, učiteljev in profesorjev ni treba prav nič prepričevati o pomenu etične vzgoje. Vsi so za to, mnogi komaj čakajo. Vesel sem tudi tega, da k projektu pomembno prispeva Zavod Žige Zoisa kot ustanova civilne družbe."

Tudi uvodoma omenjeni dr. Knežević ponuja zdravilo za krizo vrednot, in sicer takšno, ki je kot »trpka pilula s stranskimi učinki«. Meni, da bi se morali odreči pretiranemu egu, se začutiti kot del skupnosti na celini s pol milijarde prebivalcev. A ob tem tako kot akad. Trontelj tudi $d r$. Knežević ugotavlja: »Največ znanja in temeljnih vrednot pridobimo $v$ družbi in šoli - na vseh ravneh. $Z$ zgledi, res samo z zgledi, morajo avtoritete pokazati, da združeni zmoremo več. To sicer piše v knjigah, toda obnašamo se drugače - zaradi egoističnega strahu, ki nam hromi možgane in dreveni telo ... Začnimo spet kazati dobre zgodbe, ki jih ne manjka, ne iščimo krivcev za poraze, iščimo tiste, ki so pokazali, kako se zmaga. To vlije voljo, ki jo sedanja mlada generacija potrebuje, saj je jezna, ker meni, da smo ji vzeli prihodnost. Zaradi našega egoizma." 


\section{Pogled v prihodnost}

Mogoče bo kdo pomislil, da prihodnost ne spada v knjigo, ki se ves čas ozira v preteklost, predvsem $\mathrm{v}$ zadnje četrtstoletje, pa vendar je je bilo zame prav to bistveno. Ob analizi podatkov sem se namreč ves čas spraševal, zakaj so kazalci taki, kot so, kaj vpliva na rezultate, kaj je pripeljalo do uspehov, kateri so razlogi za neuspehe - kaj bi torej lahko v bodoče izboljšali in čemu se izognili.

\section{Bi morala znanost iz E U?}

Delo, 26. april 2018

Komaj nekaj dni po letošnjem drugem shodu za znanost, ki je potekal pod geslom "Zakaj ne za znanost?", je problem znanstvenoraziskovalne sfere, ki životari z manj kot pol odstotka BDP, že skoraj pozabljen. Zasenčili so ga predvolilni shodi, kjer pa bo znanost zelo verjetno komaj kdaj omenjena. Razen leporečno, brez konkretnih zagotovil za sprejem pripravljenega zakona, zagotovitve finančne rasti itd. Zakaj bi bilo tokrat drugače, kot je pri nas že dolga leta?

V tem desetletju se je zvrstilo že kar nekaj vlad in prav vse so po mačehovsko obravnavale znanost. Najbolj »inovativen « vladni ukrep je bil, leta 2012, ko je vlada povečala samo visokošslski proračun in napovedala, da bo znanost prišla na vrsto dve leti kasneje. A to se, seveda, $v$ resnici ni zgodilo. Dobila je zgolj drobtinice.

Slišati je, da bodo letošnje parlamentarne volitve zelo dolgočasne zaradi preveč podobnih strankarskih programov. Drznimo si torej predlagati, kako bi lahko kandidati pomagali sebi in znanosti. Najprej bi moralo biti vsem politikom jasno, zakaj se jim podpora znanosti $v$ vsakem primeru splača. Nato bi jim koristila vsem volivcem razumljiva razvojna strategija, saj v znanosti ni mogoče slepomišiti.

Ali veste, da imajo $v$ Veliki Britaniji ministrstvo za univerze, znanost, raziskave in inovacije? Zakaj to omenjamo? Zato, ker je to ministrstvo 
izjemno uspešno $v$ podpori vseh omenjenih sfer, kar se je nazorno pokazalo $v$ težkem obdobju po britanski odločitvi za izstop iz EU. Vlada je svoji raziskovalni in akademski sferi zagotovila, da bodo raziskovalci od svoje države dobili povrnjeno vse, kar jim bo po letu 2020 morda zmanjkalo iz Okvirnih programov E U, kjer so bili vsa leta zelo uspešni.

Ob enotni podpori, ki jo britanska znanost dobiva od celotne vlade, $z$ vidno vlogo premierke, morda ime ministrstva niti nima takšne vloge, kot bi jo lahko imelo sicer. Nekateri se gotovo spomnite, da smo tudi pri nas po osamosvojitvi imeli najprej ministrstvo za znanost in tehnologijo, nato se je k temu priključil še visokošolski sektor, tehnologija pa se je odselila $v$ gospodarstvo. Toda večje težave s financiranjem znanosti so se pojavile šele, ko sta se na to ministrstvo obesila celotna šolska sfera in šport.

Dejansko se je takrat raziskovalce $v$ polnem pomenu besede začelo obravnavati kot javne uslužbence, raziskovalno sfero pa kot del javne porabe. S takšnim zornim kotom znanost pač ne more postati zelo učinkovito gonilo našega družbenega napredka. Uspešnost, ki jo vendar dosega, je v veliki meri zasluga evropskega denarja, v Evropo in še kam pa odteka tudi večina pri nas pridelanega znanja.

Zato naslovno vprašanje ni sarkazem. Če bi Slovenci na referendumu sprejeli odločitev o odhodu iz EU, bi nas Bruselj odpisal še veliko hitreje in temeljiteje, kot je svojo ustanovno članico. Takrat bi naša vlada morala sprejeti strateške ukrepe in med temi bi nemara bila tudi močna podpora znanosti in inovacijam. Le ogroženo preživetje bi morda za znanost slepim odprlo oči.

\section{Strategije}

Med pisanjem knjige sem se pogovarjal z Erikom Vrenkom, ki mi je razložil svoj pogled na začetke projekta mladih raziskovalcev. Leta 1982 je v vlogi republiškega sekretarja (sedanji minister) republiškemu izvršnemu svetu (vladi) predložil dokument Strategija Slovenije. Danes, v poplavi strategij vseh vrst, bi zamahnili z roko, takrat pa je bil to odmik od prakse planskih dokumentov. Vrenkova argumentacija je v Strategiji izhajala iz ocene, da Slovenija letno zavrže približno 500 najobetavnejših ljudi, ključnih za njen razvoj. Da bi kar najbolje pripravil temelje programa, ki bi najobetavnejšim 500 študentom zagotovil nekajletno plačo in raziskovalna sredstva za kakovosten doktorat, je zaposlil Cirila Baškoviča, enega izmed vodij študentskih demonstracij v sedemdesetih letih. 
Skupaj sta spodbudila sodelovanje med stroko v Rs S (Robert Blinc) in SAZU (Aleksander Bajd) ter politiko, ki je pobudi prisluhnila tudi po zaslugi Borisa Frleca, sicer direktorja IJ S, od leta 1984 pa podpredsednika vlade. Že leta 1985 se je proračun za znanost podvojil in s tem dosegel najvišjo vrednost v naši zgodovini. Deset let so bila slovenska proračunska sredstva za znanost tako vendarle primerljiva $\mathrm{z}$ evropskimi vlaganji (slika 3.3 na strani 47). Vsi kasnejši snovalci znanstvenoraziskovalne politike so sledili temu zgledu - vlaganja v znanost ne dajejo kratkoročnih rezultatov, zato jih je treba dobro strateško utemeljiti. Leta 1990, na začetku mandata ministra Tanciga, nastane »bela knjiga" (Alkalaj in Baškovič, 1990), ki je pomen znanosti strateško utemeljila v novih razmerah. V parlamentu so zatem sprejeli tri uradne dokumente o pomenu in vlogi raziskav in razvoja v Sloveniji - N R P, N R R P in RIS S -, a nobeden od njih ni imel takega učinka kot Strategija Slovenije iz leta 1982. Zakaj? Za to obstaja več razlogov.

Prva strategija si je privoščila bistveno več ambicioznosti kot naslednje, saj je ustvarjanje spodbudnih pogojev za našo intelektualno elito postavila v samo srčico nacionalne strategije, vsi kasnejši dokumenti pa so dobili status zgolj področnih strategij. Mogoče je prav zdaj priložnost, da se to spremeni in znanje spet postane prva strateška prioriteta države. Od leta 2013, ko je potekla veljavnost Strategije razvoja Slovenije, Slovenija namreč nima osnovnega strateškega dokumenta. Parlament je sicer sprejel vrsto področnih strategij, vendar o hierarhiji ciljev ne moremo govoriti, saj krovna strategija ne obstaja. Področne strategije so poleg tega zasnovane tako, da ne omogočajo prilagajanja spremembam in da niso dovolj proračunsko zavezujoče.

Uspešen model, ki ga uporabljajo v ZDA, so strategije s premičnim časovnim okvirom: parlament sprejme, recimo, desetletno strategijo 2015-2025, to nato na sredini izvajanja, po petih letih, temeljito analizirajo ter dopolnijo in ponovno sprejmejo $\mathrm{v}$ parlamentu za naslednjih deset let (2020-2030). To se ponovi vsakih nadaljnjih pet let, lahko pa, če je potrebno - ob hitrih spremembah okoliščin ali ob nastopu nove vlade - tudi prej. S tem se izpopolnjuje tako dolgoročno načrtovanje kot prilagajanje aktualnim razmeram. Da bi bil tak pristop ustrezen, lahko vidimo pri primeru raziskovalno-inovacijske strategije Slovenije (»Resolucija o raziskovalni in inovacijski strategiji Slovenije 2011-2020«, 2011). Raziskovalno-inovacijska strategija je bila v času, ko so jo sprejeli, dobro zastavljen dokument. Usmeritev prejšnjega strateškega dokumenta je nadaljevala, hkrati pa jo je umestila v širša evropska razmišljanja. Ven- 
dar če dokument, ki je nastal tik pred finančno krizo, pogledamo danes, hitro ugotovimo, da postavlja neuresničljive cilje in ne odgovarja na dileme, v katerih se je Slovenija znašla v času krize. V njem na primer piše, da se bodo vlaganja $v$ R R do leta 2020 povečala na 3,5 odstotka B D P, toda namesto da bi se temu cilju približali, smo se zaradi finančne krize od njega oddaljili. Brez dvoma bo treba že kmalu začeti razmišljati o Sloveniji po finančni krizi, o vlogi raziskav in razvoja v novem obdobju, o novih instrumentih za učinkovita vlaganja v R R. Podoben primer je, denimo, tudi strategija ekonomskih migracij (»Strategija ekonomskih migracij za obdobje od 2010 do 2020 «, 2010), ki je bila sestavljena precej pred migracijskim valom, in ko je do povečanih migracij prišlo, se sestavljavcem ni zdelo vredno, da bi jo dopolnili. Takih primerov strateških dokumentov, ki niso usklajeni z dejanskimi razmerami in novimi okoliščinami, bi našli še precej.

Države, ki resno jemljejo strateške dokumente (recimo Švedska, Južna Koreja), v njih opredelijo sredstva, potrebna za izvedbo ciljev, vendar ne zgolj kot željo, ampak kot zavezo. Da strategije ne bi bile zgolj mrtva črka na papirju, kot to velja za prvo in bo, kot kaže, tudi za zadnjo raziskovalno-razvojno strategijo, je treba jasno opredeliti proračunske vire sredstev. Ti so lahko obstoječa sredstva ministrstva za znanost, sredstva vlade, ki se $s$ prerazporeditvijo $\mathrm{z}$ drugih področij namenijo za te cilje, ali dodatni proračunski viri.

Leta 2014 je minister Jernej Pikalo imenoval projektno skupino, ki je pod vodstvom Ota Lutharja oblikovala osnutek dopolnitev zakona o raziskovalni dejavnosti - vanj so na moj predlog vključene prej omenjene spremembe. $V$ predlogu zakona so vzvodi za reševanje mnogih strukturnih nedoslednosti, ki jih omenjam $\mathrm{v}$ knjigi, med drugim tudi členi, ki opredeljujejo transparentnost in evropsko primerljive načine reguliranja etičnih standardov. $S$ tega tridesetstranskega besedila od takrat nihče niti prahu ni pobrisal, nov predlog zakonskih sprememb pa je precej boren.

\section{NRRP kot NLP?}

Delo, 29. julij 2004

Letos novembra naj bi po rokovniku agenciji za znanost in tehnologijo, katerih ustanovitev je bila predvidena $v$ novem zakonu, ki ureja področje raziskav in razvoja, pričeli opravljati svoje delo ter s tem prevzeli nase večji del tistega, kar zdaj še opravljata Urad za znanost na Mini- 
strstvu za šolstvo, znanost in tehnologijo ter strokovne službe, zadolžene za področje spodbujanja tehnološkega razvoja na Ministrstvu za gospodarstvo. Do tedaj naj bi poslanci državnega zbora tudi že sprejeli naš nacionalni razvojnoraziskovalni program (NRRP), ki naj bi usmerjal tudi delo omenjenih agencij. Besedi »naj bi« sta tu zelo upravičeni ta čas namrečše ne more nihče napovedati, ali bomo do konca leta res že dobili ta nacionalni program. Tudi proces oblikovanja agencij, še zlasti agencije za tehnologijo, se hudo zapleta in zato je tudi upravičeno vprašanje, ali bo novembra že deloval. K zamudi lahko, seveda, še dodatno prispevajo parlamentarne volitve.

Toda denimo, da bo kljub temu vse šlo bolj ali manj po načrtih ter da bomo tako $v$ prihodnje leto stopili $z$ delujočima agencijam in NRRP. Tudi $v$ tem primeru ne bo nobenega jamstva, da bosta agenciji res neodvisno delovali in da bodo vsi nacionalni program, na katere se nanašata, tudi upoštevani. Namreč, tisti nacionalni razvojnoraziskovalni program, ki ga je sprejel svet za znanost in tehnologijo še med predsednikovanjem sedanjega ministra za zdravje Dušana Kebra, je učinkoval skoraj tako, kot da ga ne bi bilo. Zato se tudi po tistem, ko mu je pred nekaj leti potekel rok veljavnosti, ni zgodilo ničesar usodnega. Ministrstvo je tedaj le za nekaj časa zamrznilo model programske delitve proračunskih sredstev, ko pa novega NRRP le ni hotelo biti, je pri tem uvedlo spremembe, ki naj bi predvidoma dobile podporo $v$ prihodnjem nacionalnem programu. A ta se je doslej tudi tedaj, ko so ga napovedovali kot skorajšnji dokument, obnašal kot nekakšen skrivnostni NLP - neznani leteči predmet. Tisti, ki so ga videli, verjamejo vanj, drugi so nejeverni ali vsaj skeptični. Toda zdaj, ko je zadnja seja sveta za znanost in tehnologijo - tista, zaradi katere je predsedujoči premier Tone Rop zamudil na parlamentarno obravnavo (tedaj še) ministra Dimitrija Rupla - le razkrila prvo različico osnutka $N R R P$, vendar ne kaže več dvomiti, da ta vladni svet in tudi vlada misli z njim zelo resno in da bi ga, če bi bil zanj predviden prednostni postopek obravnave, morda skušala že pred poletjem poslati v parlament.

Vendar je po svoje še sreča, da je zanj določen običajen postopek in se to ne more zgoditi. Sedanji osnutek je namreč podoben na pol vzhajanemu hlebcu kruha. Nihče ne more vedeti, kaj bo še na koncu iz njega nastalo, in če sodimo po prvi razpravi v svetu, se bo v prihodnjih mesecih pojavilo še veliko tistih, ki bi mu radi še kaj dodali ali odvzeli. Bo zato končna peka boljša ali slabša? Verjetno bi bilo modro vztrajati pri takšnem NRRP, ki bo presegal interese posameznikov in tudi posamez- 
nih institucij. Po dosedanjih izkušnjah je to v Sloveniji zelo težko doseči. Morda tudi zato, ker nam ne le v politiki, temveč tudi v znanstveni sferi močno primanjkuje ljudi, ki bi hkrati veljali za vrhunske strokovnjake in popolne poštenjake, da bi tako njihovi poklicni kolegi verjeli v njihovo objektivnost brez zaslonke osebnih interesov.

Prav zato je težko reči, da bo z NRRP in agencijama naša znanstvenoraziskovalno razvojna sfera končno imela vse tiste spodbujevalne mehanizme, ki naj bi bili - kot je bilo v zadnjem času tolikokrat slišati ključni manjkajoči členi razvojnega uspeha. Prav zaradi takšnih razmer doma bo morda ključno vlogo pri našem razvoju v resnici odigrala Era, torej nastajajoči evropski raziskovalni prostor. Zanj je Evropska komisija doslej že razvila kopico spodbujevalnih mehanizmov, ki jih je večinoma sicer vključila v Okvirne programe, mnogi delujejo tudi zunaj teh. Slabost teh evropskih spodbud je $v$ tem, da so obtežene z neverjetno veliko administracije - včasih se skoraj zdi, da ima vsak evropski raziskovalec $v$ Bruslju svojega uradnika. Toda po drugi strani - in to je odlika mehanizmov Ere - je zapletenost postopkov tudi učinkovita varovalka pred tisto domačnostjo, ki tudi omogoča izbiranje raziskovalnih projektov in programov mimo uradnih meril. Tako je s skoraj stoodstotno verjetnostjo mogoče reči, da je tisti, ki je v Bruslju spoznan za primernega in odličnega, tak tudi $v$ resnici.

Kdo in kje so ti dobri in odlični, bo še razvidneje, ko bo zgrajena predvidena mreža evropskih centrov raziskovalne odličnosti in centrov raziskovalne mobilnosti. Kdor jih bo imel, bo s tem dobil tudi odlične raziskovalce od drugod, kdor jih ne bo imel, bo lahko svoje raziskovalce le pošiljal drugam. Slovenija lahko ima še tako razvito lastno raziskovalno mrežo - v Evropi bo nekaj veljala le, če bo z raziskovalnimi zmogljivostmi vključena $v$ skupno evropsko raziskovalno in razvojnotehnološko spodbujevalno omrežje.

Naš nacionalni razvojnoraziskovalni program mora tem evropskim ciljem slediti ali pa je tako in tako obsojen na neuspeh. EU si je že začrtala prednosti raziskovalnih področij, zato je jasno, da tudi naše raziskovalne prednosti ne morejo biti nekaj čisto tretjega, in jasno je tudi, da jih ne moremo imeti $v$ Sloveniji več, kot si jih upa podčrtati evropska vlada. Morda bi bilo torej modro, če bi se enkrat za vselej odločili za evropske razsodnike naših domačih raziskovalnih konfliktov. Seveda to tudi nekaj stane, a verjetno veliko manj, kot bi nas stal še en $N R R P, k i$ bi se na koncu izkazal za NLP. 


\begin{tabular}{ccc}
\multicolumn{3}{c}{ Znanost } \\
Proračunska vlaganja v znanost & $67 \%$ & \\
Število 10\% najbolj citiranih člankov & Gospodarstvo & \\
Vlaganja v R R v gospodarstvu & $148 \%$ \\
Evropski inovacijski indeks & $80 \%$ & \\
B DP na prebivalca & Bruto domači proizvod & \\
& $66 \%$ &
\end{tabular}

Slika 9.1 Primerjave vlaganj v znanost in znanstvenih rezultatov, vlaganj poslovnega sektorja $\mathrm{V} R \mathrm{R}$ in rezultatov ter B D P na prebivalca (v primerjavi s povprečjem E U)

Po podatkih ARRS (https://www.arrs.gov.si/sl/analize/odlicnost).

\section{Kje je Slovenija danes in zakaj bi morale biti znanost in inovacije bistvo slovenske razvojne strategije}

Na sliki 9.1 je zelo poenostavljeno predstavljenih nekaj najosnovnejših podatkov slovenskega inovacijskega prostora: znanost (proračunska vlaganja vanjo in rezultati - odlični članki), gospodarstvo (vlaganja gospodarstva $\mathrm{v}$ razvoj in vrednost evropskega inovacijskega indeksa za Slovenijo) ter B D P (rezultat delovanja vseh družbenih podsistemov).

Primerjave so zanimive. Na eni strani je znanost na univerzah in inštitutih, ki je financirana občutno slabše od evropskega povprečja, njena kakovost pa je v zadnjem desetletju zrasla bistveno nad evropsko povprečje. Na drugi strani je gospodarski sektor, ki je bil deležen občutnih davčnih spodbud in zajetnih državnih subvencij - oboje nad evropskim povprečjem (resda šele od leta 2008 - slika 3.4 na strani 52) -, nadpovprečnega rezultata $\mathrm{v}$ evropskih okvirih pa po indikatorjih kvalitete ne dosega. Tretji del je spodnja slika, B DP na prebivalca, ki je nekakšna skupna slika uspešnosti vseh družbenih podsistemov - tu pa za povprečjem E U že krepko zaostajamo.

Poskušajmo najti odgovore na naslednja vprašanja:

- Zakaj znanost izkazuje tako dobre rezultate?

- Zakaj razvojno-inovacijski rezultati v gospodarstvu dajejo slabše rezultate kot znanost?

- Zakaj državi in drugim akterjem inovacije ne služijo za učinkovitejši in skladnejši razvoj, zaradi česar B D P ostaja krepko pod evropskim povprečjem?

Kje so glavni razlogi za te razkorake, kje se skrivajo pasti za prihodnost? 


\section{Ne dotikaj se moje znanosti}

Delo, 6. julij 2004

Svet za znanost in tehnologijo je med vladnimi sveti svojevrsten fenomen, saj je edini, ki mu predseduje premier, $v$ svoji sestavi pa ima še tri ministre. Tolikšna angažiranost ministrov naj bi seveda potrjevala strateški pomen sveta oziroma pomen področij, s katerimi se ta ukvarja.

Tudi sicer naj bi sestava enaindvajsetčlanskega sveta - v njem je poleg predsednika SAZU, rektorjev in predsednika GZS še pet profesorjev ljubljanske in en profesor mariborske univerze, pet gospodarstvenikov in dva predstavnika raziskovalnih inštitutov - zagotavljala, da bo deloval kot nekakšen svet modrecev.

Čeprav svet $v$ novi sestavi še ne deluje šest mesecev - prvo sejo je imel konec januarja - in bi torej morali s presojanjem o njegovem delu še nekoliko počakati, pa je včerajšnja razprava o tako pomembnem dokumentu, kakor je predlog nacionalnega raziskovalnega in razvojnega programa, ki naj bi prvič tudi jasno določil prednostna področja slovenskega razvoja, pokazala zelo resne pomanjkljivosti $v$ delovanju sveta.

Kajti če bi člani sveta res hoteli služiti slovenski znanosti in razvoju, ne bi večine časa razprave o omejenem predlogu porabili za dokazovanje, da bi moral nacionalni raziskovalni in razvojni program zagotoviti prednost še nekaterim konkretnim razvojnim področjem - po neverjetnem naključju prav tistim, katerih predstavniki so tudi med člani sveta.

Neuspeh na razpisu ministrstva za gospodarstvo - zavrnitev predlagane mreže tehnološke odličnosti - se je prizadetemu članu sveta očitno zdel pomembnejši od vsega, kar naj bi slovenska znanost in razvoj dobila z nacionalnim programom. Kar mučno je bilo poslušati ministra za gospodarstvo Mateja Lahovnika, ki je znova in znova dokazoval, da sam ne more obljubiti drugačne odločitve o tej mreži, da je zanjo še vedno mogoče pridobiti denar iz evropskih strukturnih skladov, in na koncu izrazil upanje, da bo bodoča agencija za tehnološki razvoj ministrstvu prihranila takšno odločanje.

Ta pripetljaj sicer le znova potrjuje že velikokrat izpričano dejstvo, da je $v$ majhni slovenski znanstveni srenji - enako pa velja tudi za visokošolsko in še katero drugo - izredno težko najti visoko strokovne in hkrati objektivne razsodnike. Očitno je pač, da so člani teh svetov, vsaj velika večina, predvsem predstavniki svojih institucij oziroma svojih znanosti in šele nato $v$ službi interesov najširše skupnosti. 
Pri tem niti ni pomembno, ali so res globoko prepričani, da je tisto, za kar se tako vneto zavzemajo, tega tudi vredno. Kajti tudi če mislijo tako, bi morali svoje interese braniti tako, kakor je to omogočeno tistim, ki niso v privilegiranem položaju članov sveta. Kako naj sicer ta svet dokaže svojo verodostojnost?

To verodostojnost pa nedvomno še zlasti potrebuje v razmerah, ko se je naša vlada očitno resno odločila, da se bo ravnala po naših razvojnih potrebah in dogovorjeni evropski politiki in bo v prihodnje veliko bolj podpirala znanost in razvoj, ko je za to "zastavila" tudi svojega prvega človeka in ko naj bi navsezadnje za to dobili tak nacionalni program, $k i$ ne bo le sprejet, temveč bo tudi deloval.

Zdaj je tako, da imamo na eni strani zelo jasno določene lizbonske cilje evropskega razvoja. Za to, da bi jih dosegli, so potrebni res koreniti razvojni premiki, ki jih načelno tudi vsi priznavajo in podpirajo. Na drugi strani imamo "primadone $v$ znanosti in tudi $v$ gospodarstvu. Zares slabo pa je, ko razvajene primadone namesto $v$ gledališču nastopajo $v$ vladnem svetu.

\section{Znanost}

Upravljanje znanosti in njeno financiranje je dokaj urejeno in predvidljivo. Pred osamosvojitvijo je bila za znanost res zadolžena RSs, pozneje pa ministrstva, ki so se ukvarjala tudi z drugimi področji, vendar je RSS vseskozi ohranjala integriteto, dobre prakse, enotno vsebino in precejšnjo avtonomijo. Ohranjali so se tudi bistveni instrumenti financiranja (projekti in programi, mladi raziskovalci, raziskovalna infrastruktura), izpopolnjevali pa so se predvsem načini izbora in preglednost postopkov. Bibliometrijski podatki slovenske znanosti kažejo, da se splošna kultura objavljanja v Sloveniji postopno izboljšuje in ob odličnih raziskovalcih je za podpovprečne vse manj prostora. Zaradi dopolnjevanja univerzitetnih habilitacijskih postopkov se $\mathrm{v}$ naslednjih letih na tem področju obeta nov napredek. Slovenska znanost mora nenehno stremeti $k$ vrhunski znanstveni odličnosti in si postavljati visoke cilje, vredne Nobelove nagrade in drugih prestižnih nagrad, si prizadevati za večje število odobrenih projektov Evropskega raziskovalnega sveta (E RC) in koordiniranje dejavnosti za višje uvrstitve naših univerz na mednarodnih lestvicah. Mnogi podatki so spodbudni, recimo objave v najprestižnejših znanstvenih revijah, kot sta Nature in Science - Slovenija je dve desetletji pred samostojnostjo $v$ teh dveh najelitnejših publikaci- 


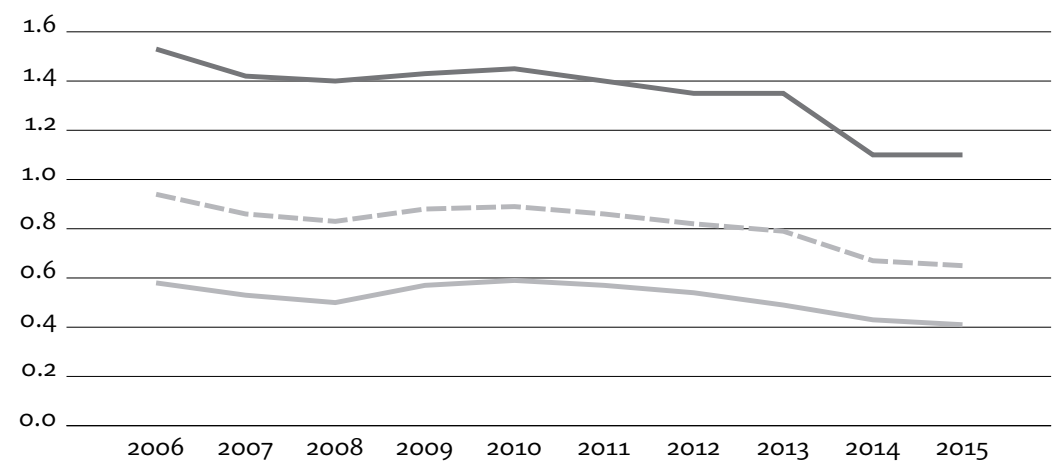

Slika 9.2 Delež slovenskih proračunskih izdatkov za znanost glede na EU

Temno - univerze, svetlo - inštituti, črtkano - skupaj. Po podatkih Eurostata (http://ec .europa.eu/eurostat).

jah beležila v povprečju eno objavo letno, v prvih petnajstih letih po samostojnosti dve objavi letno, zadnje desetletje pa kar trikrat več, $\mathrm{v}$ povprečju eno objavo na vsaka dva meseca.

Uspehi seveda niso samoumevni, in naj so ocenjevalni postopki, transparentnost ter skrb za namensko porabo sredstev še tako inovativni, prevelikega izpada sredstev ne nadomestijo. Slika 9.2, ki prikazuje izračun iz podatkov na sliki 3.3 na strani 47 , kaže, da zadnjih deset let proračunska vlaganja $v$ znanost strmo padajo; prišli smo na raven financiranja znanosti, kakršno smo imeli v sedemdesetih letih prejšnjega stoletja, in tonemo še nižje, evropsko povprečje se zdi vse bolj nedosegljivo. Beg možganov je samo ena od posledic okrnjenega financiranja. Iz grafa lahko jasno razberemo tudi dejstvo, da imajo nizko raven proračunskega financiranja znanosti predvsem univerze - zgolj 40 odstotkov evropskega povprečja, zaradi česar se resnično lahko vprašamo, kako naj univerzitetni profesorji poskrbijo za kakovostno izobrazbo študentov, če sami nimajo skoraj nobene možnosti, da bi aktivno sledili znanstvenemu dogajanju v svetu.

\section{Čas za zmerni optimizem}

Delo, 11. januar 2018

Kaj bo to leto prineslo slovenski znanosti? Bo to prenovljeni zakon o raziskovalno-razvojni dejavnosti ( $Z R R D)$ ? Bo to bistveno okrepljeni znanstveni proračun? Ali nič od omenjenega? 
Začetek zadnjega meseca minulega leta je zaznamovala najprej ostra razprava o predlogu novega $Z R R D$, ki so ga raziskovalci skoraj soglasno zavrnili. Očitali so mu, da zmanjšuje avtonomnost raziskovalnih organizacij, da programsko financiranje zamenjuje z institucionalnim, da ne zagotavlja raziskovalne infrastrukture in da ni usklajen $z$ veljavnim inovacijskim sistemom. Te očitke so raziskovalci povezali še z ugotovitvijo, da trenutno financiranje znanosti ne omogoča učinkovitih izboljšav delovanja raziskovalne sfere oziroma da bi morali ob prenovi zakona povečati proračunski delež znanosti.

Valu kritik pa je hitro sledilo olajšanje ob odločitvi resornega ministrstva, da ustreže zahtevam kritikov predloga omenjenega zakona, ob tem pa je vlada napovedala tudi več denarja za znanost. Tako so zadnji dnevi minulega leta potekali v bistveno prijaznejšem razpoloženju. Toda dejstvo je, da bo lepe napovedi potrebno še potrditi.

Prvo konkretno finančno potezo je prinesel že januar. Prejšnji teden je namreč v resornem ministrstvu izšel razpis, ki ponuja 45 milijonov evrov za spodbujanje izvajanja raziskovalno-razvojnih projektov, ki povezujejo akademsko sfero in gospodarstvo. Izbrani projekti bodo sofinancirani iz Evropskega sklada za regionalni razvoj in sredstev državnega proračuna. Marca, ko se bo iztekel rok za oddajo vlog za omenjeni razpis, bo tudi prva obletnica poziva k razpravi o prihodnjem Devetem okvirnem programu (9. OP) evropskih raziskav za obdobje od 2021 do 2027. Sodeč po objavljenih temeljnih načelih si Evropska unija od raziskovalnih naložb očitno zelo veliko obeta. Na to kaže že okvirni proračun 100 milijard evrov pa tudi to, da bodo raziskave usmerili z jasnimi političnimi in strateškimi cilji ter razvili celovit okvir merjenja njihovega učinka.

EU se nedvomno vse bolj zaveda rasti razvojne konkurence na drugih celinah. Bistveno večja podpora znanosti je očitno edini možen izhod iz grozeče trajne evropske recesije. Gotovo bo tudi omenjena razprava prispevala k večji dodani vrednosti v evropski znanosti. Morda bo ta evropska usmeritev vplivala tudi na slovensko znanstveno politiko, da se ne bi prej omenjene pozitivne spremembe vladne znanstvene politike končale že z naslednjimi parlamentarnimi volitvami, ki bodo, po napovedih, čez skoraj natanko pet mesecev. Verjamete, da bomo v tem razmeroma zelo kratkem obdobju dobili napovedano prenovljeno raziskovalno zakonodajo, ki bo skladna s potrebami naše znanosti in družbenega razvoja? Vsaj v začetku leta se menda spodobi zmerni optimizem. 


\section{Prenos znanja na študente in $\mathrm{v}$ gospodarstvo}

Poskušajmo pojasniti drugi grafikon na sliki 9.1 na strani 155 oziroma dejstvo, da je na evropskem inovacijskem indeksu Slovenija, drugače kot pri kazalcu znanstvene odličnosti, pod evropskim povprečjem. Razvojni uspehi gospodarstva so odvisni tako od inovacijskih aktivnosti samega gospodarstva kot od prenosa znanja $\mathrm{z}$ univerz in inštitutov, ki očitno ne deluje najbolje. Vendar se ne bi rad ustavil pri tej frazi. Kot kažejo podatki, navedeni $v$ knjigi, sklepa gospodarstvo $z$ univerzami in inštituti več pogodb, kot to velja v povprečju za EU. Probleme je torej treba iskati drugje, v kadrih, ki v gospodarstvu skrbijo za razvoj, v diplomantih univerz in doktorjih znanosti. Vse kaže, da diplomanti univerz niso zadovoljivo usposobljeni in da se pri pretoku doktorjev znanosti $\mathrm{v}$ gospodarstvo zatika.

Poglejmo najprej študente. Diplomanti so lahko dobri, če so jih vzgajali dobri profesorji, dobre profesorje pa lahko najdemo le med tistimi predavatelji, ki so tudi dobri raziskovalci - le tako lahko sledijo aktualnim znanstvenim dognanjem in jih predajajo študentom. Slovenska znanstvena geometrija pa je žal taka, da je raziskovanje predvsem domena raziskovalnih inštitutov (veliko bolj kot v E U - slika 7.1 na strani 109) in za raziskovanje na univerzah zato ne ostane veliko sredstev. Pri tem se kar 85 odstotkov raziskovalcev na inštitutih ukvarja pretežno s temeljnimi raziskavami. Oba podatka kažeta, da prenos znanja na študente in $\mathrm{v}$ gospodarstvo ni optimalen. Iz slike 9.3 na naslednji strani lahko razberemo, da je Slovenija povsem na dnu držav E U glede višine sredstev, ki so $\mathrm{v}$ okviru univerzitetnih proračunov namenjena za raziskovanje.

Čeprav so bila številna prizadevanja za povezovanje univerz in inštitutov do zdaj neuspešna, moramo z njimi nadaljevati. Kot lahko razberemo iz slike 7.1 na strani 109 in slike 9.3 na naslednji strani, je to uspelo Estoniji, ki ima s Slovenijo primerljive razvojne ambicije in zgodovino. Da so na najbolj znani lestvici univerz (t. i. šanghajski lestvici) univerze razvrščene predvsem glede na njihov raziskovalni potencial, ni naključje. Univerza v Ljubljani je na tej lestvici prišla med 500 najboljših univerz na svetu, potem pa se je napredovanje ustavilo. Rezultat bi se z reorganizacijo lahko krepko izboljšal; če bi na primer združili IJ S in Univerzo v Ljubljani, bi se Univerza v Ljubljani povzpela za 100 do 200 mest.

Kako povezovanje univerz in inštitutov izvesti? Možne so različne re- 


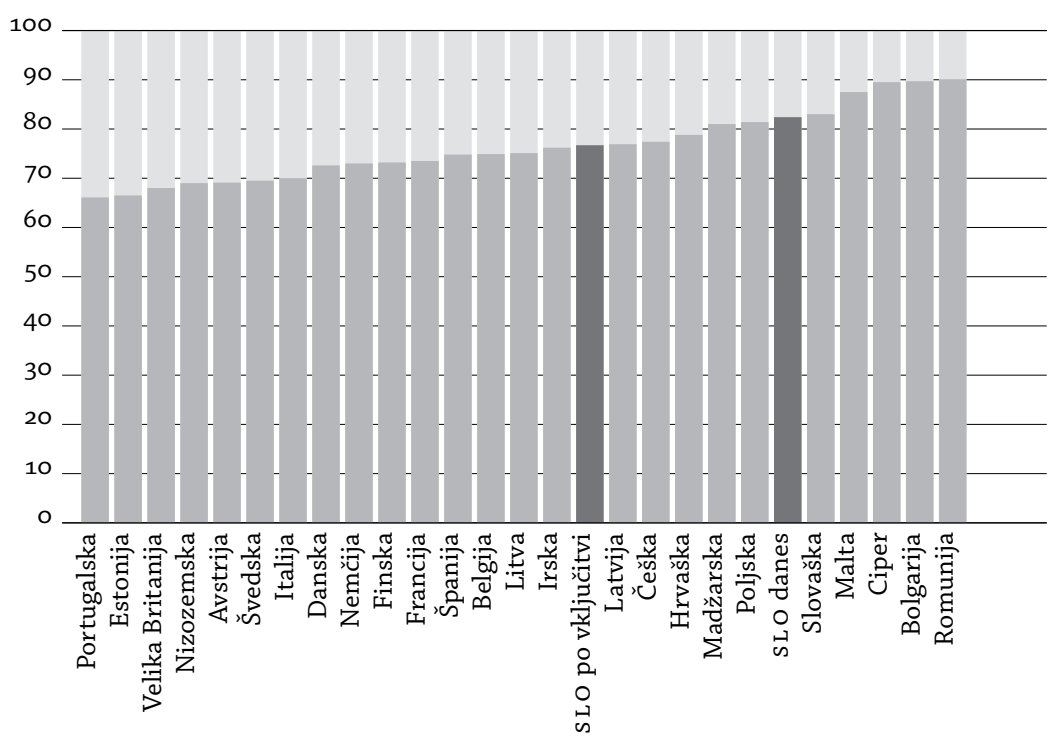

Slika 9.3 Sprememba raziskovalne narave slovenskih univerz z vključitvijo inštitutov v pedagoški proces

Podatke za Slovenijo (s L O danes) smo primerjali s podatki za Slovenijo, če bi polovico sedanjega inštitutskega raziskovanja $z$ inštitutov prenesli na univerze, sorazmeren delež pedagoške dejavnosti pa z univerz na inštitute (s L O po vključitvi). Po podatkih Eurostata (http://ec.europa.eu/eurostat).

šitve. Najpreprosteje bi bilo, da bi se večji inštituti preoblikovali v univerze (za to je potrebna zgolj formalna vloga za spremembo inštitutskega statusa $v$ univerzitetni, ki jo mora potrditi parlament). S statusnim preoblikovanjem bi bilo dobro tudi prerazporediti raziskovalna sredstva - polovico inštitutskih prenesti na univerze, enako količino univerzitetnih sredstev, ki so namenjena pedagoški dejavnosti, pa na inštitute -, za tak postopek bi zadostoval poseben zakonski člen. Slika 9.3 kaže, da bi se $s$ to potezo raziskovalni delež na slovenskih univerzah približal evropskemu povprečju. $\mathrm{Na}$ inštitutih je na mnogih področjih zaposlenih dovolj strokovnjakov, ki so ali bi lahko bili izvoljeni v visokošolske nazive, zato bi se lahko takoj vključili v pedagoški proces. Večjih težav na mikronivoju, torej individualnih težav, pa zaradi prepletenosti raziskovalnih programov, ki povezujejo raziskovalno dejavnost univerz in inštitutov, ne bi smelo biti.

S statusnim preoblikovanjem bi bili potenciali inštitutov bolj izkoriščeni in to $\mathrm{v}$ korist študentov, univerze pa bi pridobile veliko raziskovalnih sredstev, kar bi izboljšalo njihovo kakovost. Sprememba bi bila 
torej vsesplošno, lahko bi rekli nacionalno koristna. Poleg tega bi tudi izdatno razbremenila pedagoško delo profesorjev.

Druga možnost je združevanje ustanov, primerna predvsem za manjše inštitute, ki bi jih kazalo priključiti obstoječim univerzam. Za to obstaja več načinov, njihova izvedba ni težavna in ne zahteva znatnih dodatnih sredstev, edini problem je - sama odločitev. Ena od možnosti povezovanj univerz in inštitutov bi bila tudi ustanovitev tehniškonaravoslovne univerze, ki bi združila inštitute in nekatere fakultete ljubljanske univerze. Iz slike 6.4 na strani 100 pa bi lahko izpeljali tudi sklep: zamrznimo financiranje raziskovalnih inštitutov in obsežna sredstva namenimo za raziskovanje na univerzah.

Pred leti sem Janezu Potočniku, ki je bil takratni evropski komisar za raziskave in razvoj, predlagal, da bi I J S vključili v Joint Research Center (J RC), evropski sistem raziskovalnih inštitutov, ki jih financira Evropska komisija. S tem bi dosegli vrsto sinergij. E U bi dobila izvrsten inštitut, ki bi prispeval k dvigu evropske znanstvene kvalitete, za Slovenijo pa bi poteza pomenila bistveno finančno razbremenitev. Slovenija bi zato lahko znatno višji delež raziskovalnih sredstev namenila univerzam, kar bi vplivalo na izdatno izboljšavo njihove kakovosti in posledično seveda tudi kakovosti kadrov. Hkrati bi Slovenija postala država, ki za celotno raziskovanje namenja približno tolikšen delež sredstev kot EU. Ne vem, če se bo takšna priložnost še kdaj ponudila. Potočnik me žal ni razumel ali pa je ocenil, da je projekt težko izvedljiv.

Pri določanju razmerja med univerzami in inštituti je treba upoštevati še dodatni vidik, kvaliteto in organizacijsko kulturo ustanov. Slovenski inštituti imajo zaradi premajhne vpetosti v pedagoški proces in $\mathrm{v}$ gospodarstvo težave glede poslanstva $\mathrm{v}$ slovenskem prostoru. Ker so pretežno usmerjeni le $\mathrm{v}$ temeljno znanost, je njihovo sodelovanje $\mathrm{z}$ gospodarstvom šibko, $\mathrm{s}$ tem pa tudi delovanje $\mathrm{v}$ širšem družbenem okviru.

Po drugi strani so inštituti dokaj dobro organizirane ustanove, vsi bistveni elementi, ki jim jih predpisuje agencija, dobro delujejo: poraba raziskovalnih sredstev je sistemsko dobro normirana, $\mathrm{z}$ mehanizmom kratkoročno odloženih prihodkov se 10 odstotkov sredstev letno prenese v naslednje leto, zaradi česar je raziskovalna dejavnost bistveno racionalnejša od ostalih delov javnega sektorja. Zaradi pravilnika ARRS, ki inštitute spodbuja, da je struktura znanstvenih nazivov zaposlenih primerljiva s strukturo v E U, kjer je znanstvenih svetnikov manj kot 20 odstotkov, se na glavo obrnjena slovenska piramida znanstvenih nazi- 
vov na inštitutih hitro izboljšuje. Inštituti razpolagajo $z$ dobro raziskovalno opremo, Institut "Jožef Stefan", pojem znanstvene odličnosti pri nas, pa je povsem primerljiv s podobnimi ustanovami v svetu.

Poslanstvo univerz je, drugače kot pri inštitutih, povsem jasno - izobraževanje dobrih strokovnjakov, ustvarjanje nove kadrovske elite $\mathrm{v}$ Sloveniji. Ker pa je višina sredstev za njihovo raziskovalno dejavnost med najnižjimi v Evropi, je tudi znanstvena raven marsikaterega oddelka nizka. Slovenske univerze poleg tega svojega poslovanja očitno niso korektno uredile. To lahko sklepamo po vrsti vzporednih nelegalnih in pollegalnih izplačil stimulacije, kot so sporni avtorski honorarji in dodatki za stalno pripravljenost.

\section{Ni modro hujšati možganov, pravijo znanstveniki}

Peticija vladi - Opozorilo, da bo gospodarski zagon odvisen od znanosti, ima že več kot tisoč podpisov - Varčevanje v znanosti škoduje Delo, 5. april 2012

Ljubljana - Konec marca je bil na spletni strani www.znanost.biz objavljen javni poziv vladi, naslovljen Znanost in tehnološki razvoj sta rešitev za izhod iz gospodarske krize. Peticija, katere pobudnikje prof. dr. Roman Jerala, je doslej zbrala že več kot tisoč podpisov znanstvenikov, razvojnikov iz gospodarstva in drugih slovenskih razumnikov.

"Menimo, da lahko znanost, tehnologija in visokošolsko izobraževanje najbolj prispevajo $k$ ponovni rasti slovenskega gospodarstva. Pomembno je vlaganje $v$ razvoj, in ne finančni rezi, ki bodo dolgotrajno oslabili znanstveno-tehnološko podlago. Financiranje terciarnega izobraževanja na študenta je bilo že doslej prenizko in število strokovnjakov v tehniki, naravoslovju in medicini že doslej ni zadostovalo potrebam razvite družbe in visokotehnološko razvitega gospodarstva. S krčenjem financiranja in posledičnim odpuščanjem mladih strokovnjakov, ki jih oslabljeno gospodarstvo ne bi zmoglo vključiti, bi še dodatno povzročili odliv strokovnjakov v tujino, preden bi ti začeli družbi vračati investicije v njihovo izobraževanje. To pa je s stališča nacionalnega gospodarstva najbolj potratno, " med drugim piše v peticiji znanstvene sfere, ki jo je podpisal tudi rektor mariborske univerze (UM). „Če hočemo ponovno zagnati razvoj, je treba znanost in visokošolsko izobraževanje ohraniti $v$ dobri kondiciji. Moramo pa univerze izboljšati svoje delovanje. A svoj del prevzemamo z vso odgovornostjo, "nam je svoj pogled jedrnato predstavil rektor UM prof. dr. Danijel Rebolj. 


\section{Predlogi drugačnega uravnoteženja}

Med najaktivnejšimi podporniki peticije in kritiki vladne varčevalne politike je prof. dr. Oto Luthar, direktor ZRC SAZU in predsednik koordinacije raziskovalnih institucij KOSRIS: „Še posebno težko se je sprijazniti s spoznanjem, da tudi ta vlada misli, da je mogoče prihraniti zgolj $z$ odrekanjem, oziroma da je $v$ celoti pozabila, da je mogoče določeno dejavnost racionalizirati tudi z nagrajevanjem tistih, ki znajo in hočejo pridobiti sredstva na različnih razpisih in na podlagi dobrega sodelovanja z gospodarstvom v najširšem smislu. "Direktor ZRC SAZU vladi priporoča drugačne ukrepe za uravnoteženje - vsaj skromno povečanje raziskovalnega proračuna, podporo sodelovanju med univerzami in raziskovalnimi inštituti, povečanje programskih deležev financiranja po evropskih zgledih, odprte razpise...

Pozanimali smo se tudi za stališča nekaterih uglednih članov akademske sfere, ki jih ni med podpisniki. Prof. dr. Vito Turk, raziskovalec in direktor Mednarodne podiplomske šole "Jožefa Stefana", peticije ni podpisal, ker "je splošna in govori o znanih stvareh «. Za vladne varčevalne ukrepe pravi, da bo krčenje sredstev $v$ znanosti povzročilo škodo, ki je dolgo ne bo mogoče popraviti, opozarja tudi na to, da so Avstrija, Nemčija in druge evropske države $v$ krizi še okrepile naložbe $v$ znanost. »Vsaka racionalizacija zahteva temeljit premislek in analizo, da se ne bi delala škoda. Tudi v znanosti je treba določene stvari urediti, in ne podpirati kar povprek povprečništva. Le odličnost je nosilec napredka, in to je osnovni kriterij, ki ga moramo upoštevati. Tudi v kriznih časih."

\section{Odpor proti uravnilovskim ukrepom}

Med nepodpisniki tega apela sta tudi direktorja osrednjih raziskovalnih institucij, Instituta »Jožef Stefan (IJS) in Kemijskega inštituta (KI), prof. dr. Jadran Lenarčič in prof. dr. Janko Jamnik. "Samo varčevanje ne zadostuje, treba je iskati rešitve, ki bodo prispevale $k$ ponovnemu zagonu gospodarstva. Preseči moramo pritiskanje s katere koli strani, potrebna sta konstruktivni dialog in sodelovanje. Nisem za pavšalne ukrepe in tudi ne za pavšalne peticije. $Z$ ustreznimi argumenti je treba selekcionirati ukrepe, da bi preživeli mesec, morda pa tudi izkoristiti trenutek za tiste strukturne spremembe, ki bodo povečale našo učinkovitost in doprinos v prihodnje, "svoje stališče pojasnjuje direktor IJS. Za direktorja KI, ki, kot pravi, peticij načeloma ne podpisuje, so predvideni varčevalni ukrepi vlade "nujno zlo", pravi pa, da se ne more strinjati z ukrepi, ki bi posegli »po zunajproračunskih prilivih, na primer tistih, 
ki jih ustvarimo s sodelovanjem z gospodarstvom«. Upa tudi, da vlada raziskovalcev pri delu ne bo zmotila z ukrepi, ki bodo "dišali po uravnilovki«. Jamnik in Rebolj vlado opozarjata, da ni modro »hujšati možganov « in da - po besedah direktorja Kemijskega inštituta - ne smemo zaradi varčevalnih ukrepov tvegati izgube desetih odstotkov najboljših raziskovalcev.

\section{Odpovedana seja sveta za znanost in tehnologijo}

Včeraj zjutraj bi se morala na skupni seji sestati vladni svet za znanost in tehnološki razvoj (SZT) in Strateški svet za tehnološko politiko pri Gospodarski zbornici Slovenije. A se nista, ker, kot nam je povedal predsednik sZT dr. Marko Jaklič, ki je tudi med podpisniki peticije, resorni minister Žiga Turk zaradi neodložljivih opravkov ni imel časa za udeležbo ne ob napovedani ne ob kakšni poznejši uri. »Na seji smo želeli predstaviti tudi peticijo, ki sicer ni peticija našega sveta. Brez ministra pa se nam sestanek ni zdel smiseln, "je povedal Jaklič, ki je na naše vprašanje, ali meni, da se je minister zavestno izognil soočenju s predstavniki znanstveno-tehnološke sfere, odgovoril, da o tem noče ugibati. "Načrtovano varčevanje $v$ znanosti in odklon od sprejete inovacijskoraziskovalne strategije sta vsekakor temi, ki bi ju moral obravnavati naš svet. Vendar smo mi vladni svetovalni organ, svetovati pa ni mogoče nekomu, ki nasveta ne potrebuje ali noče."

\section{V gospodarstvu je še vedno premalo doktorjev znanosti}

V Sloveniji gospodarstvo zaposluje 25 odstotkov vseh doktorjev znanosti, kar ni tako slabo, a je še vedno precej manj kot, denimo, v Z D A ali na Danskem, kjer je ta delež 35-odstotni. Toda bolj kot delež doktorjev znanosti odstopa višina njihovih dohodkov v gospodarstvu - v vseh drugih državah, $v$ razvitih pa še posebno, so doktorji znanosti $v$ gospodarstvu bolje plačani kot v akademski sferi (Auriol, Misu in Freeman, 2013; Arsenjuk, 2015). Slovenija je povsem na repu te lestvice - povprečni plači slovenskega doktorja znanosti $v$ gospodarstvu in $\mathrm{v}$ javnem sektorju sta enaki. $\mathrm{V}$ to primerjavo niso všteti raznovrstni dodatki, ki raziskovalcu $\mathrm{v}$ javnem sektorju lahko pripadajo, kar pomeni, da je plača doktorja znanosti v gospodarstvu pri nas celo nižja kot v javnem sektorju.

Razlog za to je med drugim treba iskati v neusklajenosti vladnih ukrepov. AR R S je s projektom mladih raziskovalcev bodočim doktorjem znanosti res omogočila ugodne izobraževalne pogoje, vendar država pri 


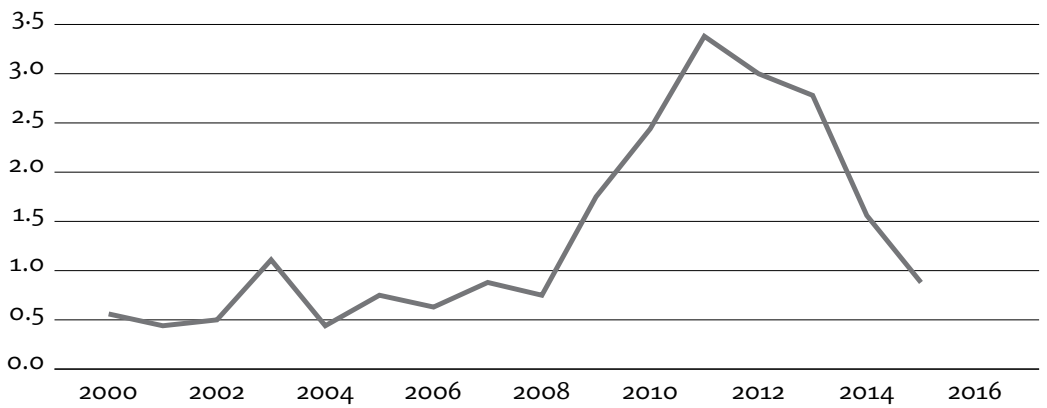

Slika 9.4 Delež slovenskih proračunskih izdatkov za RR v gospodarstvu glede na E U

Po podatkih Eurostata (http://ec.europa.eu/eurostat).

tem ni poskrbela za socialno kapico, s katero bi doktorji znanosti postali za gospodarstvo finančno konkurenčni in s katero bi jim ponudili evropsko primerljive spodbude za ustvarjalno delo (višje dohodke v gospodarstvu kot v akademskem okolju). Poleg tega se pri tem ključnem vzvodu prenosa znanja zatika tudi zato, ker med univerzami in gospodarstvom ni sistemsko urejenega sodelovanja. Pri vsaki razpravi na to temo se o socialni kapici vedno govori le na splošno, pri čemer jo njeni nasprotniki dosledno razumejo kot mehanizem za še večje plače vodilnih menedžerjev v podjetjih. Socialna kapica bi morala biti zato vsebinsko strukturirana, in to tako, da bi spodbujala zaposlovanje doktorjev znanosti v razvojnih oddelkih gospodarstva.

Razvojno-inovacijske aktivnosti v podjetjih poleg tega šepajo tudi zaradi premajhnih finančnih spodbud, ki so se povečale šele po letu 2008, a že resno kaže, da spet upadajo. »Resolucija o raziskovalni in inovacijski strategiji Slovenije 2011-2020 (2011, v nadaljevanju RISS) je v obdobju po letu 2010 predvidela bistveno okrepitev raziskovalno-inovacijskih dejavnosti. Država se je zavezala, da bo krepko povečala finančna sredstva za tehnološke projekte $\mathrm{v}$ gospodarstvu, vendar slika 9.4 prikazuje povsem nasprotno sliko. Slika 9.4 prikazuje vlaganje države v gospodarstvo, ki se je pred krizo povečalo, nato pa padlo na predkrizno raven. Začetni zagon vlaganja je $\mathrm{z}$ nastopom finančne krize povsem izpuhtel.

Padec vlaganja države v gospodarstvo je zaskrbljujoč, vlaganje slovenskega gospodarstva $\mathrm{v}$ razvoj pa ostaja obetavno, saj se ni krčilo, $\mathrm{k}$ čemur močno prispevajo davčne olajšave (slika 3.4 na strani 52). Mogoče pa bi kazalo ta mehanizem nadgraditi: polovico davčnih olajšav bi lahko namenili za raziskovalne projekte, ki bi jih univerze in inštituti 
- te bi izbirali v gospodarstvu - namensko izvajali za tiste gospodarske družbe, ki uveljavljajo davčne olajšave. Leta 2005 se je v Sloveniji intenzivno razpravljalo o uvedbi enotne davčne stopnje, ki bi prinesla predvsem davčno razbremenitev za tiste $\mathrm{z}$ visokimi prihodki, zaradi česar naj bi podjetjem ostalo več denarja, s tem pa tudi več sredstev za vlaganje v razvoj. Enega od vodilnih zagovornikov tega modela sem na eni od predstavitev povprašal, zakaj je tako prepričan, da se bodo dodatna sredstva, ki bodo ostala v podjetjih, zares porabila za njihov razvoj, ne pa za dobičke, privatizacijo ... Njegov odgovor me ni prepričal in naslednja leta so pokazala, da moj pomislek ni bil odveč. Uspešne države v svojo ekonomsko politiko vključijo tudi zelo podrobne izvedbene mehanizme in se ne zanašajo zgolj na pavšalne ekonomske teorije.

Tretjina davčnih olajšav za raziskave in razvoj danes znese približno 100 milijonov evrov. Č bi bila ta sredstva namensko porabljena za ciljno sodelovanje med gospodarstvom in akademsko sfero, bi se sodelovanje med njima lahko precej okrepilo. A treba je opozoriti, da davčne olajšave niso samoumevne; spomnimo se na primer leta 2015, ko je finančni minister Dušan Mramor - resda neuspešno, pa vendar - predlagal, da bi višino teh olajšav prepolovili.

Podatki o proračunskem financiranju znanosti na univerzah in inštitutih ter podatki o trendih proračunskega financiranja razvoja $v$ gospodarstvu so porazni - Sloveniji napovedujejo mračno prihodnost. Finančna kriza je očitno porušila prejšnja prizadevanja, da bi se vzpostavil dobro delujoč nacionalni inovacijski sistem. Nekaj upanja vzbujajo evropska sredstva Pametne specializacije, ki bi po višini finančnih sredstev deloma lahko nadomestila zmanjšanje vlaganj države $v \mathrm{R} R \mathrm{v}$ gospodarstvu in mogoče tudi na univerzah in inštitutih. Iz podatkov pa lahko izpeljemo še en sklep, o katerem sem govoril tudi v predavanju Odličnost in kohezija na letni konferenci visokih vladnih predstavnikov za področje znanosti v estonskem univerzitetnem mestu Tartu: razlog, da predvsem manj razvite evropske državah ne morejo doseči dviga vlaganj V R R, je obenem vzrok za njihovo nerazvitost - da vse do danes niso dojele pomena vlaganj v R R. Vrzel med razvitimi in nerazvitimi v Evropi se bo zato samo še povečevala (slika 6.1 na strani 92).

$\mathrm{V}$ predavanju sem predlagal, da bi razvili mehanizme za porabo kohezijskih sredstev E U (sredstev za enakomeren razvoj znotraj E U), ki bi bila namenjena za razvojne projekte manj razvitih regij. Ideja je padla na plodna tla in na konzultacijah v kabinetu takratnega predsednika evropske komisije Joséja Manuela Barrosa smo v sodelovanju z neka- 
terimi komisariati EU koncept mehanizmov tudi natančneje določili. Nastal je program Pametna specializacija, ki danes temu namenja 80 milijard evrov in bo zelo pomemben tudi za Slovenijo ("Strategija pametne specializacije«, 2015).

Dobro delujoči inovacijski sistem je verjetno največji izziv bodočega gospodarskega razvoja Slovenije, temelje zanj pa bomo morda našli prav v programu Pametna specializacija, ki bo v naslednjih letih pomemben vir sredstev za tvorno povezovanje akademske znanosti in gospodarsko perspektivnih panog. Res pa je, da je namen tega evropskega programa ciljno povečanje vlaganj v R R in ne zgolj nadomestitev državnih sredstev $\mathrm{z}$ evropskimi.

\section{Doktorji znanosti v našem gospodarstvu}

Gospodarska kriza dviguje vrednost znanja - Na okrogli mizi Instituta »Jožef Stefan « so povedali, kaj privablja doktorje znanosti v naša podjetja in kaj jih odganja iz njih - Tatjana Fink in Ivo Boscarol menita, da slovenski izobraževalni sistem podpira lenobo in ležernost Delo, 23. junij 2011

Ljubljana - Na našem največjem raziskovalnem Institutu »Jožef Stefan «(IJS) že ves teden potekajo dogodki v okviru tako imenovanih Štefanovih dnevov ob obletnici rojstva velikega fizika, po katerem nosi ime IJS. V okvir teh prireditev je sodila tudi predvčerajšnja okrogla miza o doktorjih znanosti $v$ gospodarstvu. V Sloveniji že vrsto let poslušamo razprave, v katerih ugotavljajo, da bi lahko bistveno izboljšali učinkovitost našega gospodarstva in njegovo dodano vrednost, če bi kadrovsko sestavo podjetij okrepili z doktorji znanosti. Tako izobraženi strokovnjaki pa so bili v naših podjetjih z redkimi izjemami kljub vsem spodbudam takšnemu zaposlovanju dolgo bele vrane. To se je v zadnjem času menda le začelo spreminjati.

Kot so ugotavljali na omenjeni okrogli mizi, je k temu spreminjanju menda pomembno prispevala gospodarska kriza, $v$ kateri so se podjetja bolj zavedela pomena lastnega razvoja in raziskav. A razmerja med doktorji znanosti v gospodarstvu in $v$ drugih sektorjih so pri nas še vedno izrazito neugodna - po besedah prof. dr. Jadrana Lenarčiča, direktorja IJS, ki je vodil pogovor, je v Sloveniji trenutno v gospodarstvu le kakšnih 300 doktorjev znanosti oziroma približno pet odstotkov vseh doktorjev znanosti. Preostali so zaposleni na raziskovalnih inštitutih, $v$ visokošolskih institucijah, državni upravi ter drugod. 


\section{Strokovnjake $v$ podjetja, ne v birokracijo!}

Lenarčič je poudaril, da je ta podatek le ocena, saj kljub prizadevanju ni našel vira, ki bi pokazal, kako se zaposlujejo naši doktorji znanosti.

Direktor IJS je povedal tudi, da je približno 65 odstotkov vseh doktorjev znanosti na področju tehnike in naravoslovja ter da bo ob predvideni rasti števila študentov doktorskih študijev od 20 do 30 odstotkov teh po opravljenih doktoratih moralo poiskati službe zunaj raziskovalne sfere. Lenarčič je to napoved pospremil s komentarjem, da si želi, da bi ti strokovnjaki odhajali v podjetja, in ne v birokracijo.

Sodeč po mnenjih na okrogli mizi se v našem gospodarstvu že bistveno spreminja mnenje o tem, koliko so vredni doktorji znanosti. K temu bistveno prispeva tudi to, da se doktorski študenti s podjetji povezujejo že v času svojega študija in svoje doktorske teme neposredno povezujejo s konkretno problematiko podjetij. Tatjana Fink, glavna direktorica družbe Trimo, je v zvezi z našim vrednotenjem doktorjev znanosti v gospodarstvu povedala, da je v tujini za te kadre delo v podjetjih čast, in ne nekaj manjvrednega, pri nas pa še vedno velja, da je bolje delati na inštitutih. So pa tudi pri nas doktorji znanosti v gospodarstvu praviloma bolje plačani od inštitutskih. Po mnenju razpravljavcev pa bi jim morali omogočiti še boljše plače, kar naj bi dosegli s tem, da bi plače teh, ki največ prispevajo, manj obdavčili.

\section{Trimu dobre izkušnje $\mathrm{z}$ doktorji znanosti}

Finkova je povedala tudi, da imajo $v$ Trimu zelo dobre izkušnje z doktorji znanosti, $k$ njihovemu dobremu vključevanju pa je verjetno pripomogla dobra izobrazbena struktura celotnega kolektiva. Direktorica tega podjetja meni, da se najboljše ideje rojevajo takrat, ko se zbere zadostna kritična masa strokovnjakov. Poudarila je tudi potrebo po zaupanju in potrpežljivosti, ker je "vsak razvoj proces, v katerem iščeš, česar še ni«, pri tem pa nastajajo zastoji in tudi napake.

Ivo Boscarol, direktor in lastnik podjetja Pipistrel, je spomnil na projekt Tisoč doktorjev znanosti $v$ slovensko gospodarstvo, s katerim se je ukvarjal v strateškem svetu prejšnje vlade. Takrat so si zamislili, da bi takšne zaposlitve spodbudili s tem, da bi plačam, ki jih tem kadrom zagotavlja gospodarstvo, dodali še proračunski delež. Tudi Boscarol je opozoril na škodljive posledice sedanje pretirane obdavčitve plač. Povedal je, da ga je zaposlitev doktorja znanosti iz Nemčije z enako plačo, kot bi jo ta imel $v$ Nemčiji, stala dodatnih 1.700 evrov prispevkov.

Ne Finkova ne Boscarol nista zadovoljna s slovenskim izobraževal- 
nim sistemom, ki, po njunem mnenju, podpira lenobo in ležernost. To se - je dejala Finkova - pozna tudi pri tem, da diplomanti težko sledijo tempu dela. Vseeno pa je Boscarol pohvalil tudi domače doktorje znanosti, ki se zaposlujejo v njegovem podjetju. Dejal je, da imajo širino, da jih ni težko vključiti v proizvodnjo in niso v ničemer akademsko zadrti.

Dr. Igor Muševič, vodja odseka za fiziko trdne snovi na IJS, je v tej razpravi opozoril, da vseh doktorjev znanosti ni mogoče usmeriti v gospodarstvo, ker so njihovi interesi in sposobnosti tako različni, da so eni primernejši za delo na inštitutih in univerzah, drugi pa v podjetjih. Po Muševičevi oceni bi morali mentorji pomagati doktorandom, da najdejo tisto delo, kjer bodo najkoristnejši.

\section{Zakaj imamo nižji odstotek BDP na prebivalca?}

Knjiga Slovenska znanost osvetljuje našo znanost zadnjega četrt stoletja predvsem $\mathrm{z}$ vidika finančnih virov, $\mathrm{s}$ katerimi je $\mathrm{v}$ tem času razpolagala, in rezultatov, ki jih je dosegala. Hkrati analizira tudi vpetost znanosti v naše gospodarstvo. Razmisleki o družbeni vlogi znanosti se običajno na tej točki končajo; uspešnost znanosti se ocenjuje zgolj na podlagi povezav teh dveh podsistemov (znanosti in gospodarstva). A ne bi se smeli ustaviti tu - za uspeh družbe je pomembno delovanje vseh podsistemov.

Podatki Globalnega indeksa konkurenčnosti kažejo, da je Slovenija šibka na področjih trga dela, finančnega trga, trga dobrin, tujih investicij (slika 6.4 na strani 100), v precej manjšem razkoraku z E U pa je na področjih inovacij in tehnološke usposobljenosti (slika 6.5 na strani 100). Zakaj?

\section{Nismo Avstrija. Žal res ne.}

Delo, 4. maj 2012

Slovenski raziskovalci, tudi družboslovci in humanisti, se zadnja dva tedna ubadajo z matematiko. Poskušajo namreč izračunati, kaj jim bo ostalo, ko si bo vlada - če bo ostalo pri sedanjih predlogih varčevalnih ukrepov - odrezala svoj »kos mesa iz javnih sredstev, na katera so letos računali. Za zdaj jim vsi izračuni kažejo, da bodo po tem posegu njihove institucije izkrvavele oziroma samo še životarile. Inštituti, ki naj bi bili med ključnimi akterji našega preboja iz krize, bodo po napovedih postali nekakšni zombiji. 
Sicer pa so na nedavni novinarski konferenci Koordinacije samostojnih raziskovalnih institucij Slovenije (KOSRIS), na kateri so napovedali javni poziv vladi, sedanje razmere $v$ naši znanosti primerjali tudi $z$ ladjo, polno nesrečnih duš zaradi vladne nekompetentne varčevalne politike. Pretiravanje? Verjetno ni pretiraval direktor našega največjega inštituta prof. dr. Jadran Lenarčič, ki je povedal, da desetih milijonov, kolikor naj bi bilo letos zanje manj javnih sredstev, ne bi mogli privarčevati, niti, „če bi sredi leta odpustili vse raziskovalce Instituta »Jožef Stefan«, vključno z menoj«. Kvečjemu bi morda zmogli polovični rez.

Res si je težko predstavljati varčevanje na račun nevzdrževanja dragih in občutljivih naprav ali morebitnega izklapljanja elektrike. So pa tudi inštituti, katerih edina omembe vredna lastnina so ljudje in knjižnice. Bi jih morali »dati na grmado«, da bi država dovolj privarčevala? Kako pa bo varčevala takrat, ko bo ob morebitnem zlomu znanosti ugotovila, da je s tem "privarčevala« še zlom gospodarstva? Da bi bilo veliko bolj modro, če bi znanosti, namesto da ji zavija vrat, z davčnimi olajšavami in drugimi ukrepi omogočila boljše sodelovanje z gospodarstvom. Iz česar bi navsezadnje - a ne čez noč - dobila veliko več, kot si obeta zdaj. Sočasno s temi dramatičnimi napovedmi raziskovalcev nas je prvič obiskala evropska komisarka za raziskave in inovacije. Pohvalila je dosedanja slovenska vlaganja $v$ znanost in izrazila upanje, da bomo kljub spopadanju s krizo še naprej podpirali to področje, pač po zgledu drugih držav. Bilo je skoraj idilično, ampak saj drugače niti ni moglo biti. Pred tujci se ne blati domače politike, komisarka pa tudi ni pristojna za konkretno vmešavanje $v$ naš način varčevanja; poleg tega je $k$ nam prišla po podporo programu Obzorje 2020, »težkemu« 80 milijard.

Nanje računajo tudi naši raziskovalci, toda ob načrtovanem rezanju vsi ne bodo mogli niti kandidirati, saj ne bodo imeli denarja za obvezno participacijo. "Mi nismo Avstrija, "nam je minuli četrtek, med obravnavo vladnih varčevalnih ukrepov na nočni seji parlamentarnega odbora za izobraževanje, visoko šolstvo, kulturo, šport in mladino, odvrnil minister Turk, ko smo ga vprašali, zakaj si Avstrija lahko privošči, da med krizo visoko šolstvo in znanost podpre celo bolj kakor prej. A vendar menda se pač bolj želimo približati Avstriji, kakor pa biti valilnica talentov za Avstrijo in še katero pametno državo?

Ključni proces praktično celotnega obdobja slovenske države je bil proces privatizacije gospodarstva. Bralcem priporočam, da preberejo 
knjigo Bineta Kordeža Kam je izginilo deset milijard? (Kordež, 2015). Avtor na več kot 400 straneh in $\mathrm{z}$ desetinami grafikonov razlaga dogajanje v slovenskem gospodarstvu v času samostojne Slovenije - mislim, da nikjer ne omeni razvoja. Razvoju so osrednje mesto namenila le vodstva nekaterih podjetij. Večinoma pa se vse vrti okrog posojil, privatizacije in preprodaj delnic. Pravzaprav je pravo čudo, da po takem obdobju sploh še dosegamo 66 odstotkov evropskega povprečja BD P.

Plenjenje gospodarstva gre $\mathrm{z}$ roko $\mathrm{v}$ roki s slabim upravljanjem države. Verjetno se spomnimo obdobja izpred nekaj let, ko je imela vlada pri finančni krizi praktično zvezane roke, saj je vsakemu ukrepu sledil referendum. Tudi proračunska nedisciplina, ki je povzročila stalno zadolževanje države, je bila ena od v nebo vpijočih neurejenosti pri upravljanju države. Uspešne države javnim ustanovam zagotavljajo avtonomijo, to je samoumevni del njihovega upravljanja, v gospodarstvo in javni sektor se kaj dosti ne vpletajo (Acemoglu in Robinson, 2015). V knjigi govorim o pomenu avtonomije za univerze, inštitute in AR R S, ki pa še kako velja tudi za celotni javni sektor. Zanimivo je, da je avtonomija javnih ustanov, ki delujejo na področju znanosti, večja od avtonomije drugih javnih ustanov, zato bi jo veljalo vzeti za izhodišče pri upravljanju javnega sektorja. V uspešnejših družbah znanje učinkoviteje spodbuja napredek prav zato, ker sta tako javni sektor kot gospodarstvo manj odvisna od politike kot pri nas (Demšar in Zatler, 2018)

Leta 2007 sem na podlagi obstoječih statističnih podatkov o vlaganjih $\mathrm{v}$ raziskave in razvoj od leta 1995 sestavil grafikon, ki je prikazal linijo trenda na tem področju. Enostavni izračun je prinesel tale sklep glede naše prihodnosti: Slovenija bo bolonjski cilj treh odstotkov vlaganj v raziskave in razvoj dosegla leta 2187. Finance so izračun celo razglasile za izjavo meseca, vendar pa se je v letih, ki so sledila, spremenilo veliko stvari. Davčne olajšave so začele delovati, država se je odzvala $z$ okrepljenimi državnimi subvencijami, namenjenimi razvoju v gospodarstvu - dogajanje je spominjalo na osemdeseta leta prejšnjega stoletja, ko se je vlaganje v razvoj izdatno povečalo -, in bolonjski cilj smo že leta 2013 skoraj dosegli. Če preletimo grafikone v knjigi, lahko opazimo velika nihanja, taka dinamika pa pomeni nepredvidljivost. In prav taka je tudi slovenska bodočnost. 


\section{Zahvale}

Za posredovanje nekaterih podatkov se zahvaljujem svojim nekdanjim sodelavcem na A R R S Poloni Novak, Stojanu Pečlinu, Marjanu Brezovarju, Marku Perdihu, Lili Lucić, Primožu Pristovšku, Ernesti Mlakar, Tini Vuga, Mojci Kastelc Selan, Dubravki Krneta, Mitji Tomažiču in Zdenku Nemcu ter sodelavki IZ U M Lidiji Curk. Za pozorno branje rokopisa se zahvaljujem Milošu Komacu, Janezu Slaku in Petru Stanovniku.

Franci Demšar

Zahvaljujem se zlasti vsem bivšim in sedanjim zaposlenim v znanstveni redakciji Dela. Znanstveno novinarstvo nam je vsem zlezlo pod kožo in ves čas smo se trudili, da s svojim pisanjem koristimo interesom znanosti in znanstvenikov. Večinoma smo bili pri tem deležni tudi podpore vodstev Dela. Pravi čudež je že to, da je znanstvena priloga obstala več kot tri desetletja, vse do danes. Upam in želim, da bo tako tudi v prihodnje.

Jasna Kontler - Salamon 



\section{Znanstvena politika od znotraj in s strani Primož Južnič}

Spremno besedo pogosto začnemo s kakšno frazo, na primer, da gre za izjemno, zanimivo ali aktualno knjigo. Tudi sam se težko izognem takemu začetku, saj bi za knjigo Slovenska znanost: akademska igra ali adut družbenega napredka lahko uporabil vse tri pridevnike. Tematika je težavna; znanost je zapletena in večini ljudi pogosto precej odtujena dejavnost. To je tudi največji paradoks znanosti. Četudi praktično vse, kar danes predstavlja napredek človeštva ter kvaliteto življenja in bivanja, temelji na izsledkih in rezultatih znanosti, se večina državljanov vanjo ne poglablja oziroma jo jemlje kot nekaj samoumevnega.

Franci Demšar in Jasna Kontler - Salamon sta združila moči in vsak na svoj način odstrla nekaj dejstev o znanosti v Sloveniji. Franci Demšar, dolgoletni uspešni raziskovalec, ki je v drugem delu svoje kariere postal ustvarjalec in izvrševalec znanstvene politike, je prispeval svoje znanje in izkušnje $\mathrm{z}$ obeh bregov. Nekaj njegovih dosedanjih knjig (Demšar 2013; Demšar in Zatler, 2018) so slovenski bralci in javnost dobro sprejeli. Jasna Kontler - Salamon, ki je desetletja sistematično in nepristransko novinarsko poročala o slovenski znanosti, je knjigi dodala še ta pogled.

Knjiga govori o razvoju slovenske znanosti in predvsem znanstvene politike v zadnjih desetletjih. Izogne se ideološkemu označevanju (pred in po samostojnosti) in nam prepričljivo pokaže, da gre na tem področju za sistematičen razvoj. Sedanja znanstvena odličnost in izjemen položaj slovenske znanosti - po vseh kazalcih, ki to merijo in nas primerjajo $\mathrm{z}$ mednarodno znanostjo - sta rezultat prizadevanj različnih generacij znanstvenikov pa tudi tistih odločevalcev, če naj uporabim ta izraz namesto slabšalnega "politiki«, ki so razumeli in dojeli, da je vložek v znanstveno raziskovanje vložek v razvoj in bodočnost. Ob tem pa knjiga opozarja tudi na stranpoti, napačne in enostavno slabe odločitve, ki so, žal prepogosto in včasih celo v trenutku, zaustavile ali uničile večletna prizadevanja.

V knjigi je je nekaj tematik, ki jim je mogoče dosledno slediti in ki 
kažejo, zakaj je znanstveno raziskovanje pomembno in kako se to kaže v praksi. Da je znanost sistematično pridobivanje novega znanja, je sicer res, toda kako se to izraža? Zato je opominjanje avtorjev, kako pomembna je znanost za izobraževanje in usposabljanje novih strokovnjakov, vredno posebne pozornosti. Desetletja star program »novi oziroma mladi raziskovalci« je bil pravi odraz razumevanja, kako pomembna je za družbo odlična usposobljenost strokovnjakov.

Ne morem zaobiti še ene pomembne tematike, znanstvene odličnosti. Gotovo gre za občutljivo področje - nihče ni rad ocenjevan, ne nazadnje smo že kot šolarji pogosto prepričani, da so ocene našega znanja in sposobnosti krivične. Znanstveniki smo seveda še toliko občutljivejši in ocenjevanje našega dela nam je lahko neprijetno in odvečno. Toda zagotovo je nujno!

V vsaki državi se odločevalci sprašujejo, s kakšnim uspehom so bila uporabljena sredstva, ki so bila vložena v znanstveno raziskovanje. Seveda imamo različna širša merila: že omenjeno število vrhunsko usposobljenih raziskovalcev, gospodarsko rast ali kakovost življenja. Toda čeprav vemo, da je tudi kakovost življenja odvisna od znanosti, jo le težko neposredno povežemo z njo. V majhni državi, kot je naša, tudi težko ocenjujemo veljavo, vrednost in odličnost posameznih raziskovalcev ali raziskovalnih skupin. Za to imamo vrsto uveljavljenih meril in kazalnikov (običajno imajo skupno oznako bibliometrijska/-i), ki pokažejo, kakšna je znanost in s tem znanstvena politika določene države $v$ okviru svetovnih primerjav. Po teh kazalnikih se je Slovenija na lestvicah vidno povzpela in trenutno smo, seveda glede na število prebivalcev, celo $\mathrm{v}$ vrhu $\mathrm{E} \mathrm{U}$ in sveta.

Do take ravni ni bilo enostavno priti, pot, ki je sem vodila, pa je opisana v knjigi. Sam znanstveno politiko spremljam, odkar sem začel profesionalno kariero, in to $\mathrm{v}$ različnih vlogah, kot raziskovalec in kot strokovni sodelavec v ustanovah, ki usmerjajo raziskovalno politiko. Zato sem si ob tej priložnosti dovolil napisati še krajše besedilo, ki opisuje na podoben način kot ta knjiga, ki se sicer posveča znanosti nasploh razvoj enega od segmentov raziskovalne infrastrukture, dostop do mednarodne literature, področja, na katerem delujem.

\section{Razvoj sistema sofinanciranja mednarodne literature in baz podatkov}

"Najbolj pogosti argumenti proti omejitvam (dostopa do) tuje strokovne in znanstvene literature so strokovni in znanstveni. Ker ni informa- 
cij, nastaja nepojmljiva strokovna in znanstvena škoda. Naša znanost in strokovnost zaostajata, ker nimamo stika $\mathrm{z}$ aktualnimi svetovnimi tokovi. Znanost bo tako teže prevzemala naloge, ki jih pričakujemo od nje ... (Južnič, 1984). Besede, napisane pred skoraj 35 leti, še danes zvenijo aktualno in bodo tako zvenele še desetletja. In to kljub temu, da so se pogoji, oblike in načini dostopa do uporabe znanstvene literature oziroma informacijskih virov $\mathrm{v}$ znanosti, kot temu danes rečemo, še kako spremenili in se še spreminjajo. Znanost je temelj tistega, čemur danes rečemo produkcija (novega) znanja. Znanstveniki/raziskovalci delujejo na podlagi znanja, ki je zbrano $\mathrm{v}$ okviru aktualne znanstvene paradigme.

Znanstvenik uporablja »informacije«, ki jih je pridobil s svojim raziskovalnim delom, skupaj z informacijami, ki jih je pridobil iz dela (praviloma objav) drugih znanstvenikov in raziskovalcev, kot dokaz, s katerim utemeljuje in podpira svoje ugotovitve. S tem šele dopolni svoj prispevek k nekemu splošnemu znanstvenemu znanju. Prispevek posameznika k temu znanju je končan šele takrat, ko drugi znanstveniki in raziskovalci sprejmejo njegove ugotovitve kot dejstva.

Ključnega pomena za informacijski proces $\mathrm{v}$ znanosti, ki ga pogosto označimo kot proces znanstvenega informiranja in komuniciranja, je medij, ki ga omogoča, oziroma način, po katerem poteka. Proces se je praviloma odvijal in se še vedno odvija $z$ rednim in natančnim spremljanjem objavljenih znanstvenih rezultatov, ki so pogoj za doseganje novih znanstvenih rezultatov in dosežkov. Dejstvo, da danes vse bolj uporabljamo pojem dostopa in vse manj govorimo o nakupu, samo odraža spremembo oblike in uporabe, nikakor pa ne vsebine in pomena. Kljub vsem spremembam, ki so danes aktualne in predstavljajo nove rešitve - v mislih imam v prvi vrsti »odprti dostop« (OA, open access) -, so mehanizmi ostali podobni. Dostop do najkakovostnejših informacijskih virov, brez katerih seveda ni resne in kakovostne znanosti, je običajno plačljiv, sredstva za ta namen pa praviloma prispevajo posamezne raziskovalne organizacije in ustanove.

Zagotavljanje tovrstnih sredstev je v Sloveniji urejeno nekoliko drugače, kot je običajno. Del sredstev sicer res prispevajo, tako kot večinoma drugje po svetu, posamezne raziskovalne organizacije in ustanove, večji del pa sofinancira država neposredno iz sredstev, ki so za to namensko določena. V pričujoči knjigi je odlično pojasnjeno, zakaj je tako in zakaj ustanovam ne bi namesto tega preprosto namenili dodatnih sredstev. Zato, ker imajo slovenske akademske ustanove precej različne 
standarde. Smiselno je torej, da vsem omogočimo enak dostop in možnost uporabe, ki je, kot smo že omenili, pomemben za doseganje dobrih rezultatov.

Takšno sofinanciranje ima že dolgo, več kot tridesetletno tradicijo. Država je specialnim, visokošolskim in univerzitetnim knjižnicam začela sofinancirati nabavo mednarodne (tuje) znanstvene literature in baze podatkov v zgodnjih osemdesetih letih prejšnjega stoletja. Takšen sistem sofinanciranja osnovnih informacijskih virov za raziskovalno dejavnost in visokošolski študij se je v Sloveniji vzpostavil pravzaprav iz nuje. V sedemdesetih letih je bila takratna Jugoslavija zaradi zgrešene ekonomske politike in enormnega zadolževanja v veliki finančni stiski, ki se je odražala v t.i. pomanjkanju »deviz«, zaradi česar je država med drugim ukinila uvoz tuje znanstvene literature. Navedek na začetku tega besedila je bil moj protest oziroma opozorilo mladega vodje ene od osrednjih visokošolskih knjižnic o posledicah tega ukrepa. V knjigi je navedena duhovita ilustracija tistega časa: če starejše raziskovalce vprašate, po čem so si zapomnili tedanjega predsednika republiškega izvršnega sveta Janeza Zemljariča, vam bodo odgovorili, da po enoletni luknji na policah znanstvenih revij. Da, na srečo samo enoletna luknja, saj so imeli takratni raziskovalci dovolj moči, slovenski politiki pa dovolj razuma (edini v takratni Jugoslaviji), da so se devize »čudežno« našle in se je financiranje sistemsko uredilo v okviru Raziskovalne skupnosti Slovenije (RSS).

RSS je bila do svoje ukinitve leta 1989 glavni financer raziskovalne dejavnosti v Sloveniji in je skrbela tudi za sofinanciranje nabave mednarodne ali »tuje« literature, kot smo ji takrat rekli. Njena ukinitev je bila žal le ena od nerazsodnih odločitev poslavljajočega se političnega sistema, saj se je R S $\mathrm{z}$ leti delovanja oblikovala v forum, kjer so se srečevali in vzajemno sodelovali (prek svojih predstavnikov) država, raziskovalci in industrija ter drugi uporabniki raziskovalnih rezultatov.

Po ukinitvi RSS je sofinanciranje nabave mednarodne literature prevzelo resorno ministrstvo. Sčasoma se je pokazalo, da je bil to velik korak nazaj. Šele z ustanovitvijo Javne agencije za raziskovalno dejavnost Republike Slovenije (A R R S), ki začne z delom leta 2004 in v naslednjem letu prevzame tudi sofinanciranje tega področja, se obravnavanje tega področja spet obrne $\mathrm{v}$ pravo smer.

Sofinanciranje mednarodne literature v Sloveniji lahko razdelimo na tri različna časovna obdobja, ki se med seboj razlikujejo glede na način, obseg in oblike sofinanciranja, kot bomo videli v nadaljevanju. 


\section{Prvo obdobje (1985-1995)}

Leta 1985 preneha upadati uvoz tuje (mednarodne) znanstvene in strokovne literature. Kot smo že omenili, takratno slovensko politično vodstvo, edino v takratni Jugoslaviji, »čudežno« najde devize. R S S sofinancira nabavo sprva samo trem univerzitetnim knjižnicam, kar se ne pokaže kot najboljša rešitev, zato sofinanciranje razširi na osrednje knjižnice za posamezna znanstvena področja, ki koordinirajo nabavo in $\mathrm{s}$ tem tudi dostop. Tako se zasnuje osnova sistema, ki omogoča stabilna sredstva in preglednost ter uravnoteženost posameznih ved. Stabilnost sredstev pomeni, da se njihova višina usklajuje $\mathrm{z}$ rastjo cen mednarodne znanstvene literature.

\section{Drugo obdobje (1995-2004)}

Že uveljavljen sistem se v tem obdobju žal začne rušiti, pojavi se močno drobljenje sofinanciranja, zelo se poveča število prejemnikov. Prejšnjo koordinacijo vse bolj nadomešča načelo »vsakemu nekaj«, brez resne usmeritve. V letih od 2000 do 2003 so se zaradi tako ustvarjenega kaosa sredstva občutno zmanjšala, leta 2002 pa so jih nameravali celo ukiniti - v predlogu proračuna za leto 2002 takratnega resornega ministrstva bi jih zaman iskali. Kratkovidna uradniška odločitev je dosežek dvajsetletnega truda, da bi imeli slovenski raziskovalci urejen dostop do tako pomembnega dela raziskovalne infrastrukture, preprosto zbrisala s seznama. Za nameček so bila sredstva, paradoksalno, ukinjena kljub temu, da je celo v Zakonu o knjižničarstvu, sprejetem leto prej (2001, 55. člen), zapisano:

Za podporo usklajenemu razvoju knjižnične dejavnosti prispeva država po postopku, ki je določen s področnim zakonom, proračunska sredstva za:

- nabavo tujega knjižničnega gradiva v nacionalni, visokošolskih in specialnih knjižnicah na podlagi kriterijev, ki jih določi za posamezno področje pristojni minister [...]

A na srečo tudi uradniška samovolja ni bila vsemogočna. Najvišji predstavniki raziskovalne skupnosti so osebno posredovali pri takratnem ministru in namenska sredstva, četudi prepolovljena, so se vrnila $\mathrm{v}$ proračun ministrstva.

Dogajanje je posledica tistega, na kar opozarja pričujoča knjiga - da financiranje znanosti ne more in ne sme biti v pristojnosti izključno ministrstev in uradnikov. 


\section{Tretje obdobje (2004-)}

Sredstva za mednarodno literaturo se prvič povečajo leta 2004, takrat še $\mathrm{v}$ okviru proračuna resornega ministrstva, povečanje pa je namenjeno sofinanciranju konzorcijev (e B S C O, Science Direct, C A B-F S T A). V Sloveniji smo $z$ nabavnimi konzorciji, ki so bili takrat v razvitih državah že uveljavljena oblika nabave, začeli s precejšnjo zamudo. Eden od glavnih razlogov je bil zastarel sistem sofinanciranja, razdrobljenost, nepreglednost in "vrtičkarstvo«.

Pravi institucionalni okvir za nujne spremembe je bil postavljen leta $2004 \mathrm{z}$ ustanovitvijo Javne agencije za raziskovalno dejavnost republike Slovenije (A R RS). Agencija je sprejela jasne kriterije za sofinanciranje in delitev sredstev in od leta 2005 vsako leto objavi Javni razpis za sofinanciranje nakupa mednarodne (tuje) znanstvene literature.

Za področje mednarodne literature in baze podatkov je oblikovala tudi strokovno telo, ki si prizadeva, da bi imeli raziskovalci v Sloveniji čim boljši dostop do informacijskih virov. Strokovno telo sestavljajo strokovnjaki za področje izgradnje knjižničnih zbirk in dostopa do informacijskih virov, ki zastopajo vse znanstvene vede. To je pomembno, saj se med seboj tako kot same raziskave razlikujejo tudi informacijski viri zanje.

\section{Glavni dosežki sistema sofinanciranja mednarodne literature Jasna metodologija ocenjevanja in javna objava rezultatov razpisa}

Razpis je objavljen vsako leto, prošnje pa se obravnavajo glede na sprejeto metodologijo, ki se je $\mathrm{z}$ leti spreminjala in posodabljala.

\section{Model 4 + 4 (oz. celotno področje) za vse konzorcije}

Nabavni konzorciji so postali glavna oblika organizacije dostopa do informacijskih virov. $S$ tem smo se praktično povsod v Sloveniji izognili t. i. nacionalnim konzorcijem, pogajanja o ceni in dostopu pa prepustili tistim, ki se na to najbolje spoznajo, knjižničarjem, kar je med drugim prineslo tudi ugodnejše cene. Veliko večino konzorcijev koordinirajo na Centralni tehniški knjižnici, manjši del pa v Narodni in univerzitetni knjižnici. ARRS je kot glavni sofinancer vztrajala, da morajo biti za sofinanciranje izpolnjeni pogoji enakega dostopa za vse univerze in javne raziskovalne zavode (vsak konzorcij mora biti sestavljen iz najmanj štirih univerz in štirih J R Z, razen če gre za ožja znanstvena področja). 


\section{Elektronski dostop, spremljanje uporabe, povezava med različnimi viri}

V tem obdobju se je od klasične nabave tiskanih znanstvenih revij prešlo k elektronski in $h$ konzorcijski nabavi. Konzorciji so postali prevladujoči način organizacije dostopa do mednarodne znanstvene literature in ne več dodatek, kot je bilo od začetka. Prehod od individualnih naročil h konzorcijem je potekal istočasno kot prehod od tiskanih k elektronskim revijam.

\section{Dostop do večjega obsega informacijskih virov}

Leta 2009 so se sredstva za nakup tuje znanstvene literature povečala za $44 \%$ glede na leto 2008 , od tega se je delež za delovanje konzorcijev povečal za $75 \%$. Do podobnega premika je prišlo tudi leta 2018. Agencija za raziskovalno dejavnost je v letu 2009 za sofinanciranje nakupa oz. dostopa do tuje znanstvene literature in baz podatkov namenila 3,52 milijona evrov proračunskih sredstev, medtem ko je v letu prej za ta namen razdelila 2,2 milijona evrov. Leta 2017 je bilo razdeljenih 3,3 milijona, leta 2018 pa 3,9 milijona evrov. Slovenski raziskovalci imajo tako neomejen dostop do vseh najboljših znanstvenih revij oziroma informacijskih virov na svojih področjih. Ta je organiziran tako, da je za uporabnike popolnoma nemoteč in enostaven. Raziskovalci imajo namreč zaradi velike zahtevnosti in intenzivnosti svojega dela zelo malo časa, kar takšen sistem dostopa upošteva.

Pri sistemu nabave so se pojavljale tudi posamezne težave, ki so bile pri delu včasih spodbuden izziv, še pogosteje pa so delo žal ovirale. Najbolj žalostno je to, da je do takšnih težav pogosto prihajalo pri knjižničarjih, praviloma starejših generacijah, ki novostim v stroki niso utegnile slediti, kar se je kazalo v:

- želji po ohranitvi tiskanih revij;

- nerazumevanju pomena nabavnih konzorcijev;

- nezadovoljstvu z vsakoletnim razpisom.

Rezultati raziskav na področju bibliotekarske in informacijske znanosti v svetu in Sloveniji že več kot desetletje jasno kažejo, da raziskovalci razen nekaterih izjem (na nekaterih humanističnih področjih) tiskanih revij ne potrebujejo več. Poleg tega jih ne zanima, kako je organiziran dostop, pomembno je le, da je enostaven. Nabavni konzorciji so se izkazali kot trenutno najučinkovitejša in najracionalnejša organizacijska 
oblika, ki pa od knjižničarjev seveda zahteva stalno sodelovanje in dogovarjanje. Najbolj nerazumljiv pa je bil odpor nekaterih knjižničarjev do letnega razpisa. Dejstvo namreč je, da je ta spodbudil transparentnost delitve sredstev in tudi občasno povečanje sredstev, knjižničarjem pa zaradi večinoma $\mathrm{v}$ celoti avtomatiziranih prijav in poročil $\mathrm{v}$ okviru sistema сO B IS s, ki jih omogoča izjemna informacijska podpora informacijskega servisa IZU M, ne predstavlja večjih dodatnih obremenitev.

Ob vsem tem pa obstaja še sistemska, lahko bi rekli politična težava. Z vstopom Slovenije v E U je bil skladno z uredbo E U uveden 9,5-odstotni DDV za tiskane in 22-odstotni DDV za elektronske informacijske vire, četudi gre za enake vsebine. Dolga leta smo tako v E U kot v Sloveniji protestirali proti tej direktivi/uredbi in opozarjali na njen nesmisel in tudi nerazvojno naravnanost. Leta 2017 je bil ta nesmisel končno odpravljen in od takrat lahko članice za vse publikacije uporabljajo nižjo stopnjo D D V. Žal v Sloveniji te možnosti nismo izkoristili in nesmisel, da ustanove plačujejo D DV za dostop do mednarodne literature v proračun, iz katerega se financira tudi njihovo delovanje, ostaja nespremenjen. Za vsa sredstva, ki jih A R R S namenja dostopu do mednarodne literature, morajo tako odšteti D DV, ki nanese približno petino prejetih sredstev.

\section{Želje in cilji}

Zato je za vse, ki skrbijo za nemoten dostop do informacijskih virov za potrebe znanstvenega raziskovanja, ena glavnih želja in med osrednjimi prizadevanji za bodočnost nedvomno ureditev D DV in s tem jasnejša slika sredstev, ki jih v Sloveniji potrebujemo za dostopanje do teh virov. Ustrezno sofinanciranje dostopa do informacijskih virov $\mathrm{v}$ znanosti je seveda širši cilj, ki ga v zadnjih letih dosegamo, a morda ni odveč pripomniti, da si moramo prizadevati, da ga tudi ohranimo. Dosežek, ki ga je prav tako treba ohraniti, je vrednotenje prijav, in to na transparenten način, saj le tako lahko dobro deluje. Tako vrednotenje najbolj koristi uporabnikom, saj se vsi trudimo, da bi bil dostop do vseh informacijskih virov, ki jih potrebujejo pri svojem delu, čim boljši.

Naslednji velik izziv je povezovanje dostopa do informacijskih virov in skrbi za odprti dostop. Tu moramo biti previdni - odprti dostop nikakor ni nadomestilo za kontinuiran dostop do informacijskih virov $\mathrm{v}$ znanosti. Predvsem pa ni nekaj, kar bi lahko uveljavili takoj in brezpogojno, kot žal pogosto slišimo ali nas o tem prepričujejo nekateri goreči privrženci odprtega dostopa. Govorimo o privržencih, saj odprti dostop 
lahko razumemo ne le kot novo obliko znanstvenega informiranja in komuniciranja, ampak tudi kot (politično) gibanje. Poleg tega pa pomeni tudi nov poslovni model, kar se včasih kar malo pozabi. Ta poslovni model ob nepazljivem in prehitrem vzpostavljanju novih oblik $\mathrm{v}$ resnici pomeni še toliko večje dobičke za velike mednarodne založniške korporacije; torej za tiste, ki z informacijskimi viri že sicer dobro služijo in zaradi katerih se je $\mathrm{v}$ marsičem gibanje za $\mathrm{OA}$ začelo. Tu imam $\mathrm{v}$ mislih zahteve po t.i. »zlatem dostopu«, ki vključuje plačilo avtorjev za odprti dostop. Prehiter skok v novi model lahko pomeni nekaj podobnega, kot je opisano na začetku - težave pri dostopanju do najkakovostnejših informacijskih virov v znanosti. Slovenija se je v zadnjih 25 letih $\mathrm{s}$ številom objav $\mathrm{v}$ najkakovostnejših mednarodnih revijah $\mathrm{z}$ zgolj polovice povzpela kar na dvakratnik evropskega povprečja, $\mathrm{z}$ odmevnostjo znanstvenih člankov pa s tretjine na 150 odstotkov evropskega povprečja. To pomeni, da bi plačilo za objave naraslo, kar bi ne nazadnje lahko zamajalo trenutno zelo uspešen model. 



\section{Pomembnejše okrajšave in kratice}

ARRS Javna agencija za raziskovalno dejavnost Republike Slovenije BDP bruto domači proizvod

Cов ISS (Co-operative Online Bibliographic System in Services) slovenski knjižnični informacijski sistem - hkratna baza za knjižnice in znanstvene publikacije slovenskih raziskovalcev

E K Evropska komisija

E RC (European Research Council) Evropski raziskovalni svet

EU Evropska unija

E U-28 Evropska unija 28 držav (v preglednicah povprečje teh držav)

Eurostat statistični urad Evropske unije. V knjigi je uporabljenih veliko podatkov, ki jih objavlja Eurostatov spletni portal, še posebej iz zavihka Znanost in tehnologija (Science and Technology).

I J S Institut »Jožef Stefan«

J RO javna raziskovalna organizacija (univerze in inštituti, ki jih pretežno financira država - JRZ)

JRZ javni raziskovalni zavod (inštituti, ki jih pretežno financira država)

NZRS Nacionalni znanstveno-raziskovalni svet (ministrstva za znanost)

$\mathrm{R} R \mathrm{D}$ raziskovalno-razvojna dejavnost (tudi $\mathrm{R} \mathrm{R}$ - raziskave in razvoj)

RSS Raziskovalna skupnost Slovenije

PORS Posebna raziskovalna skupnost (program aplikativnih raziskav v RSs)

Scopus najobsežnejša znanstvena bibliografska baza s podatki o citiranju

S I C R I S (Slovenian Current Research Information System) informacijski sistem, namenjen javnemu spletnemu prikazu podatkov iz zbirke oziroma evidence izvajalcev raziskovalne in razvojne dejavnosti

TI A Javna agencija za tehnološki razvoj Republike Slovenije

URP Usmerjeni raziskovalni program (program temeljnih raziskav znotraj RSS)

Wos (Web of Science) najstarejša znanstvena bibliografska baza s podatki o citiranju

ZAMTES Zavod Socialistične republike Slovenije za mednarodno, znanstveno, tehnično, prosvetno in kulturno sodelovanje

ZSA znanstveni svet agencije (ARRS) 



\section{Literatura}

Abbott, A., in Schiermeier, Q. (2014). After the Berlin wall: Central Europe up close. Nature, 515(7525), 22-25.

Acemoglu, D., in Robinson, J. A. (2015). Zakaj narodi propadajo: izvori moči, blaginje in revščine na različnih koncih sveta. Ljubljana: U M C O.

Alkalaj, V., in Baškovič, C. (1990). Znanstveno-raziskovalna in tehnološko-razvojna politika Slovenije: izhodiščno gradivo za razpravo in odločanje o sistemu znanstveno-raziskovalne in tehnološko-razvojne politike, nacionalnem programu znanosti in tehnološkega razvoja, bodočem statusu sedanjih raziskovalnih ustanov, pomoč pri razvoju visokega šolstva. Ljubljana: Republiški sekretariat za raziskovalno dejavnost in tehnologijo.

Arsenjuk, U. (2015). Karierne poti doktoric in doktorjev znanosti. Ljubljana: Statistični urad Republike Slovenije.

Auriol, L., Misu, M., in Freeman, R. A. (2013). Careers of doctorate holders: Analysis of labour market and mobility indicators (O E CD Science, Technology and Innovation Working Papers 2013/o4). Pariz: O E C D.

Bartol, T., Budimir, G., Smrekar, D. D., Pusnik, M., in Juznic, P. (2014). Assessment of research fields in Scopus and Web of Science in the view of national research evaluation in Slovenia. Scientometrics, 98, 1491-1504.

Boh, T. (2006). Comparative analysis of partner councils. Ljubljana: Norface EraNet; Helsinki: Edita Prima.

Christian, D. (2010). The return of universal history. History and Theory, 49(4), 6-27.

Cole, J. R., in Cole, S. (1974). Citation analysis. Nature, 183, 32-33.

Demšar, F. (2010, 8. september). Prilagoditev dinamike in načina izvedbe instrumentov financiranja: odgovor na dopis št. 029-562009/56 z dne 6. 9. 2010 (št. 410-1/2010-2). Ljubljana, A RRS.

Demšar, F. (2013). Transparentnost in skrb za denar davkoplačevalcev. Ljubljana: Mladinska knjiga.

Demšar, F., in Bervar, A. (2010). Tekmovalno financiranje raziskovalne dejavnosti. V N. Trunk Širca (ur.), Model učinkovitega managementa visokošolskega zavoda (str. 51-58). Koper: Fakulteta za management.

Demšar, F., in Zatler, R. (2018). Javna hiša Slovenija. Ljubljana: Mladinska knjiga. 
European Commission. (2012). She figures 2012: Gender in research and innovation. Luxembourg: Publications Office of the European Union.

European Council. (2000). Lisbon European Council 23 and 24 March 2000: Presidency conclusions. Pridobljeno s http://www.europarl.europa.eu/ summits/lis__en.htm

European Science Foundation. (2011a). European peer review guide: Integrating policies and practices into coherent procedure. Pridobljeno s http://archives .esf.org/fileadmin/Public_documents/Publications/European_Peer _Review_Guide_01.pdf

European Science Foundation. (2011b). Organisational evaluation of the Slovenian Research Agency (S RA): Evaluation report. Pridobljeno s http://www .arrs.gov.si/sl/analize/publ/inc/ESH-OrgEvalRepSRA-Dec2011.pdf

Györkös, J., in Novak, T. G. (2016). >30: več kor 30 let programa Mladi raziskovalci. Ljubljana: ARRS.

Južnič, P. (1984). Tuja znanstvena in strokovna literatura. Teorija in praksa, 21(1/2), 155-159.

Južnič, P., Pečlin, S., Žaucer, M., Mandelj, T., Pušnik, M., in Demšar, F. (2010). Scientometric indicators: Peer-review, bibliometric methods and conflict of interests. Scientometrics, 85, 429-441.

Južnič, P., in Santos, P. S. (1993). Letters to the Editors. American Scientist, 81, 311-313.

Komac, M., Bavec, C., Penca, M., Vrenko, E., Semolič, B., in Godina, V. (1994). A science and technology strategy for Slovenia. Bruselj: European Commission.

Kobal, E. (2003). Strast po znanju in spoznavanju: pogovori z velikimi slovenskimi znanstvenicami in znanstveniki. Ljubljana: Ustanova Slovenska znanstvena fundacija.

Kordež, B. (2015). Kam je izginilo deset milijard? Gospodarska gibanja in privatizacija v samostojni Sloveniji. Radovljica: Didakta.

Kristan, T. (2015, 23 november). Znanstvena definicija nasprotja interesov. Delo.

Lucić, L. (2010). Uspešnost mladih raziskovalcev po zaključenem usposabljanju (neobjavljeno diplomsko delo). Univerza v Ljubljani, Ljubljana.

Matekovič, P. (2016). Raziskovalni projekti v pretežno pedagoški in pretežno raziskovalni organizaciji (neobjavljeno magistrsko delo). Univerza na Primorskem: Koper.

Meijenfeldt, F. von (2010). Slovenia: A report of the ER AC Policy Mix Expert Group. Bruselj: European Union Scientific and Technical Research Committee.

Merton, R. K. (1938). Science, technology and society in seventeenth century England. Bruges: St. Catherine Press. 
Mlinar, Z. (2012). Globalizacija bogati in/ali ogroža? Življenjsko okolje v globalni informacijski dobi (2. knjiga). Ljubljana: FDV in SAZU.

Nacionalni raziskovalni program. (1995). Uradni list Republike Slovenije, št. 8.

Novak, P., in Demšar, F. (2012, poletje). The history of funding research \& development in Slovenia. Quark, 49-55.

OE CD. (2012). OECD reviews of innovation policy: Slovenia. Pariz: Avtor.

Računsko sodišče. (2010). Revizijsko poročilo: Uspešnost izvajanja programa Mladi raziskovalci. Pridobljeno s http://www.rs-rs.si/rsrs/rsrs.nsf/I /K2A77DCFAD9F998A9C125772Eoo3Eo9D5/\$file/MRji_RSP.pdf

Reid, A., in Stanovnik, P. (2013). The development of a smart specialisation for Slovenia (A report to the European Commission). Technopolis, Bruselj.

Resolucija o nacionalnem programu za jezikovno politiko 2014-2018. (2013). Uradni list Republike Slovenije, št. 62.

Resolucija o nacionalnem raziskovalnem in razvojnem programu za obdobje 2006-2010. (2006). Uradni list Republike Slovenije, št. 68.

Resolucija o raziskovalni in inovacijski strategiji Slovenije 2011-2020. (2011). Uradni list Republike Slovenije, št. 43.

Science Europe. (2015, februar). Empowering researchers to provide societal value: Towards innovation communities that leverage excellence-focused research (Engineering and Technical Sciences Committee Opinion Paper). Pridobljeno s https://www.scienceeurope.org/wp-content/uploads/2015/o3/ Engitech_Paper_FINAL.pdf

Science Europe in Elsevier. (2013, september). Comparative benchmarking of European and US research collaboration and researcher mobility: A report prepared in collaboration between Science Europe and Elsevier's SciVal Analytics. Pridobljeno s https://www.snowballmetrics.com/wp-content/uploads/ SE_and_Elsevier_Report_Final.pdf

Sitar, S. (1987). Sto slovenskih znanstvenikov. Ljubljana: Prešernova družba.

Slak, M. (2016). Spodbujanje vključitve raziskovalcev v pedagoški proces na univerzah (neobjavljeno magistrsko delo). Univerza v Mariboru, Kranj.

Sorčan, S., Demšar, F., in Valenci, T. (2009). Znanstveno raziskovanje v Sloveniji: primerjalna analiza (2. izd.). Ljubljana: A RRS.

Stanovnik, P., Uršič, S., in Rangu, K. (2015). Spremljanje nacionalne konkurenčnosti Slovenije po metodologiji IMD za leto 2015 (zaključno poročilo). Univerza v Ljubljani, Ljubljana.

Strategija ekonomskih migracij za obdobje od 2010 do 2020. (2010). Pridobljeno s http://www.mddsz.gov.si/fileadmin/mddsz.gov.si/pageuploads /dokumenti_pdf/Strategija_ekonomskih_migracij-2010-2020.pdf

Strategija pametne specializacije. (2015). Pridobljeno s http://www.svrk.gov.si /fileadmin/svrk.gov.si/pageuploads/Dokumenti_za_objavo_na_vstopni _strani/SPS_10_7_2015.pdf 
Svetlik, I. (2016, 9. april). Komu koristita akademska svoboda in avtonomija univerz? Delo.

Škrubej, J. (2013). The cold war for information technology. Houston, Tx: Strategic Book Publishing.

The big questions. (2014). New Scientist: The Collection, 1 (1).

Toš, N. (2016). Vrednote v prehodu X: slovensko javno mnenje 2010-2016. Ljubljana: Fakulteta za družbene vede.

Toyard, M. 1679. An account of the Sieur Bernier's way of flying. Philosophical Collections, 1, 14-18.

Velikonja, J., in Lenček, R. (1995). Who's who of Slovene descent in the United States 1995. New York, NY: Society for Slovene Studies.

World Economic Forum. 2015. The global competitiveness report 2015-2016. Ženeva: Avtor.

Zakon o davku od dohodkov pravnih oseb. (2006). Uradni list Republike Slovenije, št. 33.

Zakon o knjižničarstvu. (2001). Uradni list Republike Slovenije, št. 87.

Zakon o raziskovalni in razvojni dejavnosti. (2002). Uradni list Republike Slovenije, št. 96.

Zakon o zavodih. (1991). Uradni list Republike Slovenije, št. 12.

Zupan, B., Smerke, M., Žnidaršič, J., Kaše, E., Sket, B., Hodalič, A., in Valentinčič, T. (1994). Science in Slovenia. Ljubljana: Ministry of Science and Technology of the Republic of Slovenia.

Zupančič, B. M. (2015, 22 oktober). France Bučar 1923-2015. Pridobljeno s https://siol.net/siol-plus/kolumne/france-bucar-1923-2015-395278 

Od nekdaj sem si želel strniti svoje razumevanje delovanja slovenske znanosti in premisliti njegove glavne pomanjkljivosti, hkrati pa predlagati tudi rešitve. Ker je od mojega vodenja Agencije za raziskovalno dejavnost Republike Slovenije minilo nekaj let, zdaj to lahko naredim s primerne časovne distance in opozorim tudi na tiste dileme, o katerih v prejšnjih vlogah nisem javno razpravljal, saj sem ocenil, da bi to lahko oviralo njihovo reševanje in zato ne bi bilo konstruktivno. Knjigo torej jemljem kot priložnost, da povem vse, kar bi bilo po mojem mnenju smiselno ukreniti.

Franci Demšar

Leta 1988 sem prišla v Delovo znanstveno redakcijo in od takrat pa vse do danes (zadnja leta sicer manj intenzivno) spremljam znanstveno dogajanje. Še zlasti me zanimajo vzgibi in akterji slovenske in evropske znanstvene politike. To je bil tudi eden od dveh ključnih razlogov, da sem se odločila za sodelovanje pri tej knjigi. Z navezovanjem na Demšarjev analitični tekst in zaradi časovne distance se iz mojih komentarjev in drugih novinarskih prispevkov namreč lahko izlušči nova sporočilna vrednost.

Jasna Kontler - Salamon

Založba Univerze na Primorskem www.hippocampus.si

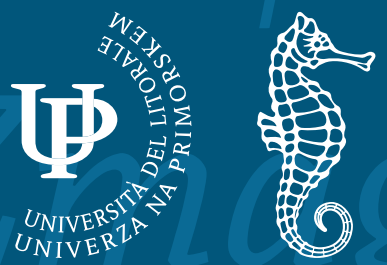

